\author{
Universidade de São Paulo \\ Instituto de Física \\ Instituto de Química \\ Instituto de Biociências \\ Faculdade de Educação
}

\title{
Física e Ficção Científica: \\ desvelando mitos culturais em uma educação para a liberdade
}

\author{
Adalberto Anderlini de Oliveira
}

Orientador: Prof. Dr. João Zanetic

Dissertação de mestrado apresentada ao Instituto de Física, ao Instituto de Química, ao Instituto de Biociências e à Faculdade de Educação da Universidade de São Paulo, para a obtenção do título de Mestre em Ensino de Ciências. 


\section{FICHA CATALOGRÁFICA}

Preparada pelo Serviço de Biblioteca e Informação do Instituto de Física da Universidade de São Paulo

\section{Oliveira, Adalberto Anderlini de}

Física e Ficção Científica: desvelando mitos culturais em uma educação para a liberdade. São Paulo. 2010.

Dissertação (Mestrado) - Universidade de São Paulo. Faculdade de Educação, Instituto de Física, Instituto de Química e Instituto de Biociências.

Orientador: Prof. Dr. João Zanetic

Área de Concentração: Ensino de Ciências

Unitermos: 1. Ensino; 2. Física e Arte; 3. Ficção Científica;

4. Ensino Médio 


\author{
Universidade de São Paulo \\ Instituto de Física \\ Instituto de Química \\ Instituto de Biociências \\ Faculdade de Educação
}

\title{
Física e Ficção Científica: \\ desvelando mitos culturais em uma educação para a liberdade
}

\author{
Adalberto Anderlini de Oliveira
}

Banca Examinadora:

Prof. Dr. João Zanetic (IFUSP)

Prof. Dr. Arnaldo de Moura Vaz da Silva (COLTEC - UFMG)

Prof. Dr. Luís Paulo de Carvalho Piassi (EACH - USP) 

Nome: OLIVEIRA, Adalberto Anderlini de

Título: Física e Ficção Científica: desvelando mitos culturais em uma educação para a liberdade.

Dissertação de mestrado apresentada ao Instituto de Física, ao Instituto de Química, ao Instituto de Biociências e à Faculdade de Educação da Universidade de São Paulo, para a obtenção do título de Mestre em Ensino de Ciências.

Aprovado em:

Banca Examinadora:

Prof. Dr.: Instituição:

Julgamento.:

Assinatura:

Prof. Dr.:

Instituição:

Julgamento.:

Assinatura:

Prof. Dr.: Instituição:

Julgamento: Assinatura: 

À memória de meu querido primo com quem aprendi a arte de viver alegremente João Gabriel Rampin Zenidarci 03/12/1980 - 09/07/2008

Morreste. Veio a notícia Ter com o meu ignorá-la. Velho amigo! Sem perícia Chorei sua sorte impropícia Não há mal senão chorá-la.

Não sabe descrer o forte?

O sábio confia e faz.

Morreste? Falhou-te a sorte.

Não acredito na morte.

Até à vista, rapaz! 



\section{Agradecimentos}

A minha mãe, que fez da minha vida sua razão de viver. Nunca poderei ser mais grato a qualquer outra pessoa.

A minha família, pelo amor, pelos valores, pelo apoio, pela alegria, (...pela mesa cheia de gente e capelettis...), sempre incondicionalmente presentes.

A João Zanetic, que me acolheu, instigou e confiou no meu processo, serei eternamente agradecido. Que agradável é ler sua benévola caligrafia nas entrelinhas de meus textos e ouvir-lhe a leitura pausada e intensa de fragmentos de grandes livros! Sinto-me honrado por ser seu (des)orientando.

Aos professores que, no caminho da vida, desafiaram-me e incentivaram-me à leitura (inclusive emprestando-me ou dando-me livros). Dentre eles, minha especial gratidão a: Marcílio Gomes Jr.; Luis Vitor Martinello; Cibelle Celestino Silva; Wilton S. Dias; Neide L. de Rezende; Cristiano R. de Mattos; além, é claro, de João Zanetic.

Tomando como representantes José da Silva Jr, Gaspar S. Mota Filho, Davi C. M. Offerni, Arthur J. Garcia, José Luís Ortega, Guilherme Ortega, Luís Fernando Gaido e Rogério Massato Inoue, agradeço aos meus amigos de Araçatuba e Bauru, cujas lembranças sempre invadem sorrateiramente minha mente, roubando-me sorrisos desavisados.

Aos meus amigos de São Carlos, pela luta e pela diversão nas vicissitudes da vida acadêmica e extra-acadêmica. São infinitas lembranças saborosas. Um agradecimento especial a Carlos A. M. Morbiolo, Victor R. C. M. Roque, Diogo A. F. Melo e Eslley S. Gonçales, pela força nos estudos, no observatório, no futebol ou no "Tragédia"; a Welton A. Gomes, que me iniciou nos caminhos da filosofia da ciência; e a Rodrigo G. Vieira e Fernando H. P. Luz, pela força também em São Paulo. Sem vocês, nada disso teria sido possível.

Aos amigos de São Paulo: da USP, do grupo de estudos do Zanetic, da Estação Ciência, pela aprendizagem sempre renovada e pelas risadas que certamente ainda ecoarão de tempos em tempos. Pelos ricos diálogos, um obrigado especial a Milton Schivani e Leonardo Crochik.

Aos amigos da Escola Waldorf São Paulo - pais, professores, funcionários e alunos que, com carinho, vivem a chamar-me 'perturbado' (e eu, com carinho, continuarei perturbando). Um obrigado especial à Joana M. Falavina, pelas correções dos inacabáveis rascunhos. 
A Cristiano R. Mattos e a Luis P. Piassi, pelos inestimáveis apontamentos no exame de qualificação, que acabaram redirecionando a essência de nosso trabalho.

A Arnaldo Vaz e novamente a Luis P. Piassi pelas leituras e novos caminhos indicados durante a defesa.

A Clarissa Zamboni Moschin, que me ajudou a "esfarrapar e cerzir" este texto com inúmeras ideias, incontáveis correções, intermináveis diálogos e, principalmente, pelo ilimitado carinho com que me aconchegou nos momentos mais alegres e nos mais difíceis. Deixo aqui minha profunda gratidão e um apaixonado beijo. 


\section{RESUMO}

OLIVEIRA, Adalberto Anderlini de. Física e Ficção Científica: desvelando mitos culturais em uma educação para a liberdade. 2010. 238p. Dissertação (Mestrado em Ensino de Ciências - Ensino de Física) - Instituto de Física, Faculdade de Educação, Universidade de São Paulo, São Paulo, 2010.

Nosso intuito com este trabalho é responder à questão: por que discutir a ficção científica no ensino de física? Buscando autores que a propõem como instrumento pedagógico, encontramos predominantemente estudos que apontam as narrativas como forma de motivar, cativar os estudantes. Após construirmos um castelo teórico baseado em Paulo Freire, Mikhail Bakhtin, Lev Vygotsky, Thomas Kuhn, dentre outros, percebemos que esse motivar significava, na verdade, seduzir - no sentido de convencer o aprendiz de que a ciência precisa ser aprendida. Ou seja, alguns trabalhos acabam, por meio do cientificismo da ficção científica, levando os estudantes a adorar a ciência, persuadindo-os a venerá-la, em uma devoção submissa. Para nós, essa mística fascinação debilitaria suas autonomias frente às opções que esse saber representa e frente aos limites que ele possui. Por conta disso, e embasados na filosofia freiriana, defendemos a ficção científica justamente como uma forma de apresentar e discutir os mitos culturais que recheiam nosso imaginário, delineando nossas concepções de ciência, tecnologia, civilização, relações humanas, etc. Isto é, propomos a decodificação das narrativas deste gênero inerentemente transdisciplinar em um círculo de cultura composto por uma equipe interdisciplinar responsável pela problematização de nossas maneiras de entender e imaginar o mundo - maneiras que revelam ideologias incorporadas culturalmente desde a infância. Problematização seguida pelo estudo da visão de especialistas (sejam eles físicos, filósofos, críticos literários, etc.) e pela aplicação deste conhecimento organizado na elaboração de ações culturais. Indicamos, por fim, um instrumento para analisar os jogos da linguagem científica compartilhados pela ciência e pela ficção científica, com o intuito de esclarecer o pensamento científico, e, consequentemente, a forma como ele influencia as relações entre os sujeitos e entre estes e o mundo. Finalizamos com a exposição de algumas experiências envolvendo a ficção científica nas aulas de física realizadas no ensino médio da escola em que lecionamos.

PALAVRAS CHAVE: Ensino, Física e Arte, Ficção Científica, Ensino Médio 



\begin{abstract}
OLIVEIRA, Adalberto Anderlini de. Physics and Science Fiction: unveiling cultural myths in an education for freedom. 2010. 238p. Dissertação (Mestrado em Ensino de Ciências Ensino de Física) - Instituto de Física, Faculdade de Educação, Universidade de São Paulo, São Paulo, 2010.

Our intention with this work is to answer the question: why to discuss science fiction in physics teaching? Searching for authors that propose it as a pedagogic instrument, we have found predominantly studies that indicate the narratives as a way to motivate, captivate students. After we have built a theoretical castle based on Paulo Freire, Mikhail Bakhtin, Lev Vygotsky, Thomas Kuhn and others, we notice that to motivate means, in fact, to seduce - in the sense of convincing the apprentice that science needs to be learned. That is, some works, using the scientificism of science fiction, leads the students to adore science, persuading them to venerate it, in a submissive devotion. In our view, this mystic fascination would weaken their autonomy in front of the options that this knowledge represents and in front of the limits that it carries. Because of it, and based upon Freire's philosophy, we defend science fiction precisely as a way to present and to discuss cultural myths that fills our imagination, defining our conceptions about science, technology, civilization, human relations, etc. That is, we propose the decoding of the narratives of this genre inherently transdisciplinarity in a culture circle compound by an interdisciplinary team responsible for putting in question our ways to understand and to imagine the world - ways that reveal ideologies culturally incorporated since childhood. Inquiry followed by the study of specialists's vision (such as physics, philosophers, literary critics, etc.) and by the application of this organized knowledge at the elaboration of cultural actions. We indicate, in the end, one instrument to analyze the scientific language games shared by science and science fiction, with the intention of clarifying the scientific thought and, consequently, the way it influences the relation among the subjects and between these ones and the world. We finalize with an exposition of some experiences involving science fiction in physics classes at the high school where we teach.
\end{abstract}

KEYWORDS: Teaching, Physics and Arts, Science Fiction, High School 

$\begin{array}{ll}\text { INTRODUÇÃO } & 19\end{array}$

'Contatos Imediatos do Terceiro Grau' 19

‘A Máquina do Tempo’ 29

Revelando a Linha de Raciocínio de Nossa 'Viagem Fantástica’ 29

CAPítulo I - ESCOLA: o VelHo E O Novo

ou 'FUNDAÇÃO'

I.1 - Paulo Freire - Denunciando um 'Estado de Medo' 34

I.2 - 'Vinte Mil Léguas Submarinas' 41

I.3 - 'Matrix Reloaded' $\quad 42$

I.4 - Práxis: ‘A Fundação e a Terra’ 47

I.5 - Metodologia: Universo Temático - Tema Gerador e Tema Dobradiça 50

\section{CApítulo II - Física É Cultura}

ou 'AdMirável MUNDO Novo'

II.1 - João Zanetic: Física também é Cultura! 58

II.2 - Pout-Pourri Filosófico

II.2.1 - Método Científico ou Mito Científico? 59

II.2.2 - Francis Bacon (1561 - 1626) 60

II.2.3 - David Hume (1711 - 1776) 63

II.2.4 - Karl Popper (1902 - 1994) 64

II.2.5 - Thomas Kuhn $(1922$ - 1996) 67

II.2.6 - Paul Feyerabend (1924 - 1994) 70

$\begin{array}{ll}\text { II.3 - Pout-Pourri Histórico } & 71\end{array}$

II.4 - Física: Instituição Social

II.5 - Ciência: Mitologia Opressora ou Conhecimento Emancipador? 76 


\section{Capítulo III - Realidade, Pensamento e Linguagem}

III.1 - Ludwig Wittgenstein: 'O Homem com Dois Cérebros' 80

III.2 - Mikhail Bakhtin: a Dialética Materialista Socioideológica 85

III.3 - Comparando-os $\quad 92$

III.4 - Lev S. Vygotsky: a Psicologia Sociointeracionista da Aprendizagem 94

\section{CAPítulo IV - SinteTizando}

$$
\text { ou 'Nós' }
$$

IV.1 - Paulo Freire e Mikhail Bakhtin 105

IV.2 - Mikhail Bakhtin e Lev Vygostky 107

IV.3 - Paulo Freire e Lev Vygostky 109

IV.4 - Atando-os em 'Nós' 110

IV.5 - Retomando o Velho e o Novo... e a Liberdade 116

\section{Capítulo V - Ficção Científica: Um Instrumento Pedagógico da EsPeranÇa} $o u$ 'A Cidade e as Estrelas'

V.1 - Estudo da Realidade: A Relação entre a Ficção Científica e seu Contexto

V.1.1 - Breve Histórico da Fiç̧ão Científica Nacional (segundo M. Ginway)

V.1.1.1 - O Primeiro Período (aproximadamente 1960-1970)

V.1.1.2 - O Segundo Período (cerca de 1970-1980)

\section{Capítulo Vi - Organização e AplicaÇão do Conhecimento} ou 'O DIÁlOgO dos MUNDOS' 


\section{CAPítulo VII - FicÇões Científicas}

\section{$o u$ 'TANGENTES DA REALIDADE'}

VII.1 - Brevíssimo Esboço Histórico da Ficção Científica Internacional

VII.2 - Jogos da Linguagem Científica Empregados pela Ficção Científica

VII.2.1 - L. David Allen

VII.2.2 - Umberto Eco

VII.2.3 - Eric Rabkin

VII.2.4 - Darko Suvin

VII.3 - Estratégia para Trabalhar Um Jogo da Linguagem Científica 185

VII.4 - Evitando um Equívoco

\section{Capítulo VIII - Estudo de Caso - Alguns Exemplos Qualitativos}

VIII.1 - Descrevendo o Cenário

VIII.2 - Atividade 1: O Projeto Ciência e Literatura

VIII.3 - Atividade 2: Um Conto e a Tríade Se-Então-Portanto 200

VIII.4 - Atividade 3: Contos Criados pelos Próprios Estudantes 203

VIII.5 - 'Além do Planeta Silencioso'

(IN)CONCLUSÃO

OU 'MATRIX REVOLUTIONS'

Rebobinando o Filme

Fechando o Ciclo 



\section{INTRODUÇÃO}

\section{'CONTATOS IMEDIATOS DO TERCEIRO GRAU'}

Sem dilatar espaço e tempo, arrolemos de imediato alguns trabalhos que nos forneçam um breve panorama das pesquisas envolvendo a ficção científica no ensino de física.

A produção nacional sobre este assunto ainda está engatinhando. Dentre as esparsas pesquisas encontradas, a mais expoente e sistemática é a de L. P. Piassi. Em sua tese de doutorado, verificamos que seu propósito é utilizar a ficção científica como "elemento articulador a partir de onde podemos estabelecer vínculos entre os interesses e motivações dos estudantes em relação a temas científicos e os conteúdos programáticos de ensino" (2007, p. 21). Para realizar essa empreitada, ele parte principalmente das ideias de Georges Snyders, e então argumenta que as atividades pedagógicas devem ser organizadas com o objetivo de levar o estudante a passar da cultura primeira para a cultura elaborada, tendo como ímpeto a satisfação cultural. Isto é, ele defende que a paixão pelo conhecimento leva da efemeridade da alegria simples à perenidade da alegria ambiciosa. A ficção científica entra nessa linha de raciocínio como um canal privilegiado capaz de estimular o interesse dos alunos por conta de sua especificidade enquanto gênero. Especificidade esta que pode ser relacionada a três esferas do ensino de ciências: o conceitual-fenomenológico, o histórico-metodológico e o sócio-político (2007, p. 76).

Para Piassi, a adesão afetiva, o despertar da paixão pelo conhecimento, vincula-se à imaginação e à criatividade - características imanentes à ciência e à arte, e intimamente relacionadas na ficção científica. Por isso ele critica alguns pesquisadores que propõem atividades pedagógicas que se resumem a buscar, nas histórias, erros e acertos conceituais ou distorções da imagem do cientista ou dos procedimentos da ciência. A seu ver, estas abordagens simplistas e superficiais, em vez de entender as necessidades literárias e cinematográficas por trás da construção da narrativa, prendem-se a detalhes e perdem a chance de analisar os processos sócio-culturais que levam à apropriação ficcional do discurso científico. Tentando sanar tal abordagem limitante, ele une a interpretação literal dos elementos da obra aos procedimentos criativos de seus autores por meio de caracterizações que ele denominou elementos contrafactuais. Além dessa proposta, ele cria os pólos temáticos, em que o exame da esfera sócio-política da ficção torna-se mais evidente. 
Voltaremos a esses pólos no capítulo VI. No momento, guardemos que Piassi defende a alegria em aprender e a problematização das expectativas sociais em relação à cultura técnicocientífica; isto é, a postura crítica que se estende à compreensão de questões sócio-culturais e não se limita à esfera conceitual-fenomenológica - costume saliente no ensino tradicional.

As propostas de Gary Raham (2004) demonstram toda sua inventividade ao escolher algumas histórias e explorar o potencial de suas individualidades. Ele não intenta elaborar um método geral e único de aplicação da ficção científica em sala de aula. Livre dessa preocupação, sustenta um pragmatismo bem delimitado, cunhando inúmeras atividades excepcionais para instigar a criatividade do aprendiz. Por outro lado, não aprofunda questões epistemológicas e, na sequência dos capítulos de seu livro, ele reconta a história da ciência de forma tão cumulativa e linear, evitando suas vicissitudes e idiossincrasias, que fica difícil descobrir se ele ignora as preocupações gnosiológicas ou se simplesmente acredita que elas são deletérias para a prática pedagógica.

Talvez pela popularidade e maior produção de obras de ficção científica na Inglaterra e nos Estados Unidos, existe também mais pesquisa sobre o uso pedagógico desse gênero cinematográfico-literário em língua inglesa. Em sua ótima capacidade de síntese, Piassi (2007; PIASSI; PIETROCOLA, 2007c, 2008) aborda vários artigos nessa língua sobre o assunto. Para evitar uma redundância desnecessária, apontamos apenas o trabalho de Raham (que é bastante criativo e que não havia sido mencionado), e vamos discutir algumas pesquisas em língua espanhola.

S. Palacios, avaliando as aulas tradicionais em que os estudantes parecem cada vez menos motivados, considera preocupante o analfabetismo científico revelado inclusive nos meios de comunicação (como vemos, os problemas com a educação científica não são exclusivos do Brasil). Assim, ele propõe o poder atrativo da ficção científica como um recurso para motivar o amor pelo conhecimento - com o propósito de divulgar, transmitir e ensinar a Física e as outras ciências (2005, p. 17). As atividades que ele descreve, em geral, tendem para o reducionismo criticado por Piassi, pois visam apenas "aprender com os erros" (2007, p. 108) e acertos conceituais das obras. E, pior, seu objetivo é combater o "efeito pernicioso das ideias previamente concebidas" (2007, p. 108). Nós já pensamos dessa forma e mostraremos no capítulo III como mudamos de postura após o contato com o trabalho de Lev Vygotsky.

Gómez também apresenta um trabalho voltado basicamente para questões conceituais, com o objetivo de conseguir que "os alunos desenvolvam a capacidade de relacionar conceitos que aparecem na leitura com os conhecimentos adquiridos previamente em classe" (2008, p. 302). Sua preocupação se direciona a interesses, necessidades e 
características dos alunos, intentando, por meio da ficção científica, tornar o processo de ensino-aprendizagem mais atrativo, ameno e acessível.

Os vários trabalhos de F. Borrás não fogem a isso. Seu objetivo é facilitar o processo de aprendizagem utilizando a ficção científica, as narrativas policiais e obras afins, para "perseguir a motivação dos alunos" (2005b, p. 80) - principalmente porque elas podem ressoar nos anseios dos adolescentes, revelando suas concepções prévias, permitindo a atuação do professor para derrubá-las (2006, p. 272). Borrás (2008b) também mapeia as imprecisões que envolvem a imagem do cientista (o gênio solitário estereotipado em jalecos brancos, óculos, etc.) e o método científico (normalmente empiro-indutivista) - apontando algumas narrativas que não cometem tais equívocos. Ele supõe ainda que séries televisivas, por serem criativas e divertidas, combatem a desmotivação ao estimular a participação dos estudantes, permitindo, nesse ínterim, "engatar" o alunado "ao carro da Ciência” (2005a, p. 376).

Carmen Retamosa contrapõe a ficção científica às aulas que se resumem à resolução de exercícios de livros didáticos. Verificando que, dentre várias práticas educativas inovadoras, os livros de divulgação científica são um caminho que extrapola a leitura para além dos livros-texto, ela argumenta que enfrentar a leitura com mais ambição, abrangendo a ficção científica, resulta em bons frutos. Dentre esses frutos, além dos usuais “jogos dos sete erros", ela ainda indica que, por meio da leitura da ficção científica, é possível observar como evoluiu a visão da sociedade sobre a ciência e a tecnologia (2005, p. 275). Apesar de ela não aprofundar tal assunto, nesse ponto concordamos plenamente com ela (como veremos do capítulo V em diante).

O pesquisador colombiano Carlos Cuartas, em meio a preocupações voltadas à bioética, afirma que "a literatura de ficção científica é um recurso pedagógico valioso para a formação da consciência ética em consonância com o modo científico de ver o mundo" (2007, p. 92). Ele defende a ficção científica contra aqueles que a consideram baixa literatura ou mero escapismo, ainda que distinga a existência de poucas obras dignas dentre muitas vulgares - algo que, segundo ele, ocorre em qualquer gênero literário. Mais importante, citando Umberto Eco, ele reconhece que, sem um olhar atento, ela se torna um "manual de devoção da civilização industrial" (2007, p. 93).

No fundo, para que a ficção científica supere o marasmo diagnosticado por Eco, precisa-se de um precavido dirigismo cultural - como ele o chama -, quer dizer, a projeção de ações culturais realmente democráticas, feito possível se, e somente se, acredita-se que é factível uma cultura democrática, se não se abriga a secreta persuasão de que a cultura é um feito aristocrático, e de que, ante a república dos homens cultos, ante os aristocratas do espírito, se erguem massas incorrigíveis e irrecuperáveis, para as quais, por acaso, só 
cabe preparar uma subcultura (a chamada cultura de massas) para logo criticar seus modos e efeitos (CUARTAS, 2007, p. 93, tradução livre).

Com certas ressalvas a eventuais interpretações que o uso do termo dirigismo possa desencadear, podemos afirmar que, com Cuartas, finalmente encontramos um autor com quem alinhamos algumas reflexões sobre a estrutura social e escolar, e seu reflexo na ficção científica e seu uso pedagógico. Ele aponta (como defenderemos mais longamente nos próximos capítulos) que o sistema educativo muitas vezes funciona como uma "castração mental e espiritual" (CUARTAS, 2007, p. 94). Assim, para ele, a questão da motivação ganha algo de profundidade em relação aos outros pesquisadores, pois estimular não é seduzir, mas discutir os valores que perpassam a cultura e influenciam essa castração. Isso inclui a física, uma vez que ele reconhece a ciência como construção humana e que, por isso, ela "não se desconecta do axiológico" (idem, p. 101). Ele cita J. Reyes ${ }^{1}$ :

Os gêneros de ação chegam com facilidade ao jovem leitor por sua concretude e o manejo privilegiado do suspense, porém superam tal nível imediato ao suscitar revisões existenciais e conceituais de importante transcendência. Não são fantasias baratas para espíritos banais em busca de evasão. De fundo, manejamos a hipótese de que cada gênero (terror, policial, ficção científica) tem uma sustentação epistemológica que estimula o crescimento da percepção cultural e existencial do jovem leitor. Sempre se pode querer mais do que melhor se compreende, e é bom aprender a querer nossos medos, nossos enigmas e nossas ilusões de um amanhã melhor (REYES apud CUARTAS, 2007, p. 94, tradução livre).

Ainda mencionando Reyes, ele destaca que os protagonistas das grandes obras de ficção científica, longe de serem medíocres ou deixarem crises sem solucionar, nos brindam com "modelos de atuação e gestão éticos". Isto é, por um lado, as histórias passam uma imagem positiva de homem, com qualidades tais como: inteligência, nobreza, intrepidez, moderação, realismo, generosidade e rebeldia; e, por outro, muitas vezes os protagonistas são "representações das grandes falências da humanidade" (CUARTAS, 2007, p. 95). Com isso, pode-se colocar em discussão como cada indivíduo pode assumir sua própria humanidade.

O contexto antropológico e sociológico da ficção científica, além do estímulo à imaginação ou o assombro científico, comunica no fundo um perfil de humanidade por afirmação ou exclusão crítica, feito que confere a tal literatura um elemento formativo valioso (CUARTAS, 2007, p. 95, tradução livre).

Somando isso à intenção explicitamente pedagógica de alguns autores - como a "divulgação científica" de Júlio Verne e Isaac Asimov -, ele argumenta que a paixão pelo conhecimento é a riqueza extraordinária de que não podemos nos abster ao trabalhar com a

\footnotetext{
${ }^{1}$ REYES, J. R. Teoría y didáctica del género ciencia ficción. Bogotá: Magisterio, 2001.
} 
ficção científica. Cuartas finaliza seu artigo com breves indicações de como aproveitar tal gênero em sala de aula, incluindo momentos de análise de obras e momentos de criação de narrativas por parte dos aprendizes. Ele assinala que, nessas atividades, cria-se um ambiente interdisciplinar onde se evita a "fragmentação nefasta em múltiplos campos de especialização" e, concomitantemente, alimenta-se a postura democrática ao aproximar da educação formal uma cultura que não se reduz à cultura aristocrática (2007, p. 103).

Olhando esses artigos em língua espanhola, vimos propostas prioritariamente lúdicas. Foi interessante notar que mais de um pesquisador afirmou que "os alunos não eram obrigados a fazer aquilo que não queriam” (GÓMEZ, 2008, p. 305; PALACIOS, 2005, p. 21). Pelo curto tamanho dos artigos, fica difícil dizer se tal tendência desses autores (não sabemos dizer se é uma característica atual da educação espanhola) não comete a antiga confusão entre liberdade e licenciosidade (FREIRE, 1996, pp. 49:50). Como veremos, nossa visão de liberdade não é a que subentendemos em frases como essas. Ademais, muitos deles propõem a ficção científica como uma forma de combater o mito de que entender ciência é difícil, esperando que ela ensine divertindo, estimulando uma postura positiva frente ao conhecimento científico. Porém, eles se apegam à ideia de que aprender ciência é necessário porque vivemos em um mundo cada vez mais científico e tecnológico. Para nós, tal visão traz implícita a ideia de que não resta outra postura ao aluno a não ser tentar "pegar o bonde da ciência" andando (para usar a imagem de Borrás), e buscar sentar na janela para se maravilhar com aquilo que ele nos mostra em seu caminho. Neste caso, os alunos seriam meros passageiros. Para nós, aprender "porque o mundo é assim mesmo" é se prender a esse mundo, e não libertar ou debater possibilidades de emancipação e reformulação desse mundo.

Em outras palavras, subentende-se nesses autores o seguinte: o aluno precisa estudar ciência porque nossa sociedade é muito científica e tecnológica. Isso beira o fatalismo, pois insinua que a sociedade é, não que ela está. Só quando ela está, ela pode mudar. Por isso preferimos inverter a ordem das palavras daquela afirmação, tornando-a uma indagação: por que nossa sociedade precisa ser científica e tecnológica? E essa não é uma pergunta que cabe ao professor responder solitariamente. Ela deve ser dialogada com os alunos, pois que, senão, o bonde vai continuar desgovernado, ou melhor, sob o governo de poucos, enquanto - como cantava Renato Russo (1986):

...nas escolas as crianças aprendem a repetir a música urbana.

Apresentar a ficção científica como uma forma de entretenimento que serve como uma "via de aproximação" à cultura científica supõe que essa cultura está distante dos alunos, 
que não existem questões relativas à ciência incutidas em nossas mentes, delineando-nos a forma de pensar. Essa ideia se sustenta sob a visão de que o aluno deve negar suas errôneas e descartáveis concepções prévias e se dirigir pela trilha já desbravada pela "correta postura científica" - nesse caso, a ficção científica seria um veículo agradável para percorrer esse percurso. Agindo assim, em vez de permitir ao estudante emergir e fazer escolhas, utiliza-se a ficção científica como uma sereia que seduz o jovem a afundar-se ainda mais no mar tecnocientífico. Nós, pelo contrário, desejamos que a ciência não seja apresentada apenas como algo que liberta e apraz, pois que ela também aprisiona e oprime. Portanto, mais do que perceber que outras pessoas sentem o mesmo encanto pelos buracos negros ou a mesma aversão pelas bombas atômicas, o ato de compartilhar medos e maravilhamentos não pode permanecer em um nível de percepção inoperante, conformista, que continua se sentindo impotente frente a uma realidade supostamente inabalável, pressupondo que, "hoje em dia, é indiscutível a importância da ciência...” (BORRÁS, 2008a, p. 79). É justamente a "discutibilidade" da realidade que deve guiar as preocupações pedagógicas. Para nós, os atos genuinamente educativos são aqueles que influenciam nossa postura frente à vida, impulsionando-nos a pensar e agir de modo diferente se comparado à postura fatalista e acomodada.

Esclarecendo. Uma coisa é fato: concordamos todos que a monotonia impingida sobre os alunos pelo ensino tradicional deve ser mudada. Apenas diferimos na concepção de motivação. Isso não quer dizer que nos opomos às ideias que propõem a ficção científica como um combate ao tédio imbecilizante que domina muitas de nossas aulas. Na verdade, cremos que aquilo que apresentaremos pode ser encarado como um complemento a essa perspectiva. Estes autores defendem a motivação na perspectiva de uma alegria em aprender. Nós não negamos isso. Apenas tentaremos aprofundar essa convicção em um sentido: o de que a motivação pode ser decorrente também de uma alegria (ou indignação) em aprender aquilo que nos aprisiona.

Voltemos às pesquisas em língua portuguesa. Os portugueses Pedro Reis e Cecília Galvão (2006) realizam uma análise qualitativa do enredo de narrativas de ficção científica escritas pelos próprios alunos, buscando diagnosticar suas concepções sobre: as características dos cientistas; a atividade científica; e, as interações entre ciência, tecnologia e sociedade. Para aguçar essa análise, eles efetuam entrevistas semi-estruturadas com os estudantes. No fim, concluem que os jovens desconhecem as questões procedimentais e epistemológicas; e, por isso, muitas vezes revelam concepções estereotipadas e deturpadas sobre as características e a atividade dos cientistas. Eles arrematam o artigo indicando possíveis causas dessas 
conclusões, a saber: as práticas de ensino; as imagens de ciência veiculadas pela mídia; e, a ausência de uma crítica a essas imagens nas aulas de ciências.

Já os brasileiros Souza e Gomes-Maluf apresentam a ficção científica como uma forma de unir o imaginário e o racional no ensino de ciências. Concepção que parte da premissa de que a união da ficção com os conceitos científicos serve tanto para desencadear quanto para organizar a aprendizagem. Para corroborar tal visão, os autores realizam um estudo de caso em um curso de licenciatura em ciências biológicas, "trabalhando, como ato ficcional, o imaginário do filme Jurassic Park e, como elemento racional, os conceitos da Biologia Molecular" (2008, p. 272). A coleta de dados sobre o conhecimento dos alunos se deu por mapas conceituais e formulários diagnósticos. Os pesquisadores afirmam que a inserção da ficção científica no ensino pode ser útil para polemizar questões éticas, científicas e sociais; porém, não aprofundam tal afirmação e focalizam suas considerações na aprendizagem conceitual. $\mathrm{O}$ uso do filme em duas turmas em momentos distintos levou-os à seguinte conclusão:

Assim, podemos afirmar que a inserção de filme de ficção científica deve ser efetuada no início das atividades, pois ele serve como um aparato desencadeador da aprendizagem e organizador dos conceitos que serão explorados; enquanto sua inserção após a exploração dos conceitos da disciplina acaba por gerar uma insegurança em relação à validade teórica de seus conceitos. É como se sua inserção ao término das atividades gerasse dúvidas nos pesquisados sobre a validade de seus conceitos, criando-se um obstáculo frente ao conhecimento (GOMES-MALUF; SOUZA, 2008, p. 281).

Nesse sentido, não concordamos com eles, visto que acreditamos ser a dúvida um dos aspectos essenciais do conhecimento científico. Porém, fica difícil tomar essa afirmação de forma tão superficial porque o artigo que eles escrevem baseia-se na concepção epistemológica de Gaston Bachelard e, portanto, eles consideram importante para a ciência não só a continuidade como também a ruptura. Dessa forma, acreditamos que essa proposta não se enquadre nas pesquisas reducionistas criticadas por Piassi.

Contudo, há também produção nacional que se enquadra em sua crítica. Pedrochi e colaboradores, buscando conectar o ensino de ciências às estratégias informais, acabam recaindo na prática reducionista, afirmando inclusive que "serão analisados alguns dos filmes mais clássicos dos gêneros e seus mais clamorosos equívocos (muitos) e acertos (poucos)" (2001, p. 1). Mesmo assim, segundo eles, o uso da ficção científica no ensino é bastante eficaz visto que os filmes muitas vezes demonstram as mesmas concepções espontâneas que os alunos. Isto é, assim como alguns pesquisadores apontados acima, estes também acreditam 
que, identificados os equívocos, o conhecimento científico deve substituir o conhecimento prévio, cotidiano.

O trabalho de Luciano Oliveira (2006) aponta na mesma direção. Ele sugere a utilização do filme Homem Aranha como elemento motivador no ensino da Física e apresenta análises qualitativas e quantitativas de algumas cenas. Ele argumenta que suas aplicações dessas análises em sala de aula sempre levam a discussões muito ricas e que os alunos adoram encontrar as discrepâncias entre as cenas do filme e a realidade.

Luciene Silva e colaboradores (2005) realizam trabalho similar: propõem a ficção científica como forma de motivar o debate científico em torno dos fenômenos físicos identificados pelos alunos em alguns filmes. Para esses pesquisadores, os filmes despertam curiosidades e emoções, além de induzir no telespectador concepções alternativas muitas vezes incongruentes com o conhecimento científico.

Ferreira e co-autores seguem por uma trilha parecida. Indicam que a ficção científica - como um material alternativo para a sala de aula - possibilita apresentar cenários e situações que promovem o debate e o questionamento. Para eles, por meio dela é "possível abordar conceitos físicos de termodinâmica, óptica, eletromagnetismo, relatividade geral e restrita, física quântica, geofísica, astronomia e outras. Neste caso, a discussão das películas pode corroborar - ou refutar - o conhecimento prévio trazido pelos estudantes, quiçá tornando mais significativa a aprendizagem" (2009, p. 6).

O trabalho de Neves e colaboradores, reconhecendo como reducionistas práticas como essa, explora "uma visão construtivista de aprendizagem, onde não é necessário remover as ideias intuitivas dos estudantes" (2000, p. 99). O objetivo deles é, por meio de discussões sobre cenas de filmes de ficção científica, investigar a origem de algumas representações mentais espontâneas de conceitos físicos. Descoberto esse senso comum, eles buscam promover mudanças conceituais amparadas por uma discussão da história da ciência. Por exemplo, assistindo a filmes com guerras espaciais, alguns alunos revelam conceitos sobre o movimento muito próximos aos de Aristóteles. Buscando similitudes entre essas concepções prévias e a evolução conceitual da mecânica, passando por João Buridan e Nicolau Oresme, até chegar a Galileu Galilei e Isaac Newton, os alunos são conduzidos até uma nova compreensão conceitual.

Também pudemos notar em alguns autores pesquisados uma tendência a utilizar a ficção científica para discutir questões éticas. Além do já citado trabalho do colombiano Cuartas, podemos indicar o artigo da norte-americana Anastasia Pease (2009) - que concebe a ficção científica como uma oportunidade de exercitar a imaginação moral -, e o da brasileira 
Lêda Mendonça (2009-2010) - que utiliza trechos de ficção científica para contextualizar e debater questões éticas relativas à pesquisa científica. Normalmente esses trabalhos unem-se a preocupações socioambientais. É o caso do artigo de Piassi com Santos e Vieira (2008) e do texto de Carlos Machado (2008). É comum tais trabalhos revelarem preocupações similares às de Nishitani e Silva:

Uma consciência que forneça embasamento ao exercício da cidadania planetária pode ser a solução contra os fatores que geram a poluição descontrolada, o desmatamento criminoso, o desenvolvimento de armas apocalípticas, a manipulação inescrupulosa dos genes, entre outros. Se por um lado vivemos numa efervescente época de avanços e descobertas científicas, o mundo apresenta tristes quadros de misérias, xenofobias, guerras e ataques à natureza (NISHITANI; SILVA, 2006, p. 1).

Usualmente a prática em sala de aula nesses trabalhos é semelhante: os alunos assistem a um filme ou leem um conto e, sob coordenação do professor, discutem questões éticas implícitas ou explícitas nas narrativas. Alguns pesquisadores acrescentam um questionário como instrumento de coleta de dados. Pelo que observamos, poucos apresentavam aos estudantes um texto analítico sobre a obra - prática que acreditamos ser essencial (como defendemos no capítulo VI).

De modo geral, considerando as pesquisas de diferentes países, confirmamos a divisão relatada por Piassi, e conseguimos entrever outra. Além de categorizar em pesquisas que se preocupam apenas com erros e acertos conceituais ou metodológicos e outras que abrangem questões sócio-culturais, também podemos classificar os trabalhos em domesticadores e emancipadores (estamos antecipando pensamentos de Paulo Freire que apresentaremos no próximo capítulo). Os primeiros acertadamente indicam o prazer propiciado pela cultura, mas frequentemente se esquecem de revelar a dialética aprisionamento-emancipação ideológica que ela carrega. Isso fica evidente inclusive porque vários autores sequer mencionam ou aprofundam o fato de a ficção científica ser um discurso muitas vezes influenciado pela indústria cultural. É justamente essa dimensão ideológica que será nosso foco em boa parte desta dissertação.

Dramatizando um pouco, existem propostas que vão maquiando, embelezando, fantasiando o Lobo Mau científico-ideológico de Vovozinha cativante para que o jovem aprendiz, encantado com a grandiosidade de seus olhos, boca e dentes, não perceba que está sendo devorado. O objetivo desses trabalhos é solapar eventuais resistências intelectuais ou emocionais para que o jovem desfrute da ciência. Concordamos em parte com esse objetivo. Ciência é cultura e, como tal, está aí para ser aproveitada por todos. E, com o ensino profissionalizante que domina muitas práticas pedagógicas, muita gente perde a vontade de se 
deliciar com esse conhecimento. Porém, não podemos esquecer que a ciência também pode ser usada como instrumento de opressão daqueles que se acham mais sobre aqueles que se acham menos. Nesse sentido, não podemos utilizar estratagemas ou subterfúgios que mascarem esse lado da ciência, pois é aí, nos seus limites, que se encontram aspectos importantes para escolhas críticas.

Em suma, no que se refere ao uso pedagógico da ficção científica, algumas perspectivas já começaram a ser desbravadas: a questão do imaginário, da criatividade, da afeição, do prazer em conhecer. E, dentre os trabalhos que pesquisamos, salvo a perspectiva de Cuartas, os outros autores não tocaram no ponto da emancipação (ao menos não explicitamente, pois algumas vezes entrevíamos essa possibilidade de leitura em meio a argumentações sobre uma aprendizagem crítica, uma preocupação com a organização social, etc.). Nesse sentido, nossa linha de raciocínio não parte da afeição nem da imaginação, mas da indignação. Não argumentaremos em favor do despertar da curiosidade a partir do prazer ou da criatividade (e nem ignoramos que isso seja possível), mas defenderemos que a origem da curiosidade pode também ser o incômodo com a injusta "ordem" social dominante. Isto é, mais do que pensar no como a ficção científica veicula os sonhos e os temores da humanidade frente à ciência e à tecnologia, acreditamos que educar é evidenciar como essas expectativas muitas vezes aprisionam nossos pensamentos e conduzem nossas atitudes, transformando-nos em difusores de uma ordem opressora.

Defenderemos que a educação começa no reconhecimento dos mitos implantados em nossas mentes, na percepção das ideologias, permitindo-nos rejeitar alguns engodos em que nos perdemos narcotizados 2 . Esse, para nós, é o início do ato educativo na atual "ordem" social. Resumindo: muitos autores partem do pressuposto de que o aprendiz encontrará sentido no estudo da ciência por meio do prazer. Tentaremos argumentar por outra via: o aprendiz pode encontrar sentido na aprendizagem pela percepção de que é oprimido e de que oprime, o que lhe possibilita mudar de postura frente ao mundo.

Porém não chegamos a essas conclusões de imediato. Acabamos adiantando a linha de chegada para o início do percurso. Permitam-nos corrigir a trajetória. Durante a dissertação tentaremos evidenciar os mitos incutidos em nossa mente que tivemos de deitar ao solo antes de construir tal visão de mundo.

\footnotetext{
${ }^{2}$ Talvez aqui façamos coro com uma declaração do escritor português, recentemente falecido, José Saramago (1922-2010), que disse a um jornalista quando saía de uma internação hospitalar em 2007: "Não sou pessimista, o mundo é que é péssimo. São os ditos pessimistas os únicos que querem mudar o mundo. Para os otimistas tudo está bem. Deveria se fazer profissão e militância do pessimismo" (Jornal da USP n ${ }^{\circ} 894,19-25 / 07 / 2010$, p. 16). Isso é o que poderíamos chamar de um "bom pessimismo", pois não entorpece e estanca, mas elucida e incita.
} 


\section{'A Máquina do Tempo'}

A principal escolha, que influenciou todas as outras e delimitou o perímetro de nossa dissertação, refere-se a nosso leitor ideal - aquele que supomos sobre nossos ombros enquanto redigíamos este texto. Não dissertamos pensando no pesquisador experiente. Cada capítulo, cada parágrafo, cada palavra foi escolhida para desmantelar os sorrateiros mitos subconscientes que cerceavam nosso raciocínio quando iniciamos esta pesquisa. Assim, nosso leitor ideal é um tanto inusitado. Imaginamos uma máquina do tempo com a pretensão de entregar este texto acabado a: nós mesmos, quando adentramos no mestrado. Para isso, descartamos muitos autores que nos auxiliaram a atingir nossa atual visão de mundo. Optamos nos alongar mais em alguns pensadores, concatenando-os de forma a criar uma linha de raciocínio suficiente para estimular nosso eu de anteontem a meditar sobre o ponto de vista deste trabalho.

Os pesquisadores experientes, habituados aos trabalhos de Paulo Freire, Ludwig Wittgenstein, Mikhail Bakhtin e Lev Vygotsky, podem se dirigir diretamente ao capítulo V sem prejuízo. Os primeiros quatro capítulos são destinados a levar nosso "eu ancestral" a refletir sobre as reformas fundamentais pelas quais a escola precisa passar. Impreterivelmente.

\section{REVELANDO A LiNHA DE RACIOCÍNIO DE NOSSA 'VIAGEM FANTÁSTICA'}

A questão que buscaremos responder com esta dissertação é: por que discutir a ficção científica na escola? A resposta a que chegamos está no título do trabalho. O que faremos será mostrar o processo que nos levou a tal conclusão. Não obstante nossa preocupação com o porquê, em alguns poucos momentos apontaremos como o fazer.

Adiantemos que, para responder tal questão com coerência, tivemos de confrontar alguns mitos dissimulados que descobrimos em nossa mente, para deles nos desvencilharmos. Freire evidenciará mitos político-pedagógicos. Com Zanetic desvendaremos mitos científicos. Mitos sobre a linguagem serão escancarados com Wittgenstein e Bakhtin. Estes últimos, em conjunto com Vygotsky, descortinarão mitos relacionados à psicologia. Com o respaldo da síntese dialógica desses autores, finalmente encararemos o universo e as possibilidades educacionais da ficção científica. Se a realidade escolar fosse outra, se esses mitos não reverberassem pela sociedade em mecanismos que minimizam homens e mulheres, os primeiros capítulos seriam desnecessários.

Destarte, a narrativa subsequente inicia-se em nossa leitura de Paulo Freire, com suas críticas à injustiça da rígida e massificante estrutura social refletida na/reflexo da amaciante 
instituição escolar. Começa com seu (nosso) desejo de uma mudança de postura frente ao homem, ao conhecimento e à escola. Com ele, aprenderemos que os homens mitigados apegam-se aos mitos. E é preciso ao homem assumir sua humanidade e sua história para que a educação se realize.

É neste sentido que, para mulheres e homens, estar no mundo necessariamente significa estar com o mundo e com os outros. Estar no mundo sem fazer história, sem por ela ser feito, sem fazer cultura, sem "tratar" sua própria presença no mundo, sem sonhar, sem cantar, sem musicar, sem pintar, sem cuidar da terra, das águas, sem usar as mãos, sem esculpir, sem filosofar, sem pontos de vista sobre o mundo, sem fazer ciência, ou teologia, sem assombro em face do mistério, sem aprender, sem ensinar, sem ideias de formação, sem politizar não é possível (FREIRE, 1996, pp. 57:8).

De Freire passaremos às reflexões mais específicas em relação à ciência. Para tanto, enveredaremos pelo compromisso ponderar-atuar característico da produção de João Zanetic. Enumeraremos suas críticas ao ensino propedêutico de física, cuja prática destroça o contexto para apresentar os conceitos em uma lógica supostamente didática, caracterizada por uma superespecialização que, na verdade, atua como um super-desestímulo. Tal crítica remete-nos a uma frase que ouvimos certa vez, atribuída a George Bernard Shaw:

O especialista é um homem que sabe cada vez mais sobre cada vez menos, e por fim acaba sabendo tudo sobre nada.

O aluno é soterrado com especificidades de visões de mundo que desconhece. Detalhes irreconciliáveis e enfadonhos que, para ele, não explicam o mundo. Sem aprender elementos para atuar no mundo e em si mesmo, é natural que ele desencante-se. Para ficar no universo da ficção científica, nas palavras de Robert Heinlein:

Um ser humano deve ser capaz de mudar uma fralda, planejar uma invasão, carnear um porco, pilotar um navio, projetar um edifício, escrever um soneto, puxar o saldo de contas, construir um muro, encanar um osso, confortar os moribundos, cumprir ordens, dar ordens, cooperar, agir sozinho, resolver equações, analisar um novo problema, carregar estrume, programar um computador, fazer uma refeição saborosa, lutar com eficiência e morrer corajosamente. A especialização é para os insetos (HEINLEIN apud ABRAMCZUK, 1981, pp. 36:7).

Esses aprendizados culturais, carregados de valores, são inescapáveis.

Segundo a práxis zaneticiana, como entendida por Ennio Candotti, a ciência impregna-se do clima da região, do espírito cultural de uma época. Ela imiscui-se nos/dos sonhos, anseios, desejos, projetos de uma arena histórica. Repleta de seres humanos, de seus fazeres e quefazeres, sua objetividade é também subjetiva, pois representa visões econômicas, 
filosóficas, políticas... Sua produção é contextual, coletiva e intersubjetiva. Seu romance explicita os valores dos sujeitos que a escrevem. "E os valores pertencem à esfera da cultura" (CANDOTTI, 2009, p. 17). O que gera novas possibilidades de atuação pedagógica.

Posteriormente, com Wittgenstein e Bakhtin, passaremos rapidamente pelos bosques da filosofia da linguagem, intentando tão somente desvendar novas visões (pelo menos para nós) sobre a relação entre realidade, pensamento e linguagem. Nesse momento, finalmente buscaremos compreender como a ideologia imiscui-se na linguagem, aprisionando-libertando nossa forma de pensar e atuar no mundo.

Em Vygotsky vamos buscar um mínimo de embasamento psicológico para tal relação, que não busca esgotar o assunto, mas apenas balizar nosso raciocínio indicando se ele está consistente ou não. Com ele, o objetivo principal será derrubar alguns mitos que danificavam nossa concepção da psicologia da aprendizagem. Dentre eles, alguns referentes à relação entre o conhecimento cotidiano e o científico.

Feito isso, separamos um capítulo para sintetizar tais referenciais. Pretendemos, nesse ínterim, que a filosofia da linguagem bakhtiniana sirva de cola, de "glúon" entre a ideologia pedagógica freiriana e a psicologia vygotskyana. E mais, que seja "Bóson de Higgs" que materialize, concretize e dê sustância a essa relação.

Antecipando, podemos dizer que, observando as produções culturais da física, diríamos que a linguagem científica, sua sonoridade, sua leitura como música do cosmos, encanta ou assombra em sua magia. E é justamente o desvelar crítico da harmoniosa cortina mágica que pode concretizar a aprendizagem. Decompor a composição melódica é instrutivo. Desmistificar é aprender.

No capítulo $\mathrm{V}$ chegamos finalmente à ficção científica, defendendo-a como contexto válido e inquietante para a aprendizagem da linguagem científica; como contraponto a uma educação bancária que descontextualiza brutalmente os conceitos, reduzindo a linguagem e sabotando o pensamento. Contexto válido que, em seu caráter narrativo, em seus valores e suas ideologias, abre espaço para o posicionamento intelectual dos (ontologicamente inquietos) educadores e educandos, fomentando o engajamento e abrindo as portas da curiosidade epistemológica. Depositamos nossa confiança de que decodificar esse elemento da cultura, simbiose entre ciência e arte, é uma forma de aprender a linguagem científica. Problematizar essa linguagem é uma forma de olhar criticamente para as ideologias que ela carrega.

Por conta disso, abanamos um leque de autores que analisam a ficção científica para, na ventania gerada, tentar vislumbrar as peculiaridades desse (sub)gênero do discurso. Apontamos, nesse ínterim, uma estratégia de ensino que pode servir de guia para a 
reestruturação da retórica científica, um guia para o raciocínio do educando, bússola certamente passível de futuras incrementações.

No último capítulo, a cargo de exemplo, apresentamos alguns estudos de caso. Porém, como os eventos analisados são anteriores à sistematização teórica apresentada, é uma investigação meramente qualitativa.

Pois bem, iniciemos a viagem...

'Que a Força esteja com você!' 


\title{
Capítulo I
}

\section{ESCOLA: O VELHO E O NOVO}

$O U$

\author{
'FUNDAÇÃO'
}

- A violência - foi a resposta - é o último refúgio da incompetência.

Isaac Asimov, 1982, p. 52.

Este capítulo resume nossa leitura da denúncia de Paulo Freire à violência da estrutura educacional usualmente em voga em muitas escolas. Delação que adotaremos como fundamentação, alicerce, fundação de nosso castelo teórico. 
Nossa escola ideal (o que não quer dizer utópica) seria caracterizada pelo acesso à cultura, possibilitando ao aluno subvertê-la ou usufruí-la. Esse ideal, de certo modo, resume a essência do problema educacional na leitura de mundo que adotamos. A escola é o ponto de encontro entre o conhecimento do passado e aqueles que construirão o conhecimento futuro. É o ponto de encontro entre o sistema e o indivíduo, entre o macro e o micro. É o contexto espaço-temporal de interação entre diversas visões de mundo.

Caricaturalmente, podemos dizer que na escola existe o choque entre o impulso subversivo dos jovens e o hábito conservador dos adultos. Dizemos caricatural porque o problema não é tão simples assim. Nem sempre o jovem tem ímpetos subversivos, nem sempre o adulto possui posturas acomodadas. Mas, de um modo geral, podemos analisar a situação escolar através da dualidade VELHO $\leftrightarrow$ NovO. De um lado o passado, do outro o futuro. De um lado tradição, do outro, subversão. Isso vai longe: imitação $\leftrightarrow$ criação, interesse público $\leftrightarrow$ liberdade individual, certeza $\leftrightarrow$ incerteza, dependência $\leftrightarrow$ autonomia...

Podemos utilizar o filme Matrix como metáfora dessa situação ${ }^{3}$. Nele, o personagem principal Neo, o novo, luta contra a Matrix, a matriz, o sistema - representado pelos agentes de semblantes propositalmente similares: Smith, Jones, Brown (poderíamos traduzir esses como Silva, Oliveira... sobrenomes comuns). É o novo lutando contra o velho, é o indivíduo tentando não se tornar mais um, idêntico, deformado e massificado na estrutura do sistema. Sistema artificial, diga-se de passagem. Voltaremos a essas interpretações posteriormente.

A questão é saber se aquelas relações são puras dicotomias ou se são um espectro contínuo ligando pólos opostos, mas não excludentes. As ideias de Paulo Freire são muito ricas para sistematizar tal debate.

\section{I.1 - Paulo Freire - Denunciando um 'Estado de Medo'}

Certamente a visão pedagógica de Paulo Freire (1921-1997) possui uma contextualização sócio-histórico-cultural. Tal contexto é dado por sua vivência como educador a partir da década de 40, e é eximiamente narrado pelo próprio Freire no seu ensaio Educação como prática da liberdade, cujo prefácio de Francisco Weffort também é bastante

\footnotetext{
${ }^{3}$ Sinopse: após os humanos desenvolverem a Inteligência Artificial, as máquinas se voltam contra eles, passando a usar o corpo humano como fonte de energia. Para tanto, elas mantêm os corpos ligados a uma realidade virtual denominada Matrix. Entretanto, alguns humanos tomam consciência desse fato e se libertam, formando um foco de resistência. Nesse contexto, Morpheus, um dos líderes da resistência, está à procura do escolhido: um homem que, segundo uma lenda, seria capaz de livrar os humanos do domínio da máquina. Ele acredita que este escolhido é Neo. A trilogia tem como foco o despertar e a evolução do escolhido, até a batalha final - quando ele tenta libertar os humanos dessa escravidão inconsciente.
} 
revelador. Porém, acreditamos que sua pedagogia não perdeu a atualidade por, no mínimo, dois motivos. Primeiro: porque seu contexto não perdeu a validade - nossa realidade nacional continua baseada na relação opressor $\leftrightarrow$ oprimido. Segundo: porque sua práxis pedagógica libertadora baseia-se justamente na problematização da realidade histórica dos educadores e educandos.

No Esclarecimento que antecede ao ensaio Educação como prática da Liberdade, a frase inicial cunhada por Freire revela a linha axial de suas ideias:

Não há educação fora das sociedades humanas e não há homem no vazio (FREIRE, 1978, p. 35).

Fica mais do que evidente a importância que ele dará à cultura e ao diálogo em toda a sua linha de raciocínio. Algumas palavras e frases são muito recorrentes na exposição que Freire faz de sua leitura da educação e da sociedade. Tentaremos utilizá-las captando o essencial de suas reflexões.

Ele caracteriza o ensino de seu tempo como uma massificação, e não como uma educação. Essa massificação acaba por garantir a manutenção de uma sociedade gregária, opressora e fechada. É um ensino alienante, que domestica, instrumento de dominação de opressores sobre oprimidos, que permite preservar um sistema rígido, estático, caracterizado pela imobilidade. É um ensino antidialogal, anticomunicativo, que impõe o mutismo. Vertical, caracterizado pelas receitas, pelas prescrições, pelos decretos. Em essência, pela imitação. Existe o professor-que-sabe, que ensina, e o aluno-que-não-sabe, que aprende. $\mathrm{O}$ professor anuncia, não dialoga.

Freire denomina tal ensino em que o estudante é considerado uma tábula rasa vasilha vazia a ser preenchida pelo professor - de educação bancária. É um dirigismo fundamentado em depósitos, regido por uma relação de antipatia, de desencontro entre os indivíduos. Entre outras coisas, essa educação é caracterizada por um verbalismo oco, por uma verborragia, por "um diletante jogo de palavras vazias - quebra-cabeça intelectual - que, por não ser reflexão verdadeira, não conduz à ação" $(2005$, p. 60$)$.

Tudo isso avaliza uma sociedade sem povo, onde o homem, minimizado, debilitado, deformado, alienado, objeto, apenas assiste à história passar. Ele não está com $o$ mundo, ele está no mundo. Passivo, ele se adapta, se acomoda, se ajusta e aceita a realidade que lhe é prescrita. Nessa sociedade sectária que lhe é sobreposta, onde se encontra imerso e inconsciente da própria situação, ele vive esmagado, com medo da solidão e da liberdade. Ilhado, silenciado, coisificado, desumanizado, acostuma-se a ser oprimido. Conforma-se na violência. Acredita que a realidade opressora é intransponível e invulnerável. Incorpora um 
fatalismo que lhe estagna e lhe impõe finalidades. Não percebe que tal fatalismo é uma situação histórica e sociológica, e não ontológica. Não existe, vive. Mal vive, sobrevive.

Sua postura é acrítica. É um espectador da própria existência. Proibido de ser, admite ser menos e saber menos. Abatido, sente-se incapaz, descrente em si mesmo. Autodesvalidase. Apenas estabelece contatos, e não relações. Não tem voz. Não cria, nem recria o mundo. Não transforma. É um escravo, um autômato. Tem medo dos mitos e dos titãs que aceitou como imagem do mundo. Quando com fome, não tem fome de cultura. Quando sem fome, não quer desestabilizar o que parece lhe convir. Repete-se, apático, em atos-reflexos descriticizados. Admirável gado novo.

Fenecendo em sua insegurança vital, morto em vida, petrificado, perpetrando sempre mais do mesmo, não ousa. Mas, como diria Pessoa (1999, p. 51):

Sem a loucura que é o homem

Mais que a besta sadia,

Cadáver adiado que procria?

Os mitos acatados são pactos silenciosos, camuflados (e muitas vezes inconscientes) entre opressores e oprimidos. Embustes, lendas pulverizadas, invisíveis, que "vão inoculando nos indivíduos o apetite burguês do êxito pessoal" (FREIRE, 2005, p. 170), em que ser mais é sinônimo de ter mais e não de saber mais. Fantasmas sombrios que induzem uma dicotomia entre "superiores" e "inferiores". Um folclore diluído e complexo que atua sorrateiramente em prol da "ordem" dominante, afastando a esfera das decisões para uma órbita distante dos indivíduos. Estes, impotentes, tapeados, sentindo-se solitários, tornam-se prisioneiros de visões de mundo que não são suas. A sensação que fica é drummondiana: E agora, José?

Uma boa imagem para essa sociedade, para essa máquina de moer povo, para a engrenagem dessa estrutura dominadora é a do filme Metropolis de Fritz Lang, em que operários catatônicos repetem, turno após turno, movimentos mecânicos para produzir objetos comercializáveis que desconhecem. E uma boa imagem para a escola desse sistema desumanizante é a do filme The Wall do grupo de rock inglês Pink Floyd, em que estudantes idênticos (leia-se "já domesticados”), extraídos de sua individualidade, subordinados, passam por uma máquina de fazer tijolos.

Além do oprimido, existe em antagonismo o draconiano opressor ${ }^{4}$. Este, afogado nas tentativas de sustentar a sociedade dual que lhe convém, também não é livre. Apega-se a uma

\footnotetext{
${ }^{4}$ Essa leitura "bipolar" (opressores de um lado e oprimidos de outro) e até certo ponto ingênua que fizemos do trabalho de Paulo Freire em um primeiro momento acabou aprofundada após lermos Bakhtin e Vygotsky e percebermos que a opressão reside em cada um de nós, que o "lado negro da força" imiscui-se em nossa forma
} 
educação verbosa, superposta à realidade. É um descrente. Não acredita no homem. Não ama. Não respeita. Rouba-lhe a palavra. É um arrogante fanático e ingênuo. Explora, engana, ludibria, confunde, trapaceia. Adora seu poder exacerbado e a submissão. Regozija-se com sua rígida autoridade, com sua reputação. Acredita ser parte de uma cúpula de homens eleitos, detentores do saber. Cria e é criado por um sistema que o subjuga.

É, portanto, possessivo, ganancioso. Apodera-se da verdade e dos homens - ser mais, para ele, é ter mais. É sua própria violência que o desumaniza. Prende-o ao que ele é, e não ao que ele pode ser. Reverencia o produto e, portanto, a morte. Não ama o processo e a vida. Imagina que a história sempre foi e será assim. Acredita piamente que o massificado na verdade é incapaz, ignorante e, quiçá, preguiçoso. Por isso se vê como o salvador. Em sua ânsia necrófila, utiliza o discurso da manutenção da liberdade do povo para, consciente ou inconscientemente, oprimi-lo. E segue sabotando, vigiando e punindo quando necessário (necessário para a manutenção de uma falsa liberdade em que ele mesmo vive). Controla e coisifica, impedindo a manifestação da alma do oprimido, que se torna inanimado.

A ação estabilizadora dessa elite dominadora (que, mesmo divergente, harmoniza-se rapidamente quando algo ameaça esgotar seu poder) se realiza em vários âmbitos. A teoria de sua ação logra-se nos seguintes preceitos: ela divide, para manter a opressão; manipula, propagando seus mitos, sua ideologia; e invade econômica e culturalmente o povo, roubandolhe a fala, a expressão e conquistando-lhe a cultura ${ }^{5}$.

A massa torna-se espectadora de uma realidade ilusória que lhe é sobreposta. Consome, descriticizadamente, os valores, os padrões de vida, o comportamento, a vestimenta, a linguagem, as finalidades da elite. O modo de vida desta, sua ótica do mundo, torna-se pauta do dia dos indivíduos que, imaturos politicamente, gregarizados, passivos, carentes, inautênticos, mimetizados, alienizam-se.

A invasão (colonização) cultural, portanto, freia a criatividade, a originalidade. É uma "cultura do silêncio". Os invasores é que são sujeitos, autores e atores do processo; os invadidos são meros objetos. Aqueles modelam, estes são modelados. Os primeiros optam, os outros seguem sua opção. "Os invasores atuam; os invadidos têm a ilusão de que atuam, na atuação dos invasores” (FREIRE, 2005, p. 173).

de pensar quando incorporamos a linguagem de determinada cultura. Ainda assim, para que ficasse clara a evolução de nossa forma de considerar esse assunto, mantivemos a leitura simplista e dicotômica neste capítulo.

${ }^{5}$ Brian K. Cameron, em "Qual é seu desejo, meu mestre?": Guerra nas Estrelas e a luta de Hegel por reconhecimento (In: IRWIN, 2005), ajudou-nos a entender tal mecanismo de controle analisando o enredo de Star Wars. O texto de Peter Fosl em Lost e a filosofia (IRWIN, 2008) também nos acudiu. 
Pior. Essa invasão nem sempre é deliberada. "Muitas vezes os seus agentes são igualmente homens dominados, 'sobredeterminados' pela própria cultura da opressão" (FREIRE, 2005, p. 175). Influenciados pelo "clima" da época, reproduzem e propagam a estrutura, o estilo, a estética dominante e suas instituições condicionantes. Instituições essas (escolas, lares, etc.) que funcionam como agências formadoras de futuros invasores, disseminadores do contexto sócio-histórico opressor. O invasor, sua essência forjada, seu ser cultivado é dual: concomitantemente efeito e causa da dominação. Apenas mais um tijolo no muro das repressões.

Em resumo, para Freire, a invasão pode dar-se entre os valores e ideologias de uma "sociedade matriz, metropolitana" sobre uma sociedade dependente; ou ainda, implicitamente, dentro de uma mesma sociedade, entre suas classes (2005, p. 174).

Há ainda algumas boas almas que se descobrem opressoras e engendram ações benevolentes ${ }^{6}$. Contudo, muitas vezes, seus esforços caracterizam-se por atos sobre ou para o povo; e não com ele. Continua vertical. É um assistencialismo, uma concessão. Mantém, de certa forma, as prescrições, as imposições e os mitos. É um amaciamento, uma extensão, e não uma comunicação. É uma benignidade deformada, de cima para baixo, e não de dentro para fora. Relutante em relação à capacidade do homem, equivoca-se. A gente sofrida continua vendo a banda passar cantando coisas de amor.

Metástase da ordem opressora, essa boa alma se coloca na posição daquele que oferece, e não daquele que se abre para uma permuta. Supõe que a democratização da cultura é sua vulgarização. Sua boa fé acaba alimentando a passividade. Sua generosidade, no final das contas, é falsa, permite a permanência da injustiça e é instrumento de desumanização, de dominação. É mediadora das necessidades das oligarquias. Falso amor, falsa caridade, falsa liberdade. A práxis libertadora é muito mais radical do que esse paternalismo hipócrita, que esse populismo dependente da existência da massa dócil. Não é humanitarista, é humanista!

Freire defende que o homem deve ser sujeito de sua história. Que a educação deve ser uma força de mudança e de libertação, respeitadora do homem como pessoa. Que ela deve humanizar, não oprimir. Que a sociedade não deve ser fechada, mas aberta. Dinâmica, plástica. Essa mutabilidade seria garantida pelas discussões e pelos debates. Pelo diálogo. Caracteriza-se, portanto, por uma comunicação com o povo, e não pela realização de comunicados para o povo (que, assim, seria massa, e não povo).

\footnotetext{
${ }^{6}$ Um exemplo clássico de uma ação desse tipo é a escola "Owenista", na Inglaterra do século XIX, voltada para a educação dos trabalhadores. Essa escola nasceu a partir do empenho do empresário galês Robert Owen (17711858), que socializou suas empresas com os trabalhadores (JOHNSON, 1976, p. 50).
} 
Dessa forma, o homem se torna sujeito, responsável pelas próprias escolhas, crítico, participativo. Ele é ativo na própria biografia e não uma marionete biológica ou social. Engajado, assume uma postura de autorreflexão e de reflexão com seu tempo e espaço. Realiza-se autor de sua própria cultura. É um ser de relações e não de meros contatos. Está com o mundo, e não apenas no mundo. É capaz de discernir, de desejar e transcender o próprio tempo, visualizando-se emerso da própria situação em que vive. Existe, e não apenas vive. Não é um ser de acomodação, mas de ação. Não é um ser de adaptação, mas de integração. Não apenas imita e se ajusta, mas cria em comunhão. Inventa e reivindica. Decide. Escolhe. Humaniza a realidade e faz cultura. Assume a sua vocação ontológica e histórica: a de Ser Mais.

Como afirma um sujeito por excelência, Mário de Andrade (1997, p. 123):

Não vim no mundo para ser pedra.

Humilde, o homem-sujeito tenta transformar pelo diálogo. Nunca esmagar pela imposição. Não rouba a palavra. Não participa do assalto desumanizante. É silencioso, não silenciado. Não sente um anseio de se fazer ouvir somado a uma indiferença por ouvir a opinião dos outros. É silencioso para estar atento e ouvir. Opta por falar quando acredita necessário. Possui uma fala autêntica, representativa de seu mundo, e não de propagandas alheias a sua realidade. Reverencia a cooperação, e não a competição. A colaboração, não o individualismo. E isso não deve ser encarado como uma negação do $e u$, mas uma afirmação do nós. Não é deixar de pensar em si para pensar somente no outro. Não é a mera negação do sucesso pessoal, do êxito, do sujeito, mas a integração desse como cocriador da sociedade, em uma realidade a se construir.

Essa é a convivência autêntica. Horizontal. Baseada na simpatia. Ela não confunde respeito com submissão. Não confunde adesão com aderência. Não alimenta a hierarquia desumanizante. O todo, e não somente a parte, é importante. É a derrocada da metonímia, metaforicamente falando.

Finalmente comprometido, eminentemente lúcido, o homem-sujeito renuncia à expectação e exige a ingerência. Não mais passivo, torna-se impaciente, impetuoso. Demonstra o arrojo característico do estado de busca. Admira. Aventura-se. Reflete e age. Fazer e quefazer solidários. Sua práxis é a transformação da realidade objetiva e desafiadora desvelada pela racionalização subjetiva, por sua intencionalidade. $\mathrm{O}$ espaço não é dado $a$ priori. Temporaliza-se o espaço. Entender o mundo é desmitificá-lo. O homem, nesse 
processo, humaniza-se, historiciza-se. Insere-se criticamente na dialeticidade objetividadesubjetividade. Afinal, não há história sem homens.

Nessa visão de mundo, o desenvolvimento da sociedade inicia-se na ação cultural dialógica e prossegue na contínua revolução cultural, fundamentada nas potencialidades do ser social em que se gera. Emerso e perenemente emergindo-se, o homem retoma sua palavra, sua expressão, sua cultura. Na nova condição concreta do processo histórico, mulheres e homens, unidos em sua intersubjetividade, emancipados, destituem a elite dominadora da continuidade de seu poder, de sua hegemonia.

A ação cultural opera como antídoto. A teoria de sua ação é oposta à teoria dominante. Não separa para oprimir; une para libertar. Não manipula para propagar sua ideologia; organiza o diálogo para desmitificar e compreender o mundo e a situação dos homens. Jamais invade culturalmente para roubar a palavra e amortecer o ânimo criador dos invadidos, negando sua cultura, mas estabelece a síntese cultural para, em um diálogo respeitoso com a outra cultura, enriquecerem-se todos, possibilitando a eterna libertação, a perene busca de uma estrutura social revolucionária, constantemente justa.

$\mathrm{Na}$ escola, não mais existe o opressor e o oprimido, o que sabe e o que não sabe. Ela torna-se um círculo de cultura baseado no diálogo corajoso onde tanto o educador quanto o educando aprendem e ensinam, recebem e oferecem, onde ambos buscam Ser Mais e Saber Mais. O professor torna-se um coordenador de debate, um educador-educando, e o aluno, um participante de um grupo, um educando-educador. Eles fomentam, em si mesmos e nos outros, a criticidade. Opressor e oprimido, assim, se libertam, se recuperam de uma estrutura social que os desumanizava. Restauram a intersubjetividade. Tornam-se crentes. Respeitam e amam.

Suas reconstruções iniciam-se no autorreconhecimento de homens destruídos pela estrutura da “ordem” opressora. Esse é um ponto nevrálgico!

O oprimido, em sua tomada de consciência, não pode se tornar opressor do opressor. No processo, ele liberta a si e aos opressores. Deve desvencilhar-se da dependência emocional, da crença na qual viveu até então: a de que ser homem é ser opressor. Não deve aspirar imitar-lhe o padrão de vida. Deve perceber a contradição da realidade opressora onde estava imerso. Não deseja contraditoriamente uma falsa libertação que busca a identificação com a atitude do antigo pólo opressor. A libertação da contradição opressor $\leftrightarrow$ oprimido é a libertação de todos, não a promoção de oprimidos a opressores. Assim, restaura-se a humanidade de ambos. 
Em suma, "ninguém liberta ninguém, ninguém se liberta sozinho: os homens se libertam em comunhão" (FREIRE, 2005, p. 58). Ambos assumem o papel do homem: o de criador de cultura. Assumem-se seres inconclusos e conquistam suas liberdades. São autorresponsáveis pela busca de Saber e Ser Mais. Escolhem a nova e permanente condição: a do homem libertando-se. Encontram uma razão de ser. Uma razão de ser mais, e não apenas de estar sendo.

A Pedagogia do Oprimido, portanto, é forjada com ele e não para ele. Educando e educador não são mais avaliados somente pelo que repetem, mas também pelo que eles criam. Pelo elemento de cultura que desenvolvem - em diálogo com o precedente e desejosos de construir o porvir. Dessa maneira, fazem história e transformam objetivamente a situação opressora. Culturalmente se libertam da cultura da dominação. Emergem do que estavam sendo para se preocuparem com o vir a ser. Superam o profundo medo à liberdade. Desvencilham-se da mera nostalgia e promovem uma ação cultural pela liberdade. Criam e constroem. Em uma reflexão dialética e aberta, sem conclusão pré-estabelecida.

Isso não quer dizer que a nova postura e a nova situação serão alcançadas com facilidade. É difícil não se acomodar. É difícil sair da "zona de conforto".

Ser livre exige esforço porque ser culto exige esforço.

\section{I.2 - 'VinTe Mil LÉguAs SubMarinas'}

Voltando àquelas nossas dualidades iniciais, vemos que o velho e o novo não podem constituir uma dicotomia. Assim representariam justamente aquela educação bancária, em que temos o certo e o errado, o que ensina e o que aprende, o que detém o conhecimento e o que não o detém, etc. Temos a situação em que o aluno é rotulado. Ele adere ao papel que lhe é pregado, destinado, e aceita "seu" destino. Etiqueta-se e etiqueta aos outros, opressores e oprimidos. Por fim, classificado, transforma rótulo em invólucro e engessa-se. Enclausurado, acredita somente no que é (ou acha que é) e deixa de pensar no que pode ser. Fruto de um contato antidialógico e antipático, não reverencia o velho e nem cria o novo. Não é uma educação, é um embuste, um engodo.

Nesse sistema, no qual o jovem permanece imerso nas profundidades de reflexões que não são suas, o aluno aprovado é um sobrevivente, um náufrago, que muitas vezes aprendeu a nadar mecanicamente, por força. O aluno reprovado, na verdade, afogou-se. Asfixiou-se em erros, não somente seus. É um inadequado, mas talvez tenha passado a acreditar ser inerentemente incompetente, impotente. 
Na escola ideal, sustentada na relação dialógica, o educando possui a semente da reverência pelo conhecimento em seu interior, e o educador ainda possui em si o germe vivo da curiosidade. Uma boa imagem para representar essa maneira de encarar a função social da escola para cada indivíduo e o relacionamento do par educador-educando é o símbolo yinyang. O novo reverencia o velho e o velho possui em si o germe do novo. O passado guarda a origem do futuro e o futuro mantém em si referências ao passado. Assim, o velho não envelhece e o novo não permanece ingênuo. $\mathrm{O}$ hífen acima utilizado é muito simbólico.

Nesse contraste, nessa relação entre o ontem e o amanhã, o que importa é o hoje. É no hoje que essas relações se sustentam, é nele que elas podem atingir seu ideal.

É preciso fazer o possível hoje, para que possamos fazer amanhã o que é impossível fazer hoje (FREIRE apud ZANETIC, 2009, p. 295).

É agora, José! É no presente que o "choque" de gerações, que o encontro entre o velho e o novo, entre o conhecimento passado e o conhecimento futuro pode se tornar um debate rico em que tanto o educador quanto o educando têm muito a ganhar. Aqui, nenhuma voz é silenciada. O silêncio aparece sob a forma de respeito, sob o desejo de alimentar o debate. Cada um se torna silencioso, e não silenciado, aprendendo a ouvir e a ser ouvido. $\mathrm{O}$ diálogo se torna crítico e libertador. Nesse contexto, não importa o que se é, mas o que se quer ser. É essa atitude, é a consciência dessa possibilidade humana que permite uma relação dialógica baseada no respeito, mas voltada para a autonomia.

Enquanto a educação for subentendida como um confronto de gerações, e não um convívio, pouco ela irá mudar. No encontro entre diferentes visões de mundo, entre diferentes culturas, o conflito não é a única opção. Aquelas polarizações apresentadas inicialmente, portanto, não podem ser encaradas como dicotomias verticais, mas como complementaridades, dualidades horizontais. Espera-se, com isso, que o par educador-educando e educandos-educadores possua uma postura dual, ora demonstrando uma reverência ao conhecimento do passado, ora criando o futuro. Preservando e renovando. Essa postura exige também confiança. Confiança no processo do outro. Da confiança nasce a autonomia.

Ninguém é sujeito da autonomia de ninguém (FREIRE, 1996, p. 107).

\section{I.3 - 'MATRIX RELOADED'}

Façamos uma releitura de Matrix para ilustrar essa discussão. Ela nos será útil para expressar o caminho do Novo e do indivíduo frente ao sistema. O primeiro filme narra o 
despertar do Novo. Ele descobre-se monitorado, sonambúlico, força-motriz e bateria do próprio sistema que o incomoda. Ao se reconhecer oprimido, engaja-se em um estado de procura e caminha para fora da caverna platônica. Percebendo a própria ignorância, engendra uma odisseia socrática em busca da gnose $^{7}$.

O autoconhecimento é a chave sem a qual não podemos destrancar nenhum outro conhecimento que valha a pena ter (IRWIN, 2003, p. 46).

Morpheus, personagem que incita e guia os oprimidos a libertarem-se por meio do diálogo e dos questionamentos, chega a afirmar que cada oprimido profundamente inconsciente de sua condição é parte do sistema, sustenta-o. Ele não fala, é dublado (ZIZEK, 2003, p. 263). Despreparado para ser desconectado da matriz, inerte, dependente do sistema, acaba lutando para protegê-lo.

...pior que uma prisão para a sua mente é uma prisão que você nem sabe existir; portanto, uma prisão de onde você nem tenta escapar (IRWIN, 2003, p. 47).

A percepção da escravidão involuntária à realidade opressora pode ser dolorosa, difícil. Tendo sido domesticado, forjado dentro dos velhos mitos, negá-los é, em parte, negar a si mesmo. Muitos sequer acreditam que tal negação seja válida frente ao conforto morno que a estrutura dominante incute como valor máximo a ser seguido. É o caso de Cypher que, cansado do perene estado de busca, evasivo, pretende retornar ao conforto, à acomodação alienante. Compreensível, uma vez que estar livre de não significa estar livre para (SCHICK, 2003, p. 118). O propósito é o alimento da alma.

No sistema, o indivíduo não nasce, é cultivado. E o velho é introjetado nas veias do novo. Ainda que no filme essa transfusão seja material, simbolicamente podemos encará-la como a incorporação de valores alheios e antigos pelos indivíduos que estão sendo cultivados.

Nesse contexto, Smith - um representante do sistema, um opressor programado pela matriz - literalmente rouba a fala do oprimido ao subtrair-lhe a boca. A sala de interrogatório onde tal cena se passa é monitorada, e a vigilância se mostra por meio das TVs de um sistema de segurança. A burocracia, instrumento de manipulação e persuasão, evidencia-se em um calhamaço, um provável processo judicial do sistema contra o Novo. No fim, a violência se torna física e a inquisição se torna invasão.

\footnotetext{
${ }^{7}$ Confissão: em meados de 1999, vivíamos, e não existíamos, amaciados pelo sistema. Naquele ano, M. Gomes Jr., professor de literatura, içou-nos do infomar em que nos afogávamos ao nos emprestar livros de Fernando Pessoa e, meses depois, discutir conosco o filme Matrix. Em suma, foi o diálogo sobre esses elementos da cultura que nos incitou à leitura: do mundo e de livros. Entre outras coisas, é por gratidão e reconhecimento que utilizaremos Matrix e várias poesias em muitos pontos de nossa dissertação. Ademais, supomos que tais incursões deixam o texto menos árido e mais saboroso.
} 
No desenrolar da história, acompanhamos o "treinamento" do novo em sua preparação para enfrentar o sistema. Ele aprende o funcionamento, a estrutura da matriz. Dentre as leis que simbolizam a verticalidade dessa estrutura, uma delas fica evidente durante todo o filme: a gravidade. Na linguagem do cinema, ela é representada na forma de chuva, água escorrendo na janela, celular precipitando-se prédio abaixo, água fluindo em uma fonte, cartuchos desabando do céu, corpos caindo vertiginosamente de cima dos telhados ${ }^{8}$ e letras descendo pela tela dos computadores. Simbolicamente, subverter o sistema é deformar essa regra, o que os rebeldes tentam fazer com certa frequência ao andar pelas paredes e pular entre prédios distantes.

O ápice dessa história ocorre quando o Novo, como a bela adormecida, ressuscita por meio do amor. Ele reconstrói-se e acaba por compreender e desvelar a estrutura e a linguagem (verde) do mundo dos opressores. Nesse momento epifânico, repentinamente lúcido, ele consegue manipular e transformar esse mundo - muda a própria práxis e impede que os opressores o agridam ${ }^{9}$.

É interessante notar que, em um filme onde o despertar possui tremenda importância metafórica, o personagem principal aparece acordando inúmeras vezes durante toda a trilogia. No primeiro filme, várias de suas cenas se iniciam com ele acordando. Na verdade, a primeira cena dele nos três filmes é o despertar. No primeiro, ele acorda no mundo virtual. No segundo, no mundo real. E no terceiro, no meio termo, no limbo.

O filme termina com uma fala do $N_{o v o}{ }^{10}$. Diálogo escancarado com o espectador. Sem receios de inteligência. Ele afirma que está inconcluso. Que assumiu sua postura de homem perenemente libertando-se. Que o futuro é uma incógnita, que não sabe como a luta vai terminar, mas sabe como ela vai começar. Que sabe que o espectador, se oprimido, está com medo. Com medo dos oprimidos despertos. Com medo das mudanças. Mas ele, o Novo, vai buscar um mundo sem regras e sem controle, sem limites, nem fronteiras. Um mundo onde tudo é possível. E finaliza: "para onde vamos a partir de agora, é uma escolha que cabe a você" (MATRIX, 1999, 02h08m35s).

\footnotetext{
${ }^{8}$ Aliás, a primeira cena de Matrix lembra a abertura do filme Um corpo que cai (Vertigo) de A. Hitchcock.

${ }^{9}$ Existe uma interpretação Marxista do filme. Em Matrix, Marx e a Vida de uma Bateria (In: IRWIN, 2003), Martin Danahay e David Rieder apresentam ideias complementares àquilo que afirmamos até esse ponto. Contudo, como tal texto foi produzido antes dos últimos dois filmes da trilogia, acabaremos mostrando elementos que eles estavam impossibilitados de discutir.

${ }^{10}$ A propósito, esta é a primeira fala do protagonista com mais de duas ou três frases. Até então, todas as suas enunciações eram curtas, e em sua maioria perguntas - o que ajuda a construir e mostrar a personagem como alguém no estado de busca, de procura.
} 
Como desfecho, ele sai da cabine telefônica e vence a regra máxima, simbólica, vertical, da gravidade: ele voa! Super-homem. Enquanto isso, sobe a trilha sonora: a música Wake-up da banda Rage against the machine. Escolha precisa.

Se o primeiro filme fala sobre o nascimento, o segundo fala sobre a vida. É o Matrix Reloaded. O Novo faz uma releitura do mundo onde vivia. Questiona o que é controle. Pergunta-se se realmente tem o domínio das próprias escolhas. Descobre novas formas de controle e não sabe em quem confiar. Alça-se para fora do tempo e adquire certa clarividência. Depara-se com as boas angústias de estar existindo. Realiza perguntas pertinentes e irrelevantes. Reflete e age. Efetua escolhas e, acima de tudo, busca compreendêlas. Continua transformando o mundo. Humaniza-se e historiciza-se.

Percebendo a contradição da situação dominadora, questiona à personagem Oráculo: “o que todos os homens com poder desejam?". No que ela responde: "Mais poder". Certamente essa é a palavra de ordem da elite opressora.

Nesse segundo longa-metragem, um antigo opressor retorna. O ex-agente Smith. Em sua luta com o Novo, ele de alguma forma desconectou-se do sistema. Desligado da matriz, porém ainda vivendo nela, sente-se compelido a desobedecer e perde o propósito. Pária do mundo que o criou, confunde-se, complica-se, não sabe o que fazer. Diz-se "aparentemente livre" e afirma saber ser isso uma mentira. Por fim, na busca de um novo propósito que o defina, continua opressor e tenta impor ao Novo sua própria identidade. Acaba por sair do controle do sistema e impõe sua individualidade a todos que encontra. Torna-se opressor do opressor. Não respeita, não ama, agride.

De forma breve, podemos dizer que nessa releitura do sistema, o Novo intenta libertar mais pessoas, e o velho tenta cada vez mais roubar-lhes a identidade. Este filme acaba com o Novo descobrindo que é parte do sistema. Que é apenas mais um que, ao assumir o papel de salvador, de messias, é instrumento de manipulação e opressão. No fim, ele descobre-se como uma anomalia sistêmica na harmonia da matriz. Uma anomalia natural, indelével, controlável e aparelho ideológico de controle.

Ele conhece o Arquiteto da matriz, o criador do sistema, que afirma que o ser humano é ontologicamente incapaz de viver em um sistema perfeito, justo. Que o homem é inerentemente imperfeito, monstruoso. Mais do que isso, amparado por tal crença, convencido dessa sua verdade absoluta, esse deus do universo virtual assume um fatalismo e garante utilizar a ilusão da escolha para manipular os indivíduos.

Como afirma Merovíngio, um traficante de informações: não existem escolhas, "a escolha é uma ilusão criada entre os que têm poder e os que não o têm" (MATRIX 
RELOADED, 2003, 01h06m16s). O dominador atua, o dominado acredita que atua na atuação do dominador; o opressor escolhe, o oprimido tem a ilusão de que escolhe, na escolha do opressor. Para comprovar seu argumento, Merovíngio mostra como o ser humano alienado, que não entende os porquês, a causalidade, pode ser uma marionete biológica; e faz isso manipulando, controlando as sensações e necessidades de uma mulher. Nesse filme, concretizam-se ainda mais a imagem e as falas do opressor.

Por fim, o Arquiteto assume acreditar que os oprimidos despertos constituem um crescente risco de desastre para o sistema e, por isso, pretende destruí-los. Descobrimos, nessa cena, que as TVs que apareceram no primeiro filme enquanto o Novo era interrogado e perdia a voz é uma forma de vigília do próprio Arquiteto.

Se no primeiro filme o tema central é o nascimento e, no segundo, a vida; no terceiro, é a morte. É ela que intensifica a importância das escolhas ao trazer para a consciência a certeza de que não se vive para sempre. De que "tudo que tem um começo tem um fim". Enfim, Matrix Revolutions. Mas que revoluções são essas? A primeira é o desenrolar da revelação que o Novo adquiriu no fim do segundo filme. Ele descobre que tem um pouco do velho. A personagem Oráculo afirma-lhe que, na vida, algo se mantém e algo se perde no caminho. Diz que o Arquiteto não enxerga as escolhas que faz, pois acredita que tudo na vida são variáveis em uma equação, que precisam ser balanceadas e provadas. Ou seja, finalizadas, mortas. Afirma que o Smith, de certa forma, é o Novo, um reflexo dele. Que eles estão intimamente conectados. Um é o oposto do outro, o negativo do outro ${ }^{11}$. Smith é o resultado da equação do Arquiteto que tenta se equilibrar em relação a outra variável: o novo. Em suma, o novo guarda em si referências ao velho e o velho traz em si algo do novo. Detalhe: nesse momento, o brinco da Oráculo é o símbolo yin-yang.

Finalmente, dominador e dominado se revelam como faces da mesma moeda. A existência de um depende da existência do outro. É por esse motivo que o oprimido, em sua libertação, deve também libertar o opressor. A liberdade deve ser a liberdade de todos. $\mathrm{O}$ sistema como um todo deve reestruturar-se, e o oprimido não deve se tornar o opressor do opressor (que é o que acontece no filme The Wall, a propósito). Não deve lutar contra ele, mas unir-se a ele para a construção de uma realidade melhor. Assim, como semelhantes, um olhará para o outro - ex-acomodados, agora incomodados e atuantes - e dirá: eppur si muove!

\footnotetext{
${ }^{11}$ De fato, ao assistirmos em retrospecto ao filme com essa informação, percebemos similitudes entre Neo e Smith. Ambos morrem, ressuscitam, crescem em poder, entram em coma, etc., quase que concomitantemente. Alguns possíveis trocadilhos também passam a ser percebidos. Smith se diz um novo homem para o Oráculo, dizem-no que ele é um homem mau... enquanto Neo é chamado ora de homem, ora de máquina. Nas dicotomias homem-máquina, real-virtual, bom-mau, novo-velho, eles realmente se complementam. Verdadeiro yin-yang.
} 
Essa união ocorre no final da trilogia. Smith, o símbolo do velho e do sistema, continua fatalista; e o Novo finalmente percebe que o caminho não é continuar lutando contra o velho. Escolhe libertar-se e libertar ao opressor, tal qual afirma Freire. A Matrix se transforma, o novo torna-se velho. O sistema reestrutura-se em novas relações, e ocorre uma revolução na matriz. Frutos de uma arquitetura ultrapassada, ambos se desfazem. Uma nova ordem implica outras lutas. O velho mudou, outros novos são necessários. Fato anunciado metaforicamente na última cena do filme.

Na última cena, descobrimos inclusive que essa revolução foi conduzida por um jogo da Oráculo, antiga aliada do sistema, mas atual inimiga do Arquiteto. A construção daquela personagem é interessante. Descobrimo-la como uma velhinha, símbolo da sabedoria, que não impõe a verdade, mas incita a buscá-la. Sua atitude caracteriza-se pelo diálogo e pelas perguntas que deixa em aberto. Diz estar interessada em uma coisa: o futuro; e complementa afirmando que a única forma de chegar até ele é em conjunto. Diz, também, acreditar no amor e usa as próprias mãos para transformar o mundo. Não sabe as consequências das escolhas que realiza, mas nem por isso deixa de realizá-las. Elabora um plano, atua e intenta transformar a estrutura da realidade. E consegue, porque, como ela mesma afirma, acreditou.

Não sabemos se os criadores da trilogia pensaram em leituras como essa ao conceber a narrativa. Contudo, é notável que, assim como a filosofia de Freire - que nasce e se fundamenta em suas crenças cristãs, existencialistas e transformadoras - os filmes também permitem a discussão de tais pressupostos (cf. YEFFETH, 2003; IRWIN, 2003). Talvez tais premissas comuns tenham ocasionado a analogia entre os ideais de Freire e a possibilidade de metáfora do elemento cultural elaborado pelos irmãos Wachowski, roteiristas e diretores de Matrix.

\section{I.4 - Práxis: 'A FundaÇão e a Terra'}

Da teoria à pratica, da abstração à ação. Ler o mundo para re-escrever o mundo. A questão que se coloca é: o que contrapor à educação bancária?

Para tanto, convém retomarmos sua prática. Segundo Freire (2005, p. 65), ela se caracteriza principalmente pela narração. Dissertação que subentende um sujeito - o que narra - e vários objetos pacientes - os que ouvem. O real sujeito dessa prática é o professor que despeja conteúdos prontos, intocáveis, retalhos míticos e místicos supostamente definidores da realidade. Uma realidade que, por conta desses conteúdos e dessa postura, parece estática, compartimentada e bem-comportada. Uma realidade parcial, fictícia, muitas vezes distante da 
experiência existencial dos alunos. Em resumo, tal educação parte de uma inexistente dicotomia entre o homem e o mundo. É um homem abstrato, pois isolado do mundo. E um mundo irreal, pois ausente de homens.

Longe da totalidade, os conteúdos perdem a significação. Descontextualizada, descaracterizada, a palavra torna-se oca. É “mais som do que significação” (FREIRE, 2005, p. 66). Um bom exemplo disso são as várias táticas mnemônicas tão famosas na física: sorvete (s $\left.=\mathrm{s}_{\mathrm{o}}+\mathrm{v} \cdot \mathrm{t}\right)$, que mole $(\mathrm{Q}=\mathrm{m} . \mathrm{L})$, etc. $\mathrm{O}$ objetivo é a memorização mecânica, a repetição, $\mathrm{a}$ massificação, e não a compreensão da realidade, o diálogo e a atuação no mundo. Nessa pseudoeducação, bom professor é o doutrinador que narra mais conteúdo, e bom aluno é o que docilmente memoriza mais conceitos. Este, hipertrofiado, anestesiado, amedrontado, se torna um arquivo, um objeto, um hospedeiro, um colecionador de verbetes. Sua palavra é furtada, sua expressão é sacrificada. Sua subjetividade é negada, proibida. Deformado, frustrado em sua potência, demite-se do seu querer.

Sem a possibilidade da transformação e da invenção, da busca, desumanizam-se a educação, o conhecimento e os homens.

Como mudar esse quadro? Para Freire (2005, p. 67), “a razão de ser da educação libertadora está no seu impulso inicial conciliador". O primeiro passo é justamente a percepção da ambiguidade, do equívoco da realidade desumanizante. Ela começa com a derrocada da "absolutização da ignorância", com a queda da visão vertical que possibilita o professor afirmar que a ignorância se encontra toda no outro, no aluno, e que permite este crer que a sabedoria está toda naquele. Inicia-se na tomada de consciência de que o oprimido é sócio-historicamente acomodado e não ontologicamente ignorante, como se subentende na educação bancária. Inicia-se na esperança, não no fatalismo. Na restauração da humanidade esmagada pela injusta "ordem" dominante. Lembrando sempre da necessidade de controlar o revanchismo.

Um dos caminhos para tal derrocada seria o despertar dos dominados, cuja ontológica vocação para ser mais poderia levá-los a perceber a contradição desumanizante da educação bancária e de sua ação apassivadora. Outro caminho seria por intermédio de um professor humanista e revolucionário. Quanto a isso, Freire afirma em uma nota de rodapé:

Não fazemos esta afirmação ingenuamente. Já temos afirmado que a educação reflete a estrutura do poder, daí a dificuldade que tem um educador dialógico de atuar coerentemente numa estrutura que nega o diálogo. Algo fundamental, porém, pode ser feito: dialogar sobre a negação do próprio diálogo (FREIRE, 2005, p. 71). 
Ou seja, para ele:

O que temos de fazer, na verdade, é propor ao povo, através de certas contradições básicas, sua situação existencial, concreta, presente, como problema que, por sua vez, o desafia e, assim, lhe exige resposta, não só no nível intelectual, mas no nível da ação (FREIRE, 2005, p. 100).

A fonte geradora do pensar é a ação sobre o mundo. Não existe linguagem nem pensar sem um mundo a que estejam referidos. O pensar e a linguagem do povo refletem dialeticamente as condições estruturais da "ordem" dominante ${ }^{12}$. Destarte, o cerne dessa pedagogia é sua práxis: a ação e a reflexão dos homens sobre seu mundo para transformá-lo. Com uma postura ativa durante a investigação da situação em que se encontram, os homens se apropriam da temática significativa. Não existe pensar sem querer. Não existe compreensão sem comprometimento. Não existe aprendizagem ou práxis sem engajamento. Toda educação verdadeira, nesse sentido, é autoeducação.

Sua linha axial não é o depósito de conteúdos, mas a problematização dos homens em sua relação com a realidade. Problema encarado como desafio. $\mathrm{O}$ ato cognoscitivo não deve ser realizado somente pelo professor, isolado, enquanto prepara sua aula - caracterizada pela narração e sloganização de sua pesquisa. A realidade não pode ser distante, misteriosa, estranha. O aluno não deve apenas memorizar os esforços cognoscentes transferidos e entregues pelo professor. Não deve permanecer imerso na reflexão que não é sua. Deve emergir sua consciência para inseri-la criticamente na realidade, objetivando-a. Ambos devem desejar e realizar o ato cognoscente em comunhão. Todos contribuem. Desafiam-se, e não se definham. Superam-se.

Para tanto, enfatizemos, o objeto cognoscente não deve ser propriedade do professor, mas alvo constante da reflexão do par educador-educando. Não é uma conquista arrogante em que um impõe sua verdade, mas uma interação humilde onde educador e educando buscam a verdade. Ambos se realizam investigadores críticos, conscientes de que o homem e o mundo não são, estão sendo, irão ser. Investigam o próprio contexto e encontram um pretexto. "Ninguém educa ninguém, ninguém educa a si mesmo, os homens se educam entre si, mediatizados pelo mundo" (FREIRE, 2005, p. 78). Em suma, o homem educando-se está: imerso, emerso, insertado, incerto.

O foco da práxis pedagógica libertadora será o diálogo e, portanto, a palavra. Esta, contudo, não é considerada mero instrumento do diálogo, mas símbolo de sua práxis, definida por suas duas inseparáveis dimensões: a ação e a reflexão. A prática sem a reflexão é um

12 Confessamos que só compreendemos a profundidade dessas afirmações de Freire após a leitura de Wittgenstein e de Bakhtin, e por isso posteriormente abordaremos suas visões sobre a linguagem. 
ativismo mecanicista, ingênuo, burocrático. A reflexão sem a prática é um verbalismo, uma palavreria, blábláblá estéril e inoperante. O diálogo não se esgota na relação eu-tu. Só enquanto práxis, a palavra será autêntica. A palavra torna-se significativa, verdadeira, quando coincide com os atos, quando se sintoniza com eles. Dialética, ela nasce e se concretiza nas relações homens-homens e homens-mundo.

...o pensar do educador somente ganha autenticidade na autenticidade do pensar dos educandos, mediatizados ambos pela realidade, portanto, na intercomunicação (FREIRE, 2005, p. 74).

Só em um diálogo horizontal e humilde a palavra será verdadeira. Só tomando a fé nos homens como uma verdade dada a priori existirá a comunicação. Somente assumindo o homem contextualizado, essencialmente imperfeito, inconcluso, em seu perene estado de busca, a palavra transformará o mundo. Só por meio de um amor valente, coerente com a ousadia da palavra e da ação, pode-se enfrentar a existência como um risco permanente. "Viver em geral é estar em perigo" (NIETZSCHE, 2003, p. 160). Logo, a práxis depende da confiança e da esperança.

\section{I.5 - Metodologia: Universo Temático - Tema Gerador E Tema DobradiÇa}

Na prática, a dialogicidade se inicia em torno do conteúdo dos diálogos, ou seja, do conteúdo programático da educação. Ele não será eleito e prefixado pela visão de mundo exclusiva de um dominador ou uma cúpula de opressores. Educador e educandos, coirmanados, solidariamente escolhem, a partir do contexto, da condição do povo, elementos em um todo desestruturado a ser problematizado.

O primeiro passo é a convocação de alguns representantes voluntários dos educandos para constituir uma equipe que realizará a pesquisa dessa situação concreta, presente, existencial da região onde se instalará o círculo de cultura. Em conversas informais com indivíduos da área, tal grupo coleta e anota, em momentos distintos, dados referentes à maneira de conversar dos homens, suas formas de ser, o comportamento no culto religioso, no trabalho, no lazer, nos esportes, as expressões e linguagens do povo, palavras, sintaxe, a forma de construir o pensamento, as relações entre os homens (FREIRE, 2005, pp. 121:2).

A própria investigação começa a inserir os homens em uma forma crítica de pensar o mundo. Em resumo, como a comunicação eficiente depende de conteúdos significativos, o conteúdo programático inicia-se com a investigação do universo temático do povo (também denominado por Freire de temática significativa) ou o conjunto de seus temas geradores. Vale 
ressaltar que os homens não devem ser encarados como objetos da investigação de algum sujeito.

O que se pretende investigar, realmente, não são os homens, como se fossem peças anatômicas, mas o seu pensamento-linguagem referido à realidade, os níveis de sua percepção desta realidade, a sua visão do mundo, em que se encontram envolvidos seus "temas geradores" (FREIRE, 2005, p. 101).

Dos desafios e inquietações do próprio mundo, educador e educando, impressionados, dialogam sobre suas visões da objetividade em que estão inseridos, sobre suas práxis pessoais. Emergem das relações dialéticas entre os condicionamentos e suas liberdades. Conscientizam-se das situações-limite que se lhes apresentam. Descobrem os vários níveis de percepção de si mesmos e do mundo. Tais visões são impregnadas "de anseios, de dúvidas, de esperanças ou desesperanças que implicitam temas significativos, à base dos quais se constituirá o conteúdo programático da educação" (FREIRE, 2005, p. 97). Podemos dizer que essa pedagogia do oprimido é uma pedagogia do engajamento, pois é uma conscientização dos homens sobre suas próprias atividades e sobre si mesmos. Os temas geradores não existem no homem ou no mundo isoladamente, mas nas relações homenshomens e homens-mundo.

As situações-limite devem ser vistas como desafios, origens das possibilidades; e não pessimistamente, como freios, obstáculos, barreiras insuperáveis. Elas exigem atos-limite, decisões transformadoras da realidade (Álvaro Vieira Pinto apud FREIRE, 2005, pp. 104:5). Superação, ao invés de acomodação. Negação, ao invés de aceitação passiva. Esperança, ao invés de fatalismo. Ao atuar, o homem existe, enfrenta a realidade, real-iza suas atividades produtoras e constrói um "mundo significativo e simbólico, o mundo compreensivo da cultura e da história” (2005, p. 103). Atuação realizada, uma nova realidade se apresenta, exigindo novas respostas transformadoras, incessantemente. O homem é livre em relação aos seus produtos. A emersão dessa dinâmica permite-o perceber o clima, o espírito da época.

Isto é, o conjunto dessas situações-limite, imagens da estrutura da "ordem" vigente, dá forma a uma unidade epocal.

Uma unidade epocal se caracteriza pelo conjunto de idéias, de concepções, esperanças, dúvidas, valores, desafios, em interação dialética com seus contrários, buscando plenitude. A representação concreta de muitas destas idéias, destes valores, destas concepções e esperanças, como também os obstáculos ao ser mais dos homens, constituem os temas da época.

Estes, não somente implicam outros que são seus contrários, às vezes antagônicos, mas também indicam tarefas a serem realizadas e cumpridas. Desta forma, não há como surpreender os temas históricos isolados, soltos, desconectados, coisificados, parados, mas em relação dialética com outros, 
seus opostos. Como também não há outro lugar para encontrá-los que não seja nas relações homens-mundo. $\mathrm{O}$ conjunto dos temas em interação constitui o "universo temático" da época (FREIRE, 2005, p. 107).

É nesse contexto ${ }^{13}$, nessa situação, que os homens decidem, agem, escolhem, refletem e reagem - algumas vezes para manter a ordem, em outras, para subvertê-la. É em correspondência com essas situações que a práxis pedagógica libertadora se fundamenta. Os temas revelam-se pelas situações-limite e as tarefas consequentes são as ações-limite. Elas concretizam o inédito viável, soluções existenciadas, alternativas historicamente demarcadas. Como vemos, os temas geram novas situações e, por isso, se desdobram em novos temas, ampliando-se, renovando-se. Já a educação bancária perpetua as situações-limite como barreira rígida entre o ser e o nada, e não como fronteira transponível entre o ser e o mais ser.

Os temas geradores existem em uma pluralidade reflexa da realidade. Existem os mais gerais e os mais específicos, todos encadeados, vinculados, interpenetrados em problemas histórico-culturais. Freire (2005, p. 109) indica, por exemplo, um tema amplo angustiante: a libertação; e seu oposto: a dominação. Outro tema universal indicado é o subdesenvolvimento dos países do Terceiro Mundo.

A questão que se coloca é: como desenvolver uma compreensão crítica da totalidade se, muitas vezes, nós captamos apenas pedaços, aspectos em que não reconhecemos as interações que constituem a própria globalidade?

Pensando nisso, Freire elaborou uma sequência que se inicia em um contexto popular para, isoladas suas parcialidades, voltar a ele com mais claridade. Contempla, assim, a análise e a síntese, com o indispensável cuidado de não partir estritamente de especificidades periféricas descaracterizadas e incompreensíveis. As questões mais particulares são percebidas criticamente, como dimensões significativo-existenciais da fundamental totalidade. O objetivo não é pulverizar, focalizar a realidade, mas compreender o quadro geral em sua complexidade permanente de vir a ser.

A interpretação do espesso todo não deve ser visto como uma redução do concreto ao abstrato, mas como um pensar dialético sobre a realidade. Para possibilitar essa atitude, o segundo passo da metodologia - após a coleta de dados e enumeração das contradições e situações-limite pela equipe - é a criação de códigos sucintos.

Esses códigos são desenhos, fotografias, curtas dramatizações, pequenos poemas, cartazes, etc., abstrações-representações de certos momentos da situação existencial concreta

\footnotetext{
${ }^{13}$ Tais afirmações de Freire nos lembram a ideia de paradigma de Thomas Kuhn e sua visão da dinâmica da ciência - que nos será muito valiosa posteriormente.
} 
por meio de alguns de seus elementos em interação. Elaborados pelo coordenador e pelos investigadores voluntários auxiliares, permitem uma análise da própria situação durante sua decodificação. Sua elaboração é dialógica, para que as diferentes leituras da realidade empírica, durante a intercomunicação dos membros da equipe, apontem as contradições principais, centrais, e as secundárias da unidade epocal. Constitui-se, assim, a temática significativa da região.

Após a codificação da realidade, a terceira etapa é sua análise; a descrição da representação figurada por todo o círculo de cultura. Nesse momento, uma equipe interdisciplinar ${ }^{14}$ devolve ao povo sua situação existencial codificada como problema que lhe desafia, e não como doação de uma dissertação acabada. Todos auxiliam na decodificação, cisão, análise da situação apresentada, que não lhes parece estrangeira.

No diálogo, as interações entre as partes do todo ficam evidentes, ganhando significação como dimensões resultantes da realidade objetiva e intersubjetiva. Certamente, isso exige uma atenção do educador durante a coordenação do debate. Ele pode inclusive utilizar uma codificação essencial, que acompanhará todo o processo, visível concomitantemente a uma sequência de codificações auxiliares (Gabriel Bode apud FREIRE, 2005, pp. 128:9).

O movimento de ida e volta do pensar, realizado pelos educadores e educandos durante a decodificação, é justamente a análise crítica da situação codificada. Tal postura parte do abstrato ao concreto e deste de volta às partes. $\mathrm{O}$ homem, sujeito, ad-mira seu mundo e reconhece o objeto cognoscível de análise como contorno condicionante em que se encontra com outros sujeitos. Na reflexão que o remete à realidade, desvela-a, supera a abstração, e o movimento de análise e síntese se realiza. Parte assim da 'doxa' (conhecimento desarmado, opinião imperfeita - o que não quer dizer falsa) ao 'logos' ou 'episteme' (outro nível gnosiológico).

A realidade, codificação sui generis e viva, deixa de ser espessa, difusa, intangível, para ser palco de suas escolhas e ações, de sua ação cultural e histórica de caráter libertador. Sua maneira de visualizar a objetividade se transforma. Muda sua consciência da realidade e sua autoconsciência. Sua racionalidade atinge outros níveis. Na ação, pensando o seu pensar, percebe sua percepção anterior, realizando uma meta-análise de seu próprio processo, de sua existência. Teoria e prática simultaneamente se fundem na práxis. Só assim ela se faz plena. Impactado, o homem se altera, aprende. Desnuda-se de seus mitos (e este, como já dissemos, pode ser um processo doloroso).

\footnotetext{
${ }^{14}$ Para Freire, a equipe interdisciplinar deve ser composta, inclusive, de um psicólogo e um sociólogo,
} responsáveis por analisar as reações do povo durante o processo, usando para isso a gravação dos debates. 
Estando a totalidade presente no código, sendo ele plural e inclusivo, permitindo o surgimento de outros temas (leque temático), o indivíduo, durante o diálogo, explicita sua consciência real, sua visão de mundo. Ao se comunicar, revela sua estética, lapida sua visão da estrutura em que se encontra. Na tônica dos debates, amplia seus horizontes. Novas percepções, novos conhecimentos, novas ações. Seu trabalho, seu labor, é co-labor-ação.

Nesse ínterim, as situações-limite, históricas, emergem, evidenciando as possíveis ações-limite, o inédito viável, a concretização da práxis humana, sua intencionalidade, a inserção do sujeito na cultura. Como bem percebe Freire, se um grupo de indivíduos não expressa concretamente uma temática geradora, isso não significa a inexistência da temática, mas a presença de um tema dramático: o silêncio, o mutismo, o indiferentismo, a acomodação frente às situações-limite. Cabe ao investigador instigar os indivíduos, problematizando a situação em que se encontram e as respostas emitidas durante o diálogo.

Terminada a decodificação no círculo, inicia-se a quarta etapa: o estudo sistemático e interdisciplinar das gravações, das afirmações realizadas, arrolando os temas implícitos ou explícitos nas falas. Tais temas são classificados em um quadro geral. Revelam, dessa forma, seu lugar, seu domínio, sua especificidade em relação ao todo. Mas não são tratados esquematicamente, longe da visão geral. Não são esvaziados de suas riquezas por abordagens estreitas de especialistas.

Suponhamos o tema poluição. Ele pode ser analisado do ponto de vista da política, da economia, da química, da climatologia, etc. A função dos especialistas da equipe é, após a delimitação temática, "reduzir" o tema em núcleos fundamentais, organizados em uma sequência de unidades de aprendizagem, dando a visão geral do tema "reduzido". Tais unidades podem ser sistematizadas, por exemplo, na forma de ensaios e projetos a serem discutidos pelos educadores-educandos e educandos-educadores. Com isso, o povo irá conhecer e criticar o pensamento do intelectual. Não é só ao profissional, ao expert, que é permitido ter uma visão de mundo. Para tanto, mais uma vez, o resultado da "redução" deve ser elaborado na forma de uma codificação.

O melhor canal para isso deve ser escolhido pela equipe, e compreende várias possibilidades: pode ser um canal visual (pictórico ou gráfico), auditivo, táctil; ou pode ainda ser uma composição desses canais simples. "Na 'codificação' se procura re-totalizar o tema cindido, na representação de situações existenciais" (FREIRE, 2005, p. 135). Reportagens de jornais ou revistas, capítulos de livros, etc., podem ser utilizados como ensejo para a discussão. Porém, sempre como problemas a serem decifrados, nunca como conteúdos a serem depositados. Problemas que provoquem o povo a participar, a tomar parte, a fazer parte 
da reconstrução da sociedade. Sem a ação, o pensamento e o conhecimento tornam-se mera abstração.

A equipe pode, até mesmo, incluir novos temas que considerar importantes, mas que por ventura não aparecerem na interação com o povo. Sempre informando o porquê da presença desses novos tópicos. Eles são denominados temas-dobradiças, e corporificam a dialogicidade desta pedagogia, pois revelam a participação, a voz dos educadores no processo. A função desses temas-dobradiças pode ser, por exemplo, facilitar "a compreensão entre dois temas no conjunto da unidade programática, preenchendo um possível vazio entre ambos"; ou ainda, eles podem conter em si "as relações a serem percebidas entre o conteúdo geral da programação e a visão do mundo que esteja tendo o povo" (FREIRE, 2005, p. 134).

Um exemplo de tema-dobradiça seria o conceito antropológico de cultura. Segundo Freire, a problematização desse tema pode ser fundamental para que os indivíduos compreendam o papel do homem no mundo e com o mundo, como seres de transformação e não de adaptação. Dessa forma, essa inserção relaciona a visão que o povo desenvolveu do programa com sua concepção geral de mundo (2005, p. 134).

No caso de toda a investigação inicial não ser possível, justamente a inserção desse tema poderá ser a precursora da atuação horizontal do educador que, ao mesmo tempo, realizará a investigação temática por meio do diálogo com o povo. É um tema-dobradiça prenunciador que potencialmente instigará vários temas geradores.

A cargo de esclarecimento, vale frisar que tal metodologia não é construtivista, uma vez que o educando não irá percorrer, reconstituir, adivinhar todo o caminho da edificação de um conceito, de um experimento, etc. (FREIRE, 1992, p. 52). Na verdade, incitado, ele irá reconhecer um mito decodificando uma representação. Posteriormente, por meio das unidades de aprendizagem, ele estudará a visão de outras pessoas sobre o assunto, sempre criticando respeitosamente tais leituras de mundo. 


\section{Capítulo II \\ Física É Cultura}

$O U$

\section{'AdMIRÁVEl Mundo Novo'}

- Esses primeiros experimentadores - dizia o D.I.C. - seguiram um caminho errado. Acreditavam que se podia fazer da hipnopedia um instrumento de educação intelectual...

(Um menino, adormecido sobre seu lado direito, o braço direito estendido, a mão direita pendendo molemente por sobre a beira da cama. Através de uma abertura redonda e gradeada na parede de uma caixa, uma voz fala baixinho. "O Nilo é o mais comprido dos rios da África, e o segundo em comprimento de todos os rios do globo. Conquanto não atinja o comprimento do Mississipi-Missouri, o Nilo está em primeiro lugar entre todos os rios quanto ao comprimento da bacia, que se estende por 35 graus de latitude..."

No café da manhã, no dia seguinte:

- Tommy - pergunta alguém - você sabe qual é o rio mais comprido da África?

Sinal negativo com a cabeça.

- Mas você não se lembra de uma coisa que começa assim: "O Nilo é..."?

- O Nilo-é-o-mais-comprido-dos-rios-da-África-e-o-segundo-em-comprimentode-todos-os-rios-do-globo... - As palavras saem em torrente. - Conquanto-não-atinja...

- Muito bem, qual é o rio mais comprido da África?

Os olhos ficam inexpressivos.

- Não sei.

- Mas o Nilo, Tommy!

- O-Nilo-é-o-mais-comprido-dos-rios-da-África-e-o-segundo...

- Então, qual é o rio mais comprido, Tommy?

Tommy desata a chorar.

- Eu não sei - responde entre lágrimas.)

- Essas lágrimas, - esclareceu o Diretor, - desanimaram os primeiros pesquisadores. As experiências foram abandonadas. Não se fizeram mais tentativas para ensinar o comprimento do Nilo às crianças durante o sono. Muito acertadamente. Não se pode aprender uma ciência sem saber do que se trata.

Aldous Huxley, 1980, pp. 23:4.

Neste capítulo, continuaremos as denúncias de Freire à hipnose do 'sono-ensino', mas agora voltados especialmente ao ensino de Física por meio das críticas de João Zanetic. Seguiremos seus diálogos com filósofos, historiadores e sociólogos da ciência, pois eles elucidarão nossas análises posteriores da ficção científica. 
Se existem mitos culturais que aprisionam nossas mentes e se a educação autêntica se faz como ação cultural, a questão primordial que se nos coloca é: física é cultura?

\section{II.1 - Jỗo ZANETIC: FíSICA TAMBÉM É CULTURA!}

A física também é cultura. A física também tem seu romance intrincado e misterioso. Isto não significa a substituição da física "escolar" por uma física "romanceada". O que desejo é fornecer substância cultural para esses cálculos, para que essas fórmulas ganhem realidade científica e que se compreenda a interligação da física com a vida intelectual e social em geral (ZANETIC, 1989, p. VI).

Zanetic revela-nos, no prefácio de sua tese de doutorado intitulada Física também é cultura, as experiências que influenciaram os rumos de sua pesquisa. Além disso, durante todo o texto, ele exemplifica suas afirmações com trabalhos de seus alunos nos anos que ministrou as disciplinas Instrumentação para o ensino de física e Evolução dos conceitos da física no Instituto de Física da Universidade de São Paulo.

Em sua avaliação crítica do ensino/aprendizado de física, amparado pelas leituras do próprio Freire, e de filosofia, história e sociologia da ciência, Zanetic identifica algumas falhas, deturpações que permitem distinguir a física enquanto ciência da física algorítmica e pobre cobrada no vestibular e ensinada nas escolas. Infelizmente, tais denúncias continuam válidas (MARTINS, 2009). Fossilização anacrônica que nos deixa perplexos (MENEZES, 2009, p. 27). De forma bem sucinta, são elas:

i. A física escolar se resume a uma lastimável operacionalização reducionista, distante da vivência, da história e da cultura do povo, caracterizada pela "mera apresentação de um sumário de conceitos, leis, grandezas físicas e unidades de medida, seguidos de uma extensa lista de exemplos resolvidos e exercícios propostos" (ZANETIC, 1989, p. 15).

ii. Há uma ausência de experimentos, tanto os que trazem esclarecimentos para a teoria como os ligados à vida cotidiana.

iii. Ignoram-se as mudanças epistemológicas. Quando presente uma abordagem desse tipo, ela resume-se a uma visão ingênua do indutivismo ou do positivismo.

iv. Está omitida a história da ciência; tanto a internalista (a história das leis e conceitos) quanto a externalista (que relaciona a ciência com o contexto sócio-históricocultural). Quando presente, ela é episódica e caricatural.

v. "A física é apresentada como um ramo do conhecimento neutro, apolítico e desligado do cotidiano" (idem, p. 17). 
vi. Apenas a física clássica (térmica, mecânica, eletromagnetismo e ótica) aparece nas aulas e livros didáticos. Relatividade e quântica não são mencionadas.

Para ele, tais distorções são consequências da formação lacunar dos licenciados em física, cuja graduação deveria incluir discussões epistemológicas, sociais e históricas sobre o processo de construção da ciência, em vez de apresentá-la apenas como um castelo já construído, infalível, de produtos comportados, estáveis e bem-delimitados.

Com o intuito de ressuscitar a física escolar com todas as vicissitudes características de uma ciência, como organismo vivo, dialeticamente capaz de explicar e transformar a realidade, ele apresenta e compara diferentes filósofos, historiadores e sociólogos da ciência. Como pretendemos apresentar a ficção científica justamente como um meio de problematizar os mitos sobre a ciência que permeiam nossa sociedade, perpassaremos tais considerações.

\section{II.2 - Pout-PourRi Filosófico}

Realizaremos uma colcha de retalhos de diferentes filósofos da ciência. Partiremos de uma discussão sobre a construção da ciência e a relação entre o conhecimento dito científico e a verdade. Aproveitaremos o ensejo para revelar outra de nossas leituras de Matrix. O ímpeto para tal interpretação foi a descoberta do nome de dois filósofos da ciência no "universo" do filme: David Hume e Karl Popper. Existem outras leituras baseadas em outros filósofos tais como Descartes e Kant (cf. IRWIN, 2003; YEFFETH, 2003). Resolvemos seguir outro caminho para não sermos repetitivos e maçantes. Nosso objetivo é problematizar o método científico, pois cremos que algumas visões sobre ele acarretam maldades sociais, além do desserviço que fazem na implementação da ciência enquanto cultura.

\section{II.2.1 - Método Científico ou Mito Científico?}

"Você já teve um sonho, Neo, que tinha certeza de que era real? E se você não conseguisse acordar desse sonho? Como saberia a diferença entre o mundo dos sonhos e o mundo real?" (MATRIX, 1999, 00h31m32s).

Considere o seguinte pressuposto: a possibilidade de Matrix (NIXON, 2003, p. 63). Será que existe uma possibilidade, mínima que seja, de que, enquanto você acredita estar lendo este texto, na verdade seu corpo esteja imerso em tanques enquanto serve de pilha para máquinas? Partindo da premissa de que tal ideia é plausível, tentemos responder à pergunta: 
como provar que este mundo em que vivemos é Real? ${ }^{15}$ Esta pergunta possui, no mínimo, duas premissas: a) existe A Realidade Absoluta e b) é possível conhecê-la.

a) Será que existe uma realidade absoluta? No contexto do filme, se não existisse, poderíamos imaginar a existência de uma realidade virtual dentro de outra, indefinidamente. Acreditamos ser possível explicar todos os eventos da trilogia sem esta ideia. Já no contexto da ciência isso leva a outra pergunta: faz sentido estudar física se não existe 'A Realidade'? Mário Bunge (1973) afirma que não, que é insensato elaborar modelos sobre a natureza se não acreditarmos que ela existe. De qualquer forma, seria interessante continuar o diálogo partindo de um pressuposto: tanto no universo do filme quanto no nosso existe 'A Realidade Absoluta'.

b) É possível ao ser humano conhecer 'A Realidade'? Ou, extrapolando a pergunta: é possível ao ser humano conhecer algo? Existe uma corrente filosófica que afirma não podermos ter certeza absoluta sobre assunto algum. Para os céticos, "não podemos saber com certeza que o mundo externo existe" (ERION; SMITH, 2003, p. 52). Bacon (1999, p. 61) afirmava que divagações como essas retardavam o progresso da ciência.

\section{II.2.2 - FRANCIS BACON (1561 - 1626)}

Para ele, não só existe uma verdade última, por excelência, como é possível ao ser humano conhecê-la. Mais do que isso, ele insistia que tal conhecimento deveria possuir utilidade prática, contribuindo para aliviar e melhorar a condição humana. Daí sua máxima: "saber é poder" conhecimento desenvolvido até então? Como proceder para não reincidirmos nos mesmos erros? Os erros, Bacon ilustra por meio de ídolos. O 'como proceder a partir de então', ele responde criando um método.

Retornemos à pergunta chave, mudando o status da pergunta de acordo com as ideias de Bacon: como provar 'cientificamente ${ }^{, 17}$ que este mundo em que vivemos é Real? Segundo

\footnotetext{
${ }^{15}$ Além de exemplificar o diálogo epistemológico, nosso objetivo neste texto também é mostrar que, na tentativa de responder esta pergunta chave nascida em uma obra de Ficção Científica e utilizando elementos da própria obra, nos depararemos com várias questões da Filosofia da Ciência; o que, a nosso ver, ilustra que a conexão entre as duas FCs vai além da coincidência das siglas.

${ }^{16}$ Podemos levantar alguns questionamentos sobre as ideias de Bacon. Qual a relação entre ciência, tecnologia e sociedade? Será que conhecimento gera poder, e vice-versa? A ciência pode ser usada para o mal? De quem é a responsabilidade? Tais discussões podem ser realizadas por meio de Matrix: foram várias as consequências da invenção da Inteligência Artificial para a sociedade (como mostra o episódio de Animatrix: O Segundo Renascer), e o poder das máquinas cresceu após elas aprenderem a manipular os sinais elétricos do sistema nervoso humano, a ponto de usarem o homem como fonte de energia.

${ }^{17}$ A palavra cientista foi cunhada séculos depois, mas cremos que ela resume bem o propósito de Bacon.
} 
ele, o primeiro passo é enumerar as possíveis fontes de erro, para evitá-las. Assim, resta-nos a pergunta: o que nos atrapalharia a enxergar A Realidade?

Isto nos leva a outra pergunta: como interagimos com o mundo? Por meio dos sentidos. A pergunta mais óbvia é: os sentidos são infalíveis? Bacon diria que não, pois as percepções humanas são características unicamente da nossa espécie. Hoje, afirmamos que os homens enxergam certas cores e, eventualmente, outros animais enxergam outras. Entretanto, Bacon entendia que a natureza é uma só. Ela não mudaria enquanto diferentes animais tentassem interpretá-la. Destarte, ciente que as sensações humanas não são confiáveis, nomeou problemas como este de ídolos da tribo.

Em suma, se quisermos provar que este mundo em que vivemos é Real, não devemos nos deixar enganar por excesso de confiança em nossos sentidos. Vide, no caso de Matrix, a enorme quantidade de pessoas que acreditavam viver em um mundo real enquanto estavam sendo ludibriadas pelas suas sensações ${ }^{18}$.

Mas este não é o único problema. Existe um outro inerente não mais à espécie como um todo, mas à visão de mundo de cada pessoa, ou seja, suas crenças pessoais. Para Bacon, interpretamos novos eventos de acordo com nossa experiência de vida até então (como os personagens da alegoria da caverna de Platão), e ele denominou tais deslizes de ídolos da caverna. Logo, se intentarmos provar que este mundo em que vivemos é Real, devemos nos desapegar de nossa crença de que ele é real, pois esta tautologia nada prova. Se alguma pessoa presa à Matrix gritasse: “este mundo é real!", além de estar agindo irracionalmente, o que não é considerado por Bacon uma atitude "científica", continuaria servindo de pilha para máquinas.

As "antecipações da natureza" ou "regras falseadas de demonstração" seriam os ídolos do teatro. De tão mergulhada na sua própria crença, uma pessoa pode elaborar experimentos tendenciosos que impõem o resultado esperado à natureza ainda não observada. Um exemplo seria concluirmos que este mundo é real porque todos os livros que lemos até então sempre afirmaram que este é o mundo real. Tal antecipação acaba nos iludindo em nossa própria crença. Quando Bacon descreve este tipo de ídolo, ele também se refere às universidades da época, que insistiam em discutir se algo podia ser conhecido ${ }^{19}$, em vez de

\footnotetext{
${ }^{18}$ É interessante notar, inclusive, como a questão dos sentidos é propositalmente trazida para a consciência pelos roteiristas do filme. Em diversas cenas, as personagens falam do cheirar, do ouvir, do ver, do saborear, do tocar. Em diferentes cenas elas não apenas falam, mas tocam, degustam, ouvem... O filme em si é uma provocação aos sentidos do telespectador por meio dos efeitos especiais dignos do Oscar.

${ }^{19}$ A pergunta que fica é: será que, se todos os humanos tivessem aceitado as ideias dos céticos, sofistas, etc., teríamos o desenvolvimento científico e tecnológico que temos hoje? E, por outro lado, se ao invés do pragmatismo de Bacon tivéssemos seguido uma linha mais contemplativa, como estaria a sociedade?
} 
olhar para a Natureza. Para ele, mesmo quando a experimentação ocorria, era feita ao acaso, sem um rigor metódico. Sobre esta supervalorização do conhecimento presente nos livros dos antigos, ele afirma: “a verdade é filha do tempo, não da autoridade” (BACON, 1999, p. 66).

Por fim, existem também os problemas da comunicação e os relacionados à ambiguidade das palavras, que Bacon uniu sob o nome de ídolos do foro. Por exemplo, poderíamos dizer a alguém: "Você está vivendo no mundo dos sonhos!", e esta pessoa se imaginar em uma padaria, rodeada por deliciosos pãezinhos recheados com goiabada. Talvez por isso Morpheus diga a Neo: "Não se pode dizer a ninguém o que é a Matrix. Você tem de vê-la por si mesmo" (MATRIX, 1999, 00h28m42s).

Para Bacon, estando o pesquisador ciente destes possíveis deslizes, e "cuidando-se o mais que possa", ele poderia limpar a mente e, finalmente, iniciar um progresso sistêmico no estudo da natureza. Mas como desenvolver um conhecimento verdadeiro? Para ele, a resposta é seu método: por meio de extensa experimentação e da verdadeira indução.

Ele pregava a catalogação de todos os experimentos relativos ao assunto escolhido separados em algumas Tábuas de Investigação (tábua da presença ou afirmação; tábua da ausência ou negação e tábua de graus ou de comparação). Entretanto, para nós, o que importa são os pressupostos desse método: ele parte da premissa que existe 'A Realidade'; que é possível conhecer 'A Verdade'; que o método para fazê-lo é cumulativo e linear, iniciando-se na catalogação de vários experimentos (a ciência começa na observação minuciosa da Natureza, o que diminui o risco de aparecer algum erro subjetivo); que destas extensivas enumerações, um único ser humano analisando-as todas descobre um padrão; e que este padrão pode ser considerado uma lei natural. Logo, para Bacon, é legítimo induzir uma lei a partir de um padrão repetitivo em experimentos realizados inúmeras vezes sob as mais diversas condições.

Voltemos à pergunta chave: como provar cientificamente que este mundo é Real? Seguindo os passos de Bacon, escolhemos um assunto: o estudo da Realidade. Assim, se tencionamos saber se o universo em que vivemos é Real, deveríamos iniciar catalogando todas as experiências relacionadas a este tema. Enfim, nossos sentidos parecem indicar que nossas experiências, durante toda a nossa vida, ocorreram no mesmo universo (e são várias experiências nas mais variadas e inimagináveis condições); temos noção de que saímos de um mundo dos sonhos quando acordamos (e isto também ocorreu em diversas ocasiões diferentes: acordar na nossa casa, ou na casa da vovó; acordar sozinho ou acompanhado; acordar naturalmente ou irritado com o despertador, etc.); e temos noção de que voltamos para o mundo real quando paramos de jogar videogame, saímos do cinema ou de um planetário. 
Ou seja, temos incontáveis experiências onde nossos sentidos indicam que estamos ou voltamos - para o mundo real. Deste modo, para Bacon, é legítimo induzir que este mundo em que vivemos é Real, pois repetimos várias experiências nas mais diversas condições. Na verdade, é intrigante que toda essa reflexão baconiana seja feita intuitivamente pela maioria das pessoas. Se perguntássemos para as pessoas na rua: esse mundo em que você vive é real? Acreditamos que boa parte responderia: é óbvio! E fariam isso amparadas por milhares de experiências que os seus sentidos lhes proporcionaram em todos os anos de suas vidas. Mas isso garante alguma coisa? Na opinião de

\section{II.2.3 - DAVID HUME (1711 - 1776):}

Apesar de somente um bobo ou um louco - e ninguém mais! - pretender discutir a autoridade da experiência ou rejeitar este grande guia da vida humana, é lícito, contudo, admitir que um filósofo tenha ao menos a curiosidade de examinar qual é o princípio da natureza humana que dota a experiência de tão forte autoridade... (HUME, 1999, p. 56).

Ele irá argumentar que não existe raciocínio lógico que demonstre que "o futuro estará em conformidade com o passado", como supomos das nossas conclusões experimentais (HUME, 1999, p. 56). De fato, ele afirma que as relações de causa e efeito que percebemos no mundo não podem ser provadas logicamente, uma vez que "todo efeito é um evento distinto de sua causa" e não pode ser descoberto nela.

Mesmo supondo que as faculdades racionais de Adão fossem inteiramente perfeitas desde o primeiro momento, ele não poderia ter inferido da fluidez e da transparência da água que ela o afogaria, ou da luz e do calor do fogo, que este o consumiria. Nenhum objeto jamais revela, pelas qualidades que aparecem aos sentidos, tanto as causas que o produziram como os efeitos que surgirão dele; nem pode nossa razão, sem o auxílio da experiência, jamais tirar uma inferência acerca da existência real e de um fato (HUME, 1999, p. $50)$.

Ou seja, a relação causa-efeito é uma inferência que fazemos de nossas experiências, mas tal inferência não garante sua veracidade. Entretanto, ainda que esta demonstração lógica não exista, é psicologicamente reconfortante ao ser humano a crença em relações de causa e efeito. Assim, "o costume, é pois, o grande guia da vida humana” (HUME, 1999, p. 63).

Destarte, para Hume, um dos pressupostos do método de Bacon possui problemas: não pode ser demonstrada logicamente a legitimidade da indução. Em uma das primeiras cenas do jogo Enter the Matrix (Atari/Shiny Entertainment) - lançado concomitantemente aos últimos filmes da trilogia -, Ghost e Niobe conectam-se à Matrix com o intuito de recuperar 
um recado deixado por outros rebeldes. Assim que a realidade virtual é iniciada ao redor deles, Ghost começa a verificar se suas armas estão carregadas. Abismada com tal ato, Niobe o questiona:

Niobe: Por que você está fazendo isso?

Ghost: Fazendo o quê? - enquanto verifica se o revólver está carregado.

Niobe: Verificando suas armas.

Ghost: Nunca se sabe. - ele afirma, enquanto verifica outro revólver.

Niobe: É um programa. Elas são carregadas todas as vezes exatamente da mesma maneira.

Ghost: Hume nos ensina que não importa quantas vezes você largue uma pedra e ela caia no chão, nunca se sabe o que vai acontecer da próxima vez que você a largar. Ela pode cair no chão, mas por outro lado, pode voar até o teto. Não se pode provar o futuro pela experiência passada.

Niobe: Então?

Ghost: Então nunca se sabe (Enter the Matrix, 2003) ${ }^{20}$.

Mas, quais as consequências deste problema da indução para nossa conclusão anterior sobre A Realidade? De maneira simples: ele reduz nossa certeza de que estamos no mundo real a uma crença de que estamos no mundo real. Isso, no mínimo, deveria nos deixar mais humildes quanto ao alcance de nossos sentidos e de nossa razão. Nesse ponto, podemos perguntar: se o método de Bacon, que parecia tão lúcido, não garante a veracidade das conclusões, como provar que este mundo é Real? A questão agora é: será que é possível provar cientificamente que este mundo é Real? De fato, lembremos que os pressupostos de Bacon eram: existe A Realidade, e é possível conhecê-la. Nesse momento, um "popperiano" se perguntaria: será? ${ }^{21}$

\section{II.2.4 - KARL POPPER (1902 - 1994)}

Popper possui uma visão de ciência diferente daquela de Bacon. Ele reconhece a ciência não como dona de uma verdade absoluta e incontestável, mas como um conjunto de modelos. Isso não garante que os modelos sejam A Realidade. Para Popper, o papel do cientista não é descobrir a verdade observando a Natureza, mas especular o quanto sua criatividade permitir, e deduzir as consequências de suas conjeturas, exprimindo-as em alguns enunciados. Só nesse momento as observações e os experimentos apareceriam - e no papel de

\footnotetext{
${ }^{20}$ Não pretendemos que o professor jogue o videogame para utilizar Matrix em aula. Entretanto, achamos útil mostrar que os criadores do universo Matrix estavam preocupados com pontos filosóficos como esse.

${ }^{21}$ Convém afirmar que não estamos seguindo estritamente argumentações dos próprios filósofos. Na verdade, estamos usando certa licença epistemológica para, a partir do filme, suscitar algumas questões que achamos interessantes para estabelecer uma ponte entre a ficção científica e a filosofia da ciência.
} 
juízes da validade desses enunciados. Se o enunciado não for refutado, ele passa, momentaneamente, a ser aceito como lei (e que seja eterno enquanto dure).

Logo, para Popper (2006, p. 31), “o trabalho do cientista consiste em elaborar teorias e pô-las à prova". Pensando assim, ao invés de afirmarmos 'A Realidade existe e é possível conhecê-la', diríamos 'se A Realidade existir, podemos nos aproximar desta verdade excluindo com certeza aquilo que não é verdade'. Tais premissas podem parecer menos dignas de um método que se diga científico, mas o lado positivo é que o método desenvolvido por Popper se sustenta pela lógica, pois não existe um problema da dedução. Pensando desta maneira, não faz mais sentido perguntarmos se é possível provar cientificamente que este mundo é real, se entendermos que provar cientificamente signifique mostrar uma verdade incontestável. Para Popper é justamente o fato de ser contestável que caracteriza uma teoria como sendo científica.

Com isso, para ele, o método que guiaria o trabalho dos cientistas seria representado pelas seguintes etapas (ZANETIC, 2006, p. 33):

1. Existência de um problema a ser resolvido;

2. Procura de soluções para o problema através da elaboração de várias hipóteses tentativas e a escolha de uma delas segundo o critério de aceitar aquela que apresenta maior grau de possibilidades de refutação;

3. Dedução de conseqüências dessa hipótese;

4. Critério de refutabilidade em ação: a hipótese é testada, isto é, procura-se refutá-la buscando contra-exemplos significativos;

5. Passando por esse teste, isto é, na ausência de refutação, a hipótese se transforma na nova teoria;

6. Em caso de uma descoberta refutadora ou de uma dedução não confirmada, voltamos ao estágio inicial.

Ou seja, a teoria científica deve ser refutável, mas não refutada.

Façamos isso. Vamos conjeturar que a Possibilidade de Matrix é um absurdo, isto é, que não existe outro mundo, que não é possível separar mente de corpo, deixando este em um tanque gosmento enquanto nossa mente fica sendo enganada por meio de impulsos elétricos no cérebro ${ }^{22}$. Feito isso, devemos nos perguntar: qual a dedução lógica dessa afirmação? Se não existe a Matrix, não é possível que uma pessoa fique vagueando entre os dois mundos, uma vez que um deles não existe. Será que há alguma experiência que falsifique essa dedução? Acreditamos que não. Conhecemos alguém que foi passear por um mês no mundo

\footnotetext{
${ }^{22}$ Podemos perguntar: é possível reduzir a existência humana a sinais elétricos interpretados pelo cérebro? - o que, diga-se de passagem, é uma premissa do filme. Será que as máquinas podem simular toda uma existência apenas usando impulsos elétricos estimulados na região correta do cérebro, ou o ser humano é mais do que isso? O que é ser mais do que isso? É dizer que existe alma, por exemplo?
} 
real e voltou trazendo as novidades? Não. Conhecemos algum visitante que tenha vindo do outro mundo? Não.

Alguém poderia contestar, afirmando já ter visto uma pessoa se transformar em Agente Smith. O que esta pessoa pode estar querendo dizer é: por que devemos descartar a hipótese quando ela não é confirmada pela observação? Qual o problema em descartar a observação? A dúvida é legítima, e Popper tinha noção disso. Cremos que a questão aqui é: é possível repetir a experiência? É possível verificar uma pessoa se transformando no Agente Smith novamente? Se não é esse o caso, parece que a conclusão mais pertinente é aceitar, pelo menos com as experiências mais confiáveis que possuímos até o momento, que a ideia de que uma Matrix seja absurda parece plausível. E lembremos, isso não prova que a ideia de Matrix é impossível. Se aceitarmos a visão de Popper, podemos afirmar que esta conclusão é científica.

Mas, e no próprio filme, alguém segue o método de Popper? Na verdade, por mais absurda que toda essa discussão possa parecer, existe uma personagem do filme que possui o nome desse filósofo. É o garoto que insiste em afirmar que Neo o salvou, no início de Matrix Reloaded. Para descobrir isso, é necessário assistir ao episódio Era uma vez um garoto do Animatrix, que conta justamente a história de como ele se libertou da Matrix.

Nós nos questionamos o seguinte: por que os roteiristas da trilogia deram esse nome ao garoto? Uma das razões pode ser a seguinte: Popper acreditava que, quanto mais ousadas as hipóteses, melhores elas seriam, pois existiria uma maior possibilidade de refutá-las. O garoto formulou ousadamente a hipótese de que o mundo em que vivia não era real e tentou comprová-la de uma forma não recomendada: suicidando-se (ao fugir de agentes) confiando que assim chegaria ao mundo real. Mesmo Neo e Trinity ficam fascinados com a façanha do garoto. Mas a fascinação maior deve surgir quando, ao assistir à cena de seu enterro na Matrix, percebemos em sua lápide o nome: Michael Karl Popper.

Todavia, não nos importa a razão da escolha do nome; o que nos interessa neste momento é que podemos utilizar o filme para debater filosofia da ciência ao tentar discutir sobre a Realidade do nosso mundo. Assim, para nós, como ninguém voltou do outro mundo dizendo que este em que estamos não é real, podemos dizer: este mundo é Real, até que provem o contrário $^{23}$.

Até agora aplicamos os métodos de Bacon e Popper, que tinham como finalidade prescrever, passo a passo, o trabalho de um cientista. Seriam teorias para guiar a formulação

\footnotetext{
${ }^{23}$ Não entramos, aqui, no mérito de uma questão fundamental, que o próprio filme levanta: como definir o que é Real? Não sabemos tal resposta. Até agora, podemos dizer que confiamos no nosso método.
} 
das teorias. Mas os cientistas seguem tais passos? Quando um pesquisador requisita financiamento, ele declara que tentará refutar a teoria em vigor?

\section{II.2.5 - THOMAS KUHN (1922 - 1996)}

Ainda que defensores de ambos os métodos anteriores consigam mostrar casos em que eles pareçam ter sido utilizados, Thomas Kuhn - olhando criticamente para a história da ciência - verificou que isso não era muito comum. Ele constatou que os pesquisadores nem sempre seguiam determinados métodos, ou seja, que os indivíduos chamados cientistas não trabalhavam de acordo com etapas existentes em alguma tabuleta prescritiva postada sobre a mesa ou pregada na parede do laboratório.

De fato, se compreendermos que a história nem sempre é contada de maneira imparcial, parece-nos razoável desconfiar dos exemplos de aplicação dos métodos científicos na história da ciência narrada pelos filósofos que praticam uma reconstrução racional dessa história. Desse modo, ao invés de formular mais uma teoria prescritiva de como a ciência deveria ser desenvolvida, Kuhn vai olhar para o passado e formular uma teoria descritiva de como a ciência ocorreu até então.

Fato notável é que ele percebeu que, mesmo com as críticas de Bacon à educação ${ }^{24} \mathrm{e}$ a influência deste no pensamento positivista que acabou largamente influente culturalmente, a filosofia de ensino continua a mesma, na maioria das escolas, até hoje: verdades incontestáveis são ensinadas aos estudantes que aprendem a articular essas teorias tidas como infalíveis.

Entretanto, Kuhn afirma que, mesmo dessa maneira, ocorre um progresso, uma melhoria da ciência quando a insistência no uso de uma teoria leva a sua articulação. Desse modo, não só a teoria dominante seria ensinada aos estudantes, por meio de seus conceitos e princípios, bem como todo o instrumental experimental e matemático, as metodologias e filosofias, os valores e as crenças desta teoria. Ele denominou esse conjunto de ensinamentos, que os estudantes aprenderiam a manipular, de paradigma. Em suma, o paradigma "fornece

\footnotetext{
24 "Por outro lado, nos costumes das instituições escolares, das academias, colégios e estabelecimentos semelhantes, destinados à sede dos homens doutos e ao cultivo do saber, tudo se dispõe de forma adversa ao progresso das ciências. De fato, as lições e os exercícios estão de tal maneira dispostos que não é fácil venha a mente de alguém pensar ou se concentrar em algo diferente do rotineiro. Se um ou outro, de fato, se dispusesse a fazer uso de sua liberdade de juízo, teria que, por si só, levar a cabo tal empresa, sem esperar receber nenhuma ajuda resultante do convívio com os demais. E, sendo ainda capaz de suportar tal circunstância, acabará por descobrir que a sua indústria e descortino acabarão por se constituir em não pequeno entrave à sua boa fortuna. Pois os estudos dos homens, nesses locais, estão encerrados, como em um cárcere, em escritos de alguns autores. Se alguém deles ousa dissentir, é logo censurado como espírito turbulento e ávido de novidades." (BACON, 1999, p. 73).
} 
problemas e soluções modelares para uma comunidade de praticantes de uma ciência" (KUHN, 1975, p. 13). Nesse caso, os cientistas não buscam saber mais, mas apenas confirmar aquilo que já sabem.

Os futuros cientistas são treinados a resolver problemas cujas soluções já estão dadas pelo paradigma dominante. Kuhn compara isso à montagem de quebra-cabeças. O problema já tem uma solução pré-definida que é dada pela figura na tampa da caixa do jogo. Quando um estudante se torna um "cientista normal", ele não contesta, nem sequer desconfia do conjunto de informações em vigor. As falhas na solução dos novos problemas são, dessa maneira, consideradas falhas do próprio cientista.

Kuhn identifica, olhando para a história, duas grandes fases na dinâmica das teorias científicas: a Ciência Normal (fase em que a maioria dos cientistas tenta resolver os novos problemas de maneira similar à resolução dos problemas exemplares do paradigma em vigor, reafirmando-o) e a Revolução Científica (fase em que, após um ou mais problemas insistirem em não serem resolvidos pelo paradigma, a ponto de serem considerados anomalias, surgirem novos candidatos a paradigma durante um período de crise). $\mathrm{O}$ paradigma em vigor não seria descartado até que outro candidato aparecesse, mostrando-se capaz de resolver os problemas que o paradigma anterior possuía dificuldades em resolver.

Verifiquemos que os cientistas não são fomentados a ser criativos. Eles são doutrinados no paradigma, e não para refutá-lo, mas para expandir ao máximo suas aplicações. Sempre tentando resolver os problemas já sabendo de antemão o resultado que esperam. Isso não seria encarado de forma ruim, pois permitiria o fortalecimento e a ampliação da coerência interna do paradigma por um tempo. Ainda assim, Kuhn não gosta de utilizar a palavra progresso. Isso porque, ainda que um paradigma progrida com o tempo, sua substituição é absoluta, e seus conceitos são descartados ou amplamente modificados após uma Revolução Científica.

Aceitando tais ideias, a relação entre o conhecimento científico e a verdade é muito mais humilde: a verdade passa a ser aquilo que a comunidade científica aceita como paradigma. Verdade vira sinônimo de consenso, e não de realidade. Ela ganha um adjetivo inseparável: verdade histórica, ou seja, contextualmente delimitada.

Como relacionar essas ideias com nossa pergunta guia? Questionemos o seguinte: as pessoas ficam anotando incontáveis relatos das mais diversas experiências para posteriormente utilizar a lógica indutiva e confirmar que a verdade absoluta é que este mundo é Real? Ou elas ficam formulando hipóteses ousadas sobre a realidade deste mundo para tentar refutá-las, aproximando-se, desta maneira, da verdade ao excluir as hipóteses 
descartadas? Ou a maioria das pessoas apenas aceita que este mundo é real e resolve seus problemas partindo deste pressuposto?

Para nós, a maioria das pessoas não concluiu por meio do método baconiano ou popperiano que este mundo é real, mas apenas incorporou esta ideia e foi seguindo com a vida. O mesmo parece acontecer no filme. Milhares e milhares de pessoas continuam presas à Matrix sem contestar o paradigma da realidade.

Mas, no caso do filme, as semelhanças com as ideias de Kuhn vão um pouco além. Basta nos perguntarmos: como foi que descobriram, pela primeira vez, que a Matrix não era o mundo real? De acordo com a trilogia, não foi por indução ou por falsificação de hipóteses. As pessoas possuíam um paradigma aceito de que o mundo em que viviam (a Matrix) era real. E isso era bom para as máquinas. Entretanto, após um tempo, surgiu um ser humano que se libertou. As máquinas denominaram esse problema de anomalia. Ainda no primeiro filme, o Agente Smith confessa que já existiu um outro paradigma de realidade. Ele diz que a primeira Matrix era perfeita. Tal versão é confirmada pelo Arquiteto no segundo filme. E, segundo este, o Neo em questão não é a primeira anomalia; na verdade, a irregularidade seria sistêmica, e sempre antecederia uma crise que seria resolvida selecionando alguns humanos para reiniciarem Zion, a última cidade humana.

Ou seja, assim como nas ideias de Kuhn, o período de transição entre um paradigma e outro não é aceito pacificamente. Por fim, segundo Kuhn, ocorre uma Revolução e outro paradigma passa definitivamente a ser aceito quando os defensores do antigo paradigma falecem, como afirma Planck numa frase muito conhecida (KUHN, 1975, p. 191) ${ }^{25}$.

Como vemos, a mesma estrutura suposta por Kuhn para a dinâmica da ciência ocorre em Matrix. Existe um paradigma, que é a crença na Realidade. Surgem algumas anomalias (na visão das máquinas), começa uma crise e ocorre uma revolução quando outro paradigma é aceito. No caso de Matrix, o novo paradigma ao final da Revolução do terceiro filme é: finalmente existe uma paz entre humanos e máquinas (e os humanos ainda conectados à Matrix apenas serão libertados se tomarem consciência de que a realidade não é tão real assim).

Resumindo, a estrutura das revoluções científicas relativiza o critério de demarcação entre o que é ciência e o que não é. Contudo, Kuhn não aborda sistematicamente a influência dialética entre ciência e contexto sócio-histórico, apesar de abrir a possibilidade dessa leitura.

\footnotetext{
${ }^{25}$ Quando Kuhn lançou seu livro, foi criticado por usar o termo paradigma de formas muito distintas. Aceitando a crítica, ele reformulou sua teoria, abrangendo o conjunto de ideias seguidas pela comunidade científica sob o termo Matriz Disciplinar. A revolução no paradigma, que segundo a nova terminologia poderíamos chamar de Revolução na Matriz, parece o título do último filme. Coincidência curiosa.
} 
O próximo filósofo que abordaremos não ignora tais pontos. Para adentrar em suas considerações, podemos iniciar com um questionamento importante: são compatíveis as ideias de "método científico único como guia de um trabalho científico objetivo" e de "ciência enquanto construção relacionada à época e ao contexto sócio-político-econômico-cultural’?

É preciso problematizar essa questão. Será que, ao olharmos para a história da ciência, constataremos que somente uma metodologia rígida e única foi utilizada sempre que se praticava a ciência?

Existem pensadores que afirmam que não. Somente de passagem, podemos citar Gaston Bachelard. Este considerava que "ao lado da evolução do conhecimento científico em si mesmo, havia uma evolução metodológica passando por várias escolas: animismo, realismo, positivismo, racionalismo, até chegar ao racionalismo completo e dialético, ao surracionalismo" (ZANETIC, 2006, p. 90). Para ele, a ciência se caracterizaria por momentos de continuidade e de ruptura, e a retificação dos erros, vistos como obstáculos epistemológicos, levaria ao progresso.

Portanto, ainda que seja possível encontrar na história exemplos em que os métodos popperiano ou baconiano foram usados para construir a ciência (e isso, por si só já derrubaria a ideia de que existe um só método), a pergunta que nos resta é: não utilizar um método científico único significa não desenvolver o conhecimento científico? E, mais do que isso, se não for utilizado algum método científico, isso significa que não podemos confiar no conhecimento científico desenvolvido? Enfim, o que diferencia um procedimento científico de um não-científico? Segundo

\section{II.2.6 - PAUl FeYerabend (1924 - 1994):}

...procedimentos "não-científicos" não podem ser postos de lado por argumentos. Dizer "o procedimento que você usou não é científico, portanto não podemos confiar em seus resultados nem dar-lhe dinheiro para pesquisa" pressupõe que a "ciência" seja bem-sucedida e é bem-sucedida porque usa procedimentos uniformes. A primeira parte da asserção ("a ciência é sempre bem-sucedida") não é verdadeira, caso por "ciência" queiramos nos referir a coisas feitas por cientistas - há também muitos fracassos. A segunda parte que os sucessos devem-se a procedimentos uniformes - não é verdadeira, porque não há tais procedimentos. Cientistas são como arquitetos que constroem edifícios de diferentes tamanhos e diferentes formas, que podem ser avaliados somente depois do evento, isto é, só depois de terem concluído sua estrutura. Talvez ela fique em pé, talvez desabe - ninguém sabe (FEYERABEND, 2007, pp. 20:1).

Mais do que isso, Feyerabend argumenta que as regras do racionalismo, que tenta defender a existência de um método científico, quando levadas às últimas consequências, 
acabam provando justamente o contrário: que se as regras fossem seguidas, não haveria progresso no conhecimento. Além disso, ele dá exemplos evidenciando que as supostas 'regras a serem seguidas por pesquisadores' não se sustentam após uma análise histórica, e afirma:

Está claro, então, que a idéia de um método fixo ou de uma teoria fixa da racionalidade baseia-se em uma concepção demasiado ingênua do homem e de suas circunstâncias sociais. Para os que examinam o risco material fornecido pela história e não têm a intenção de empobrecê-la a fim de agradar a seus baixos instintos, a seu anseio por segurança intelectual na forma de clareza, precisão, "objetividade" e "verdade", ficará claro que há apenas um princípio que pode ser defendido em todas as circunstâncias e em todos os estágios do desenvolvimento humano. É o princípio de que tudo vale (FEYERABEND, 2007, pp. 42:3).

Ou seja, não haver regras rígidas seria muito mais condizente com a ideia de progresso do que a imposição de regras demasiado fixas para responder às perguntas da mente humana ${ }^{26}$. Resumindo, a regra funcional ou o método para desenvolver o conhecimento, seja ele científico ou outro, segundo Feyerabend, é não haver método. Poderíamos interpretar isso como: há uma maior probabilidade de expandir o conhecimento diminuindo as restrições para tal expansão.

Ele vem, portanto, desmistificar a crença no Método Científico, retirando a neutralidade desse ramo do conhecimento, considerando-o influenciado e influente nas opiniões, crenças e formações culturais.

Qual a nossa resposta final para a pergunta chave: como saber se este mundo em que vivemos é Real? Tentando descobrir isso das mais diversas maneiras possíveis: seja utilizando a teologia, a ciência, a arte, etc. De fato, é isso que acontece quando observamos os episódios de Animatrix. As personagens descobrem que o mundo em que vivem é uma ilusão de diversas maneiras: em $O$ Recorde Mundial, um corredor descobre indo ao limite do seu corpo na prática do esporte; em Uma História de Detetive, um detetive descobre por meio de uma investigação para a qual fora contratado; e, em Era uma vez um garoto, o garoto descobre seguindo as dicas de Neo e Trinity.

\section{II.3 - POUT-POURRI HistóRICO}

Subtraindo as divagações sobre o filme, utilizemos essas reflexões epistemológicas para pensar criticamente a história da ciência e sua presença na educação, pois conclusões

\footnotetext{
${ }^{26}$ A ausência de uma regra lógica única para o desenvolvimento científico significa que a natureza não possui uma lógica? Ou a lógica encontrada na natureza é uma criação da mente humana?
} 
semelhantes podem ser referidas à ficção científica. Em vez de realizarmos uma incursão pessoal por tal assunto (como fizemos no caso da filosofia da ciência), seguiremos aqui as reflexões do próprio Zanetic. Podemos organizar seu diálogo com outros pesquisadores em algumas categorias dicotômicas.

a) História internalista $\leftrightarrow$ história externalista.

A primeira é uma forma de contar a história focando-se na dinâmica intrínseca dos conceitos, das hipóteses, dos aparatos que constituem as teorias. É uma leitura exclusivamente epistemológica da sucessão das ideias científicas, comparando-as, arrolando-as, associandoas.

Já a segunda consiste em uma concepção da história que não a desvencilha das influências extrínsecas, do contexto sócio-histórico-cultural. Isto é, ela narra a história tendo em vista possíveis relações entre a economia, a religião, a tecnologia, a educação, e as concepções dos cientistas em diferentes regiões espaço-temporais.

b) Recorrência histórica $\leftrightarrow$ reconstrução racional.

Ainda que não seja a regra, podemos identificar a reconstrução racional com uma visão mais internalista. Isso porque ela consiste em uma narração epistemológica da história, privilegiando as teorias, personalidades, experiências, etc., condizentes com a ciência contemporânea. É, portanto, uma distorção ad hoc que valoriza apenas a "seqüência de idéias, fenômenos, teorias, que tenham alguma contribuição a dar ao entendimento das teorias atualmente aceitas pela comunidade científica" (ZANETIC, 1989, p. 108). Seu objetivo é classificar, selecionar, omitir, interpretar e rearranjar cronologicamente eventos e fatos, "melhorando", reescrevendo, de forma anedótica e neutra, o encadeamento de diferentes cientistas, descartando o que parece irrelevante ou irracional tendo em vista o conhecimento moderno. Ela intenta, portanto, justificar, legitimar a concepção atual construindo uma "linha comprobatória" que busca antigos precursores (inseridos em epistemologias que não são suas) e vem mostrando a ciência como um empreendimento cumulativo e linear, fiel ao passado. Segundo Zanetic, essa leitura que vê a importância da história somente enquanto confirmação da ciência presente é defendida, por exemplo, pelo filósofo Imre Lakatos.

A recorrência histórica também se identifica com a tendência internalista; porém não intenta esconder as idiossincrasias pessoais, os valores, as filosofias, enfim, tudo que 
demonstra as vicissitudes do fazer e do quefazer científico. Em sua arqueologia, ela revê os antecessores dos paradigmas presentes, mas sem descontextualizá-los. Seu objetivo é justamente deixar os ziguezagues dessa intrincada teia evidente para, olhando-os criticamente, evitar recair nos mesmos obstáculos epistemológicos, elucidando teorias passadas e contemporâneas iluminando-as com a filosofia presente - como diria Bachelard. E, para Kuhn, a história pode "fornecer elementos que permitirão maior variedade de hipóteses para resolver as futuras crises" (ZANETIC, 1989, pp. 111:22).

Já Feyerabend defende a inclusão das influências socioculturais na narrativa histórica justamente para enriquecer a reflexão e repensar a práxis dialética com o presente. Com isso, sua visão não se restringe à epistemologia, o que lhe aproxima da história externalista.

c) Prós e contras do uso da história da ciência na educação.

O que fica evidente é que as reconstruções "racionais" (?!) são usualmente defendidas por motivações "pedagógicas" (?!). Ou seja, sua justificação parte de uma visão do cientista e de sua prática. Parte do pressuposto que o uso da história apresenta violentos perigos ao impressionável educando, uma vez que o contato com teorias descartadas pode ser perturbador, subversivo, ou ainda porque a percepção das vicissitudes de uma pesquisa pode desestimular, desanimar, desencorajar os estudantes. Por isso, os manuais didáticos reconstruídos apresentam uma história estática, estreita, rígida, inerte, morta. É por isso também que, segundo tal perspectiva, o estudante de ciência não necessita ler os textos dos grandes cientistas do passado.

A nosso ver, esse protecionismo confunde história com histeria, e parte de uma visão deturpada e muito pessimista do ser humano, legitimando uma distorção/invasão cultural ao manipular-lhe a reflexão e, portanto, a práxis. Mas, como ressalta Zanetic (1989, p. 112), essa reação à história da ciência encontra respaldo institucional (se considerarmos a política de publicação intensiva de artigos que pressiona os pesquisadores subtraindo-lhes o ócio criativo e o tempo de maturação e reflexão) e é inconsciente (na propagação invisível e sorrateira dessa ideologia ortodoxa).

Se quisermos neutralizar o dogmatismo e libertar, ao invés de doutrinar e dissimular, é premente o estudo crítico dos matizes da história, representando-a justamente de forma dinâmica, orgânica, vivaz, como narrativa que desafia e instiga o imaginário dos educandos. Tal concepção não parte de uma visão de cientista e de sua prática, mas de uma visão do ser humano e de sua vida. 
Por fim, vale revelar que Kuhn recebe críticas de Popper e Feyerabend, por exemplo, ao explicar a funcionalidade da ciência normal por meio dos manuais reconstruídos. Contudo, como o próprio Kuhn ressalta, descrever o como e o porquê a ciência se perpetua não significa defender essa visão de mundo, nem prescrevê-la como método aos futuros cientistas (ZANETIC, 1989, p. 121).

Certamente essa sistematização relâmpago dos diálogos apresentados por Zanetic é pobre. Deixamos de lado, por exemplo, a pseudo-história identificada por Martin Klein e a quase-história criticada por M. Whitaker. Mas cremos que esse lampejo foi suficiente para apresentar conceitos que nos serão preciosos posteriormente.

\section{II.4 - FÍSICA: INSTITUIÇÃO SOCIAL}

Concordamos com Zanetic quando ele afirma que a ciência não vem imediatamente à mente de quem inicia um diálogo sobre a cultura. Mais de uma vez presenciamos sua crítica bem humorada afirmando que, ao se falar de cultura, muitos citam um samba de Noel ou um tango de Gardel, mas poucos lembram do teorema de Godel ou das equações de Maxwell. Completaríamos que, no máximo, iremos nos lembrar de uma invenção de Graham Bell.

Se pensarmos nas políticas de incentivo à cultura, como a atual Lei Rouanet, a questão que fica é: alguém pensa em requisitar verba dessa lei para uma atividade de produção ou divulgação científica? ${ }^{27}$ Supomos que raramente, e a questão é: por quê?

Em resumo, diríamos que a causa é a visão mítica e intocável de ciência que acumulamos nos bancos escolares e consumimos nos slogans mercadológicos. Ela não é encarada como parte da bagagem cultural ainda que recebida em mitos culturais. Parece distante da vivência real, do cotidiano. Visão agravada por conta do ensino profissionalizante que vem ganhando espaço cada vez maior nas escolas; ensino que domestica e adestra futuros trabalhadores, repetidores mecânicos de técnicas, e não desenvolvedores de novos saberes, novas ciências (ZANETIC, 1989, pp. 146:8). Mas, “....afinal queremos formar projetistas ou operadores de máquinas?” (CANDOTTI, 2009, p. 15).

\footnotetext{
${ }^{27}$ Inclusive institucionalmente essa divisão ciências exatas $\leftrightarrow$ arte é realizada. "A Lei no. 8.313 de 1991, mais conhecida como Lei Rouanet, instituiu o Programa Nacional de Apoio à Cultura (PRONAC), que canaliza recursos para o desenvolvimento do setor cultural, com as finalidades de: estimular a produção, a distribuição e o acesso aos produtos culturais (CDs, DVDs, espetáculos musicais, teatrais, de dança, filmes e outras produções na área Audiovisual, exposições, livros nas áreas de Ciências Humanas, Artes, jornais, revistas, cursos e oficinas na área cultural, etc); proteger e conservar o patrimônio histórico e artístico; estimular a difusão da cultura brasileira e a diversidade regional e étnico-cultural, entre outras." Fonte: site do Ministério da Cultura <www.cultura.gov.br . Acesso em: 22/07/2010.
} 
Para problematizar essa questão e mostrar a física como um elemento cultural condicionante do mundo contemporâneo, Zanetic busca o nascimento da ciência enquanto instituição social, sua consolidação e reconhecimento. Pelos trabalhos de Robert K. Merton e Boris Hessen, dentre outros, ele dialoga sobre as peripécias e percalços do desenvolvimento dessa instituição a partir do século XVII, evidenciando que em muitos momentos a estrutura socioeconômica da época impactou a escolha de temas pesquisados pelos cientistas. Como uma via de mão dupla, as necessidades socioeconômicas influenciam e dependem da investigação científica. Inclusive, a ciência pode ser interpretada como um Aparelho Ideológico de Estado (ALTHUSSER, 1985).

Já as visões como as de G. Clark, H. Butterfield e A. Hall consideram que os cientistas não estão interessados pelas aplicações práticas de suas pesquisas. Conforme salienta Zanetic (1989, p. 155), tais visões parecem partir do pressuposto de que essa dependência feriria a autonomia e a objetividade da ciência, diminuindo sua validade.

Contudo, existem exemplos mostrando o contrário, mesmo porque o financiamento para a pesquisa advém do Estado, da indústria, etc. Presenciamos, certa vez, o professor Luis Carlos de Menezes argumentando nesse sentido, revelando uma sagacidade espirituosa ao falar que a existência dos "gênios" da ciência depende de um pozinho mágico (e dizia isso fingindo derrubar pó com a mão, entre os dedos indicador e polegar, sobre um mapa-múndi imaginário). Depois ele virava a mão mantendo o esfregar de dedos, e o que antes parecia um derrubar de pozinho mágico sobre países afortunados passava a parecer um gesto popular que significa dinheiro!

Newton realizava pesquisas de acordo com as preocupações econômicas iminentes de sua época, como o movimento dos projéteis lançados pela pólvora recém-chegada à Europa. Einstein pensava sobre a sincronização de relógios em sintonia com os problemas dos telégrafos, novidades do começo do século XX. Na mesma época, Planck tentava compreender gráficos de temperatura dos fornos siderúrgicos, uma vez que a qualidade do aço depende precisamente da temperatura de sua produção, etc., etc.

Possivelmente por ser tão facilmente aparente, o impacto da ciência sobre a estrutura social, especialmente por intermédio dos seus subprodutos tecnológicos, tem sido durante muito tempo objeto de interesse, senão de estudo sistemático. É fácil constatar que a ciência é uma força dinâmica de mudança social, embora nem sempre de mudanças previstas ou desejadas. De vez em quando até os físicos saíram dos seus laboratórios para reconhecer, com orgulho e surpresa, ou para repudiar, com horror e vergonha, as consequiências sociais de seu trabalho. A explosão da primeira bomba atômica sobre Hiroshima nada mais fez que comprovar o que todo 
mundo sabia. A ciência tem conseqüências sociais (MERTON apud ZANETIC, 1989, p. 156).

Essa via da avenida parece ser consenso. A volta é que parece mais polêmica, e nem todos aceitam as influências do contexto sobre a investigação científica. Talvez por isso Zanetic busque exemplificar a ligação entre a ciência e a cultura, com especial enfoque à relação entre a física e a arte (literatura, música, teatro...). Em seus trabalhos publicados desde sua tese ele se inspira em autores que evidenciam possíveis influências de Dostoievski sobre Einstein e deste sobre sambistas. Sempre nos dois sentidos, considerando, finalmente, a seguinte classificação (ZANETIC, 2005): cientistas com veia literária (H. G. Wells; J. Kepler) e escritores com veia científica (E. A. Poe; J. L. Borges).

\section{II.5 - CiÊNCIA: Mitologia OPRESSORA OU CONHECIMENTO EMANCIPADOR?}

Por conta dos mitos em torno do método científico, que denominaremos daqui em diante de mito positivista ingênuo - ingênuo porque sequer se aproxima da profundidade e extensão do positivismo de Auguste Comte (1988) -, propaga-se uma visão de ciência cumulativa, objetiva e linear. Visão que possui sérias consequências sociais. Em primeiro lugar, ao difundir que a ciência é neutra, ela parece a-histórica. Sendo a-histórica, ela desumaniza-se. Desumanizada, ela torna-se berço de hierarquias totalitárias e, consequentemente, de opressões. Em vez de se tornar um caminho para se deliciar com o cosmos, ela torna-se instrumento de dominação daqueles que se acham mais sobre aqueles que se acham menos.

Não se amam mais as cores 173).

mas sim as hierarquias (MAIAKÓVSKI, 2008, p.

Que pena! Justamente na "era da racionalidade", em que se vangloria pela profundidade do conhecimento, relega-se a nós, homens e mulheres, uma posição fundada em lendas e longe da esfera das escolhas conscientes, críticas, pois afundamo-nos no mito de que a ciência é um conjunto de dados dado, inquestionável.

Que há apenas um método científico, é um mito. Existem vários, e todos delimitados historicamente. Isto é, não negamos que, para empreender um estudo científico, o metodismo e as dúvidas sistemáticas são fundamentais. Mas é por isso mesmo que tais métodos não podem ser propagados como mitos opressores, mas devem ser discutidos como possível 
postura emancipadora. Eles possuem limites, e são nessas fronteiras que se revelam aspectos importantes das escolhas conscientes.

Em suma, como vimos, Zanetic coloca diversos autores para dialogarem entre si e, é claro, toma parte na contenda. No debate entre o ensino tradicional e a proposta freiriana, entre a história internalista e a externalista, entre as epistemologias prescritivas, as descritivas e as anárquicas, etc., descortinam-se admiráveis mundos novos.

Se a práxis se caracteriza dialeticamente pela reflexão e pela ação, após adentrar nessas interlocuções, parece-nos imprescindível a uma prática pedagógica consciente a ponderação sobre as questões acima. Pretende-se, com isso, abolir a distância, a dicotomia, a antinomia entre a cultura científica e a cultura escolar para permitir, finalmente, uma aproximação entre a cultura vivencial diária e uma nova cultura científica escolar.

...a física ensinada em nossas escolas é essencialmente matemáticooperacional, metodologicamente pobre, sem experimentos, sem história interna ou externa e desligada da vivência dos alunos e da prática dos cientistas. Por tudo isso, a física ensinada nas escolas, a física escolar, nasce sob o signo do distanciamento com relação à "física real".

Será que essa distorção ocorre por razões "didáticas"? É possível, sem dúvida devido a "más didáticas". Por exemplo, a ênfase em se ensinar algo que seja possível "devolver" depois num exame, seguindo o lema comportamentalista de "não ensinar aquilo que não possa ser avaliado". Isso provoca a trivialização do conhecimento a ser ensinado (ZANETIC, 1989, p. 177).

Tendo em vista todas as visões suscitadas, continuaremos nossa dissertação com a premissa de que a física é cultura, e que só compreendendo-a como cultura, antropológica, condicionada e condicionante de uma unidade epocal, como leitura válida de mundo e como transformadora da realidade, sua aprendizagem se mostrará rica e desafiadora para os educandos, libertando-os dos mitos que fazem da ciência mais um instrumento de opressão em uma sociedade contaminada pela aceitação de maldosas hierarquias desumanizantes.

Essa premissa está, aos poucos, ganhando terreno, já (finalmente) se projetando nos Parâmetros Curriculares Nacionais (MENEZES, 2009) e nos livros metodológicos de formação de professores (DELIZOICOV et al., 2007).

Partindo dessa concepção, tanto os conceitos científicos podem ser encarados como abstrações a serem desmistificadas, como a própria prática científica, em suas relações com a economia, a política, a ética..., também pode ser objeto de uma pedagogia problematizadora. 
Uma amostra:

Pólos sul e norte...

Meu tédio gageiro,

Por que estranha sorte

Não há um terceiro?

Mas a terra... a ciência,

Ciência, sim, isso já...

Já disse... Evidência...

Mas porque o não há?

Esse poema de F. Pessoa (2006, p. 220) poderia ser um tema gerador. Ele é sucinto, e revela a percepção de que o uso dos termos pólo norte e sul não explica por si só o feitiço do magnetismo, pois os rótulos empregados podem ser tão místicos quanto a própria magia. A percepção do mito é o primeiro passo para a aprendizagem, porém não a garante solitariamente. O segundo passo consiste justamente na desmistificação daquilo que se apresenta mágico. Caberia aqui problematizar o que é uma evidência científica, como ela contribui para o estabelecimento de uma teoria, como a teoria é elevada ao status de verdade, etc., etc. Gostaríamos de encerrar este capítulo, portanto, com a esperança de que 'os ventos da mudança' se aproximam.

Qualquer que seja a alternativa, o ensino de física dificilmente prosseguirá da mesma forma que tem sido conduzido, pois há um limite para a postergação artificial de anacronismos. Tendo em vista a dificuldade que temos tido para promover a reforma, é duvidoso afirmar que promover um ensino de física renovado seria mais fácil do que administrar sua fusão em um ensino de ciências mais abrangente e significativo. Aliás, eu nem sequer tenho um palpite claro sobre o que predominará nas próximas décadas, mas é certo que como está não fica. Quem viver verá (MENEZES, 2009, p. 45). 


\title{
CAPítulo III
}

\author{
Realidade, Pensamento e Linguagem
}

OU

'VIAGEM FANTÁSTICA II: RUMO AO CÉREBRo'

O peão é a peça mais importante do jogo de xadrez... do ponto de vista do peão.

Isaac Asimov, 1987, p. 50.

No dia a dia, imenso jogo de xadrez em suas infinitas escolhas, cada pessoa aprende e segue algumas regras. Regras que, na visão de Freire, não deveriam negar o eu, mas afirmar o nós, em uma competição cujos adversários são a acomodação, a injustiça e a descrença. Portanto, regras dialógicas, e não leis intransponíveis. Que devem ser elaboradas com os peões, e não para os peões - com o intuito de, dialeticamente, possibilitar e balizar as atuações na grande partida da vida.

A questão que trataremos neste capítulo é: entrando no meio do fluxo do jogo do mundo, estando certo regulamento já em vigência, como um ser humano aprende a lidar com suas regras?

Para procurar respondê-la, realizaremos um passeio por alguns ramos da filosofia da linguagem e uma viagem fantástica rumo ao cérebro, na tentativa de embasar minimamente na psicologia algumas hipóteses sobre a aprendizagem e a relação entre o pensamento e a linguagem. 
O ensino de ciências pressupõe a existência de uma relação entre a linguagem científica e a realidade. No capítulo anterior, vimos alguns elementos que permitem um olhar mais crítico sobre essa relação, atentando para ingredientes filosóficos, históricos e sociológicos. Falta ainda discutir a relação entre a linguagem e a aprendizagem.

Porém, antes de buscar entender como um ser humano aprende a linguagem (ou seja, como o novo compreende o velho; como o indivíduo incorpora leituras de mundo já presentes no sistema para usufruí-las e/ou subvertê-las), convém buscar algumas visões mais específicas sobre a relação entre a linguagem, o pensamento e a realidade. Isso para refinar nossa percepção das relações homens-homens e homens-mundo. Para tanto, vamos comparar as ideias de dois pensadores que, segundo diferentes perspectivas, analisaram a linguagem.

\section{III.1 - LUDWIG WiTTGENSTEIN: 'O HOMEM COM DOIS CÉREBRos’}

Wittgenstein (1889-1951) foi um filósofo austríaco curioso sobre a relação entre a linguagem e o mundo. Podemos dividir sua obra em dois momentos distintos, com conclusões bem diferentes.

No primeiro Wittgenstein, referente ao livro Tractatus Logico-philosophicus, existe uma preocupação de garantir a univocidade, o paralelismo entre a lógica da linguagem e a lógica do mundo, pois, para ele, a estrutura da linguagem seria uma consequência e uma evidência da estrutura do universo real que ela representa. Ou seja, uma sentença seria uma figuração direta da própria realidade - haveria uma vinculação denotativa imediata, uma conexão associativa, já que a lógica interna da primeira decorre da lógica da segunda. Logo, para compreender e explicar o mundo, analisam-se as proposições. Elas possuem um significado verdadeiro, genuíno, um sentido elementar passível de ser evidenciado. Com base nisso, as questões filosóficas são questões da linguagem. O propósito da filosofia seria justamente descrever o que há de comum à linguagem, à realidade e ao pensamento.

Isso não é um nominalismo, pois as palavras não são vistas como "etiquetas" de objetos reais. Para Wittgenstein, o significado das proposições antecede o dos nomes (JANIK; TOULMIN, 1991, p. 215), e a relação vigente entre a lógica da realidade e a da linguagem se dá por meio das proposições. São estas que representam os fatos.

Já as proposições sem ligação com os fatos reais são as tautologias e as contradições. A rigor, para Wittgenstein, elas não são proposições, pois são vazias de sentido. Elas não exprimem nenhuma realidade e nem possuem condições de verdade. As primeiras são 
incondicionalmente verdadeiras e permitem todas as situações possíveis; as segundas são incondicionalmente falsas e não permitem nenhuma situação (D’OLIVEIRA, 1999, p. 11).

A linguagem afigura, manifesta a realidade, e é isso que garante a compreensibilidade do pensamento. Podemos dizer que existe uma relação de subordinação nessas relações. A lógica do mundo permite a lógica da linguagem que permite o pensamento.

E mais, para esse primeiro Wittgenstein, “as proposições genuínas dizem apenas o que as coisas são, não como elas devem ser" (D’OLIVEIRA, 1999, p. 12). Isto é, elas são descritivas, não prescritivas. O que torna logicamente impossível inferir de uma descrição de um estado de coisas a decorrência da existência de um outro estado de coisas (esta é uma outra forma de concluir aquilo que Hume afirma). Que o Sol nascerá amanhã é uma hipótese, não uma certeza. Seguindo tal raciocínio, uma sequência de eventos é uma obra do acaso. E, se os acontecimentos são acidentais, separam-se os atos de vontade e a realização do desejado.

Não posso subjugar os acontecimentos do mundo à minha vontade: sou completamente impotente (WITTGENSTEIN apud D'OLIVEIRA, 1999, p. 12).

Aliás, se tanto uma proposição quanto sua negação são possíveis, a proposição verdadeira também é acidental, fortuita. Por exemplo, tanto o bem quanto o mal são aleatoriamente possíveis. De onde ele conclui que não existem proposições em ética, ou seja: os valores não estão no mundo. A ética é transcendental, assim como o homem.

O sujeito não pertence ao mundo, mas é limite do mundo (WITTGENSTEIN apud D'OLIVEIRA, 1999, p. 13).

O que não quer dizer que os tópicos metafísicos são absurdos, mas apenas que eles se situam além do alcance da linguagem, e que "existe com certeza o indizível" (WITTGENSTEIN apud D'OLIVEIRA, 1999, p. 13). Com isso ele demarca o limite de validade da linguagem (e, de acordo com sua lógica, da verdade) científica, completando um caminho iniciado pelo filósofo Immanuel Kant (1724-1804). Daí ele afirmar que "o que não se pode falar, deve-se calar" (idem, p. 9), pois a verdade metafísica só pode ser indicada, apontada (e não falada) por meio da arte. A poesia, por exemplo, pode mostrar o sentido da vida porque não consiste de proposições, e não pode ser descrita em termos fatuais (JANIK; TOULMIN, 1991, p. 225).

Já o segundo Wittgenstein, referente às Investigações Filosóficas, contesta esse primeiro, pois não mais acredita que exista esse isomorfismo, essa estrutura lógica por trás da linguagem, essa essência única e singular que garantiria um espelhamento com o mundo. Ele 
evita inclusive usar a palavra lógica, tentando escapar dos preconceitos que ela suscita, passando a utilizar a palavra gramática, dentre outras, em vez disso.

Agora, a linguagem é viva, plural e supersticiosa, pois traz em si os hábitos de seu uso. A função da filosofia é iluminar, neutralizar os feitiços da linguagem sobre o pensamento. Ou seja, não se deve almejar descobrir algo supostamente escondido, sorrateiro, por detrás da linguagem, mas tentar entender como ela funciona, para descartar os falsos problemas que permanecem, por exemplo, por força de tradição.

O significado da linguagem é dado por aquilo que nos está à mostra, isto é, pelo uso dos enunciados e proposições. Com isso, ele mudou o foco da 'compreensão metafísica da estrutura lógica' para a 'descrição prática do uso e da finalidade de cada proposição'. Correndo o risco de falsear suas ideias, poderíamos dizer que ele mudou da busca pela essência para a descrição da aparência. A bem da verdade, mais correto seria afirmar que ele defende que a essência é a própria gramática, com o serviço que ela nos presta ao nos mostrar os padrões para o uso correto (e não verdadeiro ou bom... não é uma valoração) da linguagem.

Não faz sentido perguntar qual o significado de uma palavra. Isso é um mito, pois o significado não emana dela, ela não é portadora dele. O que faz sentido é o que é empregado corretamente. A palavra é um ato. A linguagem é uma atividade. Ação que suscita uma reação compreensível ou equivocada. Ter o mesmo significado é produzir o mesmo efeito. $\mathrm{O}$ significado varia de acordo com o contexto e o pretexto. Compreender o significado de uma proposição é interpretar o propósito de quem a enuncia em determinada ocasião. Interpretação que depende da frequência de sua ocorrência, da probabilidade de seu uso em determinado ambiente, etc. Não se compreende a linguagem fechando-se sobre ela mesma devido a sua dependência, a sua falta de autonomia em relação às práticas e aos comportamentos humanos (RUY, 2008, p. 11).

Logo, compreender uma linguagem é descrever seu funcionamento, é dominar uma técnica. Compreender uma palavra é descrever seu uso. E esse uso é variado, múltiplo. Uma palavra tem várias funções práticas. Cada vez que nos deparamos com um novo uso de uma palavra, aprendemos uma nova função. A própria compreensão ganha um status dinâmico, vivo. Para esse segundo Wittgenstein existe uma mudança de postura frente à significação e à compreensão: ambas devem ser encaradas organicamente, mutáveis, influenciáveis pelo uso em cada situação. A compreensão é um estado, e "é preciso primeiramente aprender a compreender" (WITTGENSTEIN, 1999, p. 48).

Para organizar tais reflexões, Wittgenstein supõe a existência de jogos de linguagem, empregados para afirmar, mentir, recusar, questionar, (fazer ciência, narrar ficção 
científica...), etc. Eles são um conjunto de práticas linguísticas. Não mais existe uma única linguagem ideal para espelhar o mundo, mas um conjunto de jogos de linguagem. As palavras não denotam, denominam e etiquetam símbolos fixos, signos indestrutíveis, designando objetos da realidade. Elas não remetem a imagens mentais privadas, perfeitas e incorruptíveis. A realidade, a linguagem e a memória são falíveis, inconstantes, e é a prática diária, cotidiana, interpessoal e dialógica que permite a compreensão da eficácia ou ineficácia das palavras, das formas verbais deliberadamente construídas. Importa, portanto, aprender o contexto e o objetivo do uso em cada caso, em cada ambiente adequado. A finalidade é legitimada pelo/ legitima o contexto.

Os diferentes jogos permitidos possuem uma norma, ainda que não seja uma mesma norma para todos. Eles seguem regras gramaticais distintas e mutantes, que se entrecruzam, se permutam, se embaralham. Percebemos panoramicamente que existe um parentesco entre os jogos, o que é descrito como uma semelhança, um ar de família, nada mais. Tal semelhança é de definição difusa, ainda que de alguma forma perceptível. É o costume de seguir regras que permite, pela descrição, pelo mapeamento desse somatório legal, a compreensão dos jogos de linguagem.

Não podemos adivinhar como uma palavra funciona. Temos de ver seu emprego e aprender com isso (WITTGENSTEIN, 1999, p. 114).

No primeiro Wittgenstein, as proposições significativas eram aquelas em conformidade com as regras da linguagem e, consequentemente, do mundo. Agora, sendo as regras maleáveis, tal "determinismo" é impraticável. Imersa em outras práticas humanas, nas danças da cultura e das visões de mundo, a linguagem é volúvel, versátil.

Por isso, o acesso ao uso é necessário para se apropriar a linguagem (dominar seus jogos). Concepção que tem implicações pedagógicas importantes, pois aprender não é só memorizar nomes, arquivar denominações estanques de objetos estáticos que vêm à mente, que eclodem perante o espírito quando requisitadas. Esse ensino ostensivo das palavras supõe que o aprendiz já sabe pensar, e apenas não pode falar! (WITTGENSTEIN, 1999, p. 39). Mas, vale afirmar, tal ensino ostensivo caracteriza-se por determinados jogos de linguagem legítimos em um contexto e seu propósito (supomos que eles já foram desvelados quando falamos da educação bancária).

Wittgenstein diferencia ainda o pensar (estado ou processo mental metafísico) do querer dizer. A intenção só faz sentido nos jogos do diálogo. O processo mental não é necessário nem suficiente para querer dizer algo, ainda que tal fenômeno e tal atitude possam se relacionar. Nesse caso, 
A questão porém é: como podemos julgar se alguém queria dizer isso? - É um critério, por exemplo, o fato de dominar ele uma determinada técnica da aritmética e da álgebra, e de dar a outro uma lição habitual sobre o desenvolvimento de uma série (WITTGENSTEIN, 1999, p. 163).

Em outras palavras: é complicado tentar inferir o pensamento de outrem, mas é possível criar critérios para determinar se o que tal pessoa quis dizer foi usado corretamente em comparação com a norma socialmente aceita. Vale deixar claro, isso não significa negar a mente, o espírito, a psicologia. Tampouco é um behaviorismo disfarçado (WITTGENSTEIN, 1999, p. 109). É a busca de uma conduta, de uma filosofia que identifique equívocos gramaticais, que libere as palavras da confusa bruma dos encontros entre regras de diferentes jogos de linguagem.

Em resumo, a mensagem central desse segundo Wittgenstein é (1999, p. 129):

Todo signo sozinho parece morto. $O$ que lhe dá vida? - No uso, ele vive. Tem então a viva respiração em si? - Ou o uso é sua respiração?

Em vez daquela subordinação unívoca entre realidade, linguagem e pensamento, característica do primeiro Wittgenstein, o segundo preocupa-se com o contexto e as inclinações do uso em dado momento, a perspectiva de mundo de quem dialoga. Um aspecto da realidade é contexto para determinados jogos de linguagem que são veículos para os propósitos de quem quer dizer algo. Aquela subordinação é substituída por uma intersecção entre particularidades dos inconstantes conceitos em questão. Uma relação dentre inúmeras, que só é válida quando justificada por um contexto e por uma necessidade. Isto é, aquela subordinação tractatiana é legítima, mas muito mais abreviada, mais peculiar, mais específica que a pluralidade dessas inúmeras relações idiossincráticas possíveis.

É possível generalizar, encontrar a essência, criar uma definição unificadora, precisa, exata, definitiva, de linguagem, realidade, jogos de linguagem, etc.? Não, pois tudo é plural e mutável. Qualquer idealização seria uma restrição distorcida. Isso é um problema? Não, é a percepção filosófica de um labirinto insolúvel, de um falso empecilho causado por modismos do pensamento, por paradigmas, por costumes, por instituições, por tentações psicológicas..., quimera que deve ser descartada, ilusão gramatical que deve ser recusada sem receios.

Em suma, aprender a linguagem é compreender como ela é empregada. Porém, Wittgenstein não aprofunda a questão do por que usar determinado jogo de linguagem. Parece-nos que seu objetivo é afirmar que a filosofia deve limpar o pensamento daquilo que se garante apenas pela tradição, dizendo como fazer isso, mas esquivando-se de verificar o outro sentido da avenida: a influência da linguagem na realidade. Parece mais pragmatismo que práxis. Intuímos um resquício daquela sensação de impotência do primeiro Wittgenstein. 
Talvez essa crítica assemelhe-se àquela recebida por Kuhn, acusado de aceitar o dogmatismo ao descrever o modo de funcionamento doutrinador da ciência normal. Mas descrever como algo funciona não significa concordar com esse modo de funcionamento. Descrição é diferente de prescrição. Afinal, se Kuhn e Wittgenstein nos auxiliam na reflexão, subsidiam, também, a ação, possibilitando que a práxis se complete. Para problematizar isso, abordemos outro filósofo da linguagem.

\section{III.2 - MikHail BAKHTIN: A DialétiCa Materialista SocioideológiCa}

Bakhtin (1895-1975) foi um filósofo/linguista/sociólogo russo interessado na relação entre a linguagem e a sociedade. Seu pressuposto axial: existem dois universos, duas realidades. O material (dos fenômenos naturais e dos artigos tecnológicos e de consumo) e o dos signos (que coincide com o universo ideológico). Essa diferenciação não quer dizer que o signo é imaterial, mas que objetos materiais não são, necessariamente, signos ideológicos.

Um corpo físico, instrumento de produção ou objeto de consumo, não é ideológico. Converte-se, torna-se ideológico quando sua função é a de um símbolo que extrapole suas particularidades, representando outra realidade - como o martelo e a foice no emblema da União Soviética. Já a língua é instrumento da criação ideológica (ato material e social), cujos produtos artístico-simbólicos fazem parte de uma realidade (natural ou social), refletindo e refratando uma outra realidade que lhe é exterior. Em suma, "tudo que é ideológico é um signo" (BAKHTIN, 2006, p. 31).

Todo fenômeno que funciona como signo ideológico tem uma encarnação material, uma realidade objetiva passível de ser estudada. O próprio signo e todos os seus efeitos (ações, reações, novos signos desencadeados...) aparecem na experiência exterior e coletiva. No domínio dos signos, cada campo de criatividade ideológica (ciência, religião, literatura, imprensa...) tem seu próprio modo de orientação e sua função particular no conjunto da vida social. A palavra, portanto, é neutra. O signo não. Este depende de sua função ideológica e, de acordo com Bakhtin (2006, p. 32):

...está sujeito aos critérios de avaliação ideológica (isto é, se é verdadeiro, falso, correto, justificado, bom, etc.).

Ao contrário do que afirmava o segundo Wittgenstein, não existe apenas um critério linguístico (está certo ou errado). O julgamento é valorativo, apreciativo, e não se reduz à adequação a alguma norma previamente estabelecida. E isso não se restringe aos diálogos, 
mas estende-se aos (supostos) monólogos, pois estes também possuem um auditório social próprio bem definido:

Toda enunciação monológica, inclusive uma inscrição num monumento, constitui um elemento inalienável da comunicação verbal. Toda enunciação, mesmo na forma imobilizada da escrita, é uma resposta a alguma coisa e é construída como tal. Não passa de um elo da cadeia dos atos da fala. Toda inscrição prolonga aquelas que a precederam, trava uma polêmica entre elas, conta com as reações ativas da compreensão, antecipa-as. Cada inscrição constitui uma parte inalienável da ciência ou da literatura ou da vida política. Uma inscrição, como toda enunciação monológica, é produzida para ser compreendida, é orientada para uma leitura no contexto da vida científica ou da realidade literária do momento, isto é, no contexto do processo ideológico do qual ela é parte integrante (BAKHTIN, 2006, p. 101).

Um texto de ciência ou de ficção científica, portanto, possui um pretexto e uma ideologia. Aspectos que devem ser pensados durante uma atividade pedagógica.

Nessa leitura de mundo, a consciência, a compreensão e a significação ganham um sentido distinto daquele que era usual na época de Bakhtin. Caracterizam-se no universo social, e não no individual. Universo que é real, e não abstrato. Realidade que é dinâmica, e não inerte; relacionada às condições de comunicação ligadas às estruturas sociais. Portanto, perpassada de ideologias. Em outras palavras, a pergunta que fica é: se a realidade e a linguagem são direcionadas por ideologias, como conceber nossa formação mental no seio social?

A psicologia cognitiva não pode ser reduzida às particularidades do psiquismo subjetivo ou situada na atividade mental individual, introspectiva, entendendo, com isso, fenômenos ou manifestações transcendentais, inacessíveis e inexploráveis. O organismo e o mundo se encontram no signo (BAKHTIN, 2006, p. 50). O indivíduo e o sistema se chocam no universo ideológico. Na confluência das realidades interior e exterior, a linguagem é produto/produtora da mente. E, sendo a linguagem material, ideológica e social, a consciência não poderia ser encarada de forma diferente. Nesse caso, a ideologia não é um fato interior que recebe um revestimento exterior da palavra. A compreensão se dá justamente através do material semiótico (portanto, ideológico), e a consciência se afirma na realidade, mediante a encarnação objetiva em signos.

Bakhtin critica também aquilo que ele chama de objetivismo abstrato: as análises que acertadamente consideram a língua como um fato social, porém afastando-a da realidade, imaginando-a como um ente abstrato, ideal, estático, homogêneo e equilibrado, distante das vicissitudes da fala cotidiana (YAGUELLO, 2006, pp. 14:5). Para ele, é justamente na aproximação entre a língua e a fala, na intercomunicação popular contextualizada no horizonte social, que a consciência, a língua e a significação se materializam e evoluem. Ele 
opõe-se ainda ao mecanicismo materialista pré-dialético (com sua causalidade inerte, unilateral, genérica e ingênua) e ao positivismo psicologista empirista (que abomina a teorização e supõe o fato intangível e imutável; e que reduz a criação artística, etc., a reações orgânicas psicofisiológicas, behavioristas).

A ideologia, para Bakhtin (2006, p. 35), não se explica em um nível supra-humano (no psiquismo metafísico, inexprimível, insondável), nem em um nível infra-humano (no atoreflexo biológico), mas justamente nas interações humanas, no material semiótico criado nesse/criador desse intercâmbio, manifestado nessa dialética, nessa troca sociológica evidente, cambiante, aparente, concreta.

Compreender um signo consiste em aproximar o signo apreendido de outros já conhecidos (BAKHTIN, 2006, p. 34). A relação entre a consciência e os signos é dialética, amparada na realidade material e interindividual, na necessidade de comunicação em uma sociedade organizada, repleta de ideologias. Os signos são o instrumento e o alimento do discurso interior. A ideologia, a consciência individual e os signos impregnam-se mutuamente em um "estoque social de signos disponíveis" (idem, 117). A mente está repleta deles, está imersa em conteúdo ideológico por conta da interação dialógica, e "a consciência não poderia se desenvolver se não dispusesse de um material flexível, veiculável pelo corpo" (idem, p. 37). A ideologia não deriva do discurso interior, pelo contrário. "A intersubjetividade é anterior à subjetividade" (BARROS, 1996, p. 28). A consciência individual não é transcendental. Nem é independente dos signos. Ela reflete a lógica semiótica (ideológica) e suas leis: as da comunicação social. Tais leis, por sua vez, são determinadas pela estrutura socioeconômica, que é histórica.

Portanto, quando Cazuza cantava “ideologia, eu quero uma pra viver", ele poderia querer outra, porque certamente uma ele já possuía - fosse consciente dela ou não, gostasse dela ou não. A bem da verdade, a letra aparentemente fatalista reverte-se em esperança quando ele canta com indignação, incitando o movimento.

O que nos mostra que a ideologia do signo é cultural. É influenciada pela $e$ influencia as transformações sociais. Não se reduz a seu valor denotativo racional (exemplo: o empobrecimento de uma classe social causa o surgimento de uma personagem decadente em um romance - tal reducionismo, ainda que justo, é muito pobre) nem à mera prática (exemplo: uma técnica arquitetônica desvinculada da ideologia). Desmembrá-lo é assassiná-lo. Ele é um todo único, orgânico, e deve ser compreendido na relação recíproca entre a infraestrutura (a realidade em suas relações econômicas) e as superestruturas (ideologias políticas, religiosas, jurídicas, científicas...). 
A palavra, mais especificamente, é indubitavelmente importante tendo em vista sua onipresença social. Ela sempre será um indicador de todas as instabilidades, flutuações e transformações da existência social - desde as mais sutis e efêmeras até as mais revolucionárias. Os conflitos na linguagem refletem, corporificam o confronto de classes ${ }^{28}$.

Classe social e comunidade semiótica não se confundem. Pelo segundo termo entendemos a comunidade que utiliza um único e mesmo código ideológico de comunicação. Assim, classes sociais diferentes servem-se de uma só e mesma língua. Conseqüentemente, em todo signo ideológico confrontam-se índices de valor contraditórios. O signo se torna a arena onde se desenvolve a luta de classes. Esta plurivalência social do signo ideológico é um traço da maior importância. Na verdade, é este entrecruzamento dos índices de valor que torna o signo vivo e móvel, capaz de evoluir.

$[\ldots]$

Mas aquilo mesmo que torna o signo ideológico vivo e dinâmico faz dele um instrumento de refração e de deformação do ser. A classe dominante tende a conferir ao signo ideológico um caráter intangível e acima das diferenças de classe, a fim de abafar ou de ocultar a luta dos índices sociais de valor que aí se trava, a fim de tornar o signo monovalente (BAKHTIN, 2006, pp. 47:8).

A tentativa da classe dominante de matar a dialética inerente ao signo, de petrificá-lo, de mutilá-lo, de prendê-lo ao dicionário e, consequentemente, de sabotar o pensamento da classe dominada é representada de forma brilhante na novilíngua do livro 1984 de George Orwell. Nessa distopia, a língua é usada em todo o seu potencial coercitivo por meio de suas normas. Ela é solapada, fragmentada, reduzida a mito intocável, a sloganização alienante, cujo intuito é justamente garantir a existência da sociedade opressora - com a desculpa de que esta garante a felicidade do povo. Mas, como nos ensina a música d’O Rappa (1999): “paz sem voz não é paz, é medo!”.

Afinal, a compreensão não é um ato passivo, mas uma resposta dialógica à pressão existencial, uma réplica ativa à tensão social: rejeita-a, apoia-a, reage, confirma, protesta... Distante, portanto, do fatalismo, da submissão, da resignação na adversidade (BAKHTIN, 2006, pp. 102:20). Por conta disso, é importante entender:

...como a realidade (a infra-estrutura) determina o signo, como o signo reflete e refrata a realidade em transformação (BAKHTIN, 2006, p. 42).

Isso possibilita uma psicologia do corpo social, uma ideologia do cotidiano, situada no exterior, nos atos, nas trocas, na superfície, inclusive no material verbal. Na fala corriqueira, nas mais diversas situações e ambientes, por meio de seus diferentes modos de discurso, concretiza-se a criação ideológica ininterrupta do dia a dia nas enunciações. Essas

\footnotetext{
${ }^{28}$ É importante frisar que Bakhtin não considerava a ideologia apenas como um espaço de ocultamento, como K. Marx, mas a via principalmente como espaço de contradição (FREITAS, 2002, p. 127).
} 
enunciações, na pluralidade dos diálogos (interior ou exterior, impresso ou falado...), não seguem apenas regras gramaticais, léxicas ou fonéticas (os três centros organizadores da pedagogia linguística), mas sucedem:

...segundo leis de convergência apreciativa (emocional), de concatenação de diálogos, etc... e numa estreita dependência das condições históricas da situação social e de todo o curso pragmático da existência (BAKHTIN, 2006, p. 65).

De um modo geral, tais leis de concatenação, etc., permitem entrever uma impressão global das enunciações (um "ar de família", como diria Wittgenstein).

Que fique claro: a palavra é polissêmica, versátil, plurivalente, viva.

O sentido da palavra é totalmente determinado por seu contexto. De fato, há tantas significações possíveis quantos contextos possíveis. No entanto, nem por isso a palavra deixa de ser una. Ela não se desagrega em tantas palavras quantos forem os contextos nos quais ela pode se inserir. Evidentemente, essa unicidade da palavra não é somente assegurada pela unicidade de sua composição fonética; há também uma unicidade inerente a todas as suas significações. Como conciliar a polissemia da palavra com sua unicidade? É assim que podemos formular, de modo grosseiro e elementar, o problema fundamental da semântica (BAKHTIN, 2006, pp. 109:10).

Certamente a solução não é descontextualizar a palavra, cristalizando-a em definições mortas. Aliás, esses contextos são plurais, sequer estão em um mesmo plano. Vide as confusões geradas pelos diálogos em que cada locutor enuncia a palavra tendo como vivência de sua significação contextos distintos. É justamente nesse conflito dialógico, nessa tensão ininterrupta, que reside a vivacidade da palavra: "as unidades reais da cadeia verbal são as enunciações” (BAKHTIN, 2006, p. 129; grifo nosso).

Essas enunciações ideológicas se manifestam no embate entre dois pólos: a atividade mental do eu e a atividade mental do nós. Esta não deve (ou não deveria...) ser considerada como uma atividade primitiva ou gregária, mas como uma atividade diferenciada, coletivamente bem organizada, que permite a conscientização e a distinção individual. O que não deve ser confundido com o individualismo capitalista e sua atividade mental para si, em sua ânsia de afirmar seu status econômico. Em suma: a força viva do indivíduo, o impulso criativo do eu, reside justamente nas tensões sociais, na ideologia cotidiana do nós. A função da linguagem não é a expressão (do eu), mas a comunicação (com o nós). Os interlocutores (locutor, ouvinte, escritor, leitor...) são reais, sociais e ideológicos. As enunciações também.

A questão que se coloca é: na pluralidade da composição dos diálogos, como estudar as diferentes formas de enunciação? Como realizar um exame socioideológico da dinâmica do diálogo? Para Bakhtin (2006, p. 146): 
...de todas as formas da língua, as formas sintáticas são as que mais se aproximam das formas concretas da enunciação, dos atos da fala. [...] As formas sintáticas são mais concretas que as formas morfológicas ou fonéticas e são mais estreitamente ligadas às condições reais da fala.

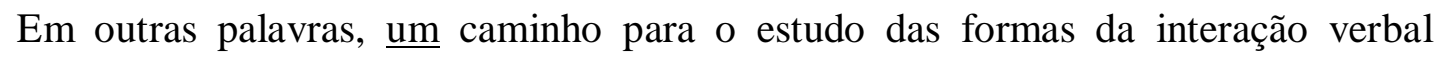
realiza-se na gramática (sintaxe), em particular no estudo do discurso citado. Por que esse foco no discurso citado? Porque ele é uma evidência do diálogo, ele pode mostrar a valoração, o processo apreciativo que sofre uma enunciação. Por exemplo: determinada afirmação de uma pessoa é reorientada de forma dogmática, impessoal, monumental, mitológica? Ou na transposição ela é diluída, enfraquecida, criticada e comentada por aquele que a utiliza? A reconstrução adapta o conteúdo de forma objetiva, linear, íntegra e autônoma? Ou intencionalmente deixa evidente o titubear das deliberações da pessoa citada? Ou seja, como a palavra e a personalidade do falante são redirecionadas? E qual a função ideológica dessas diferentes formas analíticas, valorativas, de re-enunciação?

Deve ficar claro que essas refrações diversas do discurso de outrem se fundamentam para além do quadro da sintaxe, pois suas criações são regidas pelas regras sociológicas (BAKHTIN, 2006, p. 27). Porém, isso não impede seu estudo. Analisar tal regência é estudar a prática, o mecanismo, os tipos e as formas dos discursos: direto, indireto, indireto livre, e suas variantes $^{29}$. As formas como esses discursos são construídos, os esquemas de transmissão do discurso de outrem, são indicadores daquilo que é um consenso ideológico em determinado grupo social.

Com isso, a metodologia de estudo das leis dialógicas consiste em examinar as tendências dos esquemas padronizados (socialmente pertinentes, aprovados) para a apreensão do discurso citado - e entender qual a função ideológica do uso desses esquemas em determinado contexto. Por exemplo, estudar qual o itinerário histórico do discurso citado dentro do discurso narrativo da criação cultural literária, pois isso reflete os conflitos de valores da infraestrutura. Atentando sempre para o fato de que a comunicação na vida cotidiana é extraordinariamente mais rica e plural do que suas especificidades relacionadas

\footnotetext{
${ }^{29}$ Um exemplo banal: Einstein aparece como personagem de um conto. Em certo momento ele afirma: “Eureca! A gravidade não é uma força invisível que atua à distância. Ela é um deslizar de corpos no espaço-tempo curvo!". Uma transposição estranha desse discurso direto para o indireto seria: "Einstein disse eureca, que a gravidade não é uma força invisível que atua à distância, que ela é um deslizar de corpos no espaço-tempo curvo". A estranheza indica que a adaptação implica em uma análise não apenas gramatical, mas também estilística: "Einstein ficou entusiasmado. Afinal, havia percebido que a gravidade não era uma força que atua à distância, mas um verdadeiro deslizar de corpos no espaço-tempo curvo"; ou ainda, "Einstein concluiu que a gravidade não é uma força invisível que atua à distância, pois ela é um deslizar de corpos no espaço-tempo curvo". A interpretação epistemo-ideológica de cada possível abordagem, em seu respectivo contexto narrativo circundante, revelará diferentes nuances das ideologias presentes nas condições de comunicação socioverbal.
} 
aos diferentes domínios de criação ideológica formalizada (a ciência, a religião, a literatura, a imprensa...). A significação mais bem delimitada que determinado signo adquire dentro de um domínio específico (o científico, por exemplo), e que ganha força em seus produtos (tecnológicos, textuais...), possui um caráter diferenciado se comparada às inúmeras possibilidades de uso cotidiano do signo. Dessa forma, compreender esse sentido diferenciado é atingir um outro nível de percepção das relações que esse signo estabelece com seus fatores condicionantes específicos.

Outro caminho metodológico para o estudo da apreensão do discurso citado refere-se à percepção dos temas que perpassam certa atmosfera espaço-temporal, concretizando na realidade semiótica (ideológica) o "espírito da época". A cada forma de discurso social corresponde uma temática pertinente; cada gênero linguístico possui seu repertório de sentidos ${ }^{30}$. Existe uma relação íntima entre as diferentes formas de comunicação, as diversas formas consensuais de enunciação e os temas. A hierarquia social de valores exerce influência poderosa, determinante, nas diferentes formas de enunciação (BAKHTIN, 2006, pp. 44:5).

Sistematizando: a infraestrutura determina a estratificação da sociedade. Sua distribuição hierárquica dos indivíduos condiciona a comunicação verbal. Esse condicionamento materializa-se nos possíveis temas e formas do discurso. Portanto, a liberdade subentende a concretização desse caminho como uma avenida de mão dupla. Subentende a percepção da dinâmica do processo dialético que regulamenta a comunicação. Ou seja, a emancipação realiza-se no domínio da palavra (nessa frase, a ambiguidade do termo domínio é proposital).

Em Matrix, essa questão se materializa, pois dominar a realidade virtual é dominar a linguagem virtual, os concretos programas dos computadores. Quando alguém aprende a controlá-los, seu código verde se distorce, revelando a interferência naquilo que antes era privilégio do sistema.

Resumindo: a língua, a consciência, a compreensão e a significação estão todas em inter-ação, inter-relação dinâmica, instável, estreita, vivaz. São todas de natureza real, material, objetiva. Interindividual, coletiva, cultural, histórica. Ideológica, valorativa. Em seus processos ininterruptos e conjuntos, populares, convergentes, mutuamente dependentes, afetam e são concomitantemente afetadas pelas variações da estrutura social. Logo, devem ser explicadas com base nos fatos socioideológicos.

\footnotetext{
${ }^{30}$ Freitas (2002, p. 136) esclarece esse ponto ao afirmar: "Morson e Emerson mostram como Bakhtin distingue na enunciação significado e sentido. Significado refere-se ao significado abstrato, dicionarizado, que é reconhecido pelos lingüistas. O sentido é o significado contextual, que aparece no livro Marxismo e filosofia da linguagem como tema. Consideram imprópria essa denominação por confundir-se com tema empregado para referir-se a assunto ou idéia". Os autores citados referem-se à obra: MORSON, G. S. \& EMERSON, C. Mikhail Bakhtin. Creation of a prosaics. Stanford: Stanford University Press, 1990.
} 
A relação entre realidade, pensamento e linguagem é íntima, mutável. Para Bakhtin, a dialética entre a realidade material (a infraestrutura socioeconômica), o universo das palavras, e o pensamento (verbal e não verbal) parece muito menos tímida se comparada à concepção do segundo Wittgenstein. Os corpos físicos não são necessariamente simbólicos; as palavras não são necessariamente signos ideológicos; e, imaginando um choque de culturas, percebemos que a linguagem e o pensamento de uma delas não encontram necessariamente um amparo real na infraestrutura da outra. Mas onde a realidade material, a semiótica e a consciência convergem em ideologia é possível a ação do ser humano. Nesse sentido, a esperança reside na confiança no processo, na percepção de que:

...a verdade só é eterna enquanto evolução eterna da verdade (BAKHTIN, 2006, p. 202).

\section{III.3 - COMPARANDO-OS}

Com esses dois autores pudemos combater alguns mitos que distorciam nossa visão sobre o ato educativo. Em primeiro lugar, é possível verificar que nenhum deles considera a língua como um mero decalque da realidade. Bakhtin e em especial o segundo Wittgenstein entendem que essa concepção é uma particularidade de uma visão muito mais rica dos processos linguísticos cotidianos. Por isso mesmo, eles acertadamente valorizam a fala popular.

Ambos afirmam que estudar a linguagem e a compreensão com tendências transcendentais é perder-se em uma confusão desnecessária, equivocada. Concordam que a linguagem deve ser estudada em sua função: no uso que se faz dela no cotidiano. Um deles sistematiza tal uso buscando os jogos de linguagem e o outro buscando as diferentes formas de discurso nas enunciações. O primeiro procura entender a intenção por trás de cada jogo, o segundo a ideologia por trás de cada discurso citado. Nos dois casos, o meio circundante desempenha papel fundamental.

Se para o segundo Wittgenstein e para Bakhtin (2006, p. 52) "a significação é a função do signo", isso implica dizer que ela não pertence a um universo escondido, subterrâneo, mas evidente, concretizado na superfície. Poderíamos dizer que, para ambos, a função da filosofia é colocar a linguagem "em pratos limpos", realizar um saneamento intelectual. Ou seja, aprender não se resume a compreender a lógica gramatical interna de uma língua, mas compreender o que está nas entrelinhas, os propósitos, a relação ideológica que determinada linguagem possui com o contexto sócio-histórico. Portanto, não é 
compreender a sintaxe de um jogo de linguagem ou de uma expressão semiótica, mas buscar entender a relação dessa sintaxe com as condições reais da comunicação.

Isto é, Wittgenstein também considera a língua uma instituição com sua prática ideológica delimitada historicamente. E o que significa aprender tal instituição? Significa: aprender seu funcionamento.

"Aprender" significa: ser levado a poder fazê-lo. E pergunta-se qual é o critério válido para afirmar que alguém seja capaz disso (WITTGENSTEIN, 1999, p. 121).

O que lhe faz afirmar que só faz sentido avaliar se um jogo de linguagem está sendo usado de forma correta ou equivocada em certo contexto, e nada mais. E é aqui que o segundo Wittgenstein se afasta de Bakhtin, o que nos leva a concordar com este, quando afirma:

De fato, a forma lingüística, como acabamos de mostrar, sempre se apresenta aos locutores no contexto de enunciações precisas, o que implica sempre um contexto ideológico preciso. $\mathrm{Na}$ realidade, não são palavras o que pronunciamos ou escutamos, mas verdades ou mentiras, coisas boas ou más, importantes ou triviais, agradáveis ou desagradáveis, etc. A palavra está sempre carregada de um conteúdo ou de um sentido ideológico ou vivencial. É assim que compreendemos as palavras e somente reagimos àquelas que despertam em nós ressonâncias ideológicas ou concernentes à vida.

O critério de correção só se aplica à enunciação em situações anormais ou particulares (por exemplo, no estudo de uma língua estrangeira). Em condições normais, o critério de correção lingüística cede lugar ao critério puramente ideológico: importa-nos menos a correção da enunciação do que seu valor de verdade ou de mentira, seu caráter poético ou vulgar, etc. A língua, o seu uso prático, é inseparável de seu conteúdo ideológico ou relativo à vida. Para se separar abstratamente a língua de seu conteúdo ideológico ou vivencial, é preciso elaborar procedimentos particulares não condicionados pelas motivações da consciência do locutor (BAKHTIN, 2006, pp. 98:9).

Que é o que acontece na educação bancária. Vale ressaltar que a concepção do segundo Wittgenstein é muito frutífera, mas preferimos a concepção de Bakhtin. Isso porque, na práxis pedagógica, mais do que pensar como uma palavra é empregada, deve-se questionar também: por que essa palavra? Qual seu propósito ideológico em determinado contexto? Que mito opressor ela sustenta? Como ele distorce a realidade? Que possibilidades de emancipação ele carrega? Não se trata apenas de interpretar, descrever e aprender a relação entre a linguagem e o mundo, mas de atuar na linguagem e no mundo.

É certo que Wittgenstein é um filósofo que busca a liberdade. Mas ele quer libertar da linguagem, e não pela linguagem, como é o caso de Bakhtin. Por isso, concordamos em muitos pontos com Wittgenstein, salvo no escasso caráter político-ideológico de suas 
reflexões. Nesse ponto, a complementação de Bakhtin é fundamental. Afinal, "toda prática educativa é ideológica” (MARTINS, 2009, p. 261).

A nosso ver, a concepção de linguagem de Wittgenstein é pragmática, enquanto que, para Bakhtin, sua dialética faz dela uma práxis. E só enquanto práxis a palavra "realmente significa e é responsável por aquilo que diz” (BAKHTIN, 2006, p. 203).

Buscaremos agora uma sustentação teórico-experimental para a perspectiva de Bakhtin utilizando as reflexões de Vygotsky. Provavelmente esse não seria o caminho adotado por ele. Mas, para nossos propósitos educacionais, é fundamental embasar a visão de mundo que estamos construindo e as cogitações anteriores na psicologia da aprendizagem.

\section{III.4 - Lev S. Vygotsky: A PSiCologia Sociointeracionista da APREndizagem}

Nascido na Bielo-Rússia, Vygotsky (1896-1934) foi um psicólogo preocupado com a intervenção do professor no processo de aprendizagem dos alunos. Sua linha de raciocínio sustenta-se na seguinte premissa: a interação entre o sujeito e o mundo é mediada (é indireta) por dois instrumentos distintos - os artefatos do universo material; e, os signos do universo psicológico.

Por conta disso, ele diferencia uma inteligência prática (pela qual a atuação no mundo resume-se a tentativas descontroladas, impulsivas, baseadas na percepção das possibilidades concretas disponíveis no campo de visão imediato); e, uma inteligência simbólica (por meio da qual a atuação no mundo é mediada pelos signos, instrumento que permite a elaboração e a organização de um plano de ação).

Isso não significa que o uso de utensílios e a fala sejam independentes. Segundo Vygotsky (1994, p. 29), existe "uma integração entre fala e raciocínio prático ao longo do desenvolvimento", e ambos são importantes constituintes de uma mesma função psicológica complexa, dinâmica, que inclui a percepção, as operações sensório-motoras, a atenção... E mais, a atividade cognitiva não se resume ao uso de artefatos e de signos (1994, p. 72). Por isso ele separa o pensamento em verbal e não verbal, com este último mais abrangente que a categoria inteligência prática.

Em um diálogo com Zanetic, alguns anos atrás, ele fez uma afirmação com a qual concordamos plenamente. A importância da inteligência prática para a inteligência simbólica resultou em uma das cenas mais primorosas da história do cinema. Em 2001 - Uma odisséia no espaço, de Stanley Kubrick, um monolito de origem desconhecida supostamente estimula o início do uso de artefatos pelos hominídeos. É a "aurora do homem”. É o início de sua ação- 
reflexão-ação com a natureza, da construção de seu diálogo inteligente com o mundo. Um desses hominídeos contempla e maneja um osso como instrumento, e acaba por arremessá-lo para cima. Tal osso, girando, dá lugar a um satélite artificial em órbita ao redor da Terra! Uma elipse temporal que toca a essência da questão, ligando a origem do uso de artefatos ao salto da curiosidade verbalizada do homem - lançando-o para além da "última fronteira" de entendimento-ação com o universo: o espaço cósmico.

Vygotsky distingue na psicologia: as funções elementares, de origem biológica, caracterizadas pelo estímulo ambiental e a resposta imediata; e, as funções complexas, de origem sociocultural, nas quais o estímulo é autogerado, ativa e artificialmente, pela intermediação dos signos. Elas não são autônomas. Tais funções (ou processos) impulsionamse mutuamente durante o desenvolvimento intelectual.

Quando a fala e o uso de signos se atrelam à ação, esta se transforma, possibilitando ao indivíduo planejar seu próprio comportamento e controlar o ambiente. Dialeticamente, isso faz com que pensamento e linguagem, em sua interdependência, também se modifiquem. Modificada a linguagem, altera-se também a percepção. Se o indivíduo não estiver ativamente engajado, o signo não lhe fará sentido. Podemos falar de uma percepção verbalizada dessemelhante da percepção visual. Nesse processo espiralado histórico (certo nível de percepção verbalizada do mundo $\rightarrow$ atuação no mundo $\rightarrow$ nível superior de percepção verbalizada...), o ser humano consegue emergir de sua situação, abstraindo - por meio dos signos - soluções para os problemas que lhe afligem. Por exemplo, a emersão de sua própria condição espaço-temporal evidencia-se na linguagem pelos diferentes tempos verbais!

Outro exemplo: a fala egocêntrica das crianças (um embrião da fala interior) indica as dificuldades cognitivas frente aos problemas que se lhe apresentam. Sua manifestação cresce simultaneamente ao esforço ativo da criança para resolver a situação-problema. Aos poucos, a abstração simbólica passa de análise da situação para planejamento da ação, sendo finalmente incluída na própria solução como instrumento de atuação no mundo (VYGOTSKY, 1994, p. 34). Estímulos secundários auxiliam nesse processo de desenvolvimento de uma fala denotativa, elementar, para uma fala instrumental, conotativa, complexa.

Quando analisado dinamicamente, esse amálgama de fala e ação tem uma função muito específica na história do desenvolvimento da criança; demonstra, também, a lógica da sua própria gênese. Desde os primeiros dias do desenvolvimento da criança, suas atividades adquirem um significado próprio num sistema de comportamento social e, sendo dirigidas a objetivos definidos, são refratadas através do prisma do ambiente da criança. O caminho do objeto até a criança e desta até o objeto passa através de outra pessoa. Essa estrutura humana complexa é o produto de um processo de 
desenvolvimento profundamente enraizado nas ligações entre história individual e história social (VYGOTSKY, 1994, p. 40).

Como vemos, nesses dois universos (o social e o individual), a fala tem duas funções interligadas no significado das palavras: a comunicativa (fala socializada, interpessoal, interpsicológica) e a cognitiva (fala interior, intrapessoal, intrapsicológica). Isto é, além da função de refletir o mundo exterior, inerente à linguagem, existe também uma função planejadora da fala, dependente da lembrança mediada por signos. Nesta fala interna, o uso funcional das palavras para classificar, escolher, associar, deduzir..., enfim, refratar o mundo, permite uma compreensão generalizada do funcionamento deste, melhorando o desempenho pessoal na resolução de problemas. Esses usos indicam os processos psicológicos superiores. É essa capacidade de circulação restrita ao universo abstrato que possibilita ao homem, por exemplo, emergir do instante imediato, transitando semioticamente pelo tempo, relembrando o passado e antecipando o futuro. Resumindo, Vygotsky (1994, p. 38) concebe:

....a atividade intelectual verbal como uma série de estágios nos quais as funções emocionais e comunicativas da fala são ampliadas pelo acréscimo da função planejadora.

Isso não quer dizer que a fala interior surge antes da fala exterior, nem que elas são desconectadas. As formas de transição entre aquilo que é biologicamente dado e o culturalmente adquirido são inúmeras. Algumas experiências mostram que primeiro "a criança se torna capaz de subordinar seu comportamento às regras de uma brincadeira de grupo, e que somente mais tarde surge a auto-regulamentação voluntária do comportamento como uma função interna” (VYGOTSKY, 1994, p. 117). É o diálogo social que é internalizado no desenvolvimento cognitivo da criança. As palavras, regras gramaticais, etc., não eclodem de dentro para fora, mas são absorvidas ativamente ${ }^{31}$, de fora para dentro. Para Vygotsky (1998, p. 24) a origem dos signos é social, e o curso do desenvolvimento do pensamento se dá na seguinte sequência: primeiro fala social, depois egocêntrica, e depois fala interior.

Reforçando: isso não significa dizer que incorporar signos é apenas memorizar nomes, mas também habituar-se às lógicas gramaticais, etc., o que leva algum tempo. Durante a vida, a relação entre o pensamento, a linguagem e a realidade se altera! De início, a criança possui uma fase de pensamento sem língua, pré-verbal, e, com o tempo, desenvolve uma fala sem introspecção, pré-intelectual. Aos poucos, o desenvolvimento cognitivo torna possível o uso da linguagem como instrumento lógico e analítico do pensamento. O pensamento torna-se

\footnotetext{
31 “...a alteração provocada pelo homem sobre a natureza altera a própria natureza do homem” (VYGOTSKY,
} 1994, p. 73). 
verbal e a fala racional (VYGOTSKY, 1998, p. 54). Pensamento e linguagem se atrelam, permitindo a elaboração de estratégias simbólicas para controlar o mundo e o próprio comportamento de acordo com sua filtração da realidade.

Para o adulto, predominantemente pensar é abstrair o quadro geral, é transitar livremente pelo universo semiótico. No entanto, na infância, pensar significa lembrar, rememorar fatos e objetos isolados. Para o adolescente essa direção se inverte, "lembrar significa pensar. Sua memória está tão 'carregada de lógica' que o processo de lembrança está reduzido a estabelecer e encontrar relações lógicas; o reconhecer passa a consistir em descobrir aquele elemento que a tarefa exige que seja encontrado" (VYGOTSKY, 1994, p. 67).

O Enigma de Kaspar Hauser, filme de Werner Herzog baseado em fatos reais, deixa tais reflexões evidentes. Kaspar Hauser (1812-1833) viveu em cativeiro até a juventude. Sem contato com outros humanos, não desenvolveu a fala! Porém, assim que é levado para um meio social rico, plural, vivo, dialógico, ele aos poucos interioriza a fala social. Certamente isso não significa que ele não pensava, mas que sua percepção verbalizada da realidade era deficitária - vide sua incapacidade de diferenciar seus sonhos de sua vida diária.

Tendo em vista as considerações de Vygotsky, em que se baseia seu método de pesquisa psicológico? Afinal, se a vida é um processo, se a relação entre biografia e biologia é dinâmica, se o homem ao transformar a natureza transforma sua própria natureza, como examinar a história do desenvolvimento da atividade mental do sujeito?

A essência do método é clara: não se pode estudar o processo matando o processo! O estímulo-resposta não deve estagnar, cristalizar, mas incitar. O exame não deve incentivar o comportamento mecanizado, automático, a reprodução de um produto. Não se deve partir do princípio de que um estudo psicológico objetivo é aquele que não interfere no fenômeno, apenas descrevendo-o superficialmente, prendendo-se à sua aparência externa imediata, enumerando e associando respostas quantitativas, elementares, atomísticas. Do ponto de vista do sujeito, em experimentos organizados dessa forma, nem a sequência de estímulos nem a conexão entre estímulos e respostas têm significado.

O método vygotskyano não intenta examinar a introspecção, mas o desenvolvimento psicológico: meios e métodos simbólicos que o sujeito desenvolve para organizar seu próprio comportamento. Portanto, seu método é dialético e deve: provocar; criar artificialmente um processo rico ao longo do tempo; reconstruir os comportamentos fossilizados dificultando seu uso; procurar mudanças qualitativas no comportamento, buscando a origem dessas mudanças, sua gênese, sua explicação dinâmico-causal na história do indivíduo, da espécie e da sociedade (VYGOTSKY, 1994, pp. 77:99). 
É evidente que toda essa reflexão teórico-metodológica tem implicações educacionais. Inclusive porque, baseado nelas, Vygotsky critica três concepções recorrentes da relação entre desenvolvimento mental e aprendizado. A saber (1994, pp. 103:9):

1- O desenvolvimento é pré-requisito para o aprendizado. Eles são independentes, e o aprendizado é externo e não afeta o desenvolvimento. Quando o desenvolvimento mental atinge certo nível, a aprendizagem "está livre" para avançar. A maturação biológica precede e é uma pré-condição do aprendizado.

2- Aprendizado é o mesmo que desenvolvimento. É acumular, alterar ou substituir um reflexo condicionado, uma resposta inata, um hábito de conduta, uma tendência comportamental.

3- O aprendizado é um processo de desenvolvimento, e o desenvolvimento depende da maturação. É uma combinação das visões anteriores. De alguma forma, um alimenta o outro, mas a natureza da interação não é esclarecida. Nessa concepção, incluem-se aqueles que afirmam que a disciplina formal garante a transferência da capacidade intelectual. Em outras palavras, força-se a aprendizagem de um assunto específico, mesmo que irrelevante para a vida diária do estudante, pois isso garante e capacita (de alguma forma secreta) o desenvolvimento mental como um todo. Logo, aprendizagem e desenvolvimento não coincidem. Aprender algo específico possibilita o desenvolvimento mental de outras capacidades.

Para criticar tais concepções, Vygotsky elabora um conceito valioso (1994, p. 110):

Para elaborar as dimensões do aprendizado escolar, descreveremos um conceito novo e de excepcional importância, sem o qual esse assunto não pode ser resolvido: a zona de desenvolvimento proximal.

Premissa: existem diferentes níveis de desenvolvimento. Questão: como combinar a aprendizagem com esses níveis? O caminho é atentar para dois deles. O nível de desenvolvimento real, que é o nível mental atual do sujeito, seu desenvolvimento já completado; e, o nível de desenvolvimento potencial, que é o nível que ele pode atingir ao ser orientado por alguém mais capacitado. Destarte, o foco não é o nível atual do indivíduo, o que ele já consegue fazer por si mesmo, independentemente, mas aquilo que ele pode vir a fazer sozinho, ainda que nesse processo ele dependa da interação com o outro. Não se olha para o sujeito retrospectivamente, mas prospectivamente, auxiliando-o nos momentos críticos, focando-se no que está efervescente e pode vir a se consolidar. 
A zona de desenvolvimento proximal é a distância entre esses dois níveis, em que as funções cognitivas ainda não amadureceram, mas já estão presentes em um estado embrionário e em processo de maturação. "Essas funções - afirma Vygotsky (1994, p. 113) poderiam ser chamadas de 'brotos' ou 'flores' do desenvolvimento, ao invés de 'frutos' do desenvolvimento". Essa zona subsidia a atuação pedagógica. A zona de desenvolvimento proximal de hoje é o nível de desenvolvimento real de amanhã (1994, p. 113). A aprendizagem "puxa" o desenvolvimento, que permite novas aprendizagens, que irão puxar... Cabe ao educador "dar o empurrãozinho"; atuar deliberadamente no aprendizado e não rebocar o desenvolvimento, tendo sempre em mente que, quando um aluno aprende um conceito, ele não absorve o conceito já pronto, pois este passará por um processo.

Em outras palavras, a zona de desenvolvimento proximal é uma porta de entrada à dinâmica do espiralado processo do aprendiz. Estando ele engajado no problema, as possibilidades de ação são variadas: dar pistas, iniciar a solução e pedir o prosseguimento, demonstrá-la e requisitar a repetição... Atentando para o fato de que o observar-e-fazer, o auxílio concreto pela imitação, não deve ser um fim em si mesmo, mecânico, mas um meio para atingir um objetivo, um meio para aprender (mediado por um passeio pelo universo simbólico) alguma regra de funcionamento da cultura (VYGOTSKY, 1994, p. 116).

O que deve ficar claro é: o estudante necessita encarar o problema enquanto tal. É frente ao desafio, é na busca de soluções que a linguagem se sacode, que o signo ganha significado, que sua percepção verbalizada encontra seus limites e tenta se rearranjar, inclusive procurando, no diálogo e na interação social, novos caminhos para o enfrentamento do problema. A inteligência é a capacidade de beneficiar-se da instrução (BRUNER, 1998, p. xi).

Essa mudança na estrutura do comportamento da criança relaciona-se às alterações básicas de suas necessidades e motivações. [...] Novas motivações, socialmente enraizadas e intensas, dão direção à criança (VYGOTSKY, 1994, pp. 48:9, negrito nosso).

Não se pode negar as necessidades do indivíduo. A separação entre intelecto e afetovolição é um equívoco. A necessidade é o motivo da ação. Sem propósito, não há ação, não há aprendizagem, não há desenvolvimento. Se há a necessidade, enfrenta-se a dificuldade. Se não há a necessidade, resigna-se na dificuldade. "Querer é poder". São as necessidades que nos dizem quais são os incentivos eficazes para colocar o sujeito em ação (VYGOTSKY, 1994, pp. 121:2). Distanciar o afeto do pensamento impede a percepção de como o pensamento dirige o desejo, dinamicamente. Impede inclusive a maturação dessas necessidades. 
Daí ser fundamental conhecer a situação social do sujeito $e$ o sujeito para preparar uma atividade pedagógica adequada. Afinal, o peão é a peça mais importante do jogo de xadrez...

Aliás, existe uma tensão entre as necessidades que só podem ser contempladas no futuro e as aspirações de gratificação imediata. Mais do que satisfazer a um desejo súbito, a aprendizagem deve preencher as necessidades do ser. O prazer é consequência da aprendizagem, e não seu ponto de partida, um mero estímulo barato. Se a atividade se resumir à busca da satisfação de um prazer instantâneo, saciá-lo prontamente encerra o processo. A necessidade permite sentir prazer pelo processo, e não apenas consumir o prazer como um produto. É na necessidade de libertar-se da própria ignorância, no profundo prazer em criar e aprender, que reside a essência do: ser mais é saber mais, não ter mais.

Sem esse cuidado, sem a preocupação com uma aprendizagem relevante à vida, sem uma intervenção competente capaz de incutir o desejo pelo desafio, o tédio se apossará dos alunos e as suas personalidades, violentadas, não desabrocharão.

Para Vygotsky (1994, p. 139), o ensino que enfatiza a mecânica da escrita ou da leitura, a repetição compulsiva, acaba por obscurecer a linguagem, matando-a, impossibilitando uma comunicação verdadeira, comprometendo o processo de significação, a aprendizagem e, consequentemente, o desenvolvimento mental. Vygotsky (1998, p. 105) cita um exemplo de Tolstoi que, após tentar ensinar crianças camponesas dessa forma equivocada, concluiu:

...é impossível explicar o significado de uma palavra... Quando se explica qualquer palavra, a palavra "impressão", por exemplo, coloca-se em seu lugar outra palavra igualmente incompreensível, ou toda uma série de palavras, sendo a conexão entre elas tão ininteligível quanto a própria palavra.

[...]

Quando ela [a criança] ouve ou lê uma palavra desconhecida numa frase, de resto compreensível, e a lê novamente em outra frase, começa a ter uma idéia vaga do novo conceito: mais cedo ou mais tarde ela... sentirá a necessidade de usar essa palavra - e uma vez que a tenha usado, a palavra e o conceito lhe pertencem... Mas transmitir deliberadamente novos conceitos ao aluno... é, estou convencido, tão impossível e inútil quanto ensinar uma criança a andar apenas por meio das leis do equilíbrio.

O que nos leva ao ensino de conceitos científicos. Em primeiro lugar, algumas das investigações de Vygotsky mostraram que "a formação de conceitos é um processo criativo, e não um processo mecânico e passivo; que um conceito surge e se configura no curso de uma operação complexa, voltada para a solução de algum problema; e que só a presença de condições externas favoráveis a uma ligação mecânica entre a palavra e o objeto não é suficiente para a criação de um conceito" (1998, p. 67). Isto é, se o meio ambiente não estimula o intelecto, os estágios mais elevados de raciocínio serão atingidos (se o forem) com 
grande atraso (1998, p. 73). Mas, para nós, sua conclusão mais chocante é a seguinte: os conceitos espontâneos - aprendidos na história "extraescolar" do sujeito - não são substituídos pelos conceitos científicos aprendidos na escola. A aprendizagem de um tipo de conceito afeta e é afetada pela aprendizagem do outro. A diferença é que os conceitos científicos e sua aprendizagem possuem um caráter sistemático (1998, p. 107). Sistematização que, internalizada, impulsiona o desenvolvimento cognitivo e a tomada de consciência em relação aos conceitos utilizados.

Agora é possível avaliar, em retrospecto, como Vygotsky se distancia daquelas três concepções citadas. Desenvolvimento não é aprendizagem. "O primeiro cria as potencialidades, o segundo as realiza" (1998, p. 117). Existe uma unidade, mas não uma identidade entre esses processos. Aprender não é completar uma caminhada, mas dar os primeiros passos de uma jornada. As capacidades intelectuais não são biologicamente determinadas, mas socialmente facilitadas (JOHN-STEINER; SOUBERMAN, 1994, p. 168). O aprendizado adequadamente organizado, socialmente intermediado, afeta e desperta vários processos internos de desenvolvimento das funções psicológicas culturalmente organizadas (VYGOTSKY, 1994, p. 118). Isto é, realidade, pensamento e linguagem (incluindo a científica) combinam-se dinamicamente, retroalimentam-se e ganham um sentido no contexto da existência dos homens e mulheres que buscam lidar com as regras do grande jogo da vida.

Concluindo, foi estudando a psicologia sociointeracionista de Vygotsky que esclarecemos em nossa mente a dinâmica da internalização dos signos sociais de que nos fala Bakhtin. Ambos acreditam que a compreensão é um processo ativo e que os signos são culturais, compartilhados e organizados por regras sociais. Por esse motivo valorizam a fala cotidiana - repleta de contradições existenciais e dilemas ideológicos - em lugar de uma língua abstrata e distante. É impressionante também o quanto eles coincidem na percepção da importância da linguagem para o desenvolvimento e a liberdade do ser. É pela aprendizagem cultural da linguagem que desenvolvemos funções cognitivas complexas essenciais para a perene busca de uma liberdade plena. E, se quisermos incentivar esse processo, é premente revolucionarmos as práticas massacrantes da educação bancária.

\title{
SOBRE A ESTERILIDADE
}

\author{
A árvore que não dá frutos \\ É xingada de estéril. Quem \\ Examina o solo? \\ O galho que quebra \\ É xingado de podre, mas \\ Não havia neve sobre ele? (BRECHT, 2000, p. 141).
}




\section{Capítulo IV}

\section{SINTETIZANDO}

$O U$

'Nós'

Um ser humano é como um romance: até a última página não se sabe como vai terminar.

Ou não valeria a pena lê-lo...

Eugene Zamiatin, 1983, p. 154.

Não existe uma revolução final; as revoluções são infinitas.

Idem, p. 166.

...importa que eu não queira que outros queiram por mim, se quero querer por mim mesma...

Idem, p. 195.

Digressionamos, nos capítulos anteriores, por diversos autores. Desde a concepção de homem, realidade e escola de Freire, todos permanentemente reinventando-se, em revoluções contínuas; culminando em Vygotsky, que não ignora o querer dos indivíduos em seu sociointeracionismo.

Neste capítulo, tentaremos articular, amarrar, atar as contribuições de todos aqueles autores em, quem sabe, um único nó. Ou melhor, tentaremos enlaçar nossas leituras de suas contribuições. Daí ser um nó que é, na verdade, "nós". 
Nas últimas páginas abordamos: as críticas de Freire à educação bancária; as perspectivas de vários estudiosos da ciência pelos diálogos suscitados por Zanetic; as filosofias da linguagem de Wittgenstein e Bakhtin; e, a psicologia de Vygotsky. Se esses autores procedem de distintas arenas espaço-temporais, é possível existir um diálogo verdadeiro entre eles? Ou uni-los implica, inevitavelmente, uma distorção que os faria irreconhecíveis?

Para responder tal questão, convém analisarmos algumas poucas particularidades do encontro entre eles para verificar se estamos lidando com um mero contato, um amontoado desconexo, ou com um entrelaçamento realmente articulado, um convite a um diálogo rico.

E fiquemos de sobreaviso: se o diálogo for verdadeiro, o será, sobretudo, por um motivo simples, mas fundamental: todos esses autores possuem uma base materialista dialética e foram, de alguma forma, influenciados pelas ideias de Karl Marx. A única exceção é Wittgenstein, cuja influência procede de pensadores como K. Krauss, A. Schopenhauer e S. Kierkegaard, dentre outros (JANIK; TOULMIN, 1991, pp. 231:2). No entanto, como já o comparamos com Bakhtin, e como nas questões da linguagem preferimos a visão deste, restringiremos nossa discussão desta modesta síntese a este autor.

Relembremos que no primeiro capítulo acompanhamos a argumentação de Freire, afirmando que boa parte da sociedade está baseada em valores deturpados. Deturpados porque desumanizam o homem. Valores que, como uma lenda urbana, espreitam em vozes furtivas dentro de nossas mentes e se espalham inconscientemente - propagando uma hierarquia social desrespeitosa, em que existe quem-sabe-mais e quem-sabe-menos; quem-pode-mais e quempode-menos; quem-tem-mais e quem-tem-menos. Na leitura de Freire, tal hierarquia absolutista reflete-se na instituição escolar. Instituição que retroalimenta a sociedade verticalizada. As consequências dessa situação para a escola são: existe o professor-que-sabe e o aluno-que-nada-sabe; ao invés de uma relação dialógica, há um mero contato monológico; o conteúdo é fragmentado, descontextualizado e distante das situações-limite que aprisionam nossos pensamentos e atitudes ${ }^{32}$.

No segundo capítulo, dialogando com o trabalho de Zanetic, esmiuçamos questões mais específicas do ensino de física. Com ele percebemos que o conteúdo científico ensinado abstém-se das reflexões epistemológicas, aparecendo apenas em eventuais usos da história da ciência reduzidos a um positivismo ingênuo. Abstém-se, também, das questões sociológicas, das questões vitais, existenciais, ou seja, da relação da ciência com a cultura e com a vida. De

\footnotetext{
${ }^{32}$ Não nos esquecemos das exceções, particularmente daquelas emanadas das pesquisas em ensino de ciências campo em que este trabalho também se insere -, levadas às salas de aula por professoras e professores. Mas essas exceções, infelizmente, realçam as consequências destacadas.
} 
uma maneira geral, sua visão de mundo se aproxima da concepção da frase que se segue, extraída do livro que comemora os vinte anos de defesa de sua tese.

Por mais abstrata que a Ciência possa ser, é essencialmente humana em sua origem e em seu desenvolvimento. Cada resultado científico é um fruto da humanidade, uma prova de sua força. [...]. Não existem Ciências Naturais como opostas à humanidade; cada ramo da Ciência ou do saber é exatamente tão natural ou tão humano como se desejar que seja. Reconhecido o profundo interesse humano pela Ciência, o seu estudo chega a ser o melhor veículo do humanismo que pode ser pensado; excluir esse interesse e ensinar o conhecimento científico como exclusivo objeto de informação e de instrução profissional; então o seu estudo, ainda que válido do ponto de vista puramente técnico, perde todo o valor educativo (George Sarton apud LEODORO, 2009, p. 223).

É notável que o trabalho de Zanetic seja propositalmente interdisciplinar, com enfoque especial na literatura, o que lhe aproxima bastante da problematização de Freire, uma vez que as questões existenciais que se apresentam a educandos e educadores não são bemcomportadas, nem compartimentadas. Tal perspectiva plural se encontra também na visão "translinguística" de Bakhtin.

\section{IV.1 - PAulo Freire e Mikhail BakHTin}

Não é tanto a pureza semiótica da palavra que nos interessa na relação em questão, mas sua ubiqüidade social. Tanto é verdade que a palavra penetra literalmente em todas as relações entre indivíduos, nas relações de colaboração, nas de base ideológica, nos encontros fortuitos da vida cotidiana, nas relações de caráter político, etc. As palavras são tecidas a partir de uma multidão de fios ideológicos e servem de trama a todas as relações sociais em todos os domínios. É portanto claro que a palavra será sempre o indicador mais sensível de todas as transformações sociais, mesmo daquelas que apenas despontam, que ainda não tomaram forma, que ainda não abriram caminho para sistemas ideológicos estruturados e bem formados (BAKHTIN apud ZANETIC, 2009, p. 283).

É nessa percepção que esses autores ombreiam: a linha que os une é justamente um cordel político-ideológico. A unidade (e não identidade) entre eles está na percepção da linguagem (incluindo a científica) como instrumento de opressão e, dialeticamente, de libertação. Linguagem que, ao ser ferramenta insuprimível da prática pedagógica, carrega em si visões político-ideológicas. Eles nos elucidam onde determinadas ideologias podem se esconder dissimuladamente, passando despercebidas como instrumento de opressão de professores sobre alunos.

Como manipular a linguagem é manipular o homem (afinal, a maneira de pensar dos indivíduos é uma internalização da "gramática" predominante e seus costumes sociais 
associados), passamos a encará-la com mais cuidado. Tal preocupação é parte fundamental da metodologia freiriana. Em seu pequeno trabalho A importância do ato de ler, Freire (2001, p. 11) fala de:

...uma compreensão crítica do ato de ler, que não se esgota na decodificação pura da palavra escrita ou da linguagem escrita, mas que se antecipa e se alonga na inteligência do mundo. A leitura do mundo precede a leitura da palavra, daí que a posterior leitura desta não possa prescindir da continuidade da leitura daquele. Linguagem e realidade se prendem dinamicamente. A compreensão do texto a ser alcançada por sua leitura crítica implica a percepção das relações entre o texto e o contexto.

Nesse quesito Bakhtin permite-nos visualizar por outro ângulo as reflexões de Freire:

O processo de descodificação (compreensão) não deve, em nenhum caso, ser confundido com o processo de identificação. Trata-se de dois processos profundamente distintos. O signo é descodificado; só o sinal é identificado. O sinal é uma entidade de conteúdo imutável; ele não pode substituir, nem refletir, nem refratar nada; constitui apenas um instrumento técnico para designar este ou aquele objeto (preciso e imutável) ou este ou aquele acontecimento (igualmente preciso e imutável). O sinal não pertence ao domínio da ideologia; ele faz parte do mundo dos objetos técnicos, dos instrumentos de produção no sentido amplo do termo.

$[\ldots]$

Enquanto uma forma lingǘstica for apenas um sinal e for percebida pelo receptor somente como tal, ela não terá para ele nenhum valor lingüístico. A pura "sinalidade" não existe, mesmo nas primeiras fases da aquisição da linguagem. Até mesmo ali, a forma é orientada pelo contexto, já constitui um signo, embora o componente de "sinalidade" e de identificação que lhe é correlata seja real. Assim, o elemento que torna a forma lingüística um signo não é sua identidade como sinal, mas sua mobilidade específica; da mesma forma que aquilo que constitui a descodificação da forma linguiística não é o reconhecimento do sinal, mas a compreensão da palavra no seu sentido particular, isto é, a apreensão da orientação que é conferida à palavra por um contexto e uma situação precisos, uma orientação no sentido da evolução e não do imobilismo (BAKHTIN, 2006, pp. 96:7).

Percebemos, portanto, o quanto o processo de decodificar e compreender ativa e responsivamente um signo (encarado também como algo mutável) é essencialmente diferente da identificação passiva de um sinal estático. Em um caso, temos a valoração, a apreciação ideológica, a interpretação. O decodificador presume o não dito e prepara uma resposta ao enunciado (FREITAS, 2002, p. 136). No outro caso, temos a cega e obediente absorção de normas. Isso nos evidencia que a prática pedagógica, se reduzida ao caráter normativo (morto, estagnado) do ensino da linguagem, é conivente com a coerção. A criatividade enunciativa popular, reflexo de suas angústias existenciais, deve ter espaço na sala de aula. Dialogismo que encontra ressonância na investigação temática e no círculo de cultura de Freire. 
E mais, comparando essa filosofia da linguagem com as epistemologias apresentadas no segundo capítulo, verificamos uma aproximação bastante esclarecedora entre "a coerção da linguagem amenizando a luta de classes em prol de uma sociedade opressora" e o "adestramento dos cientistas normais no paradigma dominante". O que nos remete, novamente, à questão: as reflexões epistemológicas são prejudiciais aos cientistas em formação? E, no caso do ensino médio: as reflexões epistemológicas são prejudiciais ao cidadão em formação?

Para nós, a resposta, em ambos os casos, é negativa. Essas questões revelam falsos empecilhos causados por modismos de pensamento, por paradigmas, por mitos, por vozes institucionais interessadas, conscientemente ou não, na coerção, uma vez que a ciência certamente pode operar como um Aparelho Ideológico de Estado (ALTHUSSER, 1985). Não se pode sabotar o processo de aprendizagem das pessoas sob o falso pretexto de protegê-las. Não se pode negar-lhes o direito de escolha frente aos dilemas ideológicos, aos problemas existenciais e culturais que se lhes apresentam. Nesse sentido, apetece-nos enormemente o anarquismo epistemológico de Feyerabend, principalmente quando ele afirma que:

...a ciência deveria ser ensinada como uma concepção entre muitas e não como o único caminho para a verdade e para a realidade (FEYERABEND, 2007, p. 9).

\section{IV.2 - MIKHAIL BAKHTIN E LEV VYGOSTKY}

Tanto Bakhtin como Vygotsky criticam as concepções psicológicas de suas épocas, tendenciosas ora a um subjetivismo idealista, ora a um objetivismo mecanicista (FREITAS, 1996, pp. 174:7; 2002, p. 71). Desmontados esses reducionismos, esses psicologismos, ambos olham para as questões da psicologia da perspectiva da cultura e da linguagem. Portanto, da intersubjetividade sócio-historicamente delimitada. Da unidade indivíduo-sociedade.

Na questão da internalização das regras dialógicas da comunicação social, da incorporação da ação verbal, Bakhtin e Vygotsky também coincidem ${ }^{33}$. Os dois argumentam que não se pode compreender o pensamento e a linguagem separando-os. Para eles, a viva unidade (não identidade) entre pensamento e linguagem se encontra na significação da palavra. É nela que se localiza a unidade entre a comunicação social e o pensamento individual. Eles também concordam com o fato de que a história social interfere na história individual, e vice-versa,

\footnotetext{
${ }^{33}$ E Freire (1992, p. 66) também: "Todo ato de pensar exige um sujeito que pensa, um objeto pensado, que mediatiza o primeiro sujeito do segundo, e a comunicação entre ambos, que se dá através de símbolos lingüísticos. O mundo humano é, desta forma, um mundo de comunicação. [...] O sujeito pensante não pode pensar sozinho; não pode pensar sem a co-participação de outros sujeitos no ato de pensar sobre o objeto. Não há um 'penso', mas um 'pensamos'. É o ‘pensamos' que estabelece o ‘penso' e não o contrário".
} 
mediante a evolução do material semiótico. Ambos tentam rastrear essa evolução. Para os dois, a percepção verbalizada, engajada, valorativa, refrata os problemas do mundo.

O que pode gerar confusão é a questão das funções da linguagem. Bakhtin defende a função comunicativa da fala, rejeitando o psiquismo metafísico. Vygotsky também o refuta, apesar de seu interesse pela fala interior. A nosso ver, essa é uma daquelas situações para as quais nos alerta o segundo Wittgenstein: os jogos de linguagem utilizados por Bakhtin se originam em sua vertente socioideológica, enquanto os jogos de linguagem usados por Vygotsky são característicos de sua veia psicológica. A confusa nuvem que se forma no encontro desses jogos é uma ilusão, pois o olhar de ambos é guiado pelo sociointeracionismo. Suas ideias se complementam sem a necessidade de grandes cicatrizes, pois suas diferentes concepções conceituais não se contradizem. A neblina é "gramatical", não "semântica", por assim dizer. Ambos afirmam que, no universo adulto, a função da linguagem é instrumental e criadora. Bakhtin focaliza sua discussão no pensamento verbal. Vygotsky é mais minucioso e um ótimo arremate experimental às suposições de Bakhtin, principalmente para os primeiros estágios do desenvolvimento.

No geral, Freitas assinala (1996, p. 172) ser impossível entrar em contato com as ideias de Bakhtin sem repensar a dinâmica da sala de aula:

\begin{abstract}
O que é o aluno para mim? Objeto que observo e sobre o qual derrubo o "meu saber" ou um sujeito com o qual compartilho experiências? Alguém a quem não concedo o direito de se expressar, o direito de autoria? Ou quem sabe, apenas reconheço sua voz quando ela é um espelho da minha? Aceito o seu discurso apenas quando reproduz o meu? O que acontece em minha sala de aula? Ela é um espaço para monólogos ou o lugar onde muitas vozes diferentes se intercruzam? Que tipos de interações aí transcorrem? Falo para um aluno abstrato ou ele existe para mim marcado pelo tempo e espaço em que vive? Conheço o seu contexto, os seus valores culturais? O conteúdo das disciplinas tem a ver com esse meio cultural, com a vida dos alunos? Minha sala de aula é um espaço de vida ou apenas um espaço assepticamente pedagógico?
\end{abstract}

Evidenciando a autenticidade do diálogo entre todos esses autores, vemos que o caráter interacional e inter-racional de suas obras aponta respostas na mesma direção. Se Freitas surgiu com tais perguntas por meio de sua imersão no universo vygotsky-bakhtiniano, Freire as responde com uma densidade, paixão e clareza incríveis em sua Pedagogia da Autonomia (1996). Ele aponta, inclusive, um cuidado para que, ao evitar o autoritarismo, o educador não se esqueça de sua legítima autoridade responsável por manter um clima de aprendizagem no espaço pedagógico. Portanto, hierarquia dialógica que se constitui em dinâmica dialética com a liberdade, e não com equivocada licenciosidade. O que se deve é: 
Estimular a pergunta, a reflexão crítica sobre a própria pergunta, o que se pretende com esta ou com aquela pergunta em lugar da passividade em face das explicações discursivas do professor, espécies de respostas a perguntas que não foram feitas. Isto não significa realmente que devamos reduzir a atividade docente em nome da defesa da curiosidade necessária, a puro vai e vem de perguntas e respostas, que burocraticamente se esterilizam. A dialogicidade não nega a validade de momentos explicativos, narrativos em que o professor expõe ou fala do objeto. O fundamental é que professor e alunos saibam que a postura deles, do professor e dos alunos, é dialógica, aberta, curiosa, indagadora e não apassivada, enquanto fala ou enquanto ouve. O que importa é que professor e alunos se assumam epistemologicamente curiosos (FREIRE, 1996, p. 86).

\section{IV.3 - PAulo Freire e LeV Vygostky}

Gehlen e colaboradores (2008) examinam os trabalhos de Freire e Vygotsky atentos às consequências de suas perspectivas para o ensino de ciências, encontrando aproximações e distanciamentos. Comecemos pelas dessemelhanças. Seriam elas: a gênese do conhecimento; e, consequentemente, o ponto de partida do processo de aprendizagem.

Segundo eles, enquanto Freire aponta como início da aprendizagem o "saber de experiência feito", o cotidiano, a realidade do educando, Vygotsky argumenta que é o caráter sistemático dos conceitos científicos que leva ao desenvolvimento de algumas funções psicológicas superiores, permitindo que o aprendiz tome consciência de suas vivências, de seus conceitos cotidianos, usualmente assistemáticos e inconscientes. Isto é, para Gehlen e coautores, Vygotsky entende que o ponto de partida do conhecimento é a abstração e o seu ponto de chegada é o mundo concreto, enquanto Freire argumenta em sentido contrário.

Não acreditamos que essa diferenciação seja preocupante, mesmo porque, assim como os próprios autores do artigo afirmam, essas são perspectivas complementares. Para nós, quando Freire defende, conforme citamos pouco acima, que a leitura do mundo precede a leitura da palavra, de certa forma entendemos uma convergência com a afirmação de Vygotsky (1998, p. 99) de que:

O adolescente formará e utilizará um conceito com muita propriedade numa situação concreta, mas achará estranhamente difícil expressar esse conceito em palavras, e a definição verbal será, na maioria dos casos, muito mais limitada do que seria de se esperar a partir do modo como utilizou o conceito. A mesma discrepância também ocorre no pensamento dos adultos, mesmo em níveis mais avançados. Isso confirma o pressuposto de que os conceitos evoluem de forma diferente da elaboração deliberada e consciente da experiência em termos lógicos. A análise da realidade com a ajuda de conceitos precede a análise dos próprios conceitos. 
Em outras palavras:

À frase bíblica "No princípio era o Verbo", Goethe faz Fausto responder: "No princípio era a Ação". O objetivo dessa frase é diminuir o valor das palavras, mas podemos aceitar essa versão se a enfatizarmos de outra forma: No princípio era a Ação. A palavra não foi o princípio - a ação já existia antes dela; a palavra é o final do desenvolvimento, o coroamento da ação (VYGOTSKY, 1998, p. 190).

Para nós, tanto Vygotsky quanto Freire acreditam que os seres humanos possuem uma peculiaridade que outros animais não possuem: a plasticidade cerebral. Porém, ela de nada serviria sem o estímulo social. A maturação, o desenvolvimento cognitivo não é um processo passivo. A bem da verdade, a plasticidade é tamanha que, nascendo em países diferentes, aprendemos línguas muito diversas; além de formas de pensar amplamente distintas. Isto é, possuímos particularidades biológicas, mas elas não são autossuficientes. Ao agir e modificar a natureza, o indivíduo modifica a si mesmo e, alterada sua estrutura cognitiva, passa a perceber a natureza de outra forma, o que lhe permite novas possibilidades de atuação - processo cíclico que requer o engajamento pela própria aprendizagem. Por isso, tanto Vygotsky quanto Freire criticam a memorização mecânica e indicam como contraponto um cuidado em preparar atividades criativas influentes nas faculdades cognitivas dos estudantes.

Nesse sentido, Freire e Vygotsky convergem na valorização do conhecimento cotidiano, pois é no dia a dia que descobrimos as necessidades e desejos do ser. Aproximamse também na valorização da escola como intermediária de uma aprendizagem crítica e sistemática. E como a interação social é decisiva para a internalização da cultura, é possível perceber também uma semelhança entre a função dos especialistas para Freire e a dos sujeitos mais capazes para Vygotsky. Para ambos, o papel dessa interação é levar da interação à conscientização, à compreensão de nossa própria compreensão sobre as relações entre os sujeitos e destes para com o mundo. Gehlen e coautores identificam essas mesmas aproximações.

Podemos, finalmente, concluir essa rápida incursão pelas possibilidades de diálogos entre todos esses autores. Aproveitaremos para realizar breves apontamentos sobre as pesquisas citadas na introdução relativas ao uso da ficção científica no ensino de física.

\section{IV.4 - ATANDO-OS EM 'NóS'}

É difícil amalgamar sem deformar, sem mutilar. Mas eis que, aparentemente, isso não foi necessário. De acordo com nossas leituras acima, parece-nos realmente que o diálogo 
entre esses autores é genuíno. E isso, como antecipamos, porque eles compartilham um mesmo útero ideológico: o materialismo dialético. Não são gêmeos idênticos, mas podem ser considerados membros de uma mesma família.

Fato é que por meio deles combatemos muitos mitos que obscureciam nossas tentativas de entender o funcionamento social e escolar. Nossa primeira aprendizagem importante para a confecção dessa dissertação na forma que ela se apresenta - e que não conseguimos delimitar exatamente por meio de qual autor passamos a enxergar o mundo de tal forma - foi a noção de que existem mitos culturais que delineiam nossas formas de pensar-agir.

...toda estrutura social é fundada sobre a crença ou sobre a confiança. Todo poder se estabelece sobre estas propriedades psicológicas. Pode-se dizer que o mundo social, o mundo jurídico, o mundo político são essencialmente mundos míticos, isto é, mundos dos quais as leis, as bases, as relações que os constituem não são dadas, propostas pela observação das coisas, por uma constatação, por uma percepção direta; mas, ao contrário, ganham existência, força, ação a partir de impulsão e repressão; tanto esta existência quanto esta ação são tão mais potentes quanto mais ignorarmos que elas vêm de nós, de nosso espírito (Paul Valéry apud NOVAES, 2010, p. 7).

Foi somente após essa percepção que, a partir daqueles autores, passamos a tecer uma rede teórica para entender o complexo tecido social e atuar no/com o mundo. Todos eles concordam com a máxima de Marx de que o pensamento da classe dominante penetra e deixa sua marca nas várias manifestações sociais e culturais. Todos questionam a estrutura massificante da sociedade. Foi com Freire que compreendemos que a hierarquia social desumana se reflete na escola, com seu saber sedimentado e seu autoritarismo arbitrário, modelador, que alimenta um tédio imbecilizante em alunos amedrontados, subservientes, letárgicos. É um sistema em que nós, desafortunados indivíduos, soterrados por informação, deformamo-nos. Embotados, defendemos o mecanismo que nos deformou. Dominadosdominadores. Controlados-controladores. Criaturas-criadores.

A beleza de um mecanismo está no seu ritmo - constante e preciso como um pêndulo. Mas vós, criados desde a mais tenra infância no sistema Taylor, será que não adquiristes a precisão do pêndulo? (ZAMIATIN, 1983, p. 170).

Segundo Freire, é no reconhecimento de nossa própria ignorância, é na percepção de que somos oprimidos-opressores que se inicia o processo de reconstrução de nós mesmos, a retomada de nossa humanidade, nossa interminável re-educação. Piassi (2007) faz um paralelo entre Freire e Snyders em sua tese, mas não enfatiza justamente este ponto. A nosso ver, quando não reconhecemos a opressão que nos limita e que propagamos oprimindo aos outros, perpetuamos uma prisão para nossas mentes e atitudes. Estagnando nossas ideologias e ações, sabotamos nossa própria curiosidade epistemológica. Justamente por isso Freire 
costura uma metodologia dialógica baseada na problematização das situações-limite que povoam nossas mentes. Dialogismo que não pode confundir liberdade com licenciosidade como parecem perpetrar Gómez (2008) e Palacios (2005). A ordem é necessária no ambiente pedagógico, desde que seja sabidamente dialógica e não absolutamente imposta.

Com os olhos abertos por tais percepções, fomos entender com Zanetic que a ciência é uma instituição social muito poderosa atualmente. Poder que a transforma em vítima da onipotência suplicante de muitos de seus defensores mais ardorosos. Ao invés de fornecer aos indivíduos sua tão exaltada racionalidade, ela serve muitas vezes para afastá-los da esfera das decisões. Embebidos em mitos culturais que - sob uma crosta de símbolos e algoritmos voltados para a mera resolução de exercícios e não a compreensão-atuação com o mundo definem a ciência como incompreensível para leigos, além de detentora da verdade única, acabada e absoluta, submetemo-nos a sua vontade e sua estética de mundo. Míopes, propagamos descriticizadamente seus paradigmas, adotamos o método de pensar defendido ferrenhamente de sobre seu palanque. No álbum Quanta (1997), Gilberto Gil canta:

Se toda coincidência

Tende a que se entenda

E toda lenda

Quer chegar aqui

A ciência não se aprende

A ciência apreende

A ciência em si

Se toda estrela cadente

Cai pra fazer sentido

E todo mito

Quer ter carne aqui

A ciência não se ensina

A ciência insemina

A ciência em si

Se o que se pode ver, ouvir, pegar, medir, pesar

Do avião a jato ao jaboti

Desperta o que ainda não, não se pôde pensar

Do sono do eterno ao eterno devir

Como a órbita da terra abraça o vácuo devagar

Para alcançar o que já estava aqui

Se a crença quer se materializar

Tanto quanto a experiência quer se abstrair

A ciência não avança

A ciência alcança

A ciência em si. 
Sem compreendê-la como construção humana, falível, proposta de alguns para entender aspectos desse mundo, tornamo-nos submissos a um saber que impõe uma “subordinação estética absoluta" (ZAMIATIN, 1983, p. 20).

- Ora, o saber! Esse seu saber não passa de uma covardia. Não discuta, é verdade. O que você está tentando é aprisionar o infinito entre paredes, e fica aterrorizado com a idéia de espiar para fora delas (ZAMIATIN, 1983, p. 50).

Dentre as ciências, alguns mitos sobre a psicologia que recheavam nossa mente precisaram ser abalados para que pudéssemos caminhar com uma proposta pedagógica mais coerente. Mitos estes provenientes de seu nascimento embebido na ideologia dominante, escamoteando os conflitos sociais.

...a dominação de classe no capitalismo não se faz de forma transparente e se exerce mediada pela ideologia da liberdade individual e da igualdade de oportunidades. Para Campos ${ }^{34}$, essa ideologia liberal, construída sobre a noção de liberdade individual e igualdade de oportunidades, funciona como produtora do consenso acerca da justeza do modelo de convivência social do capitalismo liberal, na medida em que as desigualdades provocadas pela divisão de classes e pela propriedade privada são atribuídas à desigual distribuição de dons e aptidões pela natureza. Procurou-se, assim, através do conceito de aptidões como dons naturais, explicar a desigualdade dos indivíduos ocupantes de diferentes lugares na escala ocupacional.

$[\ldots]$

As classificações dos indivíduos, resultantes da aplicação de escalas de inteligência, de testes de IM (Idade Mental) e QI (Quociente Intelectual), serviam, na verdade, como justificativa para a manutenção de uma distribuição dos homens em classes sociais. Os testes pretendiam, pois, explicar a existência de bons e maus alunos, deficientes e normais, tentando justificar o insucesso escolar, atribuindo-o a um problema individual, a um déficit. Os testes psicológicos entraram para a Psicologia pela porta do predeterminismo, reforçando a crença no mito da igualdade de oportunidades. A própria inteligência era considerada, até a primeira metade de nosso século, como uma dimensão geneticamente determinada da capacidade funcional humana, portanto, como um atributo fixo (FREITAS, 2002, pp. 56:7).

Em outras palavras: aprendemos com Vygotsky que as peculiaridades biológicas não determinam o desenvolvimento intelectual de uma pessoa, principalmente porque a maturação cognitiva não é um processo passivo - ela depende da interação social, quando a cultura passa a fazer parte da natureza do indivíduo.

Na verdade, nosso pensamento sobre as aptidões humanas é tão dominado pelo determinismo genético que tendemos a achar que toda atividade humana deva ter um componente genético que cause as variações. No fundo acreditamos que a individualidade humana seria, pelo menos em parte, de

\footnotetext{
${ }^{34}$ CAMPOS, R. H. F. A função social do psicólogo. Educação e Sociedade. CEDES, São Paulo, 16, dez. 1983.
} 
origem genética. Nem preciso dizer que o desempenho mental também deveria ser pelo menos parcialmente genético.

Mas não é verdade. Há um tipo de desempenho mental humano cuja variação não depende de nenhum componente genético. Essa atividade é a linguagem.

$[\ldots]$

Portanto, ao invés de aceitarmos como ponto pacífico a noção de inteligência formulada há mais de um século pelos homens da classe média profissional - ou seja, de que a inteligência humana é propriedade de indivíduos, que alguns têm mais do que os outros, que herdamos nossa cota particular de nossos pais - podemos passar a ver a inteligência como vemos a linguagem: uma propriedade de nossa espécie. Diferenças de inteligência, então, seriam como diferenças de linguagem. Refletiriam diferenças de circunstâncias sociais. Assim como aprendemos línguas, aprendemos a ser inteligentes (SCHWARTZ, 1992, pp. 192:4, grifos nossos).

Foi com Vygotsky que conseguimos entender essa perspectiva. Em primeiro lugar, percebemos que não podemos pensar a psicologia da aprendizagem mais preocupados em criar rótulos do que fornecer meios de incitar o desenvolvimento, pois ela se tornaria instrumento de opressão. No que se refere especificamente ao ensino de ciências, estávamos muito presos à crença de que aprender física levaria inexoravelmente ao desenvolvimento de inúmeras capacidades cognitivas (relacionar, induzir, deduzir, etc.). Aprendemos com Vygotsky que esta obscura influência deveria ser encarada com mais cuidado, principalmente em um ensino mecanizado que massacra o desenvolvimento ao invés de instigá-lo. Tal inferência miraculosa se relacionava a outra crença que sustentávamos: a de que o conhecimento cotidiano deveria ser substituído pelo científico - equívoco que, conforme apontamos na introdução, acomete Palacios (2007) e Borrás (2006); e é combatido por Neves e colaboradores (2000). A derrocada deste mito em nossa mente decorreu de duas percepções. A primeira aprendemos com Zanetic: o conhecimento científico não é $A$ Verdade, e portanto não há porque defender que ele deva suprimir o conhecimento cotidiano. Podemos dizer que essa humildade preparou o terreno para que entendêssemos com Vygotsky que a aprendizagem do conhecimento científico alimenta e é retroalimentada pela aprendizagem do conhecimento diário, e que um não vive sem o outro, tampouco substitui o outro. Aprendizagens em contextos diferentes permitem mudanças conceituais nestes dois âmbitos.

Mas o denominador comum, a base em que assentamos todas essas visões de mundo de forma coesa foi a filosofia da linguagem de Bakhtin. Porém, para entender-lhe a filosofia, tivemos de derrubar alguns mitos profundamente inconscientes que modelavam nossa forma de perceber as relações entre a realidade, o pensamento e a linguagem. Esse processo iniciouse com o primeiro Wittgenstein, a partir do momento em que, com muito esforço, derrubamos 
a crença de que as palavras são etiquetas definitivas, conceitos abstratos que saltam perante o espírito quando lembramos de algo. Assim, com este Wittgenstein passamos a conceber um paralelismo entre a estrutura lógica das proposições e a estrutura lógica do mundo.

Porém tal visão não durou muito, pois, com o segundo Wittgenstein, logo passamos dessa lógica unívoca para uma gramática versátil. Em outras palavras, as proposições não garantem sua veracidade por conta de serem um reflexo do mundo, mas, na verdade, são julgadas como eficientes ou não em meio ao contexto em que são empregadas. É no uso dialógico, e não na relação com o mundo, que elas ganham seu status de verdade. Entendendo isso, passamos a acompanhar Wittgenstein em sua luta filosófica, seu desejo de se libertar dos confusos jogos da linguagem. Foi com Bakhtin que percebemos que essa seria uma luta ingrata; e que, em vez de libertar da, deveríamos buscar nos libertar pela linguagem.

A linguagem está repleta de ideologias. Compreendê-las é o primeiro passo para libertar-se. Atuar na linguagem e no mundo é o necessário complemento.

A sociedade se sustenta em ideologias que definem nossas relações pessoais e a maneira como concebemos e interagimos com a realidade. São molduras ideológicas que sustentam e são sustentadas pelos valores estabelecidos. Isso não quer dizer que elas são invulneráveis. Se as julgarmos inadequadas, podemos mudá-las. Não somos impotentes, nem estamos indefesos, há esperança. E essa esperança é a práxis. A linguagem e a cultura não apenas aprisionam, mas também libertam. O homem não é apenas um fantoche biológico ou um produto do meio, mas também um ator e autor do meio e de si mesmo. E só conseguimos entender essa concepção pela união de todos os referenciais utilizados nos últimos capítulos.

No fim, aqueles autores baseiam suas reflexões em conceitos próximos e, muitas vezes, similares, eventualmente encarados de perspectivas distintas e, mais importante, complementares. Da perspectiva de todos eles - nesta construção do papel dos signos, da ciência, dos educadores e educandos - vislumbramos uma tese muito cara a Marx, presente em suas Teses sobre Feuerbach (1999, p. 14), que afirma que os filósofos, além de produzir diferentes interpretações de mundo, devem fornecer elementos que busquem transformá-lo. Portanto, baseados nesses filósofos da educação, da ciência, da linguagem, da psicologia, buscaremos fornecer uma possível estratégia para auxiliar na transformação pela qual necessita passar a escola - um elemento que será um símbolo de nossa esperança: a ficção científica. 


\section{IV.5 - RETOMANDO O VELHO E O NOVO... E A LIBERDADE}

Confessamos que, de início, estávamos incomodados por contrapor os indivíduos ao sistema, pois parecia-nos que proceder dessa forma seria recorrer a uma entidade abstrata e ilusória para justificar os tropeços dos sujeitos durante a vida. Parecia-nos tolice apelar a uma coerção moral por instituições invisíveis atuantes durante a formação cultural de cada um. Afinal, não existe algo interior que nos diferencia, impedindo que um maquinismo social nos condicione? Acusar o sistema não seria uma forma de retirar a responsabilidade de sobre nossos ombros?

Porém, conforme fomos desvendando os modos de funcionamento da "ordem" social atual, passamos a perceber que não estávamos, como verdadeiros discípulos de D. Quixote, imaginando um moinho de vento, fantasiando sobre algo irreal apenas para extravasar nosso sentimento sobre o mundo. Se o sistema escolar alimenta e é alimentado pelo sistema social, propagando-o; se uma visão mitológica sobre a ciência tem afastado os indivíduos das escolhas críticas; se internalizamos a linguagem e a maneira de pensar da cultura massificante que nos rodeia; tudo isso revela armadilhas que impedem ou atrasam a maturação de funções mentais complexas essenciais para nossa perene busca pela liberdade. Por tudo isso, cremos que um "sistema" não é algo abstrato e intocável, mas uma organização repleta de ideologias evidentes e concretas justamente na linguagem - instrumento sócio-cultural que governa nossas formas de pensar-agir em cada situação histórica. De sobre esse castelo teórico, hoje acreditamos que argumentar em prol de "algo" interior não-manipulável é que seria apelar para abstrações intocáveis. Nem por isso pretendemos permanecer encastelados, isolados nessa visão de mundo, e buscaremos futuramente dialogar com o mundo e com outros autores que se contraponham àqueles que aqui defendemos. Não obstante, por coerência, confeccionaremos o restante deste trabalho de sobre este nosso inacabado (inacabável?) castelo.

De todos os conceitos em que nos baseamos, um dos mais importantes - e que não à toa aparece no título desta dissertação - é a liberdade. Liberdade que subentende um esforço, um domínio das próprias ações, um pensar e repensar criticamente sobre os caminhos passados e futuros. Liberdade que necessita que nos reconheçamos oprimidos, por um lado, e opressores, por outro. Pois somente percebendo que nos tornamos veículos de vozes alheias, que somos portadores de violências, que muitas vezes nos tornamos prisioneiros das circunstâncias, poderemos atuar co-irmanados em busca da emancipação. Pedagogo, cientista, filósofo, escritor, etc., são lugares, posições ocupadas por aqueles que pretendem utilizar alguma "voz" institucionalmente legitimada para discutir a condição humana. Porém, tais 
instituições, na luta pela sobrevivência, muitas vezes "miopizam-se", tornam-se coniventes com maldades. É reconhecendo e transformando essas maldades introjetadas em nossa cultura interior que nos libertaremos. Isto é, libertar-se não é livrar-se $d a$ linguagem, $d a$ religião, $d a$ ciência, do sistema..., mas, em comunhão, livrar-nos pela linguagem, pela religião, pela ciência, pelo sistema... É livrar-nos para mudar: a nós mesmos e ao mundo. Acreditamos ter ficado claro, portanto, que não defendemos um anarquismo ingênuo - acreditamos que a ordem é necessária. E é nessa concepção de liberdade que reside nossa esperança.

Abramczuk (1981), por exemplo, após acertadamente verificar que o ensino de física tradicional contribui para a manutenção de uma sociedade opressora, propõe que a física seja banida do currículo escolar. Uma perspectiva ousada que, a nosso ver, deveria ser discutida seriamente pelo menos uma vez por todos os professores de física. Concordamos com suas críticas à visão de ciência totalitária que nossa cultura propaga, mas discordamos da solução que ele sugere. A escola, em geral, e o ensino de física, em particular, não são ontologicamente brutais. Estão historicamente desumanos; e, se estão, podem mudar. Para nós, Abramczuk crê que livrar-se é livrar-se de. Mas libertar-se não é negar, repudiar, pura e simplesmente, aquilo que nos cega. Aquilo que nos escraviza, que nos impede de saber e ser mais, possui em sua problematização o germe da emancipação, que nos impele a saber e ser mais. Libertar-se é compreender essa dialética, é entender que emancipação e aprisionamento estão intimamente ligados, que um constantemente origina e transforma o outro, como no símbolo yin-yang. Por isso a liberdade é uma busca. Permanente. Não existe uma revolução final...

Devemos cuidar também, ao buscar uma metodologia que promova a liberdade, para não recairmos em uma má interpretação do dirigismo cultural a que alude Cuartas (2007). Não cabe ao professor catequizar em seu narcisismo ideológico, mas problematizar as contradições existenciais, os contrastes ideológicos da cultura do educando, apresentando-lhe visões distintas e - sempre que possível - conflitantes, para que este realize suas próprias escolhas, reconhecendo tais visões como propostas historicizadas de sujeitos e não como verdades absolutas descobertas por gênios.

Em suma, mesmo com todas essas incursões por outros autores, não alteraremos o cerne da metodologia freiriana. A nosso ver, as perspectivas de Zanetic, Wittgenstein, Bakhtin e Vygotsky aguçaram nossa percepção de vários pontos da reflexão de Freire, sem contradizer a sequência das ações pedagógicas por ele engendrada.

Com a tese de Zanetic, além de tudo aquilo que temos citado, aprendemos a apresentar aos educandos visões de autores distintos sobre o assunto em questão, inclusive narrando o contexto cultural dessas visões. Com Wittgenstein aprendemos que o ensino ostensivo das 
palavras é uma ilusão. Com Bakhtin compreendemos que devemos estimular os educandos a interrogar o silêncio, a buscar o não dito sob o dito, pois é no subtexto que reside a ideologia. E tudo isso se complementa com a conclusão de Vygotsky (1998, p. 187) de que "uma compreensão plena e verdadeira do pensamento de outrem só é possível quando entendemos sua base afetivo-volitiva". São várias perspectivas que se reforçam umas às outras na crítica ao ensino doutrinário tradicional, baseado em práticas que esmorecem a ambição dos estudantes. Inclusive, a curiosidade epistemológica de que nos fala Freire pode ser o impulso para a transposição da zona de desenvolvimento proximal de que nos fala Vygotsky (GEHLEN et al., 2008, p. 15). Nesse sentido, como educadores devemos atentar que o querer - socialmente enraizado - é a porta para a curiosidade epistemológica, e é a metodologia que levará da contribuição inicial ${ }^{35}$ do educando para o conhecimento sistemático (ontologicamente contestável), permitindo ao aprendiz usufruir e/ou subverter este conhecimento.

Resumindo: uma palavra dicionarizada é neutra, uma frase em um contexto e com um pretexto, não. A partir do momento em que o professor profere enunciados, sua escolha pedagógica implica um posicionamento político, econômico, social, cultural, etc. Implícito ou explícito, tal posicionamento está, inexoravelmente, feito. Vimos exemplos disso ao utilizar os argumentos de alguns autores. Poderíamos ter utilizado outras leituras de mundo. Mas o que deve ficar claro é: defender que a educação em geral ou o ensino de ciências são neutros, imparciais, é uma ingenuidade, uma ilusão. Pior, é uma quimera conivente com os anseios de uma classe econômica e um grupo cultural restritos. Inocência que pode ajudar a propagar o conformismo social, enevoando o desvelamento da realidade.

Contra essa resignação adotaremos a metodologia freireana, que parte da problematização da relação do indivíduo com o conhecimento. Desta relação entre o novo e o velho, os recortes pedagógicos - e seus valores inextrincáveis, velados ou não - implicam obstáculos. Mattos (2010, p. 147) aguça-nos a percepção sistematizando-os em três eixos:

- Axiológico: é a pertinência de determinado conhecimento para o indivíduo; os valores e fins que ele atribui à informação que se lhe apresenta. Em outras palavras: vale a pena aprender isso? Eu quero aprender isso?

- Epistemológico: relativo às questões gnosiológicas do saber. Ou seja: como eu conheço o mundo? Esse conhecimento é verdadeiro? Quais seus limites?

\footnotetext{
${ }^{35}$ Usualmente utilizam-se os termos: concepções prévias, concepções iniciais, etc. Optamos por adotar a forma "contribuição inicial” para salientar que a voz do educando deve ser ouvida respeitosamente.
} 
- Ontológico: que se refere às questões da essência do conhecimento em si, legitimando sua aprendizagem. Em suma: eu reconheço o conhecimento como algo aprendível?

Não são apenas as pré-concepções (do ponto de vista epistemológico) que influenciam em uma situação de aprendizagem; mas também as pré-valorações (do ponto de vista axiológico e ontológico). No final das contas, na relação entre realidade, linguagem (inclusive a científica) e pensamento, supomos que os obstáculos linguísticos revelam, na verdade, obstáculos epistemológicos, ontológicos e axiológicos. Obstáculos cujas transposições podem se concretizar na metodologia problematizadora freiriana. Metodologia que intenta trazer para a sala de aula o (nas palavras de Mattos) "conhecimento vital". Não como algo morto, mas como uma dinâmica "negociação intersubjetiva de significados".

Por tudo isso, Mattos nos alerta de forma veemente quanto à prática educacional que se esquece de falar da vida, que se abstém de discutir sobre as questões axiológicas e ontológicas com os estudantes. Ele (2010, p. 142) cita Camus ${ }^{36}$ :

Só há um problema filosófico verdadeiramente sério: é o suicídio. Julgar se a vida merece ou não ser vivida, é responder a uma questão fundamental da filosofia. O resto, se o mundo tem três dimensões, se o espírito tem doze categorias, vem depois.

Acreditamos que é partindo dessa concepção que poderemos compreender a frase tão temida pelos professores: "para que serve isso?". A essência dessa pergunta revela-nos muito mais sobre a relação do indivíduo que a proferiu com o conhecimento do que sobre a utilidade do conhecimento contestado. O que nos leva a crer que as escolhas ontológicas, axiológicas e epistemológicas devem ser realizadas com os educandos, e não para eles, e por meio da "negociação problematizadora" (MATTOS, 2010, p. 152).

No âmago dessas últimas considerações sobre a relação do sujeito com o saber, um trecho de um poema de Carlos Drummond de Andrade (1983, p. 128) revela nossas escolhas frente ao apontamento de Camus e abre-nos as portas para o próximo capítulo:

Pouco importa venha a velhice, que é a velhice?

Teus ombros suportam o mundo e ele não pesa mais que a mão de uma criança.

As guerras, as fomes, as discussões dentro dos edifícios provam apenas que a vida prossegue e nem todos se libertaram ainda.

Alguns, achando bárbaro o espetáculo,

\footnotetext{
${ }^{36}$ CAMUS, A. O Mito de Sisifu: um ensaio sobre o absurdo. Lisboa: Livros do Brasil, s. d. Original de 1943,
} p. 13. 
prefeririam (os delicados) morrer.

Chegou um tempo em que não adianta morrer.

Chegou um tempo em que a vida é uma ordem.

A vida apenas, sem mistificação. 


\title{
Capítulo V
}

\section{Ficção Científica: Um InSTRumento Pedagógico da EsPeranÇa}

\author{
$\boldsymbol{O U}$
}

\author{
'A Cidade e as Estrelas'
}

Quando a realidade era deprimente, os homens tentavam consolar-se com mitos.

Arthur C. Clarke, 1984, p. 136.

Callitrax sorriu, com certa tristeza.

- São muitas as lendas como essas, em parte verdadeiras, em parte falsas, e há outros paradoxos em nosso passado que ainda não foram solucionados. Esse problema, entretanto, compete mais ao psicólogo que ao historiador. Não se pode confiar nem mesmo nos registros do Computador Central, que mostram sinais claros de deturpação do passado mais remoto.

- Na Terra, apenas Diaspar e Lys sobreviveram ao período de decadência: Diaspar, graças à perfeição de suas máquinas; Lys, devido a seu isolamento parcial e aos inusitados poderes intelectuais de sua população. Mas ambas as culturas, mesmo quando conseguiram retornar a seu antigo nível, achavam-se distorcidas pelos temores e mitos que haviam herdado.

- Não há porque deixarmos que esses temores continuem a perseguir-nos. Não me cabe, como historiador, prever o futuro, mas apenas observar e interpretar o passado. A lição, porém, é bastante clara; temos vivido muito tempo sem contacto com a realidade, e agora chegou o momento de reconstruirmos nossas vidas.

Idem, p. 253.

Nos capítulos anteriores, argumentamos que a cultura pode nos manipular ou libertar. Vimos que um exame de suas diferentes linguagens revela mitos - instrumentos de coerção. E que é na própria linguagem que se desvela o caminho da emancipação.

Destarte, na práxis pedagógica, a linguagem não pode ser abstrata, mas deve falar dos problemas da realidade. Não deve se abster de abordar as questões existenciais dos habitantes de cada município, e nem deve impedi-los de alçar voos imaginativos pelo cosmos. Afinal, cidade e estrelas são palavras que ressoam nas vivências, nos desejos e nas angústias de cada sujeito; e, portanto, elas encontram sua realidade no próprio ser humano. E é no ser humano, na sua linguagem e na sua cultura, que reside a esperança.

É dela que falaremos neste capítulo, finalmente apresentando a ficção científica como um instrumento dessa perspectiva no que se refere à educação em ciências. 
Recordando minha vida colegial vejo quão pouco os mestres contribuíram para a formação do meu espírito. No entanto, a Júlio Verne todo um mundo de coisas eu devo! E a Robinson? Falaram-me à imaginação, despertaramme a curiosidade - e o resto se fez por si.

Júlio Verne levou-me a Humboldt e depois à geografia e às demais ciências físicas e sociais. Foi o aperitivo. Entreabriu-se as cortinas do mundo como coisa viva, pitoresca, composta de paisagens e dramas. De posse dessa visão, e esporeada pela imaginativa, a inteligência "compreendeu e quis saber". Que menino, após a leitura de Keraban, o cabeçudo, não corre espontaneamente a abrir um atlas para ver onde fica o Bósforo?

A inteligência só entra a funcionar com prazer, eficientemente, quando a imaginação lhe serve de guia.

A bagagem de Júlio Verne, amontoada na memória, faz nascer o desejo do estudo. Suportamos e compreendemos o abstrato só quando já existe material concreto na memória. Mas pegar de uma pobre criança e pô-la a decorar nomes de rios, cidades, golfos, marés, como se faz hoje, sem intermédio da imaginação, chega a ser criminoso. É no entanto o que se faz!... A arte abrindo caminho à ciência: quando compreenderão os professores que o segredo de tudo está aqui? (LOBATO apud ZANETIC, 2009, pp. 297:8).

Sucinta e bela essa leitura de mundo de Monteiro Lobato. Ainda mais porque, por ser leitura, provoca o diálogo. Convite aceito por Zanetic que a interpreta com base em sua cosmovisão. Se, por um lado, ele concorda com o otimismo que relaciona arte e ciência, por outro, denomina pessimista a imagem de professor que ela suscita inicialmente. Reiteremos, portanto, que a percepção de um problema não deve estagnar, pois traz em si o germe da oportunidade: a busca da solução.

Já apontamos anteriormente que um possível motivo para a incompreensão da física por parte dos estudantes é sua obsessiva descontextualização. Os conceitos e algoritmos são usualmente ensinados: destacados do contexto histórico no qual foram criados; distantes do contexto cultural no qual o aluno está inserido; e, desligados da visão de mundo na qual fazem sentido. História, epistemologia, cotidiano, experimentos... Muito é negligenciado. E, provavelmente, outras leituras de mundo encontrariam outras descontextualizações. Subtraem-se a complexidade e a densidade conceitual e filosófica do conhecimento e, nesse processo, roubam-se-lhe, também, os desafios, a beleza, a vivacidade, a vitalidade, as paisagens, os dramas...

Pior. Esse reducionismo restringe o ensino a uma linguagem matemática (que o jovem, em geral, não domina) e a definições mortas, coercitivas, adestradoras da imaginação. Compelindo e limitando a linguagem a domínios que o estudante ainda desconhece, tal prática afasta a esfera do julgamento para longe de sua compreensão ativa e responsiva. $\mathrm{O}$ aluno apenas identifica sinais. Como ele irá julgar uma linguagem que não entende? 
Por isso, mais importante do que a (re)contextualização nas visões de mundo veiculadas pela ficção científica, é a possibilidade que elas abrem, por serem um reflexo da realidade, para que o aluno se posicione, tome partido, julgue, critique, analise. O contexto, portanto, não deve ser neutro, não pode ser bege... E nem o aluno amarelo! A visão de mundo deve instigar, desafiar. Como diria Zanetic, deve dar sabor ao saber, gerar brilho nos olhos.

Física é cultura, dela se alimenta e com ela estabelece o diálogo necessário para formular juízos de valor sobre os fatos que envolvem a ciência e a sociedade. Pertence à cultura porque se expressa em uma linguagem que encontra seus significados nas complexas teias que os clássicos da literatura e da ciência teceram ao longo dos tempos (CANDOTTI, 2009, p. 17).

É aqui que a ficção científica ganha pontos: como contexto e pretexto. Não como panaceia salvacionista, mas como uma oportunidade desafiadora. Cada conto, cada filme, cada autor, tudo possui uma visão de mundo ${ }^{37}$. Desfiá-la pode ser muito intrigante... e pode ser muito chato. A atuação do educador nesse momento é crucial: deve incitar o movimento. Deve ser provocação. Assistir e debater 2001 - Uma odisséia no espaço pode ser uma vivência maravilhosa ou maçante, dependendo da postura axiológica, da escolha ontológica, da curiosidade epistemológica inicial dos envolvidos.

A força pedagógica da ficção científica não se restringe ao prazer eventualmente promovido por suas narrativas, mas reside justamente na possibilidade de ser utilizada como um meio de compreender as angústias vitais que perpassam a sociedade na qual ela foi criada. Por exemplo: qual a relação entre a modernização e a degradação ambiental? Qual a relação entre o poder e o conhecimento? Questões recorrentes na ficção científica e que podem levar a um engajamento do educando pela própria aprendizagem ao ressoar em decisões que dizem respeito a sua vida.

Esclarecendo: julgar o conhecimento científico não é o mesmo que julgar os personagens, as narrativas, os dramas, etc. Na educação científica, normalmente se espera que o aprendiz se torne crítico justamente em relação aos conceitos científicos. É nesse ponto que defendemos uma mudança de postura pedagógica. Os indivíduos devem ser capazes de julgar a relação entre o conhecimento e sua realidade, entre a ciência e sua sociedade. Um ensino bancário, apegado a mudanças conceituais internalistas, está fadado a ser usufruído principalmente por jovens que possuem um gosto prévio pela ciência, excluindo os demais da

\footnotetext{
${ }^{37}$ Náder (2009, p. 126) critica a visão utilitarista que se atribui ao contexto nos trabalhos que o identificam com a necessidade de fazer o conhecimento parecer evidentemente prático no cotidiano imediato. Laranjeiras (2009, pp. 193:210) também critica um utilitarismo semelhante em relação à história da ciência. Martins (2009, p. 276) aponta o uso descriticizado do termo contextualizar. Nós também acreditamos que a contextualização não deve ser encarada como uma forma de seduzir, capturar o aprendiz; mas que ela deve, ao contrário, ser palco de uma problematização da realidade, permitindo nossa emancipação (de educandos e educadores).
} 
emancipação por ela possibilitada. A temida frase: "pra que serve isso?" é um indício de que o conhecimento foi desmantelado, afastado da importância vital que conduziu a sua elaboração. O ensino de física deve começar pela discussão de visões de mundo, em especial a relação entre a ciência e a tecnologia e essas visões - e não por especificidades descontextualizadas.

Ensinar a ciência como neutra, isolada do mundo, é um crime. Daí a necessidade de trabalhar sua interação com outros produtos da cultura. Nesse sentido, a catarse com uma narrativa pode levar o educando a reconhecer determinado conhecimento como algo vital, transpondo, dessa forma, os obstáculos axiológicos e ontológicos. Superados esses obstáculos, as questões epistemológicas serão encaradas como desafio real, e não como banalidades a serem memorizadas, decoradas para passar no vestibular. Isto é, o prazer que a ficção científica pode proporcionar não se restringe à distração imediata, ao encantamento com a magia de um filme ou conto (e isso, por si só, já valeria muito - afinal, nem a vida nem a escola podem ser apenas um acúmulo de preocupações), mas também no prazer de debulhar o mundo que nos aflige e nos encanta.

O jovem conhece, mesmo que parcialmente (somos todos assim), o contexto e o pretexto de uma enunciação. Sofre os efeitos morais de sua manifestação. Julga o valor que o enunciado carrega. A catarse pode catalisar a percepção do conhecimento como algo vital, que merece e precisa ser aprendido para possibilitar autonomia frente às opções.

Contudo, como destacamos nos capítulos anteriores, a aprendizagem não depende somente do engajamento pela própria educação, mas também do distanciamento, da decodificação do mundo, desvelando algumas de suas características que antes impunham-se como míticas, místicas, mágicas. Nesse movimento mental, nessa transgressão, o aprendiz passa da contribuição inicial para uma outra perspectiva da cultura, elaborada por si mesmo ou por outros autores-atores que eventualmente auxiliarem na interpretação dos enigmas do cosmos.

Nessa negociação intersubjetiva dos significados, uma preocupação do docente seria: quais os mitos culturais que herdamos (educandos e educadores)? Anteriormente, falamos de alguns: invulnerabilidade da realidade; impotência dos indivíduos; hierarquia entre culturas; etc. E mesmo as contribuições iniciais dos estudantes no que se refere à ciência, se encaradas como cultura alternativa a ser qualitativamente comparada, sistematizada, possivelmente incrementada, aperfeiçoada, podem ser consideradas mitologia a ser problematizada. Logo, especificamente para a física, temos outros exemplos: gravidade; massa; método científico; etc. - concepções modernas ou ultrapassadas que, encaradas dialogicamente (tudo é problematizável!), podem estimular o raciocínio, a compreensão, a criatividade, a subversão. 
Como vimos na metodologia freiriana, o processo de descoberta desses potencialmente inquietantes mitos culturais (investigação temática) revela a ação pedagógica necessária em cada praça espaço-temporal. Posteriormente, codificam-se os mitos. "A codificação faz, portanto, a mediação entre o contexto concreto e o teórico" (DELIZOICOV, 1982, p. 26).

A questão é saber se esses e outros mitos realmente perpassam a ficção científica, pois é precisamente isso que responderá uma pergunta crucial: utilizar a ficção científica não caracteriza uma invasão cultural? Se a obra escolhida não refletir as situações-limite que afligem a população de uma determinada região, seu uso de fato denuncia a invasão; porém, se ela trouxer em si elementos que abordam direta ou indiretamente essas situações, então a escolha da equipe pedagógica não será uma invasão, mas um tema dobradiça ou gerador vital para a emancipação daquele grupo de pessoas.

Trabalharemos, agora, os momentos da metodologia freiriana - interpretando-os em um modo mais restrito e adequado aos propósitos deste trabalho. Isso para que o uso da ficção científica não se faça ao acaso, despropositadamente, mas de uma forma planejada, organizada. Afinal, a mera identificação dos mitos não garante sua compreensão. A simples negação impensada dos mesmos também não é a postura almejada, pois acorrenta o indivíduo ao que ele já é, e impede-o de saber e ser mais.

Lembremos que a dinâmica do processo é: investigação dos mitos $\rightarrow$ codificação dos mitos $\rightarrow$ problematização dos códigos $\rightarrow$ aprofundamento da problematização (estudo das unidades de aprendizagem) $\rightarrow$ atuação no mundo. Delizoicov (et al., 2007, p. 166) sistematiza tal sequência em três momentos pedagógicos: estudo da realidade, organização do conhecimento e aplicação do conhecimento. Sigamos tal rearranjo.

\section{V.1 - Estudo da Realidade: A RelaÇão entre A FicÇão CientífiCa e SEU Contexto}

A investigação temática é um trabalho muito específico de cada região. Qual poderia ser sua relação com a ficção científica? Se pensarmos que as situações-limite, as tensões sociais, econômicas, políticas, etc., repercutem na produção cultural, é de se esperar que a ficção científica ecoe tais influências. Se uma obra carrega em si alguma das situações-limite reveladas por um grupo de educandos, ela pode ser usada como código a ser problematizado. Um filme, um conto, um episódio de seriado, etc., tudo isso pode ser usado como canal de comunicação (simplesmente visual, auditivo, ou um misto de visual e auditivo). Em vez de se criar a codificação da realidade, utiliza-se a ficção científica como código pronto. 
Nada impede, também, a equipe interdisciplinar de criar uma narrativa de ficção científica para ser analisada pelo círculo de cultura. Cremos que a discussão posterior auxiliará a equipe a atentar aos mitos perpetuados por sua própria produção.

Antes de buscarmos estudos mais profundos sobre os ecos daquelas influências, existe algo nos incomodando, e que gostaríamos de abordar aqui. Recordemos: Freire indica que o código deve ser sucinto, curto - o que não é o caso se pensarmos em filmes, contos, romances... Sua preocupação é legítima. Ela intenta não transformar o processo pedagógico em difícil adivinhação meramente intelectual. Porém, lembremos, a proposta freiriana é um guia, e não uma lei inapelável. A equipe pode variar, experimentar. Para nós, é exatamente a longa duração da narrativa que possibilita a imersão na história, permitindo uma identificação com as personagens e a catarse com as situações apresentadas. Se isso ocorrer, é sinal de que a decodificação da obra poderá surtir efeito em sua problematização.

Que fique claro, portanto, que a imersão nas narrativas é de um tipo diferente das “criptografias" concisas sugeridas por Freire, usualmente mais imediatas (o que não quer dizer banais) em relação às situações vivenciais dos educandos. Cabe ao educador instigar os educandos a decriptar o "código-narrativa" para descobrir, nesse primeiro momento, suas opiniões e suas formas de pensar (revelados sintática e semanticamente em seus enunciados).

Devemos, contudo, diferenciar outro ponto. Tanto um código simbólico criado deliberadamente para o uso pedagógico quanto um código-narrativa carregam mitos inconscientes, despercebidos. Todos estamos fadados a propagar paradigmas sobre os quais não refletimos. Daí a importância do diálogo, seja com outras pessoas, seja com livros, filmes, etc. Daí a importância, também, de não considerarmos a educação como a aprendizagem de conhecimentos fixos, reveladores de uma verdade eterna sobre um mundo estático; mas como a compreensão de uma visão contextualizada de um mundo mutante. O mundo não deve ser encarado como uma foto, mas como um filme. O mesmo vale para o conhecimento.

É necessário perceber, além disso, que interpretar os símbolos propositais de um código é diferente de reconhecer os fantasmas inconsiderados que ele dissemina. Em uma relação entre homens e robôs, por exemplo, existe a interpretação literal com anseios e receios em relação ao eventual desenvolvimento da inteligência artificial. Por outro lado, como veremos, essa relação pode representar alegoricamente a relação entre os senhores coloniais e os escravos. Ambos os casos exigem interpretação. Em um caso, busca-se compreender qual o pretexto deliberado. No outro, quais os ignotos preconceitos de um contexto cultural difundidos involuntariamente (ou não) pela obra. A metodologia para enfrentar ambos os casos, contudo, é fundada na mesma premissa: é o diálogo problematizador que nos permite 
entrever os valores impensados e as metáforas intencionais em cada cosmovisão. O que realmente importa, pedagogicamente falando, é utilizar códigos que carreguem uma perspectiva de mundo referente às situações-limite, às ideologias que governam nossas vidas, para delas nos conscientizarmos e tentarmos nos emancipar.

Um bom caminho para descobrir se a narrativa escolhida representa questões existenciais que incomodam, provocam os educandos, é incitá-los a expor suas sensações e seus sentimentos, suas expectativas e decepções, os êxtases e os sustos que acometeram cada um deles durante a história. Os sentimentos de simpatia ou antipatia que percorrerem a alma de cada jovem-intérprete representam oportunidades de problematizar seus julgamentos sobre as relações homens-homens e homens-mundo.

Em suma, a longa duração de contos ou filmes impede o uso dessas obras? Não. Tal fato pode dificultar o reconhecimento das situações vivenciais dos educandos, mas se tal dificuldade for enfrentada como desafio, como enigma a ser superado, e se a metáfora das obras não extrapolar em demasia a capacidade de abstração dos educandos e suas zonas de desenvolvimento proximal, isso não deve ser encarado como uma barreira inquebrantável.

Exatamente por isso todas as problematizações (sejam de obras lineares ou intrincadas) podem ser acompanhadas por codificações auxiliares. Para tanto, pode-se, por exemplo, imprimir, escrever na lousa ou projetar cenas com trechos ou falas marcantes da narrativa, que evidenciem as situações-limite e vitais que justificam sua escolha para determinado grupo.

Como isso não parece implicar dificuldades intransponíveis, podemos retornar à questão do momento: a ficção científica retrata problemas sociais, mitos culturais, situaçõeslimite, diferentes ideologias do mundo atual?

Eis que, ao buscar amparo para responder essa pergunta, encontramos um livro que a enfrenta diretamente, obra imprescindível tanto para pesquisadores quanto para educadores que pretendem trabalhar com a ficção científica na escola: Ficção científica brasileira: mitos culturais e nacionalidade no país do futuro, de M. Elizabeth Ginway ${ }^{38}$. Ela traça um histórico da ficção científica nacional de 1960 até 2001, buscando eventos e mitos culturais que influenciaram as obras, encarando-as como "atos socialmente simbólicos" do "inconsciente político" de nossa cultura (GINWAY, 2005, p. 31).

Saudado como um paraíso tropical, mais tarde como um gigante adormecido, e finalmente como o país do futuro, pleno de possibilidades

\footnotetext{
${ }^{38}$ Ginway graduou-se pelo Smith College e, de 1982 a 1983, recebeu a Bolsa Fullbright para pesquisa no Brasil. Com doutorado pela Vanderbilt University, lecionou na University of Georgia e na Emory University. Atualmente é professora de Português e Literatura Brasileira no Departamento de Estudos de Espanhol e Português da Universidade da Flórida, em Gainesville. É reconhecida pesquisadora da ficção científica brasileira.
} 
latentes, o Brasil tem sido apontado por cronistas e historiadores desde sua descoberta pelos portugueses em 1500, como estando destinado à grandeza. Durante a segunda metade do século XX, o Brasil lutou para modernizar-se, em uma tentativa de realizar esse potencial há muito anunciado. A ficção científica, por causa de suas ligações com a ciência e a tecnologia, é o veículo ideal para o exame da percepção e do impacto cultural do processo de modernização no Brasil (GINWAY, 2005, p. 13).

Além de destrinchar a metamorfose que temos enfrentado, Ginway diferencia a produção brasileira do cânone anglo-americano, evidenciando a divergência do impacto cultural da ciência e da tecnologia no Brasil se comparado aos países do primeiro mundo. Informações muito ricas para o docente que pretende utilizar obras nacionais ou estrangeiras. Ainda que sua análise se resuma à literatura, acreditamos que também fornece subsídios para a compreensão da produção cinematográfica e televisiva.

Como as políticas de industrialização e desenvolvimento econômico da ditadura militar (1964-1985) são um marco na história da modernização do país, Ginway divide seu estudo em três períodos: anterior, contemporâneo e posterior à ditadura. Faremos aqui um resumo de alguns aspectos de sua análise, tentando captar a essência dos mitos enumerados, citando algumas obras que ela aponta como exemplares de tais unidades epocais. Interessante notar que ela acabará esboçando um histórico dos mitos nacionais das últimas décadas, o que auxilia na compreensão da dinâmica de nossa sociedade - percepção de extrema importância para uma práxis pedagógica viva. Acompanhemo-la.

\section{V.1.1 - BREVE Histórico da FicÇão Científica NACIONAL (SEgUNdo M. GiNWAY)}

\section{V.1.1.1 - O PRIMEIRo PERÍODo (APROXIMADAMENTE 1960-1970)}

Como introdução, podemos lembrar alguns mitos anteriores a esse período e que acabaram afetando-o: o Brasil como um paraíso tropical, como uma democracia racial, com potencial para a grandeza como nação, e com um povo sensual, dócil, cordial e hospitaleiro; todos eles, em certo sentido, buscando guarnecer e fortalecer o senso de identidade nacional (GINWAY, 2005, pp. 16:7).

Pensando nesses mitos de longa data, percebemos que a terra fertilíssima, a beleza natural e a harmonia racial são exaltadas - exemplifica Ginway (2005, p. 18) - em Iracema (1865), de José de Alencar ${ }^{39}$. O filho da índia com o português - Iracema falece dias após o parto - é um símbolo do nascimento do povo brasileiro, indicando a miscigenação como uma

\footnotetext{
${ }^{39}$ ALENCAR, José de. Iracema. 1865. Reedição, São Paulo: Ática, 1982.
} 
alegoria para a consolidação nacional. O equívoco dessa perspectiva é que a miscigenação não se deu predominantemente entre portugueses e índios - uma vez que estes se revoltaram ou foram dizimados pelas doenças -, mas principalmente entre aqueles e os africanos, mistura que teve impacto decisivo em nossa cultura. A simbiose entre senhores e escravos originou outros mitos, dentre eles o do patriarca branco benevolente, cujo paternalismo revela a naturalização de uma hierarquia e o machismo da sociedade brasileira (idem, p. 19).

Voltemos ao período em questão, quando o avanço econômico se torna a ordem do dia e a euforia com a modernização ganha força política.

A pressão para o desenvolvimento figura com proeminência no slogan da campanha presidencial de Juscelino Kubitschek em 1955, "Cinqüenta Anos de Progresso em Cinco", uma imagem que ele buscou concretizar com seu projeto predileto, o da nova capital Brasília, que, ele esperava, iria oferecer uma fonte de otimismo, realização e confiança aos brasileiros. Os prospectos utópicos dessa nova capital incorporavam a retórica da modernização e se tornaram um símbolo altamente visível do desejo do Brasil de romper com seu passado rural, colonial e baseado na agricultura. Esta imagem da cidade como um lugar mítico de riquezas, possibilidades utópicas e realizações incorpora o mito moderno do espaço urbano (GINWAY, 2005, p. 22).

Vide a intensa migração do campo para as cidades, e das regiões desoladas para as megalópoles; que acabam se tornando o centro da cultura e da política, sorvendo boa parte da renda nacional. Nesse contexto, os persistentes mitos herdados da sociedade e dos períodos literários anteriores chocam-se com os valores inerentes ao modo de vida importado. Tornamse, assim, imbuídos de um angustiante sentimento de perda ocasionado pelo processo acelerado de industrialização e urbanização. Teme-se a ameaça de asfixia das tradições e dos "virtuosos costumes patriarcais". A ficção científica nacional desse período caracteriza-se por fachadas futuristas, mas tendências humanistas e uma postura receosa frente à modernização (GINWAY, 2005, p. 37). Em outras palavras, existe esperança no futuro, mas desconfia-se da ciência e da tecnologia, pois se desconfia do "poder da razão em controlar os excessos das emoções humanas" (idem, p. 39). Em uma sociedade marcada por uma rígida divisão de classe, a tecnologia agrava a situação, ao invés de solucioná-la.

Essa visão da tecnologia é resultado de vários fatores culturais e históricos. Sendo um país de Terceiro Mundo, o Brasil tem freqüentemente dependido de tecnologia importada, sobre a qual tem pouco controle. A tecnologia é também vista como tendo um efeito negativo nas relações sociais, destruindo o contato pessoal que é um fator central na cultura brasileira. Finalmente, os escritores brasileiros começaram a publicar no ápice da Guerra Fria ${ }^{40}$, em uma época de considerável suspeita da tecnologia e de suas implicações para a sociedade e a paz mundial (GINWAY, 2005, p. 39).

\footnotetext{
${ }^{40}$ Ginway não ignora que existe uma produção anterior a esse período e cita o estudo de Causo (2003).
} 
Por contraste, verificamos que essa postura é bem diferente daquela do início da produção estadunidense. As revistas pulp, editadas por Hugo Gernsback nas décadas de 192030 em um contexto de modernização distinto do brasileiro, eram dominadas por um otimismo ingênuo frente à ciência e à tecnologia. É distinta também da fase seguinte: a Era de Ouro dirigida pelo editor John W. Campbell Jr. (décadas de 1930-40, com autores do calibre de Isaac Asimov, James Blish, Frederik Pohl, etc.), cujas obras analisam com mais profundidade as implicações sociais da modernização, mas sem perder o caráter favorável a suas contribuições. O progresso social seria consequência da vitória da razão e da ciência sobre a emotividade, o caos e a irracionalidade (GINWAY, 2005, pp. 14 e 38).

Publicando pela Edições GRD e pela EdArt, a primeira leva de escritores de ficção científica nacional (André Carneiro, Fausto Cunha, Dinah de S. Queiroz, Rubens T. Scavone e Jeronymo Monteiro) em geral utiliza ícones ${ }^{41}$ da produção anglo-americana, mas contesta aqueles paradigmas da ficção norte-americana, afirmando temas e problemas particularmente brasileiros nesse processo de "re-colonização" tecnológica (GINWAY, 2005, p. 32). Ao invés de endossar a tecnologia e o desenvolvimento, as obras desses autores são mais céticas, e usualmente falam da Guerra Fria, da alienação individual e das reações subjetivas à modernização (idem, p. 32).

A New Wave anglo-americana (1964-1972: Brian Aldiss, J. G. Ballard, Robert Silverberg, etc.) também se caracteriza por uma postura antitecnológica e por uma abordagem mais psicológica. Semelhanças que, segundo Ginway (2005, p. 40), são apenas coincidência, pois as evoluções históricas dos mitos culturais e gêneros literários no Brasil e na Inglaterra/Estados Unidos são bem distintas. Em resumo,

Enquanto a ficção científica americana geralmente abraça a tecnologia e a mudança, mas teme rebeliões ou invasões por robôs e alienígenas, a ficção científica brasileira tende a rejeitar a tecnologia, mas abraça os robôs e acha os alienígenas como sendo em geral indiferentes ou exóticos. Estas diferenças, eu acredito, refletem a experiência colonial e neo-colonial do Brasil, seu legado como uma sociedade de antigos escravos, e sua população diversa, racialmente mestiça (GINWAY, 2005, p. 41).

Ginway $\left(2005\right.$, p. 43) aponta que em $O$ Velho (1965) de Clóvis Garcia ${ }^{42}$, um idoso economiza dinheiro para comprar um robô que lhe faça companhia. Citando essa e outras histórias, ela mostra como o robô é uma imagem cultural ligada à escravidão. No Brasil, eles

\footnotetext{
${ }^{41}$ Ginway organiza sua discussão da ficção científica em torno dos ícones estudados por G. Wolfe (WOLFE, Gary K. The Known and the Unknown: The Iconography of Science Fiction. Kent, Ohio: Kent State University Press, 1979). Ícones que, segundo ele, quando utilizados, são bons indicadores da filiação da obra ao gênero ficção científica: espaçonaves, robôs, alienígenas...

${ }^{42}$ GARCIA, Clóvis. O Velho. In: Além do Tempo e do Espaço: 13 Contos de Ciência Ficção. São Paulo: EdArt, 1965.
} 
são acolhidos de forma paternalista, assumindo - e aceitando devota e passivamente - funções domésticas. Ou seja, existe uma relação íntima, afetuosa, familiar, mas o robô-serviçal é considerado inferior, mera propriedade - é o mito da escravidão benevolente. Antropomorfizada, a tecnologia não resolve as questões raciais.

Por outro lado, nos Estados Unidos, os robôs normalmente são máquinas frias, verdadeiros símbolos da tecnologia, meros substitutos insensíveis das funções humanas - o que gera desconfiança e medo da rebelião. Um reflexo desse receio são as famosas leis da robótica de Isaac Asimov. Matrix perpetua esse mito norte-americano. Ginway (2005, p. 45), citando Carl Degler, afirma que, no Brasil, o escravo podia até ser temido, mas o homem negro liberto não o era; enquanto, nos Estados Unidos, tanto os escravos como os negros alforriados eram temidos. Porém, esse mito brasileiro da democracia racial - inconcebível nos Estados Unidos - não sobrevive a critérios socioeconômicos. A aparente harmonia racial oculta a intolerância social, a inflexibilidade e a própria discriminação - escamoteadas em questões biológicas (“quem é capaz, ascende...”) (idem, pp. 19:21).

Já os alienígenas da ficção científica nacional simbolizam a "esperança de reconciliação de questões de raça dentro do Brasil e o medo de subjugação, seja por estrangeiros ou por forças incontroláveis da natureza" (GINWAY, 2005, p. 54). Em Ma-Hôre de Rachel de Queiroz $^{43}$, um alienígena “pequeno e amigável” é capturado por astronautas que pretendem exibi-lo em um zoológico da Terra. Após descobrirem que ele é inteligente, ensinam-lhe sua língua. Ele fala de sua cultura, com tendência para a arte, e afirma que as únicas armas que sua raça possui destinam-se à caça, e que o fogo (símbolo do conhecimento no mito grego de Prometeu) é abominado. No fim, o alienígena aprende a usar a tecnologia da nave em que estava aprisionado, valendo-se dela para envenenar seus raptores. Simbolicamente, ele usa a tecnologia alheia contra os pretensos colonizadores, que subestimaram sua cultura. Esse final assinala o desejo, a fantasia da colonização reversa (GINWAY, 2005, p. 60).

Outra abordagem para os extraterrestres que aparece na produção nacional retrata-os como "indiferentes à cultura humana (i.e., brasileira). Isso difere da típica história norteamericana de alienígena, na qual os alienígenas vêm para conquistar, ou para impor a paz" (GINWAY, 2005, p. 61). Em Invasão (1966) de André Carneiro ${ }^{44}$, alienígenas pousam na selva amazônica, permanecendo indiferentes aos militares e curiosos que se estabelecem ao redor. Um sargento venezuelano atira em um alienígena desarmado, que foge para a nave e, nesse ínterim, deixa cair uma misteriosa caixa preta. Esta continua indecifrável até o final da

\footnotetext{
${ }^{43}$ QUEIROZ, Rachel de. Ma-Hôre. In: Histórias do Acontecerá. Rio de Janeiro: Edições GRD, 1961.

${ }^{44}$ CARNEIRO, André. Invasão. In: O homem que adivinhava. São Paulo; EdArt, 1966.
} 
história, mesmo com todas as investigações realizadas. Um genuíno anticlímax. Nas histórias nacionais, a ciência e a tecnologia alheias são forças incompreensíveis, inúteis para resolver crises locais, e não há uma troca significativa de conhecimento entre as culturas. Isso de fato parece ocorrer nas interações do Brasil com os estrangeiros, que usualmente querem apenas tirar proveito dos recursos naturais do país, e não dos recursos humanos, mostrando-se desinteressados em relação a nossa cultura e ao nosso futuro - prática que remonta à nossa colonização (GINWAY, 2005, pp. 62:9).

Outro ícone, a nave espacial, que nas obras americanas, via de regra, era usada para superar o desconhecido e avançar para um futuro promissor, aparece na produção brasileira como um veículo nostálgico para retroceder ao passado (GINWAY, 2005, p. 80). As relações sociais que se estabelecem em seu interior são um reflexo da sociedade da qual a espaçonave provém, permitindo uma boa análise de sua cultura.

Diário da Nave Perdida (1963), de André Carneiro ${ }^{45}$, é a história de um narrador homem e sua assistente que se perdem no espaço quando a nave sofre um acidente. Com a tripulação técnica morta, e sem conseguir reparar os danos, aos poucos seus suprimentos vão se esgotando. Dentre eles, uma droga utilizada para inibir as emoções. Eventualmente, quando ela acaba, seus sentimentos emergem - junto com os estereótipos sexuais. Esse renascimento dos aspectos humanos é o contrário do que costuma ocorrer nas obras de Clifford D. Simak, Edmund Cooper e Philip J. Farmer, em que a ciência floresce contra a ignorância (GINWAY, 2005, pp. 74:5). No fim da história, após o regresso do casal cosmonauta à civilização, cada um escolhe um caminho. A mulher opta pela "existência altamente regulada" da Terra. O homem prefere se dirigir a Marte, para junto de uma civilização mais espiritual e ecológica, contemplativa, equilibrada com a natureza, de certa forma resgatando sua humanidade.

Quase paradoxalmente, o ícone da cidade futurista é retratado positivamente na ficção científica brasileira, e negativamente na norte-americana. O romance de Jerônymo Monteiro $^{46}$, Os Visitantes do Espaço (1963), apresenta dois ambientes hostis: os planaltos desérticos, onde uma cidade parecida com Brasília está sendo planejada; e, a enigmática Amazônia, onde pousam naves extraterrestres. O contraste entre a tecnologia das espaçonaves e os ambientes incivilizados evidencia as desigualdades entre o mundo desenvolvido e o subdesenvolvido (GINWAY, 2005, p. 66). A organização da "cidade exemplar" é uma panaceia contra os males sociais:

\footnotetext{
${ }^{45}$ CARNEIRO, André. Diário da nave perdida. In: Diário da nave perdida. São Paulo; EdArt, 1963.

${ }^{46}$ MONTEIRO, Jerônymo. Os Visitantes do Espaço. São Paulo: EdArt, 1963.
} 
Acreditava no futuro, acreditava no Brasil, acreditava sobretudo naquelas imensas e ricas regiões do Brasil Central, onde surgiu o Mundo Novo. Planejava erguer em suas terras uma cidade modelo onde todos fossem felizes, vivessem na fartura e com amor. Uma cidade que se estendesse por quilômetros de ruas largas e ajardinadas com casas térreas, sem arranhacéus, sem fumaça, sem explosões, sem ruídos (MONTEIRO apud GINWAY, 2005, p. 80).

Mesmo nesses casos, contudo, a ciência continua tendo sua validade questionada; e, normalmente, é a interação, a solidariedade e a compreensão da interdependência que redimem e humanizam as cidades e os homens.

Em contrapartida, a cultura norte-americana assenta-se sobre o paradigma da superioridade da natureza, da vida selvagem e do mito do Oeste - uma fuga da prisão dos contratos sociais e da repressão da cidade à liberdade individual. Em sua ficção científica, o ambiente selvagem e desconhecido aparece no mito da fronteira final: a exploração do espaço exterior (GINWAY, 2005, pp. 22:3). Um exemplo recente disso pode ser visto em Battlestar Galáctica, um aclamado seriado estadunidense. Após anos vagando pelo espaço exterior em busca de um planeta habitável, a frota espacial, no episódio final, realiza seu mito do Oeste ao encontrar uma Terra verdejante, exuberante. A tripulação opta por destruir as espaçonaves e a tecnologia (enviadas em direção ao Sol) para voltar a viver uma vida primitiva. Para quem gosta de clássicos, basta lembrar do fim de Blade Runner de Ridley Scott, onde os protagonistas se dirigem ao campo em uma cena muito contrastante com a cidade soturna onde a trama se passava até então.

Um último assunto recorrente desse período é o ícone da terra devastada principalmente por conta da iminência de um holocausto nuclear. Usualmente, as obras dessa época possuem uma tendência didática e antibélica. A produção nacional, em especial, é recheada de alusões bíblicas, e deixa entrever certa sensação de desamparo e pessimismo além da impotência do Brasil, país sem voz nas decisões concernentes às bombas e à autodestruição da humanidade (GINWAY, 2005, pp. 87:9).

Com o fim da coleção do editor Gumercindo Rocha Dorea (as edições GRD), os escritores desviam-se do gênero, encerrando esse período. Final marcado, também, pela morte de Jeronymo Monteiro em 1970, um grande divulgador do gênero.

\section{V.1.1.2 - O SEGUNDO PERÍODO (CERCA DE 1970-1980)}

Consistiu na produção do período de governo ditatorial no Brasil, quando as políticas de modernização e desenvolvimento econômico se intensificaram, impactando a produção 
cultural por conta das repercussões sociais e morais desse processo: o agravamento da injustiça social, o autoritarismo, a repressão violenta, a censura e a perda de liberdades civis (GINWAY, 2005, p. 24).

O Brasil teve um dos regimes militares mais prolongados da história latinoamericana recente, e o seu sucesso deveu-se não apenas ao seu foco tecnocrático, mas também por sua habilidade em capitalizar o senso de destino do Brasil. A despeito dos planos ambiciosos dos militares de transformar e modernizar o país inteiro, o Brasil permanece dividido por diferenças raciais, geográficas, econômicas e, de acordo com o Banco Mundial, tem a pior distribuição de renda do mundo (GINWAY, 2005, pp. 24:5, grifo nosso).

Referindo-se a essa situação político-social, a ficção científica brasileira re-emerge, agora com ficções distópicas. Fazenda Modelo de Chico Buarque é um exemplo nacional de uma obra no estilo dos clássicos Admirável Mundo Novo, de A. Huxley, e A revolução dos Bichos e 1984, de G. Orwell.

Ginway (2005, p. 33) cita A. Lewis, que afirma ser a metáfora da máquina:

...não um grande dispositivo mecânico literal, mas um dispositivo político figurativo. É a sociedade planificada, levada à sua conclusão lógica, baseada na visão mecanicista da humanidade, e no conceito-colméia de fazer caberem os indivíduos em seus nichos apropriados.

Sua mecânica faz uso da tecnologia e da ciência para o controle social e político. A atmosfera satírica auxilia o leitor a entrever quais são as práticas sociopolíticas criticadas pela distopia. E assim como as distopias, as utopias também representam uma sociedade organizada, mas com uma postura otimista frente à racionalidade. Ginway, mencionando Northrop Frye ${ }^{47}$, indica que, nas utopias, o conhecimento é utilizado para controlar a natureza, enquanto que, nas distopias, é usado também para controlar a mente dos homens. Cuartas (2007, p. 89) afirma que a debilidade dessas utopias reside no fato de elas postularem uma sociedade mais ou menos estável em um meio estável.

Os escritores nacionais fazem uso dessas sociedades metafóricas para criticar a crueldade da repressão militar e a política de modernização; usualmente retratando uma rebelião coletiva ou individual contra o sistema. Procedendo dessa forma, eles acabam retomando os mitos de identidade brasileira, saudosos do passado, da natureza, do humanismo. Retratando desastres ambientais e a decadência na qualidade de vida, criticam uma elite moralmente falida. Esses valores, unidos no mito da brasilidade, são evocados

\footnotetext{
${ }^{47}$ FRYE, Northrop. Varieties of Literary Utopias. In: Utopias and Utopian Thought. Editado por Frank E. Manuel. Boston: Houghton Mifflin, 1966.
} 
como contraponto aos valores do regime, em que a identidade brasileira parecia se perder frente aos ditames do Estado. Porém:

Flora Süssekind ${ }^{48}$ acredita que, a despeito das boas intenções de seus autores, muitas dessas obras inconscientemente reforçam o projeto nacionalista dos militares, ao recorrerem a uma representação alegórica, e portanto limitada, do Brasil como nação. Ela prossegue afirmando que mesmo quando o retrato feito por eles do regime era desfavorável, os autores contribuíram, ainda que não intencionalmente, para uma literatura que representava as dores de parto da construção do país Brasil, um projeto que endossava o ponto de vista dos militares. Um outro perigo dessas obras reside em seu uso não-crítico de mitos nacionais da identidade brasileira, que tendem a perpetuar estereótipos idealizados do Brasil, ao invés de tentarem oferecer uma visão complexa de uma sociedade lutando com os problemas de um desenvolvimento tardio (GINWAY, 2005, pp. 95:6).

As obras de Herberto Sales, Mauro Chaves, Maria Alice Barroso e Ruth Bueno caracterizam-se principalmente pelo controle da natureza, das mulheres e da sexualidade. Para analisá-las, Ginway utiliza o ecofeminismo e a ecocrítica ${ }^{49}$, tentando desmontar os mitos da terra fértil e do povo sensual. Ou seja, ela tenta explicar e transpor os preconceitos que olham a mulher, o negro e o meio-ambiente como o outro sobre o qual atua o homem (GINWAY, 2005, pp. 33:4).

A experiência da colonização, especialmente como ela tem sido explicada por meio das ferramentas críticas do ecofeminismo, ajuda a explicar a rejeição da tecnologia que caracteriza a ficção científica brasileira. No seu Feminism and the Mastery of Nature (1993), Val Plumwood descreve como a filosofia ocidental, iniciando com Platão, criou um dualismo que coloca a razão humana em um plano superior em relação à natureza, que é concebida como disforme e caótica. Subsequientemente, o pensamento cartesiano declarou a esfera natural não-humana como sendo disponível para o uso e a dominação, levando Locke a concebê-la como propriedade. Assim, a natureza se torna meramente instrumental, i.e., uma ferramenta para o uso exclusivo do mestre humano. Dada a estrutura da sociedade patriarcal ocidental, não é surpreendente que essa dualidade tenha levado a uma oposição entre o mundo superior, supostamente razoável, dominado pelos homens, e o mundo inferior, natural, dominado pelo Outro, isto é, as mulheres e as minorias raciais, que, como componentes do mundo natural, seriam também reduzidas a mera propriedade ou instrumento de dominação masculina (GINWAY, 2005, p.41).

${ }^{48}$ SÜSSEKIND, Flora. Polêmicas, Retratos e Diários: Reflexos Parciais sobre a Literatura e a Vida Cultural no Brasil pós-1964". In: Fascismo y experiencia literária. Minneapolis: Institute for the Studies of Ideologies and Literature, 1985.

${ }^{49}$ A obra que embasa esse ponto de vista é The Lay of the Land de Annette Kolodny. Ginway (2005, p. 96) utiliza ainda os estudos da crítica brasileira Regina Zilberman, que analisa criticamente a metáfora da terra como mulher ou sujeito colonizado (explorado) na literatura nacional. 
Em outras palavras, negros e mulheres são associados à natureza e à terra, e a análise do papel destas na literatura permite entrever os mitos referentes àqueles ${ }^{50}$. Usualmente, a terra é violada e a natureza silenciada. Revelando que, no fim das contas, o outro é subjugado em relacionamentos hierárquicos tradicionais. Essa crítica permite visualizar os limites das distopias brasileiras. Vejamos alguns exemplos.

O protesto engendrado em Fazenda Modelo ${ }^{51}$ (1974) direciona-se para as questões da regulação da sexualidade e o controle populacional. A alegoria representa o povo brasileiro como um rebanho. De um lado, o gado de elite; do outro, o gado classe-trabalhadora, todos submetidos às experiências políticas da modernização. $O$ primeiro grupo é submetido a condições sanitárias controladas, dietas artificiais e à cópula minuciosamente regulamentada. O segundo, vive em um descampado (favela), não usufrui da modernização, mas tem conhecimento de sua ocorrência e sofre com suas consequências, como a poluição ambiental.

Os mitos relacionados à natureza, empregados para maldizer a tecnologia, revelamse no período anterior à implementação da Fazenda Modelo, quando o rebanho vivia livre, com espontaneidade, em farto e extenso terreno aberto. Porém, sob o novo regime, a paisagem natural é rapidamente colonizada, controlada, civilizada. A propaganda do governo entrelaça a maternidade, a grandeza nacional e a tecnologia (GINWAY, 2005, p. 101). O papel das vacas é servir aos propósitos do progresso. Repressão política e sexual identificamse. As entidades femininas - a terra e as vacas - são subjugadas. Em certo ponto, o propósito do controle da procriação é revelado:

Agora somos uma Fazenda em vias de industrialização. Nossa imagem vaise assemelhando à imagem dos grandes. Aos poucos iremos ficando louros, lisos, brancos de neve, diáfanos, transparentes, até que invisíveis, para também podermos rir das outras fazendolas que só tem “don't know how" (BUARQUE apud GINWAY, 2005, p. 102).

Como bem aponta Ginway (2005, p. 102), a eugenia, o branqueamento racial, vem para provocar no leitor um incômodo, um sentimento de perda da mistura racial que dá a nós, brasileiros, um senso de identidade. Porém, esse é um mito não consumado, resgatado de um passado irreal, construído por uma tradição literária e social sedenta por edificar uma nacionalidade.

No fim, quando as vacas se rebelam contra o sistema, o presidente Juvenal, sem remorso, aniquila o gado, tencionando utilizar o que aprendeu com tal experiência no cultivo

\footnotetext{
${ }^{50} \mathrm{R}$. Housel auxilou-nos a compreender mitos culturais envolvendo as mulheres em dois textos sucintos e claros: um em Super-heróis e a filosofia (IRWIN, 2005b) e outro em X-men e a filosofia (IRWIN, 2009b).

${ }^{51}$ BUARQUE, Chico. Fazenda Modelo. 1974. Reedição, Rio de Janeiro: Civilização Brasileira, 1997.
} 
de soja. Final que subentende uma crítica ao uso indiscriminado dos recursos naturais do país, tido erroneamente como provedor de uma reserva inesgotável.

O bem recebido pelas críticas O Fruto do Vosso Ventre (1976) de Herberto Sales ${ }^{52}$ é outra obra nacional de caráter distópico com o propósito de alfinetar a ditadura. Após a descrição de uma infestação de coelhos que ataca o suprimento de comida da ilha onde se passa a história, o temor maltusiano leva o governo tecnocrático à contenção populacional. Abortos, pílulas anticoncepcionais, controle de natalidade. No fim de um longo debate burocrático, o decreto é estipulado: crianças não poderão nascer na Ilha por quatro décadas. Grávidas serão sentenciadas à morte. Não se esteriliza os homens ou se aumenta a provisão alimentícia. Controla-se o corpo da mulher. No fim, Maria, apesar das pílulas anticoncepcionais, tem um filho com José. O menino, após trinta anos, torna-se o salvador do povo, derrubando o regime (GINWAY, 2005, pp. 103:9).

Segundo Ginway (2005, p. 105), o artifício narrativo do Messias como solução para questões com o governo rouba do povo qualquer iniciativa política (e tal crítica pode se estender à Matrix). E, ainda que a alusão à superioridade da lei natural e divina sobre a racionalidade e a tecnologia humana seja compreensível se considerarmos nossa cultura, reduzir o Brasil à tradição católica é propagar um mito de identidade nacional fictício. Afinal, a pluralidade cultural religiosa de nosso país é incontestável.

Um Dia Vamos Rir disso Tudo (1976) de Maria Alice Barroso ${ }^{53}$ enfoca a mudança no papel das mulheres na sociedade. Intercalando cenas do passado (1960) e do presente (1990) de Maria, uma jornalista aposentada, a autora potencializa o embate entre liberdade e repressão. A protagonista é uma mulher intelectual e independente amadurecendo na década de 1960, desgostosa com a conformidade social induzida pelo governo intitulado Sociedade Tecnológica de Alto Nível. A televisão multi-sensorial se alastra. A comida congelada possivelmente é drogada para diminuir a libido. "Sem pensamento original, liberdade de expressão ou paixão espontânea, o cidadão brasileiro médio é mais uma vez reduzido a pouco mais do que um robô obediente" (GINWAY, 2005, p. 115). Maria, em contrapartida, tem vários amantes, um deles casado, o que lhe faz ser julgada pelos preceitos morais tradicionais de sua empregada católica. Com dificuldade de negar esses valores, sente-se promíscua: uma prostituta.

\footnotetext{
${ }^{52}$ SALES, Herberto. O Fruto do Vosso Ventre. 1976. Reedição, Rio de Janeiro, José Olympio, 1984.

${ }^{53}$ BARROSO, Maria Alice. Um Dia Vamos Rir disso Tudo. 1976. Reedição, Porto Alegre: Mercado Aberto, 1984.
} 
Como grande marco da distopia, a corrupção e manipulação orwelliana da língua aparece nesses livros como crítica à censura da ditadura. No de Sales, há o Deconplanmilic o escritório de Controle de Natalidade e Planificação Matrimonial e Ligações Correlatas. No de Barroso, a polícia é denominada eufemisticamente de MADE (Meios Atuantes em Defesa do Estado). Essa deformação da língua, um dos símbolos da identidade de qualquer país, sugere a perda da brasilidade, da autenticidade da cultura (GINWAY, 2005, pp. 95, 104, 115). Apesar de Ginway não aprofundar o assunto, não é difícil notar que essa ideia de uma língua única por todo o Brasil é um mito. Com uma diversidade de raças tão acentuada, um território tão extenso, e contextos culturais e econômicos tão díspares, a unidade é uma quimera.

Enquanto em $O$ Fruto... temos a maternidade e a referência à Virgem Maria, em Um Dia..., Maria goza da liberdade sexual, sentindo-se culpada, julgada. No primeiro caso, a mulher, sofrida, sacrifica-se: é mero veículo passivo para a parição do salvador. No segundo, blasfema-se, mal consegue se desvencilhar dos antigos valores ainda presentes na cultura em transição. Ora é idealizada, ora é subordinada. A fertilidade da natureza e o território virgem, em $O$ Fruto..., são imagens femininas usadas para idealizar o passado e construir mitos nacionais. No fundo, meras paisagens sobre as quais atua o homem. Tudo isso reforçaria o papel subalterno das mulheres na sociedade falocrática brasileira (GINWAY, 2005, pp. 105:18).

Quando presas às polaridades limitantes sagrada $\leftrightarrow$ safada; natureza $\leftrightarrow$ tecnologia; boa má; etc.; as obras não subvertem o paradigma. Segundo Ginway (2005, p. 109), um dos benefícios da modernização foi a oportunidade de crescimento das mulheres. Educação, profissão, independência econômica e separação legal forneceram alternativas à dependência do matrimônio, da maternidade e da esfera doméstica. Algumas obras desse período indicam tais mudanças. Mesmo assim, os estereótipos e arquétipos continuaram a ser empregados e propagados.

Amparada em Michel Foucault ${ }^{54}$, Ginway (2005, pp. 117 e 125) adverte como o Estado e outras instituições sutilmente canalizam a energia sexual para promover seu poder. Nessa leitura, contudo, o problema não é reduzido em torno da industrialização, e nem é o Estado o único culpado pela repressão sexual. O poder e a coerção estão pulverizados pela estrutura social. Desse ponto de vista, as narrativas estudadas se apegaram ao mito da sensualidade como uma característica natural da identidade brasileira, ao invés de problematizar a complexidade das transformações socioculturais. Se tal reducionismo fosse

\footnotetext{
${ }^{54}$ FOUCAULT, Michel. The History of Sexuality. Nova York: Vintage Books, 1980.
} 
verdadeiro, ao se libertar do governo tirano, eclodiria uma nacionalidade ancestral e autêntica. E, finda a ditadura, isso não ocorreu. Afinal, há uma diferença entre estar livre de e livre para. No final desse segundo período, Umbra (1977) de Plínio Cabral ${ }^{55}$ e Não Verás País Nenhum (1981) de Ignácio de Loyola Brandão ${ }^{56}$ são distopias prioritariamente ecológicas e pioneiras na popularização das preocupações ambientais tão em voga atualmente: a violação da terra e a destruição da natureza. Na produção norte-americana, temas como poluição, efeito estufa, superpopulação, etc., eclodiram na década de 1960. Divididas em ecocatástrofes e ecotopias, temos obras distópicas (a desgraça e a ruína apresentam-se inevitáveis) e utópicas (a sociedade consegue equilibrar natureza e tecnologia). No Brasil, onde - uma década depois - preponderam as ecodistopias, a desigualdade entre a modernização e o meio ambiente figura a disparidade dos relacionamentos humanos dentro da própria sociedade moderna. Uma exceção é Silicone XXI (1985) de Alfredo Sirkis ${ }^{57}$ que retrata "comunidades agroespirituais" em serena relação com a ordem natural. Mas essa já é uma obra pós-ditadura, quando um olhar histórico permite encarar a mídia e a tecnologia como portadoras de alguns benefícios (GINWAY, 2005, p. 126).

\section{V.1.1.3 - O TERCEIRo PERÍOdo (MEADOS de 1980 ATÉ 2001)}

Em 1977, o regime militar começa a esvaecer. Em 1979, os dissidentes políticos são anistiados. Em 1985, as eleições presidenciais ainda sofrem influência militar e, em 1989, é eleito um presidente civil. Mesmo com essa abertura democrática, prevalece no Brasil uma atitude cultural elitista, com limitado público leitor.

...conforme apontou Nelson Vieira ${ }^{58}$,"para o Brasil, divisão de classe e elitismo cultural, com suas resultantes implicações de status, freqüentemente determinam a aceitação ou rejeição crítica em literatura". Para Vieira, a noção de mérito literário e o prestígio da arte elevada são indicadores do autoritarismo e da tradição patriarcal do Brasil, que demonstram uma resistência marcada à arte popular e à cultura de massa. Ele nota como vários escritores contemporâneos, com o advento da abertura política nos anos oitenta, "fecharam a lacuna entre o elevado e o baixo", via apropriações intertextuais que combinam a literatura canônica com elementos da cultura popular. Todavia, a ficção científica brasileira, eu creio, tem sofrido duplamente, primeiro por suas associações com "arte baixa" e ficção popular, e segundo, por ser um gênero imaginativo em um país que dá um alto valor ao realismo literário. A popularização do realismo mágico e do

\footnotetext{
${ }^{55}$ CABRAL, Plínio. Umbra. São Paulo: Summus, 1977.

${ }^{56}$ BRANDÃO, Ignácio de L. Não Verás País Nenhum. 1981. Reedição, São Paulo: Global, 1990.

${ }^{57}$ SIRKIS, Alfredo. Silicone XXI. Rio de Janeiro: Record, 1985.

${ }^{58}$ VIEIRA, Nelson. Closing the 'Gap' between High and Low: Intimations on the Brazilian Novel of the Future. In: Latin American Literary Review 20, No. 40. 1992.
} 
fantástico tão prevalente em outros países da América Latina não é um princípio dominante na literatura brasileira (GINWAY, 2005, p. 29).

Percebemos, assim, mais alguns paradigmas que perpassam nossa sociedade. Essa hierarquia cultural nos desagrada e, assim como Bakhtin, defendemos a voz e a imaginação popular como caminho para se vencer esses deletérios preconceitos. A esperança, como temos afirmado, reside na experimentação, no diferente, na subversão da hierarquia, no respeito ao povo, ao novo. Isso, de certa forma, já vem ocorrendo. Como assinala Ginway (2005, p. 30), existe uma crise de identidade decorrente da modernização; e a globalização promove uma troca cultural que acentua essa tensão pós-moderna. No choque e na simbiose mitológica, os filhos da crescente permuta multicultural desestruturam os antigos paradigmas, revelando-lhes as fissuras e as frestas por onde a voz popular pode ganhar terreno. Resta saber se os filhos dessa crise buscarão ser e saber mais, ou se se apegarão à comodidade do que já sabem e são. Nesse contexto, parece premente uma revolução pedagógica que dialogue com propostas como as de Freire; que prepare o indivíduo para essa revolução cultural que estamos vivendo.

No Brasil, um reflexo dessa influência cultural - principalmente americana por meio de filmes, livros e seriados populares (GINWAY, 2005, p. 142) - é a ficção científica "impulsionada pelos fãs", com os jovens renovando o gênero, atuando pluralmente em diferentes subgêneros. Isso não quer dizer que eles descriticizadamente adotaram a fíç̧ão científica como meio de expressão. Ivan Carlos Regina, por exemplo, publica em 1988 o Manifesto Antropofágico da Ficção Científica Brasileira. Nele, defendia que o Brasil canibalizasse a cultura estrangeira, elaborando contribuições genuinamente nacionais para a ficção científica.

Os principais escritores dessa geração seguem linhas ideológicas distintas:

Jorge Luiz Calife assume uma postura mais universalista, escrevendo ficção científica hard tradicional, enquanto Braulio Tavares tem uma abordagem mais literária, acreditando que o gênero ganhará reconhecimento ao elevar sua qualidade literária e se aproximando do fantástico. Roberto de Sousa Causo advoga temas nacionalistas evocados em uma prosa narrativa direta, enquanto Ivan Carlos Regina propõe que a ficção científica brasileira deveria cultivar o experimentalismo e o nacionalismo literário característicos do movimento modernista brasileiro dos anos vinte. Gerson Lodi-Ribeiro também promove o nacionalismo literário, ao usar o subgênero de histórias alternativas. Tendo passado a maior parte de suas vidas no Brasil moderno, onde a tecnologia e a industrialização são parte da experiência diária, estes autores freqüentemente criticam a modernização, mas já sem idealizar a paisagem tropical edênica como parte da identidade brasileira. Embora vários deles levantem o tema da ditadura e de suas conseqüências, não demonstram o mesmo ultraje moral e o desejo de retornar aos mitos de identidade ou a um mundo pré-industrializado, como o faziam os seus predecessores distópicos. Este terceiro grupo também inclui várias 
escritoras, e retrata uma população brasileira mais multi-étnica e diversificada, enquanto também exploram temas da homossexualidade e da AIDS. O cyberpunk brasileiro combina sexualidade e tecnologia e usa personagens mulheres ou parte de minorias, para desafiar o preconceito contra outras raças ou sexualidades não-convencionais. Em resumo, eles freqüentemente partilham uma visão desconstrutiva dos mitos de identidade, enquanto retrabalham os ícones da ficção científica dentro do contexto da hegemonia norte-americana e da condição periférica do Brasil (GINWAY, 2005, pp. 34:5).

A ficção científica hard é um ramo que remete àquela primeira fase da produção anglo-americana quando, preponderantemente, utilizavam-se as ciências exatas e biológicas. Ginway (2005, p. 148) cita Gregory Benford ${ }^{59}$ que, buscando definir tal subgênero, afirma que suas histórias-problema costumam apoiar e confiar na racionalidade e na ciência, considerando-as como a solução para as dificuldades descritas na narrativa. Elementos que caracterizam a FC hard incluem: o tom analítico não emocional; o personagem experimentado ou especialista em determinado ramo de pesquisa; e, um senso de misticismo cósmico.

Uma novela nacional em que aparecem tais elementos é Os Fantasmas de Vênus (1993) de Roberto Schima ${ }^{60}$. O problema a ser sanado pela ciência é a colonização espacial. Um ponto-chave do enredo é a terraformação de Vênus, processo de alteração desse planeta para torná-lo parecido com a Terra. Por outro lado, na produção americana, a terraformação não possui conotações imperialistas, talvez por eles não possuírem em sua história recente uma neo-colonização impingida por países mais poderosos. No Arquipélago de Fernando de Noronha, os gêmeos Pedro e Miguel personificam as escolhas do Brasil em desenvolvimento: o primeiro resolve se tornar pescador; o segundo, um dos engenheiros responsáveis pela terraformização, que passa por muitas dificuldades (GINWAY, 2005, pp. 151:2).

O fracasso na colonização pode representar o fracasso da modernização nacional e dos militares quando o auxílio americano é interrompido. A história acaba servindo também como crítica à destruição da Amazônia pelo regime militar, que iniciou a "terraformação" da região, utilizando-a comercialmente para a produção de gado, incentivando o desmatamento e arriscando uma desertificação. Mesmo com essas críticas, a história não é unilateral. Miguel retorna desiludido a Fernando de Noronha e encontra-a mudada, com comércio e turistas. Sua família possui uma renda mais segura se comparada à época em que o sustento dependia

\footnotetext{
${ }^{59}$ BENFORD, G. Is There a Technologica Fix for the Human Condition? In: Hard Science Fiction, George E. Slusser \& Eric S. Rabkin. Carbondale: Southern Illinois University Press, 1986.

${ }^{60}$ SCHIMA, Roberto. Os fantasmas de Vênus. In: Tríplice Universo. São Paulo: Edições GRD, Ficção Científica GRD N 14, 1993. 15-68.
} 
exclusivamente da pesca. O desenvolvimento da ilha é sustentável, em um delicado equilíbrio com o meio ambiente (GINWAY, 2005, pp. 152:3).

O cyberpunk é outro subgênero da ficção científica. Ao contrário da ficção científica Hard, ele mostra o lado negro da tecnologia. É fruto da contracultura urbana, da fusão do natural ao artificial, com um toque de romance noir e um pessimismo frente à ciência. Usualmente, os corpos humanos são aprimorados artificialmente e a realidade virtual é lugar comum - palco de atuações dos hackers que tentam invadir sistemas que concentram poder corporativo. A enorme quantidade de informação, a vida acelerada, as descrições barrocas, densas e cínicas da corrupção e da usura conseguem captar efetivamente o novo mundo. Porém, pairam sobre parco distanciamento crítico-político e nenhuma indicação de caminhos alternativos para a reestruturação social (GINWAY, 2005, p. 157).

Roberto de Sousa Causo ${ }^{61}$ estudou a aparição no Brasil daquilo que denominou tupinipunk. Existem diferenças com a produção americana: só os personagens principais incorporam aperfeiçoamentos; em vez de corporações multinacionais, abordam-se conspirações internacionais; o cerne da trama, a sexualidade e a violência se passam no submundo urbano, real e não no mundo virtual; as violências políticas são propositalmente abordadas, metaforizadas na agressão sexual. O corpo, dessa forma, torna-se "espaço de resistência cultural” (GINWAY, 2005, p. 155:9). Exemplos típicos são: Silicone XXI, citado anteriormente, Santa Clara Poltergeist (1991) de Fausto Fawcett ${ }^{62}$ e Piritas Siderais: Romance Cyberbarroco (1994) de Guilherme Kujawski ${ }^{63}$. Todos eles, em algum âmbito, subvertem os antigos mitos nacionais; e, canibalizam e abrasileiram mitos estrangeiros.

Por exemplo, ao valorizar a metáfora da expressão corporal - a coreografia - em contraste com a cultura letrada, escrita, tais obras indicam que o local da originalidade cultural reside na imprevisibilidade popular, no carnavalesco, na tensão entre as inseparáveis alta e baixa cultura (GINWAY, 2005, p. 160). Essa leitura de Ginway aproxima-se da visão de Bakhtin, que também aponta o carnavalesco e a espontaneidade popular como elementos indispensáveis da dinâmica sociocultural.

Nos três romances, vilões ávidos por poder são ludibriados por casais humildes. Ao retratar a união espiritual e sexual entre um homem negro e uma mulher branca como uma força contra o imperialismo cultural, essas histórias distorcem os mitos estrangeiros, indicando que a cultura popular pode impregnar a tecnologia de espiritualidade, sobressaindo-

\footnotetext{
${ }^{61}$ CAUSO, Roberto de S. Tupinipunk: Cyberpunk Brasileiro. Papêra Uirandê Especial No 5, agosto de 1996.

${ }^{62}$ FAWCETT, Fausto. Santa Clara Poltergeist. Rio de Janeiro: Eco, 1991.

${ }^{63}$ KUJAWSKI, Guilherme. Piritas Siderais: Romance Cyberbarroco. Rio de Janeiro: Francisco Alves, 1994.
} 
se contra as conspirações externas e a degradação humana. Ao invés de sustentar os pólos, unem-se homens e mulheres, negros e brancos, ricos e pobres, centro e periferia, tecnologia e espiritualidade... (GINWAY, 2005, pp. 163:7).

Alguns ícones ressurgem nesse período, porém com um novo tratamento. Nas histórias brasileiras contemporâneas, Ginway (2005, p. 171) nota um fato interessante: os robôs passam a ocupar o papel do escravo revolto característico do primeiro período norteamericano. Para ela, esse temor pode ser decorrente da criminalidade, da recessão e do desemprego estrutural que sucederam à industrialização acelerada, gerando tensões de classe e raça. Em As Crianças Não Devem Chorar (1990), de José dos Santos Fernandes ${ }^{64}$, um casal, antes de sair de casa, afirma aos paparicados filhos que eles não devem chorar. Porém, após a babá colocá-los na cama, eles deságuam em lágrimas. O robô de segurança, para cumprir a prescrição, mata-os e à babá. Ginway (2005, p. 173) aponta como essa história é simbólica quanto ao temor da criminalidade por meio das famílias de elite, que acabam depositando sua segurança em tecnologias falíveis, ao invés de buscarem soluções para o problema primordial: a criminalidade agravada pelo distanciamento entre ricos e pobres com a modernização. Tal constatação certamente revela uma fissura no mito da democracia racial.

Já os computadores, ao contrário dos robôs, não sofrem a discriminação. Mesmo porque, de certo modo, os segundos estão ligados aos trabalhos braçais, enquanto os primeiros, aos trabalhos intelectuais; indicando os preconceitos culturais e o menosprezo aos trabalhos físicos - tidos como inferiores desde a escravidão. Os computadores acabam servindo como um ambiente alternativo ou imaginário para transformações culturais relativas à homossexualidade, à AIDS e ao papel das mulheres. Estabelecendo um paralelo entre os vírus de computador e o HIV, Flory escreve $O$ Consertador $(1989)^{65}$. O rapaz contratado por uma pesquisadora iguala a contaminação do computador que deve reparar ao relacionamento dela com promiscuidade e sexo sem proteção, atrasando o conserto intencionalmente para castigá-la. Com isso, ela inocula-o com o vírus da AIDS que somente ela é capaz de curar. Essa crítica aos preconceitos de classe e gênero sexual indica que as mutações sociais serão fomentadas pela tecnologia e pela doença (GINWAY, 2005, pp. 177:9).

Com o pós-modernismo derrubando barreiras culturais e sociais, os alienígenas das histórias americanas passam a ser acolhidos, pois desamparados, revelando inclusive certa graciosidade. Cremos que o exemplo mais claro disso é E.T. - o Extraterrestre (1982) de

\footnotetext{
${ }^{64}$ FERNANDES, José dos S. As Crianças Não Devem Chorar. In: Do outro lado do tempo. São Paulo: GRD, 1990.

${ }^{65}$ FLORY, Henrique. O Consertador. In: Só sei que não vou por aí! São Paulo: GRD, 1989.
} 
Steven Spielberg. Porém, em obras como essa, os seres de outros planetas acabam sendo conduzidos ao american way of life, encobrindo as diferenças culturais e falhando em fornecer outros caminhos para o encontro cultural (GINWAY, 2005, p. 183).

No Brasil, os alienígenas, que antes eram vistos com indiferença, nesse novo período assumem outros papéis, dependendo da ideologia do escritor. Por exemplo, em A Mulher Mais Bela do Mundo (1998), de Roberto de Sousa Causo ${ }^{66}$, os alienígenas chegam ao planeta e são apresentados à cultura e à tecnologia norte-americana. Em visita não premeditada a uma galeria do Soho, deparam-se com o trabalho de um fotógrafo brasileiro retratando as condições do terceiro mundo, indo embora imediatamente. Como se percebe, ao contrário do usual, os extraterrestres dessa história não representam o estrangeiro invasor do primeiro mundo, mas uma cultura em desenvolvimento que veio buscar na Terra soluções para os próprios problemas: a pobreza, a poluição, a estratificação social (GINWAY, 2005, p. 184).

Nesse último período, são comuns também histórias alternativas: enredos baseados na ideia de que a mudança de um fato histórico pode alterar completamente a sequência de eventos que conduz ao presente. Analisando e alterando o passado brasileiro, alguns autores desse período conseguem evidenciar as raízes dos mitos do nacionalismo, bem como suas implicações. Além disso, dando valor e voz aos oprimidos - índios, negros e mulheres reescrevem nossos mitos culturais, mostrando muitas vezes uma sociedade mais justa, mais igualitária.

Em Xochiquetzal e a Esquadra da Vingança (2000), Carla C. Pereira ${ }^{67}$ descreve o que aconteceria se os portugueses, e não os espanhóis, financiassem a viagem de Cristóvão Colombo. Portugal acaba dominando as três Américas, concretizando o papel do Brasil como um "gigante invisível". Xochiquetzal é uma princesa asteca que se torna segunda esposa de Vasco da Gama, uma mulher forte que não teme a guerra. Seu trato de igual para igual com os homens inverte as relações de gênero sexual características do período colonial (vide a já citada passividade de Iracema). A obra acaba "cutucando", portanto, o mito do luso-tropicalismo (que exalta a libido do homem português em suas relações com as minorias étnicas) e o mito do Brasil com potencial para grandeza como nação (GINWAY, 2005, pp. 199:200).

Um Brasil alternativo é descrito também por G. Lodi-Ribeiro. Mas suas histórias, ao invés de confirmar os mitos da grandeza, do luso-tropicalismo e da democracia racial,

\footnotetext{
${ }^{66}$ CAUSO, Roberto de S. A Mulher Mais Bela do Mundo. In: Fronteiras, ed. António de Macedo, 57-66. Cascais: Simetria, 1998.

${ }^{67}$ PEREIRA, Carla C. Xochiquetzal e a Esquadra da Vingança. In: Phantastica Brasiliana. Eds. Gerson LodiRibeiro e Carlos Orsi Marinho. São Caetano do Sul: Ano Luz, 2000. 53-72.
} 
desafiam-nos. Nos contos de Outros Brasis ${ }^{68}$, ele narra o que aconteceria se os escravos refugiados no Quilombo de Palmares se unissem aos holandeses contra a hegemonia portuguesa na segunda metade do século XVII. Descreve, também, o que aconteceria se o Paraguai, economicamente independente, tivesse vencido a desleal Guerra do Paraguai de 1865 contra a Argentina, o Brasil e o Uruguai, patrocinados pela Inglaterra (GINWAY, 2005, pp. 202:9).

Ginway (2005, pp. 212:7) dedica ainda algumas páginas às mulheres, personagens e escritoras brasileiras de ficção científica. Ela conclui que, mesmo quando escritas por mulheres, muitas obras não fogem aos estereótipos, alimentando os papéis convencionais e deixando a desejar no que se refere às inovações na forma de encarar as questões de gênero sexual no país.

\section{V.2 - ConCluindo: FicÇão Científica Como Tema Gerador e TeMa Dobradiça}

Como antecipamos, realizamos uma resenha muito seletiva - e esperamos que não distorcida - do estudo de Ginway. O intuito era mostrar que a ficção científica não está imune às influências sociais, políticas, econômicas, etc. "A fantasia é o manancial do valor" (JANIK; TOULMIN, 1991, p. 226). Ela carrega suas ideologias, decorrentes de uma contextualização espaço-temporal, e isso a possibilita ser um ótimo instrumento pedagógico, capaz de ligar o prazer pela narrativa ao prazer pela compreensão das situações-limite que impedem-impelem os indivíduos a buscar saber e ser mais. Resta à equipe interdisciplinar avaliar se existe alguma obra que se mostre interessante para ser decodificada no círculo de cultura.

A nosso ver, a ficção científica - nacional ou internacional - tem amplo potencial como tema gerador ou dobradiça. Seu estudo pode levar o jovem a experimentar a existência de uma perspectiva diferente, entendendo, dentre outras percepções, de que forma a ciência atua na sociedade e a sociedade, na ciência. Por isso o diálogo inteligente é necessário. As diferenças são importantes. Para isso, problematizam-se as narrativas buscando revelar os mitos culturais propagados pela ficção científica - seja em interpretações alegóricas ou literais - e o como e o quanto esta acaba delineando o imaginário popular; isto é, nossas mentes.

Importantíssimo notar que existe um outro caminho para utilizar a ficção científica no momento do estudo da realidade: é requisitar que os próprios educandos elaborem histórias (contos, fotonovelas, músicas, animações em stop motion...) que abordem os ícones do robô, do alienígena, da espaçonave, etc., ou ainda utopias e distopias. Pedagogicamente, não podemos restringir a fantasia criativa. Nesse processo, os valores dos estudantes serão

\footnotetext{
${ }^{68}$ LODI-RIBEIRO, Gerson. Outros Brasis. Rio de Janeiro: Papel Virtual Editora, 1999.
} 
revelados, consciente ou inconscientemente. Ótima oportunidade para problematizar os paradigmas culturais imbuídos nesses ícones.

Devemos chamar a atenção do educador! Muitas obras brasileiras e estrangeiras estão recheadas de violência explícita, erotismo e cenas sexuais ousadas. E, ainda que como educadores sintamos um impulso por problematizar essa imagem banalizada e reducionista da sociedade e da mulher, há pais que incluem, em suas incumbências protecionistas, os assuntos que são aceitáveis ou não para uma discussão escolar. Cada família considera uma idade como adequada para a problematização de questões alienantes de nossa sociedade.

Resumindo, verificamos como as obras se apegam a alguns estereótipos e a certas dualidades: o espontâneo, emocional e apaixonado (a natureza, o feminino) versus o rígido, coletivista e tecnocrático (a tecnologia, o masculino). Mesmo as obras de protesto, na ânsia por levantar a bandeira da resistência, acabam endossando mitos culturais ilusórios. Muitas delas se apegam à crítica à violência tirana, mas não abordam formas de solucionar os problemas de um país recém-industrializado. É importante buscar autores que apontem nessa direção na organização do conhecimento.

A nosso ver, a questão está na dicotomia. Enquanto a natureza, a mulher e os negros/índios/etc. forem considerados como o outro passivo sobre o qual atua o homem branco, essa hierarquia social artificial propagar-se-á. Essa alteridade incutida nos jovens permanecerá como fonte de maldades inconscientes. É premente transcender, subverter essas polaridades; compreender a interconexão entre gêneros, entre raças, entre razão e emoção, entre natureza e tecnologia. É necessário o entendimento do papel do diálogo na construção de uma sociedade menos arrogante, baseada na edificação de valores e não no consumo impensado de estereótipos. A natureza, a mulher e as minorias raciais (será que podem ser chamadas assim?) não são objetos indefesos, à espera do resgate. $\mathrm{O}$ mesmo se deve pensar dos jovens. Os sujeitos, quando não amaciados, quando devidamente estimulados, são livres, capazes e sequiosos por contribuir na dinâmica da sociedade.

Existem questões latentes em nossa cultura: os desenvolvimentos econômico, urbano e tecnológico são necessários? Quais critérios devem ser utilizados para avaliá-los? Crescimento é o mesmo que desenvolvimento? Qual a diferença entre ciência, tecnologia e técnica? Como essas diferenças se "distribuem" em países de $1^{\circ}$ e $3^{\circ}$ mundos? A nova ordem econômica é o único caminho possível no mundo globalizado?

Os dilemas da modernização são questões essenciais e que devem ser discutidas com o povo, sob o risco de as pessoas se tornarem apenas peças ignorantes de uma máquina social que gera benefícios para poucos. Precisamos repensar essa falsa democracia, o ato 
simplesmente simbólico do voto. Após a ditadura, vivemos uma pseudo-redemocratização. Re-redemocratizar a ciência é redemocratizar o conhecimento e o país. É combater um disseminado elitismo cultural criminoso. Todas essas tarefas devem ser também trabalhadas nas escolas. O propósito de tais discussões é produzir um incômodo nos educandos. É confrontá-los com a percepção verbalizada de que o conhecimento científico não está distante, fora de seus corpos, mas dentro de suas mentes, impondo-lhes situações-limite e posturas sociais que precisam ser enfrentadas.

Confessamos que sair dessa "zona de conforto" sob a qual nos afogamos é um processo doloroso. A bem da verdade, ainda agora ficamos com a sensação de que o título desta dissertação parece ludibriar aqueles que se propõem a lê-la buscando formas de ensinar física em sala de aula. Parece-nos justificável que sejamos cobrados: “onde está a física nessa verborragia?".

Onde está a ciência? Está na vida. Não em informes distantes da realidade, a serem repetidos em avaliações adestradoras. É essa percepção que nos tranquiliza. A ciência, em geral, e a física, em particular, importam para as decisões vitais. O papel pedagógico da ficção científica, nessa perspectiva, é levar da catarse ao engajamento, à transposição das barreiras axiológicas e ontológicas que distanciam o indivíduo do conhecimento e, consequentemente, da ação. Por isso mesmo, não se pode parar na catarse, no consumo da narrativa. Sua problematização direciona aos obstáculos epistemológicos que, quando superados, permitem a práxis genuína. Assim, após a problematização, tem-se de organizar o estudo e a aplicação do conhecimento. Afinal, dado o problema, o educando precisa das pistas para especular sobre sua resolução.

Com isso, em vez de propormos estratégias para uma forma de ensino tradicional (que se prende à especificidade da física deixando ao jovem a tarefa de encontrar por si próprio a importância vital das minúcias dessa visão de mundo), defendemos a proposta freiriana, que propõe a realidade como quadro geral a ser problematizado, processo no qual o jovem encontrará propósitos para enfrentar as particularidades de diferentes perspectivas (dentre elas a física, e não como a dona da verdade, mas como uma construção humana repleta de ideologias que inundam nossas mentes), usufruindo verdadeiramente os diálogos com as pessoas, os livros, os filmes e o próprio mundo. De tal modo, seu interesse poderá abarcar desde as cidades até as estrelas. Como diria Miró (s/d, p. 32):

Devemos ter os pés bem

apoiados na terra

se quisermos ser capazes

de dar um salto no ar! 
Certamente, a nossa formação distante da crítica literária levou-nos a buscar amparo crucial em Ginway, pesquisadora com muito mais bagagem para realizar uma pesquisa na direção em que desejávamos. Isso nos revela a sagacidade de Freire ao afirmar a necessidade de uma equipe interdisciplinar para conduzir o círculo de cultura. $\mathrm{O}$ mergulho nessa nova forma de ler o mundo e a cultura arrebatou-nos muitos (agradáveis) meses. Tempo nem sempre disponível em uma atuação pedagógica. O nosso propósito, ao despender inúmeras páginas desse capítulo na leitura de mundo de Ginway, era apontar para os professores de física que eventualmente tomarem contato com esta dissertação - e que talvez desconheçam essa visão de mundo - o quanto a relação da ciência com as condições que limitam os homens se refletem em nossa cultura. Ou seja, essa odisseia intentava elucidar aos leitores (e a nós mesmos, pois adentramos nesse mestrado ignorando tais visões), o quanto o ensino de física necessita passar por uma revolução em seus valores mais básicos.

...chegou o momento de reconstruirmos nossas vidas. 


\section{Capítulo VI \\ OrganizaÇÃo E APLICAÇÃo do CONHECIMENTO}

$O U$

'O DiÁlogo dos MuNDOS'

- Silêncio, silêncio! Devemos transmitir orações, preces! Devemos lançar aos espaços mensagens espirituais que demonstrem a nossa fé!

- Música, sim, música! Não hinos nacionais ou frases. Música de grande elevação e não profana. Eu sugiro composições de Giovanni Batista Pergolesi!

- E por que não Wagner?

- Insisto, exijo! Apenas os mesmos sons, sons idênticos, repercutidos!

- Mensagens de fraternidade, de amor, de amor, meus senhores!

$\mathrm{O}$ ex-seminarista afundara-se na poltrona. Era como um estranho naquele recinto tempestuoso. John Stanley firmava-se no seu eu, agarrava-se à sua teoria. Guglielmo Tancredi sugeria a mensagem de fraternidade, de amor. Otto Strauber queria a música representativa do gênio de sua raça. Outro queria o hino de sua pátria, outro ainda lembrava notas musicais. Duval apoiou o cotovelo sobre a mesa e repousou o queixo protuberante nas mãos. Afinal compreendera. O que ali se examinava, o que ali se debatia, não era uma mensagem universal, produto de certa humanidade endereçado a outra, num fabuloso diálogo de mundos. Tratava-se de colóquios individuais, particulares, onde se sobrepunha a ínfima condição do terrestre. Ouvia muitas línguas. Exclamações em francês, adjetivos em alemão, conclusões em inglês, advérbios em italiano, gerúndios em espanhol. [...] Sim, lá estava o gordo abade Carcot, em sua cátedra que era mais um púlpito. Mesmo na obscuridade podia ver-lhe as feições vincadas, os lábios grossos e salientes com laivos de lubricidade, os olhos perturbados que, como certas estampas, seguiam cada um dos pupilos por todos os cantos da sala como se só êle estivesse debaixo da mira do mestre, fôsse o único aluno, e sòmente para êle se dirigisse a lição bíblica. Ah! bem se lembrava agora. Sim, várias línguas, como era mesmo? Duval dobrou-se mais e apertou as pálpebras. Sabia ainda de cor a passagem do Gênesis: "Vinde, façamos para nós uma cidade e uma tôrre, cujo cimo chegue até o céu; e tornemos célebre o nosso nome, antes que nos espalhemos pela terra inteira. Então desceu o Senhor para ver a cidade e a tôrre que os filhos dos homens edificavam. E disse: - Eis que o povo é um, e todos têm uma mesma língua; e isto é o que começam a fazer: e agora, não haverá restrição para tudo o que êles intentarem fazer". Sim - pensou o ex-seminarista - a tôrre de Babel! Agora entendia.

Rubens Teixeira Scavone, 1965, pp. 139:40.

É chegado o momento da organização do conhecimento, sistematização que impede o diálogo de se tornar uma balbúrdia, uma torre de Babel. Evita-se, nesta etapa, um circumnavegar apenas ao redor do mundo que os jovens já conhecem; e, por outro lado, acolhe-se a visão de mundo do especialista no debate, sem que ele fale de sobre um púlpito.

Dessa horizontalidade, cria-se um plano de ação: a aplicação do conhecimento. 
No último capítulo, apontamos como a problematização da ficção científica pode surtir um efeito galvanizante. A ideia central é que, ao abordar situações-limite, o aluno não estanque, com "cara de paisagem", mas se instigue a estudar a paisagem. O estímulo à predisposição interna é uma das belezas possibilitadas pela metodologia freiriana, que não relega ao biológico questões pedagógicas. O querer requer cuidados. Acreditamos que nossa proposta, amparada na problematização dialógica da cultura, pode cumprir essa função, impelindo o educando-detetive à aventura críptica. Assumindo que esse desejo visceral pelo saber foi devidamente excitado, pensemos na próxima etapa.

Após a decodificação intersubjetiva da "cripto-narrativa", vem a organização do conhecimento. A equipe pesquisa e/ou prepara textos para as unidades de aprendizagem. Ensaios provocativos, para materializar as digressões, pro-mover a reflexão, refinar o diálogo, e não solilóquios detentores de verdades indiscutíveis a serem doadas. Assim, devolve aos educandos suas refrações do mundo de forma organizada e acrescentada. Por outro lado, o educando não pode trair-se em uma inflexível arrogância juvenil, perder-se em um labirinto de espelhos que o impeça de saber mais, de pensar ainda mais. De que adianta um detetive encarcerado em sua própria mente? A simples negação da cultura, do pensamento de outros, não implica liberdade intelectual. É importante silenciar, meditar introspectivamente, buscando atingir outra visão de mundo. Não confundamos liberdade com espontaneidade.

Liberdade é mais que simplesmente fazer o que você quiser fazer - é também ter controle sobre aquilo que você quer (ROWLANDS, 2005, p. 136).

É nesse sentido que apresentamos a ficção científica: como instrumento pedagógico que possibilita a visualização dos mitos incutidos em nossas mentes, para que, reconhecendoos, possamos nos libertar - educandos e educadores. Lembremos: o novo e o velho precisam interagir como o yin-yang. Todos somos co-intérpretes de um mundo plurissignificativo.

Se esta segunda etapa não fluir, a equipe propõe a solução: novo diálogo problematizador. Por exemplo, em Ação Cultural para a Liberdade, Freire inicia com um pequeno texto (Considerações em torno do ato de estudar) que aborda justamente a postura crítica, respeitosa e responsiva com que temos de realizar a leitura do mundo e de textos.

Já verificamos indícios de como a equipe interdisciplinar é essencial para um diálogo problematizador verdadeiramente rico. Os mitos que uma cosmovisão ignora, outra percebe. Um cientista social pode conhecer textos estimulantes que desmantelem preconceitos culturais. Um especialista em literatura pode trazer capítulos de algum livro que esquadrinhe os paradigmas pós-modernos que repercutem na arte. A questão que fica é: qual o papel do físico nesse estágio? 
Inicialmente, os valores que incorporamos durante nossa educação levaram-nos a acreditar que sua função seria preparar textos técnicos para eventuais discussões em torno da eficiência do motor a explosão, do funcionamento dos transistores, da mudança conceitual propiciada pela relatividade... Porém, percebemos que essa seria uma atitude muito reducionista do papel de um especialista científico da equipe. Além das minúcias técnicas, ele deve levar para discussão problemas relevantes referentes à relação da ciência com a verdade, a realidade, a sociedade, a política, etc. Ainda que tal direção pareça invadir assuntos caros a outras disciplinas, como a filosofia ou a sociologia, ela é apenas uma evidência de que o conhecimento não pode ser esquartejado, estilhaçado, sob o risco de se tornar irreconhecível e irreconciliável. Comparando esses fragmentos inoperantes com a indisfarçável realidade, seria de se espantar se os alunos não bocejassem com olhares inexpressivos.

Nesse caso, se a equipe optar por aprofundar questões relativas ao fazer e ao quefazer científico, ela pode consultar muitas fontes emblemáticas de textos com tal enfoque: Wukmir (1975), Bronowski (1977), Abramczuk (1981), Alves (1981), Chalmers (1983), Schwartz (1992), Bunge (2000), etc. Observando as datas desses livros, que vêm sendo publicados há décadas, é impossível não se questionar: por que ainda existem tantos mitos ao redor da ciência? Um grande motivo: porque a educação bancária ainda os propaga. Mesmo com muitos esforços para mudar essa situação, uma reformulação pedagógica substancial ainda não foi posta em prática. Justamente por isso, textos como esses precisam ser levados para discussão no círculo de cultura, para que cada indivíduo possa escolher qual visão de ciência lhe parece mais adequada, ao invés de incorporar docilmente a visão cultural dominante.

A visão que supomos dominante propaga a ciência como uma "corrente da verdade", como nova mitologia impenetrável, inacessível e milagrosa, ofício de poucos "gênios eleitos". A nosso ver, ela impede os sujeitos de perceberem-na como um diálogo inteligente com o mundo, compreensível por todos. Por meio do diálogo sobre aqueles textos, pode-se entrar em contato com uma outra visão de ciência. Pode-se vislumbrá-la como construção humana. Portanto, como cultura. Nessa concepção, a ciência é uma criação dinâmica, mutante, em que se sucedem substituições de uma ideologia construída por outra; onde cada cientista, ao procurar e defender uma simetria, uma ordem na natureza, revela seus valores. Assim, cada educando poderá escolher com maior propriedade ao comparar a visão de que a ciência é neutra e cumulativa com uma outra, que combate tal concepção como ilusória, pois considera que não há física sem metafísica e estética sem ética.

Assumiremos, agora, o papel de um membro da equipe, apresentando materiais que sirvam de pretexto para aprofundar algumas questões eclodidas na etapa anterior. 


\section{VI.1 - ORGANIZAÇÃo do CONHECIMENTO: REDUÇÃo TEMÁTICA - EXPLICANDO O MUNDO}

Supondo que o aluno despertou para o desejo de enfrentar o problema, de entender os limitantes mitos culturais, a próxima preocupação é disponibilizar materiais para que ele concretize, pavimente sua aprendizagem. Se antes ele buscava, agora acha, encontra especificidades que o auxiliam a repensar, refratar a realidade. Curioso, assimila novos conceitos, fixa novas abstrações que expliquem o mundo. Sem esse amparo, ele vaguearia como um detetive cego.

Um caminho é a equipe preparar o próprio material. Os textos sobre Matrix dos capítulos I e II, com algumas alterações, são exemplos dessa produção. Outro caminho é garimpar por textos prontos. Compêndios, livros didáticos ou de divulgação científica são úteis para aprofundar questões conceituais. Também não é difícil encontrar, como vimos acima, abordagens externalistas. Particularmente, estamos interessados aqui nos textos que aludem, de alguma forma, à ficção científica.

Onde procurar esse material? Fato é que o mercado editorial tem lançado, com frequência, livros que tratam de ciência e filosofia em filmes e seriados populares. Levando em conta que o percentual de público leitor em nosso país é baixo e que essas obras podem atrair os jovens para as livrarias, acreditamos que rechaçá-las sob o rótulo de oportunistas é que seria perder grande oportunidade. A mesma que é arruinada ao se rejeitar blockbusters meramente porque são frutos da indústria cultural. Se essas obras delineiam o imaginário popular, que ótima chance de problematizar mitos culturais! E mais, conforme afirma Umberto Eco, essa intolerância revela uma atitude aristocrática e "um desprezo que só aparentemente está voltado para a cultura de massa, mas, na verdade, está dirigido contra as massas" (ECO apud REGAZZONI, 2009, p. 129).

Avaliemos alguns exemplares desses materiais. Comecemos com quatro publicações voltadas à análise dos conceitos e aparatos científicos que permeiam as narrativas: A física de Jornada nas Estrelas - Star Trek de Lawrence M. Krauss; A Ciência de Star Wars de Jeanne Cavelos; A verdadeira ciência por trás do Arquivo X de Anne Simon; e, A ciência dos SuperHeróis de Lois Gresh e Robert Weinberg.

Sobre os autores, os quatro primeiros possuem formação científica (respectivamente: físico e astrônomo; astrofísica e matemática; bioquímica e bióloga; matemático). O quarto, além disso, é escritor de ficção científica - assim como a quinta. A contracapa do livro de Krauss revela suas intenções e dá indícios de seu leitor ideal: 
Como o universo de Jornada nas Estrelas se encaixa no universo real? Descubra os erros e acertos científicos dos criadores do seriado neste fascinante guia escrito por um renomado físico (KRAUSS, 1996, quarta capa).

Os outros livros não fogem a isso. Suas estruturas são praticamente idênticas - uma sequência de temas científicos (parecida com algumas obras de divulgação científica) entrecortada por reflexões sobre a plausibilidade dos filmes. Cria-se uma reconstrução racional de um ramo da ciência para comparar algum evento das histórias com aquilo que é tido como verdadeiro pela ciência. Os autores são bastante didáticos. Essa análise conceitual, que busca a veracidade ou inexatidão científica das obras, é legítima dentro do contexto epistemológico, e os capítulos podem, sem sombra de dúvidas, ser utilizados no círculo de cultura - sempre por meio de uma leitura crítica.

Talvez valha deixar aqui apenas uma consideração: a postura de Cavelos e Simon, no que se refere ao conhecimento científico, não é prepotente como a de Krauss, Weinberg e Gresh. Estes últimos se apegam aos fatos científicos como se fossem a verdade absoluta, e não como um paradigma limitado pela localização espaço-temporal de uma comunidade científica. Nenhum deles nomeia a filosofia da ciência que defende, mas podemos inferi-las de algumas passagens. Exemplo:

A Física não progride por meio de revoluções que destroem tudo o que existia antes, mas sobretudo por evoluções que exploram o melhor daquilo que já foi compreendido. Daqui a um milhão de anos, as leis de Newton continuarão a ser tão válidas quanto hoje, independentemente do que possa ser descoberto nas fronteiras da ciência. Se soltarmos uma bola na Terra, ela sempre cairá (KRAUSS, 1996, p. 7).

Percebemos, nos enunciados de Krauss, a crença em uma ciência baseada em acumulação linear de conhecimentos. Comparativamente, vemos que sua afirmação é basicamente contrária às ideias de $\mathrm{T}$. Kuhn, que considera as revoluções científicas como momentos fundamentais na história da ciência.

No início do livro sobre super-heróis, os autores escrevem duas páginas sob o título Uma palavra sobre a lei, justamente com o intuito de confirmar e mostrar o quanto a ciência e suas provas "não podem ser transgredidas".

A palavra "teoria" sempre incomoda não-cientistas. Eles argumentam que se algo é uma teoria, então por que o tomamos como sendo um fato? Nos últimos vinte anos, ouvimos repetidamente esse argumento, não tanto relacionado à teoria da relatividade quanto à teoria da evolução. Se é uma teoria, argumentam os criacionistas, então por que a ensinamos nas escolas como sendo uma verdade? A simples verdade é que teorias são conceitos que têm sido examinados e testados inúmeras vezes e nunca se demonstrou que estejam errados. Pequenas modificações às vezes são necessárias às teorias, mas os princípios básicos permanecem os mesmos. Quando uma 
teoria tem sido demonstrada tantas vezes que não há mais dúvidas, então, finalmente, ela é considerada uma lei, tal como as três leis da termodinâmica.

$[\ldots]$

Portanto, quando dizemos, por exemplo, que a velocidade da luz é 300.000 $\mathrm{km} / \mathrm{s}$ em qualquer lugar do universo, não há um talvez nessa afirmação. Ela é verdadeira. Não porque dizemos que é. Não porque cientistas têm as mentes fechadas. Mas porque, se não fosse verdade, então o universo não faria sentido e a ciência não faria sentido. O princípio cosmológico pode ser chamado de uma teoria, mas, na verdade, é uma lei. $\mathrm{E}$, em ciência, leis não são feitas para serem infringidas (GRESH; WEINBERG, 2005, p. 20).

No capítulo nove de tal livro, temos uma provável revelação da razão pela qual ele é escrito de forma tão incisiva. Analisando os mutantes dos $X$-Men, os autores abordam a teoria da seleção natural de Charles Darwin. Lembrando o recente debate criacionismo versus evolucionismo na sociedade norte-americana, a religião vira alvo dos autores. Eles finalmente explicitam aquilo que consideram ser o método científico.

Como deduzimos anteriormente neste livro, a palavra teoria gera muito ardor quando se debate a evolução. Um dos argumentos-padrão dos criacionistas é que a obra de Darwin é meramente uma teoria, e não uma lei, portanto não deve ser tratada como fato. Já lidamos antes com teorias, mas, desta vez, vamos percorrer passo a passo o processo que os cientistas usam para provar que uma hipótese científica é verdadeira:

Deduzir e provar uma teoria consiste de várias etapas:

1. Observar uma ocorrência inesperada ou inusitada.

2. Reunir o máximo de evidências sobre o evento.

3. Apresentar um ou mais motivos (hipóteses) que possam explicar a observação. Apresentar essas explicações através de métodos analíticos de ensaio e erro e exame detalhado dos fatos.

4. Projetar um teste que dará resultados previsíveis se a hipótese for correta.

5. Conduzir o teste e verificar os resultados. Determinar se os resultados demonstram que a hipótese (a explicação) é verdadeira.

6. Se a hipótese não for verdadeira, começar novamente com uma nova hipótese para explicar os dados reunidos e testá-los novamente usando os passos 4 e 5. Para ser considerada uma teoria viável, a mesma experiência ou procedimento deve fornecer o mesmo resultado.

7. Se for bem-sucedido, publicar os resultados em uma revista da categoria.

8. Outros devem conseguir os mesmos resultados ao realizarem o mesmo procedimento definido no artigo publicado, confirmando que as conclusões são reproduzíveis.

Após passar por todas essas etapas, principalmente a oitava, na qual outros cientistas repetem o mesmo teste independentemente e chegam à mesma conclusão, considera-se descoberta uma teoria (GRESH; WEINBERG, 2005, pp. 162:3).

Fica claro que os autores acreditam no método hipotético-dedutivo. Esses são praticamente os mesmos passos que citamos ao apresentar o método de Popper. Vale salientar 
que não temos nada contra essa filosofia. Ela deve ser defendida por aqueles que nela acreditam. O conhecimento caminha quando dialogamos respeitosamente com o mundo e com os outros. Mas os autores propagam uma prática que - infelizmente - não é tão rara na ciência: uma agressividade a outras perspectivas somada a certa arrogância tendenciosa. Entusiasmo é saudável, desprezo é lamentável. Afinal:

A especulação criativa parece ser a força que impulsiona a ciência, e não as convenções limitantes da verdade aceita (SIMON, 2000, p. 12).

Como Freire (1996, p. 63) sublinha:

Tenho pena e, às vezes, medo, do cientista demasiado seguro da segurança, senhor da verdade e que não suspeita sequer da historicidade do próprio saber.

Em oposição àquela postura, indicamos o pequeno ensaio Louca genética: o lado sinistro do domínio biológico, presente no livro X-men e a filosofia (IRWIN, 2009b), em que Andrew Burnett narra a sequência de ideias e atitudes que levaram do darwinismo biológico ao darwinismo social e às atrocidades cometidas pelos nazistas.

Verifiquemos agora três obras nacionais como contraponto àqueles quatro livros: Ciência em foco: o olhar pelo cinema, coletânea preparada por Gabriel Cid e Carlos Coimbra; e, História da ciência no cinema, volumes 1 e 2, organizados por Bernardo J. de Oliveira.

Estes três livros se diferenciam essencialmente dos outros quatro. Em primeiro lugar, são compilações de ensaios sobre diferentes filmes escritos por vários autores, o que confere um caráter menos unilateral à análise da ciência. Mas talvez a característica mais importante para tal distinção seja a formação das pessoas que neles escrevem. Se antes eram "cientistas duros" no papel de analistas do uso da ciência pelas obras da indústria cultural, agora a especialidade dos ensaístas é muito variada: antropólogos, matemáticos, cosmólogos, analistas de discurso... A própria estrutura desses três livros é muito distante dos anteriores:

Não se trata de proporcionar meramente explicações distanciadas de um conteúdo científico, tampouco de um discurso centrado somente no filme em si, mas, a partir deste, de pensar as questões por ele suscitadas (CID; COIMBRA, 2008, p. 18).

Por não se limitarem à “ciência hard" (física, química, etc.), mas abrangerem a "ciência soft" (ciências sociais, políticas, linguística, etc), os autores incentivam uma perspectiva plural, transversal e multidisciplinar riquíssima.

Foi pensando em fazer ressoar diferentes discursos, diferentes leituras, partindo de um infinito maior que suas apropriações, que este livro foi organizado. A reverberação das questões que aqui se colocam, tendo sido 
pensadas por seus autores como representativas de uma determinada leitura para questões suscitadas por um filme, nos indica a importância dos múltiplos olhares para se pensar o conhecimento, a ciência, o mundo, a natureza, o homem, de forma cada vez mais completa, sem a depuração dos complexos maquinismos que colocam em movimento a realidade. A homonímia entre o cinema e a vida, entre o pensamento e a arte, atestada pela miríade de discursos que perfazem este livro, ajuda-nos a problematizar um conhecimento dito objetivo da realidade, ao estabelecer um deslocamento da própria idéia de objetividade. Detentora de uma certa noção de neutralidade para o conhecimento científico, a objetividade, sendo qualidade emblemática da modernidade da ciência, caracterizada pelo afastamento das sensações em prol do intelecto e de um conhecimento puro, universal e formal, se contradiz e acaba por prostrar-se em sua própria definição tradicional, já que um conhecimento que não engloba a vida, o corpo, as sensações, oferece a justa possibilidade de ser entendido como parcial, duvidoso e, se quisermos, irracional, delirante. Com o cinema, a objetividade se define pela relação imediata com a realidade que se apresenta na tela, com o choque da imagem e a sensibilidade (CID; COIMBRA, 2008, pp. 19:20).

Ademais, muitos dos ensaios presentes nesses livros foram redigidos regidos por preocupações pedagógicas, tornando-os úteis para o círculo de cultura (ainda que nem todos se debrucem sobre filmes de ficção científica).

Quando se fala de ciência no cinema pensamos, primeiramente, nas ficções científicas. Mas este gênero não é, obviamente, o único gênero de filme a projetar imagens sobre o conhecimento científico, os cientistas, ou as sociedades neles centrada. Filmes de aventuras, dramas, comédias, desenhos têm também sua parcela de contribuição na formação de estereótipos, modelos e expectativas que acabam por se constituir como referências comuns pelas quais a ciência e a técnica são percebidas por grande parte da sociedade, compondo assim o arsenal simbólico no qual a opinião pública vislumbra e discute os rumos e os limites dos empreendimentos científicos e tecnológicos. Todos esses tipos de filmes são históricos, tanto no sentido de refletirem o olhar de uma sociedade ou um grupo de determinada época, como no sentido de serem agentes históricos, ou seja, elementos formadores do imaginário social. Em ambos os sentidos, podem contribuir para a compreensão da história da ciência (OLIVEIRA; B. J., 2007, p. 8).

Aparentadas a esses livros, existem algumas obras estrangeiras confeccionadas com objetivos semelhantes e que também se mostram extremamente proveitosas para a sistematização das refrações da realidade, como, por exemplo: Scifi=scifilo: a filosofia explicada pelos filmes de ficção científica de Mark Rowlands; e A Pílula Vermelha: Questões de Ciência, Filosofia e Religião em Matrix de Glenn Yeffeth. Muitos dos livros editados sob coordenação de William Irwin (2003, 2005, 2008, 2009, etc.) também tratam especificamente de produções de ficção científica.

Concluindo: naqueles primeiros livros (do estilo A ciência de...) vemos uma análise internalista da ciência e da tecnologia suscitadas pela ficção científica, enquanto nesses 
últimos (do tipo A história de... ou A filosofia de...) deparamo-nos com análises externalistas. São duas posturas proveitosas para a redução temática.

Certamente esses últimos textos renderiam muito em um debate com sociólogos, filósofos, etc., da equipe interdisciplinar. Gostaríamos apenas de tecer um último comentário sobre tal discussão no círculo de cultura. A função da redução temática é fornecer meios para que os participantes do grupo escavem, alarguem, sacudam suas formas de pensar. No que se refere à filosofia (“desejo de saber”), isso equivale a dizer que cada indivíduo confrontará sua visão de mundo com outra, buscando ampliá-la, guarnecê-la, subvertê-la. Valendo-nos de termos de Antonio Gramsci, podemos divisar a filosofia espontânea da filosofia científica (REGAZZONI, 2009, p. 16). É essa dúvida sistemática capaz de sacolejar as reflexões populares que definem o propósito pedagógico do uso de trechos daqueles livros.

Voltando à crítica literária, textos como o de Ginway são muito ricos para essa etapa do processo. Como ela realiza sua análise da ficção científica nacional a partir da década de 1960, o livro de Roberto de S. Causo (2003) mostra-se convenientemente complementar. O mesmo se dá com a tese de doutorado de Alexander M. Silva (2008). Os textos de Finisia Fideli e Jeremias Moranu no Dossiê Ficção Científica Brasileira da Revista CULT de janeiro de 1998 são também ótimos acréscimos à visão de Ginway no que se refere à moderna produção nacional. Nosso interesse aqui são as questões ideológicas subentendidas nas narrativas; portanto, vejamos alguns estudos sobre esse assunto.

Em meio a críticas mais esparsas, como as de João Carlos Moraes (1966) e Otto Maria Carpeaux - que inicialmente investiu contra o gênero e, após avaliar as principais obras, entusiasmou-se, entendendo que as peculiaridades da ficção científica eram muito interessantes (cf. MONT’ALVÃO, 2009) -, André Carneiro foi pioneiro em um estudo mais sistemático do gênero. Ele concorda com críticos que atacam a literatura digestiva da indústria cultural, com sua ardilosa linguagem pseudocientífica, que acaba nos transeducando "em conformistas do futuro mundo totalitàriamente tecnizado", pois, "mascarada de divertimento, solapa de antemão nossa resistência" (G. Anders apud CARNEIRO, 1967, p. 9). Todavia, ele considera reducionista a postura que identifica o gênero apenas a tais obras porque a "ficção científica sempre foi o veículo mais perfeito para satirizar ou combater qualquer limitação de liberdade e tôdas as ditaduras" uma vez que "o aspecto crítico sociológico de um romance de S. F. tem correlações políticas e ideológicas indisfarçáveis" (idem, p. 10). Por exemplo:

Em um romance soviético, uma nave chega a um planêta desconhecido. O capitão, ao descer, encontra sêres semelhantes ao homem. A primeira coisa que se lembra de fazer é dar um viva ao "Partido Comunista da URSS"! O cinema americano, também dominado pela propaganda ideológica, comete 
patriotadas semelhantes. Em um filme, cuja ação se passa em Marte, um último sobrevivente, cuja provisão de ar estava no fim, acha uma caverna para se abrigar. Sua primeira providência é sacar uma bandeira americana da sacola e com muita dificuldade hasteá-la lá fora. Do ponto de vista literário e artístico, "dirigismos" propagandísticos como êsses não merecem nenhum comentário (CARNEIRO, 1967, p. 11).

Mas do ponto de vista pedagógico merecem sim! A problematização dialógica pode desfiar essas propagandas, promovendo a desalienação e revelando os desafios sociais. Se pensarmos nos mitos científicos, é estarrecedor perceber que há mais de quarenta anos Carneiro já apontava que o dogmatismo do século XIX é destoante da ciência do século XX. Este século acabou, não estudamos suas ciências nem filosofias na escola, e continuamos com viseiras dogmáticas de dois séculos atrás!

A ficção científica é especulativa e livre, abordando o presente e o futuro não pròpriamente obedecendo a rígidas regras "científicas" (seria êsse um estado de espírito do século dezenove) mas sòmente com a problemática dos eternos valôres artísticos e literários, a intuição e a mensagem do escritor integrado em sua época (CARNEIRO, 1967, p. 55).

Por fim, Carneiro discute temas recorrentes do gênero, oportuno complemento às discussões dos ícones realizados por Ginway - que vimos no capítulo anterior.

Raul Fiker (1985) também analisa tal repertório e auxilia nessa discussão ao buscar na sátira, nas fábulas, etc., o nascimento da ficção científica e situar sua dinâmica no interior da teoria dos gêneros. É notável sua preocupação em compreender a ideologia por trás dos arquétipos e os clichês que nascem de sua corrosão.

Quando os arquétipos deixam de ser usados com moderação e talento, quando, esmerilhados, "envenenados", se desgastam com o uso excessivo e não criterioso, degeneram para estereótipos (FIKER, 1985, p. 70).

Outro estudioso que nos auxilia no escrutínio deste gênero é Braúlio Tavares.

Sensação de estranheza diante do mundo; crise e reafirmação da própria identidade; impulso para enfrentar grandes desafios e mudar o mundo todos esses elementos se fundem na fc e lhe dão "essa perpétua inquietação adolescente", como diz o inglês Peter Nicholls. A fc atinge sucessivas gerações de jovens porque, como todo produto da indústria cultural, ela pretende despertar algumas respostas emotivas elementares. Ela não se dirige a indivíduos, e sim a públicos; não pode se diluir em sutilezas - pelo contrário, precisa fixar com traços bem firmes os arquétipos, as imagens universais com que está lidando. Uma obra de arte literária pode levar páginas e mais páginas descrevendo nuanças de sentimentos experimentados por um personagem; uma narrativa popular tem que envolver o leitor através de descrições vívidas, ação intensa e estruturas com as quais ele se identifique facilmente.

A comparação meio simplista entre "arte" e "indústria cultural" talvez não tenha muito fundamento numa época em que as duas coisas se fundem cada 
vez mais rapidamente; mas como são conceitos ainda em uso no próprio mercado, podem ser considerados como pontos extremos de uma escala escala essa que a fc percorre por inteiro (TAVARES, 1992, pp. 15:6).

Muniz Sodré (1973) também realiza uma discussão de alguns temas, unindo-se àquela profícua análise icônica, partindo do pressuposto de que a ficção científica é um discurso produzido pela indústria cultural, fruto de uma urbs tecnológica com um humanismo decadente. Assim como naqueles estudiosos, sua pesquisa demonstra um propósito bakhtiniano (ainda que nenhum deles cite Bakhtin), pois escava as ideologias latentes nas obras, analisando “o discurso em sua enunciação" (SODRÉ, 1973, p. 17).

...a ideologia se faz presente na obra, mas esta não a diz explicitamente. A obra incita a buscar o não-dito na fala (SODRÉ, 1973, p. 20).

Assim, ele irá buscar os significados ideológicos mistificantes veiculados pela ficção científica inserida na dialética produção-consumo. Dessa forma, no bojo do léxico científico empregado por suas narrativas, principalmente aquelas do século XVIII e começo do XIX, imiscuem-se "valores da burguesia ascendente - progresso, virtude, trabalho" (SODRÉ, 1973, p. 35). Ao apagar as vicissitudes que levam da busca pelo conhecimento aos produtos tecnológicos, que ligam o sujeito-cientista ao objeto,

A ciência de que fala a FC não passa de uma alucinação ideológica. É uma espécie de reencaminhamento mental no qual se julga o objeto técnicocientífico a partir de seus usos ou suas conseqüências, operando-se uma conversão do logos ao mythos (SODRÉ, 1973, p. 38).

Esses mitos e a ligação da ficção científica ao imaginário científico de sua época originam, segundo Sodré, sua vulnerabilidade histórica ${ }^{69}$.

Linguagem ideológica e reflexo mecânico do imaginário da época, a FC leva seus autores a tomadas de posição quanto aos problemas levantados, deixando transparecer a sua visão de mundo pessoal e as suas convicções de classe. Poderíamos assim apor às narrativas de FC julgamentos de valor traduzidos em pares de oposições como conservador/progressista, esquerda/ direita, otimista/pessimista - ou outros eixos semânticos instaurados pela ideologia no plano do significado (SODRÉ, 1973, pp. 44:5, negrito nosso).

A originalidade de Sodré revela-se quando ele aponta essa visão para a questão do tempo. Qual a relação entre os valores burgueses e o tempo? Obviamente existe um desejo de domínio, pois “tempo é dinheiro". A realidade é mecanizada, os ritmos são muito bem definidos, pois a produtividade depende do controle de cada nanosegundo. Sem tempo para respirar

\footnotetext{
${ }^{69}$ É importante frisar que o trabalho de Sodré não se caracteriza apenas por uma crítica ácida à ficção científica. Ele também a admira. Contudo, como muitas das pesquisas pedagógicas que citamos na introdução parecem ignorar as implicações ideológicas do gênero, resolvemos selecionar aqui trechos que antagonizassem com aquela postura unilateral e, portanto, limitante.
} 
- quem dirá sonhar e realizar incursões pelo cosmos - a submissão de cada detalhe da vida moderna a essa negação do ócio (negócio), a disciplina, o pragmatismo, a eficiência, definem cada vez mais as paranoias das cidades: o congestionamento no trânsito, o self-service, as consultas médicas de dois minutos... No filme Metropolis, um trabalhador desfalece lutando com os ponteiros de um grande maquinário. Tanto este quanto Matrix Reloaded iniciam-se mostrando mecanismos indiferentes, engrenagens, relógios e a troca de turnos de funcionários desconsolados - indicando que viramos o século e antigas questões sociais permanecem.

Nas partes 3 e 4 de seu livro, Sodré analisa tal questão temporal tendo em vista como ela evidencia-se na linguagem, nos tempos verbais (considerando extensão, modo e aspecto), para "indicar os condicionamentos ideológicos na formação dos conceitos temporais e suas conseqüências na ficção científica" (SODRÉ, 1973, p. 75), pois "toda a FC é percorrida por um motivo maior, que é o julgamento da ciência em sua realização ideológica: o controle do tempo" (idem, p. 91, negrito nosso).

A chaga criativa do cientista não desaparece, apenas é encoberta pelo discurso apagado, impessoal e acrítico da tecnologia, que procura esconder do pesquisador o fato de que o homem é o produtor do objeto do conhecimento. Na ciência, uma vez produzido esse objeto, o trabalho progride suturado ao método, à verificação reiterável, ao tempo repetido. Mas a política de produção do objeto de conhecimento não escapa a uma psicanálise, em que tempo, história e situação existencial do cientista são postos em questão. A ciência é aberta em sua história própria, mas se constitui em espaços ideológicos. Não foi por acaso que a Física moderna se concentrou na problemática da fissão nuclear: por trás dela estão a guerra e uma orientação tecnológica precisa. A ciência que, em sua política, apaga a subjetividade do cientista, a tecnologia que esconde a identidade da ciência, são fenômenos ligados à determinação mecânica do tempo. É uma epistemologia ideologizada que garante o progresso tecnológico capitalista (SODRÉ, 1973, pp. 93:4).

Nesse sentido, as incursões da ficção científica pelo domínio do tempo são consequência de ideologias burguesas veladas. "Previsões de futuro, viagens ao passado, reelaboração da História, são claras tentativas de dominar ou controlar o tempo" (SODRÉ, 1973, p. 104). Análise muito reveladora, e que não deve ser vista de forma pessimista, pois, "embora gerada pela cultura de massa, a FC não é uma mera forma degradada de mitos, mas um mito novo em emergência no seio da formação social industrializada" (idem, p. 109).

Daí sua problematização ser uma atitude pedagógica valiosa, já que permite um escrutínio das causas das situações-limite que delimitam nossos pensamentos e atitudes no mundo atual. Ademais, não é refutando imediatamente seus arquétipos e ícones que entenderemos a ascensão desse gênero no último século. Tal negação ingênua nos impediria de compreender a dinâmica da sociedade e nossos sonhos condicionados a essa realidade. Esse vandalismo 
iconoclasta seria fonte de mais angústia e não de soluções - agonia que nos lembra o poeta com veia científica Augusto dos Anjos (1994, p. 98).

\section{Vandalismo}

Meu coração tem catedrais imensas, Templos de priscas e longínquas datas, Onde um nume de amor, em serenatas, Canta a aleluia virginal das crenças.

Na ogiva fúlgida e nas colunatas Vertem lustrais irradiações intensas Cintilações de lâmpadas suspensas $\mathrm{E}$ as ametistas e os florões e as pratas.

Como os velhos Templários medievais Entrei um dia nessas catedrais E nesses templos claros e risonhos ...

E erguendo os gládios e brandindo as hastas, No desespero dos iconoclastas

Quebrei a imagem dos meus próprios sonhos!

Em suma, como já dissemos, não concordamos com as posturas verticalizadas, que menosprezam a (ou parte da) ficção científica. O desprezo hierarquizante não é uma atitude que deva ser cultivada. O prazer e o escapismo devem ter espaço em nossas vidas, desde que não as dominem. Aliás, o escapismo pode ser educativo (RABKIN, 1977, cap. 2). E o prazer, desde que não banalizado, pode levar à emancipação (é o que propõe Piassi, 2007).

Finalizando, ainda não falamos das histórias em quadrinhos - e sabemos que muitos jovens as leem, e que muitas delas ou são, ou possuem traços de ficção científica. O estudo de Moacy Cirne (1972) é formidável para dissecar a "trajetória ciencificcional dos quadrinhos e sua ideologia" (p. 43). Em outras palavras, ele também busca encontrar na forma-conteúdo dos quadrinhos aquilo que se subentende nas reticências ideológicas. Complementar a esse estudo é o de Marco A. Luchetti (1991).

Enfim, de posse de materiais desse gênero, resta saber se existem instrumentos que auxiliem em suas análises e no exame das próprias narrativas. Por exemplo, a necessária inclusão do balanço benefício $\leftrightarrow$ malefício da influência da ciência/tecnologia na sociedade (DELIZOICOV et al., 2007, p. 69) certamente pode ser feita com base na ficção científica. Uma das formas é a primorosa sistematização realizada por Piassi em dois eixos temáticos. Antes de apresentá-los, verifiquemos sua linha de raciocínio:

Por ora, o que queremos concluir é que a abordagem de conceitos e leis científicas e de fenômenos naturais a partir de uma obra de ficção científica não pode se basear em uma simples classificação de filmes e livros em "boa ciência" ou "má ciência", como propõem vários autores, entre eles Fraknoi 
$(2003)^{70}$ e Allday $(2003)^{71}$, que dão inclusive indicações de páginas na internet que classificam as obras de acordo com esses critérios. É preciso estabelecer critérios de outra natureza que dêem conta de avaliarmos os elementos presentes na obra em função de sua proximidade ou distância com o conhecimento científico, mas que possam ir além disso e, principalmente, que não sejam baseados em escalas valorativas tão fortes (PIASSI, 2007, p.158).

Como decorrência dessa preocupação ele cria os pólos temáticos.

Ao invés de se preocupar em identificar "visões distorcidas", essa análise parte do pressuposto de que, sendo parte de um discurso socialmente construído sobre a ciência, a maior parte das obras de ficção científica apresenta posições implícitas em relação à ciência e à tecnologia. Um filme como $O$ Exterminador do Futuro, por exemplo, que imagina um futuro onde os robôs irão dominar a humanidade, veicula uma preocupação ou um medo em relação a uma tecnologia. Uma obra de Júlio Verne, por outro lado, vê na tecnologia um caminho para um mundo melhor. Essa tomada clara de posições, evidentemente, nem sempre acontece, havendo obras em que múltiplas posições em conflito se sobrepõem, formando uma trama complicada. No entanto, ao procurar situar a obra como um todo e suas partes em um esquema de polaridades, torna-se possível, a nosso ver, fazer aflorar questões ligadas ao fazer científico e a relação entre ciência e sociedade que nem sempre são identificáveis em um exame superficial (PIASSI, 2007, pp.179:80).

Ele representou esses pólos em um artigo da seguinte forma:

FILOSÓFICO

BXISTENCIAL

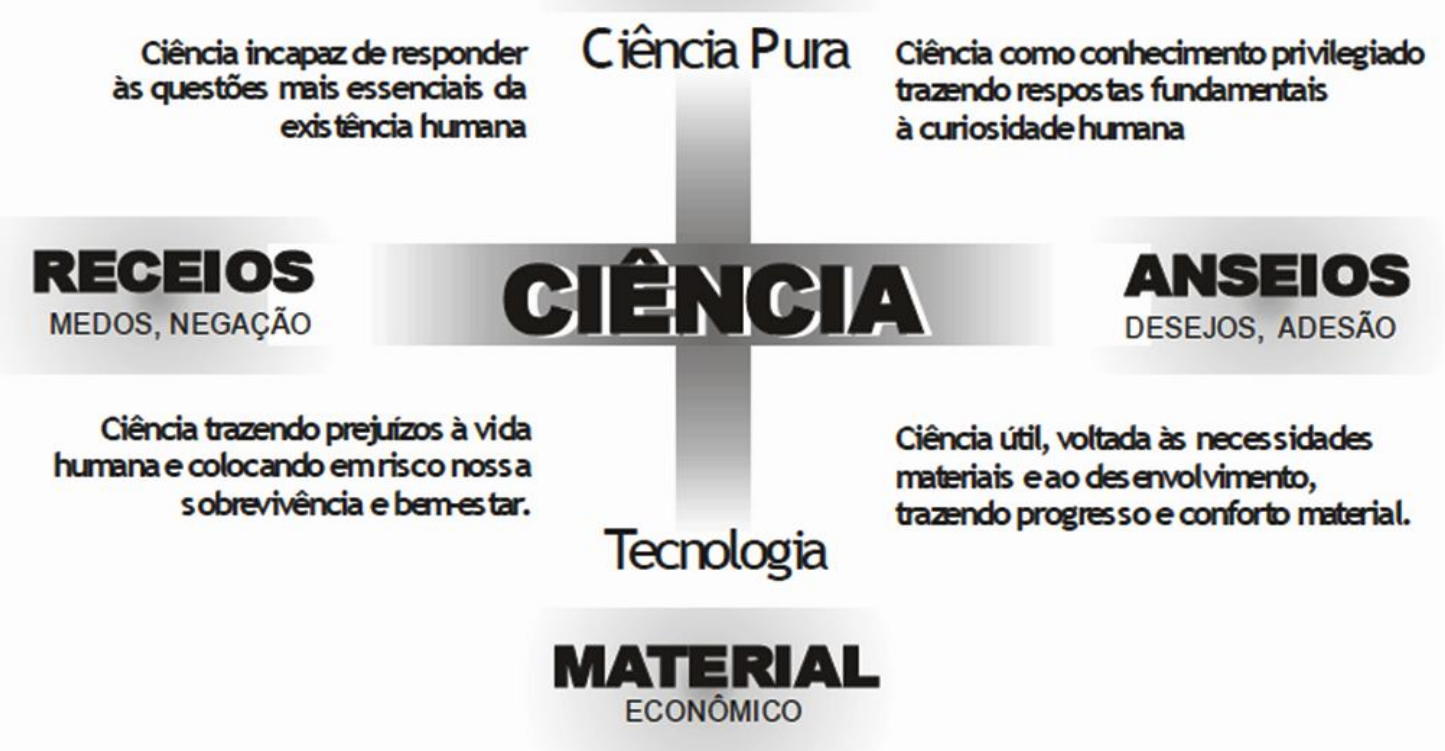

Figura VI.1.- Pólos temáticos (PIASSI; PIETROCOLA, 2007a, p. 4)

\footnotetext{
${ }^{70}$ FRAKNOI, Andrew. Teaching Astronomy with Science Fiction: A Resource Guide. Astronomy Education Review. Jul 2002 / Jan 2003.

${ }^{71}$ ALLDAY, Jonathan. Science in Science Fiction. Physics Education 38(11). January 2003.
} 
Em sua tese de doutorado, existem pequenas diferenças na apresentação desses pólos. Piassi substitui as palavras anseios e receios por euforia e disforia. Além disso, no lugar das pequenas explicações, ele enumera exemplos. Gostaríamos apenas de ressaltar um cuidado na aplicação desses eixos. Eles realmente facilitam a identificação do posicionamento e dos estereótipos eventualmente utilizados pelos autores; mas, se mal interpretados, podem cristalizar, imobilizar uma visão dicotômica na cabeça dos jovens.

Divinizar ou diabolizar a tecnologia ou a ciência é uma forma altamente negativa e perigosa de pensar errado. De testemunhar aos alunos, às vezes com ares de quem possui a verdade, um rotundo desacerto. Pensar certo, pelo contrário, demanda profundidade e não superficialidade na compreensão e na interpretação dos fatos. Supõe a disponibilidade à revisão dos achados, reconhece não apenas a possibilidade de mudar de opção, de apreciação, mas o direito de fazê-lo (FREIRE, 1996, pp. 33:4).

Reiteremos: os pólos são formidáveis. Belos em sua compreensibilidade e facilidade de aplicação. Defendemos apenas que o educador conduza seu uso de forma que o mundo não pareça um retrato em preto e branco ${ }^{72}$. O mundo é um filme. Resiliente. Colorido. E mais: um filme cujo roteiro é escrito por nós.

Para inserir essa preocupação nesses pólos, sugerimos o acréscimo de outras duas palavras: emancipação-alienação. Mas não como uma terceira dicotomia, pois receamos que elas conduzam a uma verticalização, e desta a uma opressão cristalizada, sequela de um revanchismo que confunde diferenciação com hierarquização. Propomos que, em vez de outro eixo, apresentem-se essas outras categorias como um yin-yang (que traz em si a ideia de movimento e de complementaridade). E, conforme aprendemos com Sodré logo acima, não ignoremos que esses pólos semânticos são historicizados pela ideologia em que nos encontramos.

Com essas novas categorias, mais do que identificar que outras pessoas possuem os mesmos anseios e receios que nós, inserimos na prática pedagógica a possibilidade de mudança de postura, a existência de soluções, isto é, a esperança. Em outras palavras, a euforia e a disforia possuem uma causa, que é o condicionamento social, as situações-limite que nos dilaceram. Conscientizar-se dessas situações-limite é aprender. Mudar de postura frente à vida por conta dessa conscientização é educar-se. E acreditamos ser justamente esta a pretensão por trás dos pólos criados por Piassi. Como ele mesmo afirma (2007, p. 281):

É justamente quando podemos colocar a obra ficcional em análise, frente a outras e frente à vida, com o distanciamento e a reflexão crítica que podemos

\footnotetext{
${ }^{72}$ Piassi, na defesa desta dissertação, nos chamou a atenção para o fato de que tais pólos referem-se ao discurso ficcional, e não ao mundo. Deixamos aqui, portanto, essa ressalva também para o leitor.
} 
ver o conteúdo ideológico das posições assumidas, sejam elas conservadoras ou progressistas. Quando a obra fica no nível apenas inconsciente, através dos inúmeros filmes e desenhos animados, o que é ideológico passa por verdade. Quando o debate é ignorado em sala de aula, é isso que prevalece...

Ainda nessa questão dos instrumentos úteis na análise da ficção científica, gostaríamos de retomar um artigo que escrevemos há dois anos (OLIVEIRA; ZANETIC, 2008). Naquela época, inebriados com nossa recente desmitificação de questões epistemológicas, acreditávamos que os estudantes compartilhariam nosso entusiasmo pelo estudo da filosofia da ciência. Naquela empolgação, esquecemos de pensar nas questões ontológicas e axiológicas. Hoje aceitamos que, se as questões epistemológicas não representarem situaçõeslimite que aflijam os educandos, provavelmente sua problematização ressoará em poucos jovens (o que, a bem da verdade, não é ruim, pois não estamos buscando uma panaceia). Agora cientes dessa preocupação, analisemos a essência daquilo que havíamos proposto.

Assumindo a proposta de T. Kuhn para o modo de funcionamento da ciência, imaginemos uma linha do tempo de paradigmas científicos. Se a ciência é uma instituição social que cresceu em poder nos últimos séculos, parece-nos apropriado identificar uma influência dos paradigmas científicos em outros âmbitos socioculturais. Nesta dissertação, estamos interessados na produção de ficção científica. A questão é: os autores de ficção científica baseiam-se nos sucessivos paradigmas científicos para elaborar suas histórias? Acreditamos que sim. Retomaremos esse ponto no próximo capítulo, ao apresentar sucintamente o trabalho de Eric Rabkin (1977).

Partindo do pressuposto de que existe essa relação entre o paradigma científico aceito em uma unidade epocal e a produção ficcional, sugerimos uma prudência dos educadores no momento de analisar as narrativas. Propomos que critiquem cada obra (ou trecho) sem desprezar seu contexto epistemológico, atentando para o paradigma em que se inseria o escritor e o paradigma em que se inserem.

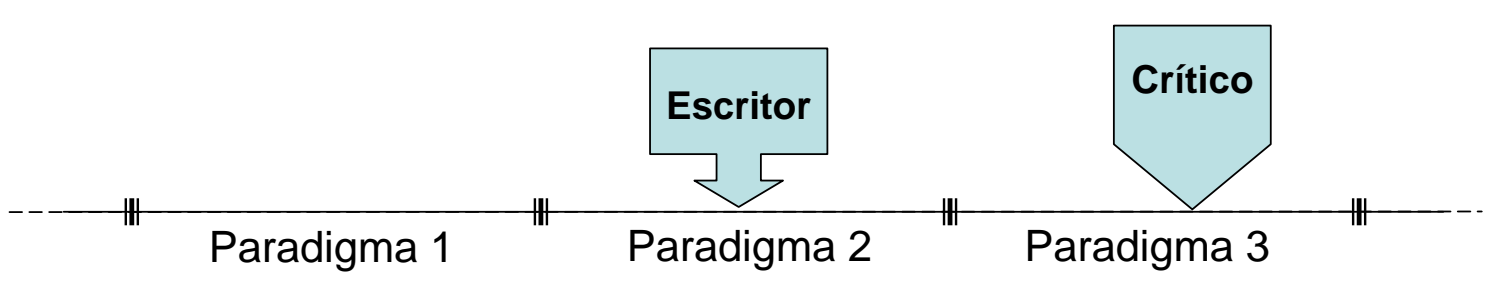

Figura VI.2.- Posição do escritor e do crítico na linha do tempo dos paradigmas científicos

Assim, seria interessante que a equipe interdisciplinar ou seus especialistas científicos possuíssem uma linha do tempo sistematizando a sucessão dos paradigmas de cada 
ramo de suas ciências. Infelizmente, elaborar essa linha do tempo para as diferentes áreas da física é um trabalho hercúleo, e não conseguimos dar cabo de tal empreitada nesta dissertação.

Essa linha do tempo pode auxiliar na percepção da linha de raciocínio de um educando, fornecendo amparo para elaborar questões conceituais que o fomentem a compreender os limites de determinada teoria. Mas, frisemos, questões epistemológicas e internalistas devem ser acrescidas de questões externalistas, sociopolíticas, essenciais para nossa emancipação cultural; sem o que seriam palavrearia estéril, pois não mudaríamos de postura frente o mundo.

Isso nos mostra que outra ferramenta útil para a equipe seria uma linha do tempo dos mitos culturais que perpassaram distintas unidades epocais. Tanto essa linha quanto aquela fornecem amparo substancial para a percepção da dinâmica das instituições sociais, compreensão vital para uma práxis pedagógica verdadeiramente atenta e libertadora. Nas mãos dos educandos, a aplicação dessas duas linhas do tempo ajudá-los-ia a reconhecer as potencialidades e limites das diferentes obras classificadas.

\section{VI.2 - APLiCAÇÃo do CONHECIMENTO: ATUANDO NO/COM O MUNDO}

Fôra pela manhã. Estava decidido. Sabia apenas que essa decisão o revitalizara e lhe dera a certeza de que vivia, de que não era insano, mas sim uma vítima até então abúlica submetida a terceiros, conquanto portadora de uma vontade. Firmado o plano, passara à ação (SCAVONE, 1965, p. 74).

A aurora de uma revolução íntima, vitalícia, se apresenta aos membros do círculo de cultura. Passados os dois primeiros movimentos - o despertar da busca de saber e ser mais e a concretização de tal busca pelo estudo científico - a consolidação da aprendizagem será efetivada pela atuação no/com o mundo. É a ação no mundo que propicia a internalização do conhecimento (DELIZOICOV et al., 2007, p. 239). E, aqui, a ficção científica também pode desempenhar papel significativo.

À primeira vista, pode-se imaginar que atuar no mundo é elaborar um experimento, criar novo aparelho ou desenvolver alguma parafernália. Mas agir na realidade não se resume a isso. A engenhosidade não é privilégio da engenharia. Produzir uma obra de arte, expressarse e criar cultura é uma forma legítima de atuação. A bem da verdade, a tecnologia faz parte da cultura. Seguindo conselho de Zanetic, para combater tal suposto mito, designaremos essa atuação de "laboratório cultural".

Nesse projeto cultural, os educandos podem ser desafiados a escrever contos de próprio punho, criar roteiros e gravar filmes, elaborar músicas ou poesias... As possibilidades 
de expressão são inúmeras. E todas caracterizam um atuar no mundo, pois a palavra expressa, carregada de valores, ideologias e filosofias pessoais, é práxis significativa - reflexão e ação. Ela pode mudar o mundo, e isso não pode ser ignorado. Deve mesmo é ser incentivado.

...aprender é uma aventura criadora! (FREIRE, 1996, p. 69).

Ademais, essa criação, essa semântica e essa sintaxe deliberada convergem fala e ação, o que, segundo Vygotsky, é fundamental para a internalização/desenvolvimento das funções psicológicas complexas, superiores, culturalmente adquiridas. O que importa, nesse processo, é que o jovem enfrente um problema do mundo, uma contradição existencial, um dilema ideológico, e busque uma solução real.

Se no estudo da realidade o educando apresentou uma criação pessoal, ele pode agora exumá-la, buscando os mitos que perpetuou irrefletidamente. Diagnostica-a com olhos de raios-X, revivifica-a, recria-a, lapida-a, restaura-a conscientemente - plasticidade que reforça a percepção de que a cultura e o conhecimento não estão mortos, estáticos. Nessa atividade revisionista, pode também digerir e reinventar o final da trama de outros autores (profissionais ou participantes do próprio grupo).

Se o educando ainda não criou um texto próprio, está na hora de desafiá-lo. Pensar com o lápis no papel é fundamental. Mas este incentivo deve ser feito de tal forma que a escrita seja relevante à vida (VYGOTSKY, 1994, p. 156). Pode-se desafiar o aprendiz a conceber uma trama reproduzindo e/ou subvertendo mitos, personificando e/ou revolvendo estereótipos, ou ainda acolhendo e permeando o texto com símbolos propositais. Perambulando pelo universo da intencionalidade, o autor-aprendiz pode aguçar sua sensibilidade para divisar tais manifestações ao se envolver com os diversos âmbitos da produção cultural.

Acreditamos que a autonomia não será imediata. Mas, ao contrário do que acontece no ensino bancário, ela será fomentada e pode ser trabalhada com o tempo. Sem a suposta segurança que os depósitos "cognitivos" podem conferir ao educando, ele certamente se sentirá inseguro, desamparado. Este é um momento em que a problematização tem seu lugar desafiador, em que engajamento se identifica com esperança.

Por exemplo, falamos no capítulo anterior das histórias alternativas. Elas possuem tremendo potencial pedagógico. Em primeiro lugar, mostram que a História não é uma sequência linear de eventos logicamente intrincados e inevitáveis. Em segundo lugar, criadas pelos educandos, estimulam-lhes a criatividade e aguçam-lhes a percepção da dinâmica da história e da necessidade de uma sucessão de acontecimentos. Distopias, utopias, tupinipunk... todos os subgêneros representam ótimas oportunidades. 
A discussão do processo de produção do conhecimento pela ciência em sala de aula, em geral é pensada em termos de um olhar para o passado, para a evolução dos conceitos Para isso, há quem proponha o desenvolvimento de atividades que incluam questões de história da ciência e a verificação dos processos pelos quais se deu a produção do conhecimento. O que a ficção científica vem a contribuir é justamente poder - sem compromisso com o factual - discutir não o que foi, mas o que poderia ter sido e o que poderia vir a ser (PIASSI, 2007, p.358).

Levados a novos limites para a própria semântica e a própria sintática, os educandos registram a compreensão dos significados das palavras e dos jogos da linguagem. Pronunciam o mundo (FREIRE, 1992, p. 93). Tal movimento propiciado pela superação intelectual permite ao educador acompanhar o processo intelectual do educando. Também permite que este vislumbre sua própria compreensão, admirando seu processo pessoal, percebendo seu particular nível de percepção das palavras, do mundo e da relação entre eles. São momentos nos quais o diálogo (e não a guerra) com outros mundos, outras visões de mundo, podem enriquecer enormemente a percepção verbalizada das nuances nas relações homens-homens e homens-mundo.

Além da criação, consideramos importante a aplicação daquilo que foi visto durante o estudo dos especialistas. É um exercício válido para que o educando-artesão desenvolva uma habilidade de encarar o mundo sobre outro ponto de vista. Por exemplo, ele pode buscar - em um conjunto de obras eleitas por ele ou pelo grupo - os mitos que descobriu durante as unidades de aprendizagem. Agindo assim, desvencilha-se do imaginário mítico que repercute no subconsciente cultural coletivo. Como cripto-analista pode, inclusive, buscar outros mitos não discutidos até esse momento.

Ademais, mais importante do que entender as alegorias apresentadas no último capítulo (robôs representam escravos, alienígenas simbolizam estrangeiros...) é tentar entender suas dinâmicas vinculadas às alterações das condições do contorno social, pois é isso que leva a uma transformação de nossos gestos diários. Repetindo: aprender é desmitificar. E mudar de postura frente aos mitos é mudar de atitude frente à vida, é reconhecer-se não só oprimido, mas também opressor. Desestereotipar-se é historicizar-se, é reconhecer que lugarcomum ocupamos quando raciocinamos e agimos, que instituição social dubla-nos enquanto falamos e pensamos.

Enfim, há um arsenal de possibilidades que podem ser debatidas e escolhidas pelos participantes. Aliás, existem também os trabalhos coletivos. Com metas afinadas, uma tarefa comum e interesse mútuo, o grupo pode: analisar mitos inconscientes e símbolos intencionais de uma narrativa; criar uma história recheada de mitos e símbolos; elaborar uma enquête a ser 
aplicada a espaços amostrais distintos para escrutinar a presença de diversos mitos em diferentes recortes da sociedade; etc.

Abrem-se as portas do imaginário justamente onde intervém a ideologia.

A avaliação também pode estar imbuída dos mesmos valores. Trocam-se as produções do laboratório cultural, um integrante corrige a criação do outro buscando os mitos que passaram despercebidos - em uma responsabilidade compartilhada. A autonomia é alimentada quando cada um reivindica seu próprio destino e o do grupo, em atividades que demandam um comprometimento. No final do processo, compilam-se os contos em um livro, os “curtas-metragens" em um DVD, os romances gráficos em uma $H Q$, etc., apresentando-os para a comunidade.

Se o grupo não se engajar em um plano de ação, problematiza-se essa situação. Todo projeto subentende crenças e valores. Se ele não se mostra contagiante, fecundo, busca-se a falha refratando-o pelo prisma ideológico.

É claro, apesar de termos procurado formas de trabalhar a ficção científica em todos os momentos da metodologia freiriana, isso não é necessário. Como disse Monteiro Lobato, a ficção científica pode ser aperitivo, ao instigar a curiosidade, alimentando o pensamento. Acrescentaríamos que ela pode também ser cripto-prato principal de refeição rica, a ser digerido e decodificado... Ou ainda sobremesa cifrada, como tema-dobradiça necessário ao debate no entender dos educadores-educandos. Pode até ser iguaria, manjar cultural saído dos frutíferos fornos mentais dos próprios educandos-educadores.

Essa é uma pedagogia da indignação, do incômodo com a própria ignorância. Nutrida sua curiosidade mais íntima, aquele que era dócil reconhece o conhecimento como alimento da alma e encaminha-se decidido rumo ao 'restaurante no fim do universo'.

A gente não quer só comida, a gente quer comida, diversão e arte. A gente não quer só comida, a gente quer saída para qualquer parte. Você tem fome de quê? (ANTUNES et al., 1987). 


\section{Capítulo VII \\ FicÇões Científicas}

$O U$

'TANGENTES DA REALIDADE'

- Pois é, Matilde. Você não entende. Muita gente não entenderia. Mas a dúvida para mim existe, com respeito aos homens. Serão suas intenções pacíficas? Terão realmente pôsto a ciência e o interêsse da humanidade acima de tudo? Êles assim o afirmam. Mas não se iluda, Matilde. Não há só cientistas envolvidos neste projeto. Há políticos. Não se esconderá por trás de tudo isto propósito de poder, de domínio, de violência?

- Lot! Essas suas dúvidas são terríveis. Trazem o germe de perturbações perigosas. Cuidado, Lot. Por que você não se contenta com a obra em si? Ela não lhe basta?

- Em verdade, não basta, Matilde. Porque é a coisa mais prodigiosa que o homem já fêz e porque pode ser um instrumento de opressão. Eu não toleraria a idéia de estar trabalhando num plano ditado pela cobiça, pelo desejo de domínio de certos homens.

- Não sei o que deu em você. É evidente que as intenções são pacíficas e puramente científicas. E a prova é que não se fêzz segredo em tôrno do Projeto Alfa.

- Seria inútil tentar fazê-lo. É um empreendimento grande demais para se poder conservar em segrêdo. Todos nós sabemos que os russos estão trabalhando em projeto semelhante. Só não sabemos em que ponto estão os seus trabalhos. E o que não sabemos, também, é o que está escondido no cérebro dos homens que governam e que mandam realizar estas obras. Êles, sim. Mantêm o mais inviolável segrêdo de suas intenções, até ao momento em que elas explodem.

- Lamento isso, Lot. Lamento que você tenha desviado seus pensamentos da obra grandiosa, para enveredar por êsses caminhos que, afinal, não nos competem. Somos cientistas, apenas.

- Competem, sim, Matilde. Somos cientistas, mas somos criaturas humanas, indissolùvelmente ligadas ao destino da humanidade.

Jeronymo Monteiro, 1969, pp. 38:9.

A potencialidade pedagógica da ficção científica emana da polifonia que the permeia. A voz dos cientistas, as angústias sociais, as questões políticas, etc., tudo isso, entremeado, é um convite à voz participativa dos educandos que, ao opinar, não estarão apenas ponderando sobre fantasias, mas sobre questões tangentes à realidade.

Porém, mais do que abrir as portas da curiosidade epistemológica, as histórias de ficção científica permitem uma imersão na retórica tão cara à ciência, tornando-se um possível caminho para a aprendizagem da gramática científica. É com esse propósito que tecemos este capítulo: confrontar algumas visões de críticos desse gênero para tentar entrever eventuais jogos da linguagem científica empregados pelas narrativas. 
A defesa que temos feito quanto à necessidade de se discutir na escola a ciência como força social, cultural, econômica, etc., é concomitante ao estorvo de uma pergunta que nos incomoda: o tempo despendido em questões externalistas impossibilitaria a aprendizagem do raciocínio lógico, da argumentação, isto é, da linguagem científica?

Acostumados como fomos a um ensino caracterizado pela exposição acelerada de informações, em que mal o professor de química acabava de falar de oxirredução, o de história já chegava falando de Venceslau Brás, não conseguimos pensar na proposta freiriana sem ficarmos intrigados: não seria a problematização dialógica uma perda de tempo? Afinal, a quantidade de conteúdos trabalhados não é inevitavelmente muito menor do que a quantidade trabalhada no ensino tradicional? E se não ensinarmos toda a matéria, como o aluno irá passar no vestibular? E como dialogar sobre conceitos físicos com jovens que não conhecem Física? Isso não é incoerente, quiçá impossível?

Meditando sobre essas contestações, percebemos implícita uma perspectiva escorada em falhas (onto)lógicas. O ritmo alucinado do professor não garante o compasso compreensivo do aluno. Sua exposição pode ser mais rápida, mas é sua, não do aluno. Não entende quem ouve passivamente, entende quem pensa-atua no/com o mundo. Aprende quem busca, não quem aceita o que não procurava.

Freire (1992) nos ensina que quando nós dizemos sem pronunciar o mundo, quando intercalamos categorias, conceitos novos, signos desconhecidos para o aluno, quando falamos e não escutamos, quando estendemos nossa lógica a quem não a entende, quando empregamos palavra distante do mundo que limita o indivíduo, quando ignoramos a "palavramundo" daquele que ouve, aí sim há tempo perdido. Só não é perdido para nós que, invadindo culturalmente, repetimos os mitos contidos nas perguntas acima para sustentar uma hierarquia em que estamos ganhando - seja ela uma verticalidade de classe, gênero, raça, crença religiosa... O tempo perdido do ponto de vista do opressor não é perda de tempo da perspectiva da humanização do oprimido.

Reconhecer que a acusação de inviabilidade temporal é um resquício de um pensamento equivocado em sua concepção de homem, conhecimento e aprendizagem foi o primeiro passo. O que tentaremos radicar no decorrer deste capítulo é a seguinte hipótese: $a$ própria ficção científica possibilita a aprendizagem da linguagem científica. Se confirmarmos isso, sua inserção na escola, que não é tempo perdido da perspectiva da emancipação cultural, também não seria uma perda de tempo para a aprendizagem da linguagem científica, reforçando nossa resposta ao por que discuti-la na escola. 
Para isso, tentaremos entender como a ciência aparece na ficção científica, apresentando a visão de alguns estudiosos desse gênero literário. Uma ressalva: Bakhtin se afasta do conceito clássico de gênero literário, baseado em tipos fixos de textos. Tal classificação dificulta a percepção das complexas relações dialógicas, das vozes heterogêneas, da polifonia que permeia cada criação cultural. Bakhtin "define os gêneros como fenômeno de pluralidade", como "rede discursiva" (MACHADO, 1996, p. 234:48). E a ideia passa a ser rastrear os (dinâmicos) gêneros discursivos (científico, literário, jornalístico, etc.) que compõem cada obra.

Os enunciados se definem pelos gêneros discursivos em uso na língua nas mais variadas esferas da comunicação social, que Bakhtin distingue em dois conjuntos: os gêneros primários e gêneros secundários. Os gêneros primários correspondem a um espectro diversificado da atividade lingüística humana relacionada com os discursos da oralidade em seus mais variados níveis (do diálogo cotidiano ao discurso filosófico ou sócio-político). Os gêneros secundários (da literatura, da ciência, da filosofia, da política), embora elaborados pela comunicação cultural mais complexa, principalmente escrita, correspondem a uma interface dos gêneros primários... (MACHADO, 1996, pp. 238:9).

Nesse sentido, a ficção científica é um subgênero, filho dos gêneros científico, literário, cinematográfico, etc. Apesar de cientes dessa concepção díspar de Bakhtin, apresentaremos neste capítulo autores que seguem o conceito mais tradicional de gênero literário. Não obstante, nosso objetivo será bakhtiniano: tentaremos rastrear o discurso científico imiscuído na ficção científica (discurso que, às vezes, apresenta-se explicitamente com características conceituais, e em outras comparece de forma analógica ou metafórica). Contudo, utilizaremos o termo jogos de linguagem de Wittgenstein, pois consideramos que ele resume melhor a ideia acima.

\section{VII.1 - BREVÍSSIMo ESBOÇO HISTÓRICO DA FICÇÃo CIENTÍFICA INTERNACIONAL}

Restringiremos esse esboço à literatura, e em termos bem gerais, apenas para permitir a contextualização de alguns termos que aparecerão no estudo posterior. Limitar-nosemos à produção internacional por considerarmos suficiente o esboço da ficção nacional baseado no trabalho de Ginway que apresentamos anteriormente.

Ainda que alguns pesquisadores busquem grandes escritores do passado que se enquadrem em alguma definição da ficção científica, o consenso parece apontar que ela surgiu mesmo foi no século XIX. E isso principalmente por conta das revoluções industriais que permitiram ao homem transformar radicalmente o meio ambiente no "curto" período de 
uma vida (SCHOEREDER, 1986, p. 14). Impressionada por essa drástica mutação acelerada, a cultura e seus produtos passaram a refletir as fantasias e as angústias relacionadas aos grandes motores dessas revoluções: a ciência e a tecnologia.

O título de Pai da Ficção Científica normalmente é atribuído ao francês Júlio Verne, cuja produção começa a ser publicada na década de 1860. O inglês Herbert George Wells, que lança seu primeiro livro em 1895, é o outro grande nome a quem se atribui a popularização do gênero. Com essas portas abertas, uma geração de escritores aproveita seus temas e estilos. Escrevem nesse período: Edgar Rice Burroughs, com suas narrativas sobre Marte sendo editadas a partir de 1911; e, Arthur Conan Doyle, que publicou O Mundo Perdido em 1912 (SCHOEREDER, 1986, pp. 18:20).

A ficção científica se alastra definitivamente no período da I Guerra Mundial, com revistas populares publicando Space Operas (uma espécie de bang-bang com pistolas de raios e naves espaciais no lugar de cavalos). A história destas revistas é conturbada: falindo, renascendo, convergindo, elas são editadas há décadas. Dentre as mais conhecidas deste período temos: Argosy All-Story, Weird Tales e Amazing Stories (SCHOEREDER, 1986, p. 20). Esta última, editada por Hugo Gernsback, começou a definir a ficção científica como um gênero distinto da fantasia ao acentuar "sua paixão pelo progresso tecnológico" (OTERO, 1987, p. 88).

Astounding Science Fiction, editada por John Campbell a partir de 1927, lança uma geração de escritores que ficou conhecida como A Era de Ouro da Ficção Científica. Nela escrevem grandes nomes: Isaac Asimov, Robert Heinlein, Alfred Elton van Vogt, Ray Bradbury, etc. (SCHOEREDER, 1986, p. 22).

Fora do círculo dessas revistas, outros grandes autores estão lançando suas obras. Aldous Huxley, por exemplo, publica Admirável Mundo Novo em 1932. E esse movimento não se restringe à língua inglesa: o escritor tcheco Karel Čapek escreve, em 1921, a peça R.U.R., em que surge a palavra robot. O russo Alexei Tolstoi descreve uma viagem a Marte em Aelita, de 1923 (SCHOEREDER, 1986, pp. 22:3). Em 1950, na Europa, ganha destaque uma nova geração: Arthur Clarke, Brian Aldiss, Stalislaw Lem, etc., todos eles usufruindo dos novos avanços científicos e tecnológicos para criar histórias bem pautadas científica e filosoficamente (idem, pp. 26:7).

As obras "mecanicistas" enfrentam uma crise quando suas previsões começam a se realizar - vide a exploração espacial. Com isso, na década de 1960, surge a New Wave ("bossa nova"). Realizando uma exploração pioneira das ciências sociais, da psicologia, da antropologia, etc., e, ousando na linguagem, a especulação adquire novos horizontes. Fazem 
parte dessa geração escritores do calibre de J. G. Ballard, Philip K. Dick e Ursula K. Le Guin (SCHOEREDER, 1986, pp. 35:7).

A partir de 1960 , de modo especial, a ficção científica tem revelado uma tendência no sentido de transferir pelo menos parte de sua ênfase da ciência para a sociedade, da máquina para o homem. Ainda diz respeito a mudanças ao nível da ciência e da tecnologia, mas essas mudanças vão mais adiante e penetram no plano social (ASIMOV, 1984, p. 28).

Todavia, os autores das gerações anteriores não se perderam desnorteados. Pelo contrário, nas décadas de 1960 e 70 eles publicam livros formidáveis. O que isso significa, isso sim, é que a ficção científica ampliou seu alcance, abrangendo perspectivas muito diversas - seja no que se refere ao conteúdo, seja na forma (SCHOEREDER, 1986, pp. 35:44). E isso permanece até hoje. Da mesma forma que a ficção científica nacional, a internacional possui atualmente autores que escrevem com um rigor científico acentuado, autores que estão mais preocupados com implicações políticas da obra, etc.

Esta também foi a dinâmica da ficção científica soviética. Asimov (1984, p. 209) enumera três etapas consecutivas de seu desenvolvimento: $1^{\mathrm{a}}$ - dominada pelas aventuras; $2^{\mathrm{a}}$ dominada pela Tecnologia; e, $3^{\mathrm{a}}$ - dominada pela Sociologia.

Finalizando, seria muito ingênuo supor que apenas os escritores de ficção científica tiram proveito da comunidade científica, mas não o contrário. Na interação social, a pilhagem é mútua. "O verbo 'afetar' é uma faca de dois gumes. A sociedade, embora afete a ficção científica é, por sua vez, por ela influenciada" (ASIMOV, 1984, p. 129). E é isso que lhe garante a possibilidade de ser usada educacionalmente. Agora, busquemos os jogos da linguagem científica presentes na ficção científica.

\section{VII.2 - Jogos dA LinguAgeM CientífiCA EMPREgados PElA FicÇão CienTífiCA}

Além de mostrar as concepções de quatro pesquisadores sobre a apropriação desses jogos pela ficção científica, para evitar distorcer aquilo que afirmam, vamos contextualizá-las no esforço por eles realizado para criar classificações abrangentes.

\section{VII.2.1 - L. DAVID ALLEN}

L. David Allen (s/d) classifica a ficção científica em três categorias gerais. A primeira é a Ficção Científica Hard, cujas obras exploram o universo narrativo a partir das ciências exatas (química, física, biologia, etc.) e suas tecnologias. A segunda denomina-se 
Ficção Científica Soft, que extrapola suas narrativas a partir das ciências humanas (sociologia, psicologia, antropologia, etc.) e as tecnologias associadas.

Tais ciências, e conseqüentemente qualquer ficção científica baseada nelas, pressupõe a existência de um universo ordenado, cujas leis são constantes e passíveis de descoberta (ALLEN, s/d, p. 21).

Essas duas categorias gerais possuem subdivisões: as histórias Extrapolativas (que projetam logicamente possíveis novidades da ciência corrente) e as Especulativas (também são projeções para o futuro da ciência corrente, mas por ser um porvir muito mais distante, isso implica em dificuldades para as previsões). A Ficção Científica Hard tem uma terceira subdivisão: histórias sobre Engenhos - com ênfase em como uma máquina funciona. Allen ainda faz a ressalva de que a capacidade de predição das ciências humanas é tida como inferior às ciências exatas (ALLEN, s/d, pp. 22:3).

A terceira categoria geral é a Fantasia Científica. Em suas histórias, o universo também é ordenado por leis encontráveis, tratadas explicitamente pelo autor. Ela se subdivide em histórias Alternativas (com leis essencialmente diferentes das que derivamos de nossas ciências atuais - entram aqui a parapsicologia, a telepatia e a magia); a Fantasia Contracientífica (o autor usa informação científica sabidamente incorreta); e o ramo denominado Espada e Magia (aventuras ambientadas em culturas que demandam armas primitivas e magia). Para ajudar a delimitar a ficção científica, Allen indica que o gênero próximo chamado Fantasia também se baseia em universos ordenados com leis descobríveis; mas, ao contrário do que ocorre na Fantasia Científica, essas leis são abordadas implicitamente (ALLEN, s/d, pp. 23:4).

Com base nas palavras usadas por Allen, inferimos que os jogos da linguagem científica empregados pelas primeiras narrativas de ficção científica estão impregnados de uma visão positivista, em que leis constantes intrínsecas (s/d, p. 29) ao ordenado universo são descobertas ao se praticar o método científico (s/d, p. 29), sendo comprovadas (s/d, p. 27), fornecendo um conhecimento sólido (s/d, p. 27).

Por exemplo, J. Verne, em Vinte Mil Léguas Submarinas, é bastante rigoroso, e inclui em suas tramas aquilo que "era válido de acordo com o conhecimento científico e a teoria em voga em 1870" (ALLEN, s/d, p. 35) ${ }^{73}$. A natureza possui "causas e efeitos descobríveis" (idem, p. 33), que permeiam as histórias em "argumentações eruditas" e

\footnotetext{
${ }^{73}$ Embora ele também cometa alguns "erros", como no caso do projétil lançado em direção à Lua por meio de um canhão sem levar em consideração a ação da aceleração sobre os viajantes e a resistência "muito quente" do ar.
} 
"preleções científicas" (idem, p. 38). Verificamos que o papel do cientista é o do mero observador, sem muito espaço para suposições ousadas.

"Senhor Professor", ele começou, "Foi um simples raciocínio de naturalista que me levou à descoberta dessa passagem. Somente eu conheço sua existência. Notei que no Mar Vermelho e no Mediterrâneo existiam muitos peixes que eram idênticos - ophidia, fiatoles, girelles, exocoeti, persegae e joels. Tendo-me assegurado desse fato, interroguei-me se não existiria comunicação entre os dois mares. Se existisse, a corrente subterrânea tinha obviamente de fluir do Mar Vermelho para o Mediterrâneo, simplesmente por causa da diferença de seus níveis. Portanto, pesquei um grande número de espécimes nas águas do Suez. Eu passei um anel de cobre através de suas caudas, e joguei-os de volta ao mar. Alguns meses mais tarde, nas costas da Síria, eu apanhei alguns deles novamente, identificados por seus anéis de cobre. Eu provei portanto que existia alguma passagem entre os dois mares. Procurei-a com o Nautilus, descobri-a, naveguei através dela, e em pouco tempo, Professor, o senhor também terá viajado através do meu Túnel Árabe!" (VERNE, 1994, p. 222, tradução livre).

Já H. G. Wells, em A máquina do tempo, desvia-se do conhecimento científico da época de seu lançamento, 1895, pois sua máquina era impraticável (e ainda o é com os conhecimentos atuais). Porém, sua história é verossímil, uma vez que ele cria uma teoria “consistente, lógica e plausível” (ALLEN, s/d, p. 46), a partir da qual constrói o restante da narrativa como uma "possibilidade lógica" (idem, p. 52). Ou seja, enquanto Verne antecipa aquilo que é provável, Wells escreve aquilo que seria possível. Eis o trecho onde ele justifica a exequibilidade da locomoção no tempo:

- Não há dúvida - continuou o Viajante do Tempo - que todo corpo real deve estender-se por quatro dimensões: deve ter Comprimento, Largura, Altura e... Duração. Mas, por uma natural imperfeição da carne, que logo lhes explicarei, somos inclinados a desprezar esse fato. Há realmente quatro dimensões, três das quais são chamadas os três planos do Espaço, e uma quarta, o Tempo. Existe, no entanto, uma tendência a estabelecer uma distinção irreal entre aquelas três dimensões e a última, porque acontece que nossa consciência se move descontinuamente numa só direção ao longo do Tempo, do princípio ao fim de nossas vidas (WELLS, 1991, p.10).

Em 1950, nos contos de Eu, robô, I. Asimov revela um "bom exemplo do uso do método científico" (ALLEN, s/d, p. 59) com suas três leis da robótica:

1. Um robô não pode ferir um ser humano, ou, por inação, permitir que um ser humano seja ferido.

2. Um robô deve obedecer as ordens que lhe forem dadas por um ser humano, exceto quando tais ordens entrarem em conflito com a Primeira Lei.

3. Um robô deve proteger sua própria existência, até onde tal proteção não entre em conflito com a Primeira e Segunda Leis (ASIMOV, s/d, p. 69).

Para Allen (s/d, pp. 60:1), tais leis permitem ao autor escrever histórias que: 
...seguem uma ordem definida: primeiramente o problema é descoberto, em seguida são reunidos e avaliados tantos fatos quanto possíveis, o que por sua vez proporciona uma teoria sobre o que está errado, o que fornece um fundamento para um conjunto de prognósticos sobre o que poderia resolver o problema inicial, e finalmente estes prognósticos são testados para descobrir se eles são corretos ou incorretos. Se são incorretos, precisam voltar atrás a alguns pontos neste processo, corrigir sua informação e teoria e tentar novamente. Este processo é o método científico, o que dá a Donovan e Powell um método para abordar os problemas que eles enfrentam de um modo sistemático. Há uma insinuação de que eles são os principais quebragalhos, precisamente porque eles aplicam o método científico tão cuidadosa e completamente, mas também com um saudável respeito à intuição.

Cotejando os passos seguidos pelos personagens Donovan e Powell com aqueles do método hipotético-dedutivo, vemos que Asimov adota a visão popperiana. Até o papel do cientista muda: ele não é mero observador, pois a intuição ganha espaço. A natureza é juíza e não berço das leis científicas. Se pensarmos que Verne pertencia a uma unidade epocal onde o positivismo era predominante e verificarmos que Asimov pertence a uma geração contemporânea às ideias de Popper, inferimos que o espírito da época realmente parece interferir em vários âmbitos da cultura.

Já a produção da geração Nova Onda é dividida por Allen em dois grupos anônimos. Um deles pode ser classificado de acordo com as categorias acima, o outro não:

...um desses grupos está principalmente interessado em experimentar novas técnicas estilísticas no campo da ficção científica, enquanto o outro grupo combina tal experimentação com a pressuposição de que não há uma ordem intrínseca no universo em que vivemos, ou pelo menos que, se houver uma ordem, essa não é acessível para ser estudada e descoberta, através do método científico (ALLEN, s/d, p. 29).

Em suma: para Allen, mais do que a fundamentação científica, o que define a ficção científica é a extrapolação lógica para além da ciência corrente, e sua verossimilhança baseiase no equilíbrio entre uma mudança e sua explicação (s/d, p. 237).

\section{VII.2.2 - UMBERTO ECO}

Umberto Eco (1989, p. 166) se aproxima dessas conclusões ao iniciar sua linha de raciocínio na seguinte divisão: existem narrativas realísticas e fantásticas (que constroem mundos estruturalmente possíveis). Subentende-se, portanto, que o universo das duas categorias possui uma estrutura, é organizado.

Nesses mundos ordenados, as histórias são construídas sobre uma série de condicionais contrafactuais (ECO, 1989, p. 166). Se ela for realista: "o que aconteceria se, 
num mundo biológica, cosmológica e socialmente semelhante ao normal, acontecessem eventos que na verdade não aconteceram, mas que todavia não são contrários à lógica?" (ECO, 1989, p. 167). Se ela for fantástica: “o que aconteceria se o mundo real não fosse semelhante a si mesmo, isto é, se a sua própria estrutura fosse diferente?” (idem, p. 167).

Enquanto Allen cria suas categorias e deixa à parte a Fantasia como uma classificação lateral que auxilia a delimitar a ficção científica, Eco classifica ambas sob as mesmas categorias. São elas: Alotopia (mundo alternativo alegórico, com fadas, magos ou animais falantes, etc.); Utopia (projeção de um mundo paralelo e inacessível, seja ele ideal e utópico ou caricatural e satírico); Ucronia (história alternativa devido a alterações em eventos de nosso passado); e, Metatopia e Metacronia (mundo futuro construído a partir de tendências do mundo real).

Como Eco diferencia a ficção científica da Fantasia? Para ele, a distinção ocorre por conta da seguinte condição: na ficção científica, a possibilidade da estrutura do mundo narrativo, a mecânica de sua modificação, é explicada "cientificamente" a partir de uma projeção das linhas de tendências do mundo atual (ECO, 1989, p. 169). Em suas palavras, o mundo "futurível" da:

...ficção científica assume sempre a forma de uma antecipação, e a antecipação assume a forma de uma conjetura formulada a partir de linhas de tendências reais do mundo real (ECO, 1989, p. 169).

Ao que tudo indica, Allen e Eco apontam na mesma direção. Aquele afirma que a obra é ficção científica caso as leis intrínsecas de seu universo sejam extrapoladas ou especuladas da ciência corrente. Eco determina se o universo é uma ou outra dependendo da verossimilhança da conjetura na qual se baseia a extrapolação de suas leis.

Insisto em ficção científica como narrativa de conjetura por um motivo muito simples: a boa ficção científica é cientificamente interessante não porque fala de prodígios tecnológicos - e poderia nem mesmo falar nisso mas porque se apresenta como jogo narrativo sobre a própria essência de toda ciência, isto é, sobre a sua conjeturabilidade (ECO, 1989, p. 170).

Dessa perspectiva, os jogos da linguagem científica que caracterizam tanto a ciência quanto a ficção científica são aqueles cuja gramática revela uma conjetura que torna admissível o inadmissível por se fundar na lógica e na racionalidade. 


\section{VII.2.3 - ERIC RABKIN}

Já Eric Rabkin (1977, p. 4) organiza sua classificação a partir do conceito de fantástico: a ocorrência repentina de algo não esperado segundo as regras básicas da narrativa e admitidas durante sua leitura. Rabkin enumera um espectro de possíveis contradições das perspectivas "naturalizadas" durante a leitura: o inesperado, o a-esperado e o anti-esperado; utilizando ainda os conceitos de realmente irrelevante e aparentemente irrelevante para abalizar a classificação.

O inesperado (unexpected) significa literalmente não-esperado, e tem pouco a ver com o fantástico. As regras da narrativa, mesmo após sua ocorrência, continuam seguindo seu inexorável curso. Exemplo: a entrada de uma personagem não mencionada anteriormente. $\mathrm{O}$ a-esperado (dis-expected ${ }^{74}$ ) é mais próximo ao fantástico. $\mathrm{O}$ texto em si não faz o leitor pensar em tal possibilidade, mas no decorrer da leitura ela se mostra dentro das regras da narrativa. Piadas lógicas, irônicas (como as d'O guia do mochileiro das galáxias de Douglas Adams) são um bom exemplo disso. Isso não quer dizer que uma piada em si seja fantástica, no sentido definido por Rabkin, pois o que caracteriza o fantástico não é o a-esperado, mas o anti-esperado (anti-expected): algo que subverte diametralmente as regras prescritas e antecipadas pela própria história. Por exemplo, uma planta falar em uma narrativa onde a regra até aquele momento era: plantas não falam (RABKIN, 1977, pp. 8:10).

O aparentemente irrelevante parece não se relacionar com o todo orgânico da narrativa, mas, de certa forma, ajuda-lhe a criar o sentido, dando suporte a algum tema principal do texto. É o caso de histórias interpoladas (como os Contos do cargueiro negro em Watchmen de Alan Moore e Dave Gibbons). Essas aparições não são, necessariamente, fantásticas. Por outro lado, o realmente irrelevante não possui ligação com as regras básicas da narrativa e, portanto, de forma alguma poderia ser fantástico.

Uma metáfora geométrica elucida tais conceitos (RABKIN, 1977, p. 12). Quando as regras básicas da narrativa revertem-se de $180^{\circ}$, quando a reconfiguração do significado sofre uma oposição diametral, este é o fantástico verdadeiro. Reviravoltas menores, de $90^{\circ}, 120^{\circ}$, com um quê de fantástico, distinguem o a-esperado. São em parte inesperadas e em parte antiesperadas. Normalmente - vide as piadas - elas preenchem expectativas que nós sequer sabíamos que possuíamos. Quanto mais estivermos realmente convencidos das regras da

\footnotetext{
${ }^{74}$ Traduzimos dis-expected como a-esperado, e não dis-esperado, para evitar confusões "sonoras".
} 
narrativa, maiores as chances de algo a-esperado resultar em uma sensação de espanto, surpresa, enfim, fantástica.

Rabkin (1977, pp. 28:9) diferencia: o fantástico (propriedade estrutural), da Fantasia (gênero literário), da fantasia, com $f$ minúsculo (a concepção leiga, incluindo a psicológica). A Fantasia faz uso do fantástico, e difere de outros gêneros literários pela natureza e pelo grau desse uso. Ele propõe que os gêneros sejam dispostos ao longo de um contínuo, ordenados em termos do aumento do uso do fantástico, com a verdadeira Fantasia em seu pólo extremo, pois é esta que auto-subverte suas regras básicas a todo momento. Alice no país das maravilhas de Lewis Carroll, devido a suas sucessivas reviravoltas, é o exemplo emblemático de Fantasia utilizado por Rabkin.

Como vemos, Rabkin define o fantástico por revoluções puramente intratextuais, ou seja, por contradições diametrais na estrutura do universo fictício: a reversão fantástica. Para ele, o fantástico está presente em toda obra de arte. O mundo é caótico, a arte é ordenada, e essa ordem é obtida por uma guinada de $180^{\circ}$ sobre algum aspecto de nossa realidade, iluminando algo que antes nos passava despercebido (RABKIN, 1977, pp. 28:30). Isso nos leva à ficção científica.

...uma obra pertence ao gênero ficção científica se o seu mundo narrativo é minimamente diferente do nosso, e se essa diferença aparece contra o fundo de um corpo organizado de conhecimento (RABKIN, 1977, p. 119, tradução livre).

Esse corpo, para ele, é o paradigma trabalhado na ciência normal como definido por Thomas Kuhn. De acordo com Rabkin, o escritor escreve sua obra tendo como base o paradigma científico aceito em sua cultura.

A diferença então, ao definir a ficção científica, refere-se a uma variação microcontextual. Quando essa variação é uma reversão completa de $180^{\circ}$ de uma regra básica (por exemplo, em um conto dominado pela mecânica quântica, a ação pode repentinamente depender do fenômeno anti-esperado da velocidade mais rápida que a luz) então o conto de ficção científica é fantástico. Se a variação é meramente o uso do a-esperado (por exemplo, vida inteligente que se reproduz por fissão), então o conto é muito menos fantástico. A variação em relação ao conhecimento aceito é uma das características definidoras do gênero ficção científica (RABKIN, 1977, p. 120, tradução livre).

Para Rabkin (1977, p. 121), boa ficção científica é aquela que faz uma, e somente uma, suposição que viola o paradigma em vigor, e extrapola o resto da história em função dela, utilizando o fantástico para escapar do mundo onde essa perspectiva é válida. Isso não quer dizer que uma obra não possa operar com o fantástico mais de uma vez sobre as normas 
paradigmáticas. Dependendo da frequência com que isso ocorre, a obra se aproxima mais e mais da Fantasia e se afasta da boa ficção científica. Para ele:

O que é importante na definição da ficção científica não é estar munido de pistolas de raio e jalecos de laboratório, mas os hábitos mentais "científicos": a ideia de que os paradigmas realmente controlam nossa visão de todos os fenômenos, que no interior desses paradigmas todos os problemas normais podem ser resolvidos, e que ocorrências anormais devem ou ser explicadas ou inicia-se a busca por um paradigma melhor (usualmente mais inclusivo). Na ficção científica, esses hábitos mentais e seu corpo de conhecimentos associado determinam a sequência de eventos, não obstante qual ciência mais obviamente forneça conhecimento ao universo narrativo (RABKIN, 1977, p. 121, tradução livre).

Ou seja, a ciência normal é tida como uma solução para qualquer quebra-cabeça imaginável. A regularidade estrutural intrínseca ao universo narrativo da ficção científica é decorrente de jogos lógicos baseados em leis previstas e bem estabelecidas por um paradigma. Daí o valor, como alegamos no capítulo anterior, de os integrantes da equipe interdisciplinar possuírem linhas do tempo dos paradigmas científicos.

Rabkin aponta, inclusive, que é possível reconhecer o paradigma empregado pelo autor por meio da linguagem utilizada. Fazendo analogia com dialeto, ele cunha o termo "grafoleto", que seria uma escrita com peculiaridades regionais espaço-temporais. Falando de J. Verne, Rabkin (1977, p. 120) afirma ser possível reconhecer o paradigma de seu período pela forma de pensar refletida por (como "soa") seu grafoleto.

Com essa base, Rabkin irá complementar seu estudo do gênero ficção científica superpondo-o a utopias, distopias e sátiras. Para ele, existem obras híbridas, como A máquina do tempo, que é uma ficção científica distópica. Isso porque ela se baseia em uma oposição diametral às leis da física clássica e, por outro lado, em uma extrapolação do evolucionismo e do determinismo histórico levando em conta o papel da tecnologia na sociedade. Como essa extrapolação implica uma divisão sinistra dos humanos em duas raças, que Wells desaprova, a obra se classifica também como uma distopia. Existem também obras utópicas e obras distópicas que não são ficção científica, pois seus universos narrativos não são apresentados em comparação a um conjunto organizado de conhecimento do nosso próprio universo. Suas extrapolações não se baseiam, por exemplo, na moderna sociologia, mas em um conjunto de pensamentos inarticulados predominantes nas perspectivas sociais de suas épocas (RABKIN, 1977, pp. 141:2).

Assim como para os outros autores, fica evidente que, para Rabkin, o universo fictício deve ser ordenado e compreensível com leis que, em última instância, são deduções da ciência normal, extrapolando-a ou revertendo-a. A única diferença é que, em sua definição, 
ele é mais específico ao tratar da ciência, pois utiliza o conceito kuhniano de paradigma, encarando a ciência como um dogma sócio-histórico.

\section{VII.2.4 - DARKO SUVIN}

Darko Suvin (1984) diferencia os gêneros de estranhamento dos naturalistas. Pertencem ao segundo grupo as narrativas que buscam reproduzir fielmente o ambiente empírico do autor (ou mundo zero, pois ele é tomado como ponto de referência). Nesse caso, o universo narrativo serve como um espelho que reflete o senso comum e as propriedades do mundo cotidiano empiricamente verificáveis. Tais narrativas pertencem ao realismo. Os protagonistas não possuem privilégios e o mundo físico da narrativa não se identifica com a ética (como acontece nos contos de fada). Quando isso ocorre, recai-se no sentimentalismo, o que caracteriza a história como uma subliteratura do realismo (1984, pp. 42:5).

Já as narrativas de estranhamento apresentam um ponto de referência radical ou significativamente distinto do ambiente empírico do autor. Se o mundo narrativo favorece o triunfo do herói com poções, magias, etc., o gênero é o conto folclórico. Porém, se esse mundo atua negativamente, deixando o herói desamparado, é a fantasia. Como nesses dois casos o mundo físico coincide com a ética, percebemos que eles provêm da mitologia. Quando não há uma subordinação do mundo físico à metafísica, e o esforço dos protagonistas não lhes garante qualquer segurança, estamos em outro ramo do estranhamento, dividido entre o pastoral (arcadismo) e a ficção científica. Nesses dois casos é possível um movimento humanizador (SUVIN, 1984, pp. 42:6).

\begin{tabular}{|r|l|l|}
\hline & Naturalista & \multicolumn{1}{|c|}{ De estranhamento } \\
\hline Cognoscitivo & literatura "realista" & FC (mais pastoral) \\
\hline Não cognoscitivo & $\begin{array}{l}\text { Subliteratura do } \\
\text { "realismo" }\end{array}$ & $\begin{array}{l}\text { metafisica: mito, conto } \\
\text { folclórico, fantasia }\end{array}$ \\
\hline
\end{tabular}

Figura VII.2 - Representação esquemática de Suvin (1984, p. 45).

Dessa forma, para Suvin:

...não deverá medir-se a ficção científica [...] em função da ciência, do futuro ou de qualquer outro elemento pertencente ao campo potencialmente ilimitado de sua temática. Antes, devemos defini-la como uma narração imaginária, determinada pelo recurso literário hegemônico de um lugar e/ou umas dramatis personae que 1) são radical ou ao menos significativamente distintos das épocas, lugares e personagens empíricos da literatura 
"mimética" ou "naturalista", mas 2), ao mesmo tempo - na medida em que a ficção científica se diferencia de outros gêneros "fantásticos"; isto é, conjuntos de contos imaginários sem validação empírica -, aceitos como não impossíveis de acordo com as normas cognoscitivas (cosmológicas e antropológicas) da época do autor. Basicamente, a ficção científica é uma contradição desenvolvida, uma irrealidade real, com seres não humanos humanizados. Outros mundos como este mundo e assim por diante. O que vem a significar - potencialmente falando - que estamos em um espaço de estranhamento poderoso, validado pelo pathos e o prestígio das normas cognoscitivas fundamentais do nosso tempo (SUVIN, 1984, pp. 10:1, tradução livre).

Quando a ficção científica escapa de sua delimitação na tabela, ela perde sua coerência enquanto gênero. Na ficção científica, algo novo e estranho (novum) ao ambiente empírico do autor gera o estranhamento (no enfrentamento de um sistema normativo fixo com um novo conjunto de normas) cognoscitivo (que supõe uma reflexão científica, criativa e dialética com a realidade) (SUVIN, 1984, pp. 27:34). O novum deve ser validado por uma lógica, uma cognição científica que é "símbolo ou correlato de um método (modo, enfoque, atmosfera, sensibilidade) idêntico ao de uma filosofia da ciência moderna. Tomada neste sentido amplo de uma cognição metodicamente sistemática, não é possível separar a ciência da inovação feita na FC" (SUVIN, 1984, p. 94).

Suvin (1984, p. 96) cita ainda a esclarecedora distinção feita por Philmus ${ }^{75}$ : “a narrativa naturalista não requer explicação científica, a fantasia não a permite e a FC a requer e a permite". Requer e permite soa à Popper. Mas a visão de Suvin é mais ampla, pois para ele o método científico abarca:

...a navalha de Occam; a dúvida metódica; a elaboração de hipóteses; os experimentos (com o pensamento) físicos ou falsificações imaginárias; a causalidade dialética e a probabilidade estatística; paradigmas cognoscitivos progressivamente mais amplos...

$[\ldots]$

...a partir de Einstein e Marx, a ciência tem sido um conjunto aberto de conhecimentos, de modo que a FC adota no papel de validação científica todo conjunto novo e imaginável que não infrinja a base filosófica do método científico vigente na época do autor (SUVIN, 1984, pp. 99:100, tradução livre).

Essa percepção da mudança metodológica de um paradigma para outro aguça sua análise da pressão que o horizonte científico exerce sobre o desenvolvimento da ficção científica. Revisando a história do gênero, Suvin aponta como ele nasce com viagens extraordinárias que buscam encantar pelas maravilhas do universo, recorrendo a

\footnotetext{
${ }^{75}$ PHILMUS, Robert M. Science Fiction: From its Beginning to 1870. In: BARRON, Neil (ed.) Anatomy of Wonder. Nova York, 1976.
} 
extrapolações tecnológicas primitivas. Mas esta foi somente sua função inicial. A geração anterior à guerra (H. G. Wells, Olaf Stapledon...) extrapola temporalmente modelos sociológicos, biológicos e cosmológicos, até chegar a um final lógico ou uma conclusão cientificamente válida. Tal extrapolação é um recurso narrativo e ideológico antes de ser um modelo cognoscitivo, e não é ela que define as melhores obras (1984, pp. 48:54).

O retorno ao berço, que foi a produção de Space Operas na geração de $\mathrm{H}$. Gernsback, deformou o progresso do gênero ao explicar o sobrenatural com uma ciência também sobrenatural, "nem cognoscitiva nem mágica - e sim uma vergonhosa tentativa de fazer passar por cognição uma ideia juvenil de magia" (SUVIN, 1984, p. 49).

Para Suvin, o modelo analítico da ficção científica se baseia mais na analogia do que na extrapolação. Aquela abrange esta. As analogias filosófico-antropológicas (como as obras de Stanislaw Lem e Ursula K. Le Guin) unem novas cosmovisões com aplicações práticas voltadas aos problemas do nosso mundo. Libertando-se do racionalismo das gerações anteriores, elas "devem ter um final aberto, por analogia com a cosmologia, a epistemologia e a filosofia da ciência moderna" (1984, p. 56).

A análise de Suvin é extremamente mais densa do que essa breve e truncada amostra. Mas cremos que isto já nos permitiu exemplificar o que gostaríamos.

\section{Em suma, como a ficção científica emprega os jogos da linguagem científica?}

Como aprendemos com o estudo acima, cada paradigma científico apresenta uma forma de pensar peculiar que influencia o "grafoleto" empregado pela ficção científica.

Pensemos em escritores influenciados pela lógica hipotético-dedutiva. Seja a narrativa construída com base em uma ciência exata ou humana, ou mesmo uma magia, ela sempre seguirá as mesmas premissas: universo ordenado, leis constantes e compreensíveis. E são essas leis que permitem extrapolações e especulações cuidadosas conduzidas por "uma estrutura lógica de conexões" (ALLEN, s/d, p. 151). Ou seja, no compromisso racional desta geração da ficção científica, sua plausibilidade e sua consistência sustentam-se em um discurso lógico argumentativo da seguinte forma:

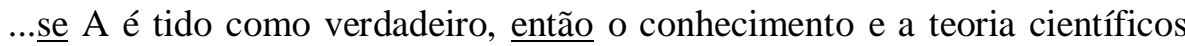
correntes declaram que $\mathrm{B}, \mathrm{C}, \mathrm{D}$ etc. ou devem, ou podem válida e logicamente seguir-se (ALLEN, s/d, p. 121, grifos nossos).

Essa conclusão permite-nos abrandar aquela questão apresentada no início do capítulo. Existem escritores de ficção científica que se alinham a diferentes correntes 
epistemológicas. Se o educador pretende que o educando discuta e aprenda a forma de pensar de determinada corrente, é possível buscar produções que a incorporem.

Respondendo à pergunta inicial desta dissertação: podemos afirmar que, se a preocupação é a aprendizagem da lógica revelada na retórica científica, a própria imersão no universo da ficção científica permite a familiarização com os meandros da argumentação racional, ou seja, com os jogos da linguagem científica. Portanto, finalmente concluímos que a imersão no universo da ficção científica pode ser proveitosa não só para a compreensão de questões externalistas, como defendemos nos dois últimos capítulos, mas também para a compreensão da própria gramática científica.

A discussão da ficção científica tem muito a acrescentar à educação bancária, que supõe a linguagem como mero conjunto de etiquetas indestrutíveis, batismos recordáveis que saltam perante o espírito quando suscitados. Ensinaram-nos Bakhtin e o segundo Wittgenstein que aprender determinados procedimentos da linguagem é aprender uma outra forma de pensar, e que não se aprende a pluralidade do pensar decorando definições. Deve-se garantir ao estudante a vivência da significação da palavra, isto é, ele precisa experienciar ao máximo seu uso. E se "o modo de agir comum a todos os homens é o sistema de referência, por meio do qual interpretamos uma linguagem desconhecida" (WITTGENSTEIN, 1999, p. 93), não devemos negar aos educandos a vivência da práxis científica, se quisermos que eles aprendam sua linguagem. Nesse sentido, a ficção científica permite uma familiarização com a gramática científica, integrando-se a sua significação, combatendo o reducionismo que a apresenta em definições dicionaristas e em limitados algoritmos de resolução de exercícios.

...a ficção científica, talvez mais do que qualquer outro gênero, depende do senso de jogo intelectual do leitor - isto é, a voluntariedade de iniciar com a pergunta "O que aconteceria se...?" ou "Como seria se...?" e seguir o desenvolvimento lógico de perguntas possíveis até um fim (ALLEN, s/d, p. 269).

A ficção científica é uma forma de instigar o raciocínio lógico. Ainda que muitas de suas obras sejam banhadas de transgressões das leis da natureza, elas não transgridem uma lei: a de haver leis! As novas leis da natureza apresentadas são tratadas com a mesma seriedade com que um cientista estrutura suas teorias. No fim das contas, a ficção científica se mostra como um exercício válido para aprender a operar com a gramática usada quando se enunciam regras. Regras que ordenam o universo. Ordem explicitada em uma especulação cuja existência é construída, suposta pelo autor: seja ele um cientista ou um ficcionista.

E mais importante do que se familiarizar com a gramática científica em contextos diversos, é saber aplicá-la em contextos diversos. Daí termos afirmado, no capítulo anterior, 
que a criação narrativa por parte dos próprios educandos é essencial para a consumação da aprendizagem. Ao tentar aplicar esses jogos da linguagem, eles aprenderão a operar com eles, solidificando sua compreensão.

Mas uma atividade pedagógica implica intervenções. Mais importante do que incentivar o jovem a mergulhar na leitura das narrativas, é criar formas de potencializar essa imersão. Ao entrar em contato com o universo narrativo, o jovem encontrará uma quantidade infinita de diferentes jogos de linguagem, alguns com origem na física, outros na política, outros na psicologia, etc. No meio dessa polifonia, o educador interessado em garantir a aprendizagem da argumentação científica chama a atenção dos educandos para a gramática característica desta linguagem.

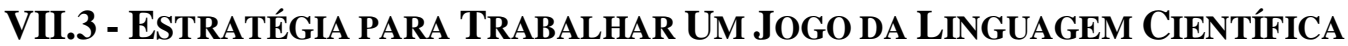

Vimos que a espinha dorsal de um dos jogos de linguagem que a ciência e a ficção científica compartilham é:

Se (premissa), então (possibilidade).

Tal estrutura evidencia uma "seqüência cronológica-causal de acontecimentos" (ALLEN, s/d, p. 239). Elucidando:

Se (causa), então (consequência).

Essa não é a única estrutura lógica utilizada pela ciência. De posse de um livro de gramática, uma folheada no capítulo referente aos períodos compostos instiga-nos a selecionar outras orações subordinadas e a criar diferentes estratégias para abordar a gramática científica em sala de aula. Porém, no restante do texto, nos restringiremos às orações subordinadas adverbiais do tipo condicional representadas pela estrutura acima.

Condição é o fato real ou hipotético necessário à realização ou não realização de outro fato. As orações subordinadas adverbiais condicionais exprimem condições (reais ou hipotéticas) para que se realize ou deixe de realizar o fato expresso na oração principal. A conjunção mais utilizada para introduzir essas orações é se; além dela, podem-se utilizar caso, contanto que, desde que, salvo se, exceto se, a menos que, uma vez que (seguida de verbo no subjuntivo) (INFANTE, 1996, p. 427).

Nesta definição, fica evidente que a possibilidade do universo fictício é uma circunstância condicionada a outro fato: a premissa. Se pensarmos na ciência, isso elucida 
seus cernes: a crença na ordem e na causalidade. As já citadas três leis da robótica de Asimov, por exemplo, são expressas por esse tipo de oração condicional.

Podemos completar aquele raciocínio lógico por meio de uma terceira oração, incluída para concluir, arrematar o raciocínio das orações subordinadas. Desta forma, ampliaríamos a estrutura geral para algo assim:

Se (causa), então (consequência). Portanto (lei).

Esta terceira oração não traz uma informação nova, mas apenas reorganiza as informações anteriores, evidenciando a lei que delas resulta. Por exemplo:

Se aqueço água a $100^{\circ} \mathrm{C}$, então ela entra em ebulição.

Portanto, a temperatura de ebulição da água é $100^{\circ} \mathrm{C}$.

Essa terceira oração é sintaticamente independente das anteriores e designa-se oração coordenada sindética conclusiva. "A coordenação de orações permite relacionar fatos de importância equivalente" (INFANTE, 1996, p. 439). A organização permitida por essas três frases é um recurso estruturador característico de uma gramática científica e, portanto, é também um recurso estruturador dessa forma científica de pensar.

A aplicabilidade dessa tríade se-então-portanto para evidenciar a lógica por trás do raciocínio científico parece abrangente. Se escolhermos algum dos vocábulos do Catálogo de invenções e termos da FC de Gilberto Schoereder, podemos exemplificar melhor isso. Optemos por algo muito difundido na literatura, no cinema e nos seriados:

Salto - [Isaac Asimov] - um salto entre uma região do espaço e outra, através da região conhecida como superespaço, ou hiperespaço. No salto, atravessa-se uma distância de vários anos-luz entre uma estrela e outra em apenas alguns segundos.

Superespaço - [Isaac Asimov] - o mesmo que hiperespaço. Sabe-se que o super-espaço é uma "região impossível de imaginar", que não é espaço nem tempo, matéria ou energia, algo ou nada (SCHOEREDER, 1986, pp. 151:2).

Apliquemos a tríade para revelar a lógica por trás do hiperespaço.

Se existe uma região "fora" do universo (um "metaespaço" chamado hiperespaço),

então uma nave pode utilizá-la como um grande atalho cósmico.

Portanto, é possível dar saltos espaciais (e sem ultrapassar a velocidade da luz!).

Está aí um instrumento de auxílio à compreensão da lógica por trás do universo científico ou fictício. Em trechos com raciocínios mais complexos do que o do exemplo acima (pense na criatividade desconcertante de Philip K. Dick - a propósito, brilhantemente 
dissecada pelo psicanalista Jurandir Freire Costa, 2009), basta reorganizar o discurso "bagunçado" e aparentemente incompreensível a partir dessa tríade. Ela aclara a lógica por trás do discurso. Após a organização, fica mais fácil perceber quais são as premissas que sustentam o discurso e, destarte, questioná-las. É possível também realizar uma cadeia de enunciados baseados na tríade, em que a consequência de um período será a premissa do outro, revelando previsões cada vez mais especulativas. Aplicando a tríade, o educando reestrutura sua forma de pensar, o que potencializa a aprendizagem de uma forma de argumentação científica.

Toda essa reflexão pode ser refinada por meio, por exemplo, dos trabalhos sobre argumentação realizados ou orientados por Anna Maria Pessoa de Carvalho (exemplos: CAPECCHI, CARVALHO, 2000; BARRELO, 2010). Mas este aprofundamento não é nosso foco aqui, pois nesta dissertação estamos mais preocupados em embasar o 'como utilizar a ficção científica?' em um 'por que utilizar a ficção científica?'.

Apenas tomemos um trabalho para mostrar que esse aprofundamento pode se tornar manco se cometermos um equívoco. Neste trabalho (CAPECCHI, CARVALHO, SILVA, 2002), os autores analisam a interação acertadamente dialógica entre o professor e os alunos enquanto tentam desvendar o modo de funcionamento de um forno micro-ondas. Em nossas aulas, atuamos desta forma com muita frequência. Para nossa surpresa, com a mesma frequência existem alunos que não se encantam com o experimento e verbalizam: "para que serve isso?".

Preocupados com essa situação, formulamos algumas perguntas: como um experimento relacionado às micro-ondas implica a emancipação do estudante? Qual situação-limite essa atividade problematiza? Que prisão para a mente ela questiona? Como ela se torna significativa para os educandos a ponto de eles mudarem de postura frente à vida? Ou, aumentando a dramaticidade, recordando a frase de Camus citada no capítulo IV: como a compreensão do funcionamento de um forno micro-ondas é capaz de tocar um jovem que, de tão massacrado pelo mundo, de tão esfarrapado, demitiu-se do próprio querer e não vê prazer em viver?

Ponderando dessa forma, percebemos que nossa atuação revelava um equívoco (pelo curto artigo, fica difícil dizer se o professor estudado pelos autores faz o mesmo). Desmontamos muitos aparelhos com os alunos partindo de um pressuposto: "durante o diálogo investigativo, eles se familiarizariam e, por fim, compreenderiam como se dá a argumentação científica". Façamos uma pergunta sobre tal premissa: por que os alunos precisam conhecer a argumentação científica? E, das muitas respostas que formulamos, percebemos que uma era recorrente: “a aprendizagem específica da argumentação científica 
desenvolve funções cognitivas que, de alguma forma, impulsionam inúmeras outras funções cognitivas necessárias para a vida". Foi estudando Vygotsky que percebemos que essa inferência obscura precisa ser encarada com mais atenção.

Em suma, seja a tríade ou qualquer outro instrumento que potencialize a aprendizagem da argumentação, deve-se ter sempre em mente que instrumentalizar não é educar. Aprendemos com Vygotsky que a linguagem é um instrumento que instigou o desenvolvimento cognitivo de nossa espécie; e a pergunta é: como empregá-la de modo a instigar o desenvolvimento de cada indivíduo? Isto é, de que adianta oferecer um instrumento a quem não sabe para que ele serve, não quer usá-lo e não quer aprender como usá-lo? De que adianta uma ferramenta para alguém que não se concebe artesão? De que adianta um violino para alguém que não vê magia na sinfonia cósmica? De que adianta uma lupa para quem não se reconhece detetive? Ela pode até ser usada, mas como um fim em si mesma, de forma muito limitada e aleatória; e não como um meio de promover uma investigação, não com o propósito de saber mais, de ser mais e emancipar-se dos limites impostos pelos mitos que aprisionam nossas próprias mentes.

Resumindo, ainda que nossa atuação se realizasse de forma dialógica, faltou diálogo em um momento crucial: no início do processo. Lembremos que, segundo Freire, o diálogo deve começar na escolha do conteúdo, pois é nesse diálogo inicial que percebemos as situações-limite que nos alienam.

Este é um deslize que já cometemos com a tríade. Vamos tentar remediá-lo.

\section{VII.4 - EVITANDO UM EQUÍVOCO}

Já havíamos sugerido a tríade como instrumento pedagógico (OLIVEIRA, ZANETIC; 2008). Como dissemos no último capítulo, este artigo foi escrito enquanto estávamos entorpecidos pelo canto da "sereia epistemológica", o que nos cegou para as questões ontológicas e axiológicas. Mas estas não podem ser esquecidas. A questão é: como aplicar a tríade sem que isto se torne mais uma tarefa repetitiva, "robotizada"?

Para que a tríade seja utilizada como uma forma de emancipação e não de opressão, ela deve ser percebida pelos educandos como tal. E isso só será possível se eles perceberem que a linguagem, da qual a tríade é pequeno exemplo, é instrumento de libertação ou de coerção; que a linguagem revela os valores e guia a postura de quem a enuncia. Se desejamos a justiça, o gesto verbal deve ser testemunha desse desejo. 
Fora disso, me emaranho na rede das contradições em que meu testemunho, inautêntico, perde eficácia. Torno-me tão falso quanto quem pretende estimular o clima democrático na escola por meios e caminhos autoritários. Tão fingido quanto quem diz combater o racismo mas, perguntado se conhece Madalena, diz: "Conheço-a. É negra mas é competente e decente." Jamais ouvi ninguém dizer que conhece Célia, que ela é loura, de olhos azuis, mas é competente e decente. No discurso perfilador de Madalena, negra, cabe a conjunção adversativa mas, no que contorna Célia, loura de olhos azuis, a conjunção adversativa é um não-senso. A compreensão do papel das conjunções que, ligando sentenças entre si, impregnam a relação que estabelecem de certo sentido, o de causalidade, falo porque recuso o silêncio, de adversidade, tentaram dominá-lo mas não conseguiram, o de finalidade, Pedro lutou para que ficasse clara a sua posição, o de integração, Pedro sabia que ela voltaria, não é suficiente para explicar o uso da adversativa mas na relação entre a sentença Madalena é negra e Madalena é competente e decente. A conjunção mas aí, implica um juízo falso, ideológico: sendo negra, espera-se que Madalena nem seja competente nem decente. Ao reconhecer-se, porém, sua decência e sua competência a conjunção mas se tornou indispensável. No caso de Célia, é um disparate que, sendo loura de olhos azuis não seja competente e decente. Daí o nãosenso da adversativa. A razão é ideológica e não gramatical (FREIRE, 1996, pp. 48:9).

Voltando a Bakhtin, a palavra, em um contexto, com um pretexto, é ideológica. O educando só perceberá a tríade como instrumento de emancipação se estiver convencido de que é preciso compreender a lógica científica para - se considerar necessário - dela se emancipar. A tríade deve ser apresentada como uma forma de elucidar um raciocínio científico para revelar-lhe o pretexto em determinado contexto.

Suponha uma propaganda televisiva. Um cientista de jaleco branco anuncia:

"Este creme dental é 30\% mais eficiente no combate às cáries do que o creme-x".

A lógica é:

Se este creme dental é 30\% mais eficiente, então ele é melhor do que o outro.

Portanto, compre-o.

O exemplo é banal, mas serve para elucidar o seguinte: agora aclaramos qual é a premissa da propaganda. E podemos questioná-la. O que quer dizer 30\% mais eficiente? Qual experimento foi realizado para determinar esse valor? Quais seus limites de validade? Assim, fica evidente que o propósito da suposta propaganda é utilizar o medo da matemática e os mitos que rodeiam a voz da ciência para fazer emergir na consciência do telespectador o mito: "quem sou eu para discutir com um cientista?".

Os escritores de ficção científica fazem algo parecido. Eles usam a voz da ciência para dar credibilidade à história. Utilizar a tríade para "linearizar" seus argumentos facilita a 
“desalienação". Principalmente em uma linha de raciocínio mais intrincada, essa estratégia ajuda-nos a nos desemaranhar. Isto é, ela pode alimentar um saudável ceticismo que nos permite rejeitar respeitosamente um absurdo ideológico que possivelmente teve sua origem em questões sociais.

....a história da ficção científica é resultado de duas tendências conflitantes. Uma delas, o potencial cognoscitivo, muito clara em todos os escritores importantes estudados (More, Luciano, Cyrano, Swift, Verne, Wells, Čapek, etc.), está unida ao surgimento de classes sociais subversivas, e às forças de produção e às cognições muito mais sutis que desencadearam. Não obstante, na ficção científica "de segunda" domina uma tendência ao escapismo mistificador que chega a apresentar-se inclusive nos mestres (a estática de More e de Swift, o positivismo de Verne), pois a constituem as limitações práticas e cognoscitivas de uma narrativa baseada na alienação de uma sociedade classista e, em especial, o estancamento de uma classe social anteriormente subversiva. Tal ocorreu com a burguesia quando, ao passar de guia de um avanço geral plebeu a exploradora ilhada da natureza e do povo, termina por considerar a produtividade e a cognição como meios de ganância, não como elementos fundamentais da criação, e regressa, obrigada por tal processo, a todo tipo de mistificações, desde o teísmo até a astrologia. $\mathrm{O}$ domínio de um enfoque cognoscitivo permite uma mescla fértil com o prazer lúdico do estranhamento. Pelo contrário, o predomínio de impulsos anticognoscitivos degrada o estranhamento, volvendo-o a um sensacionalismo formal e superficial, que primeiro causa um choque na burguesia, porém logo se une a ela, como já é óbvio em Verne e no Wells medíocre. No primeiro caso, estranhamento constitui um enfoque criador, sistema criador, um sistema [...] para explorar o novo; no segundo caso torna-se ópio para o povo: aquele que ignora que os ópios podem ser necessários para o alívio momentâneo de uma dor considerável, não deveria se esquecer do velho adágio corruptio optimi pessima [a corrupção dos melhores é a pior] (SUVIN, 1984, pp. 11:2, tradução livre).

À parte essa crítica voraz que já afirmamos não apreciar, o que devemos guardar dessa passagem é: seja a ciência, a ficção científica ou qualquer outro elemento de nossa cultura, um ponto é claro: quanto mais alienado, mais alienante (SUVIN, 1984, p. 50).

Por isso, antes de apresentar a tríade aos alunos, convém problematizar a própria lógica, entendida em sua definição mais elementar: estudo da fala, linguagem e argumento (STEPHENS, 2005, p. 37). Qual o pretexto da argumentação lógica em um contexto científico? Qual sua finalidade? Quais as consequências da argumentação lógica para a relação das pessoas com a ciência? Nesse ínterim, discute-se como a lógica se expressa na linguagem. Como, ao pensarmos e falarmos, utilizamos orações coordenadas ou subordinadas. Qual o objetivo do uso de cada tipo de oração. Mais uma vez, o trabalho congruente da equipe interdisciplinar se mostra necessário. Feito isso, aí sim faz sentido estudar um forno microondas ou apresentar a tríade como proposta de instrumento de análise da lógica de alguma obra (ou trecho dela). 
Em suma, ou cuida-se para falar com o educando sobre aquilo que lhe oprime, em "palavrasmundo" compartilhadas, ou a linguagem científica se tornará mera gíria indecifrável, mais uma verborragia incompreensível e opressora. Ou seja, para não ser mecanizada, a tríade deve ser tríademundo.

Dessa perspectiva, a ficção científica tem muito potencial pedagógico. Rabkin, por exemplo, considera uma iluminação a mudança drástica de perspectiva que o fantástico proporciona, uma vez que, durante a leitura, o novo contexto reconfigura a semântica da palavra, mostrando facetas que não eram percebidas.

Esta função do fantástico é educacional em sua raiz: ela leva da escuridão à luz, cria na mente uma reversão diametral e abre mundos novos e fantásticos (RABKIN, 1977, p. 25, tradução livre).

Ele argumenta que o estudo do fantástico fornece ferramentas para a análise da visão de mundo - e sua constelação de perspectivas componentes -, se desvendarmos aquilo que um indivíduo entende como "oposições operativas" (por exemplo: o contrário de homem é mulher ou menino?). Tal procedimento de exame da linguagem auxilia na localização dos tabus que perpassam uma cultura (RABKIN, 1977, p. 74).

Compreendendo a gramática científica e suas premissas relativas à ordenação do universo, podemos não só inserir-nos na ciência em maior profundidade, como dela nos emancipar. Aprender a lógica científica de nada vale se essa aprendizagem não implicar na mudança de postura frente ao mundo, se essa aprendizagem levar o jovem com sua lógica "infalível”, com seu raciocínio "superdesenvolvido", a oprimir arrogantemente outras pessoas porque ele acredita que aquilo que elas pensam é ilógico.

Cientes de que a linguagem oprime e conduz atitudes, aí sim podemos afirmar:

O principal 'fato' do século XX é o conceito de possibilidade ilimitada [...].

Dado este imenso continente de possibilidades, poucas literaturas parecem estar melhor equipadas para lidar com seus temas do que a ficção científica. Nenhuma outra forma de ficção tem o vocabulário de idéias e imagens necessário para abordar o presente, muito menos o futuro [...].

A ciência e a tecnologia multiplicam-se ao nosso redor. Em uma proporção cada vez maior, elas ditam as linguagens nas quais falamos e pensamos. $\mathrm{Ou}$ usamos essas linguagens ou permanecemos mudos (BALLARD, 1988, pp. $6: 7)$. 


\section{Capítulo VIII \\ Estudo de Caso - Alguns Exemplos Qualitativos \\ $O U$ \\ 'OUTROS BRASIS'}

- Acho que chegou a hora de uma pequena demonstração, meu tio. Há ocasiões em que uns poucos atos concretos têm mais valor que todas as palavras impressas nos belos livros da Grande Biblioteca do Recife.

Gerson Lodi-Ribeiro, 2006, p. 41.

Apresentaremos, agora, algumas aplicações da ficção científica com propósitos educacionais - experiências testadas na escola em que lecionamos. Dentre elas, divulgaremos produções ficcionais de cunho científico escritas por alguns educandos; indicando que, quando cognitivamente provocados, eles não demonstram ingenuidade.

Desde já, vale deixar claro que as atividades aqui relatadas foram precedentes à amálgama teórica costurada nos capítulos anteriores e, por isso, servirão apenas como indício circunstancial das potencialidades pedagógicas da ficção científica. 
Inicialmente, pretendíamos apresentar um trabalho exclusivamente teórico. Mudamos de ideia porquanto acreditamos que os exemplos abaixo indicam, ainda que de maneira vaga, que atividades envolvendo a ficção científica possuem um genuíno potencial pedagógico. Adiantemos que não criamos critérios de análise, categorias teóricas ou descritivas. As avaliações que realizaremos foram somente superficiais e qualitativas, sem a pretensão de corroborar a linha de raciocínio dos capítulos anteriores. Resolvemos apresentar algumas atividades apenas para buscar aqui e acolá pequenos indícios que reforcem aquilo que temos defendido - mesmo que elas não tenham sido formuladas de acordo com a metodologia freiriana e mesmo que algumas delas tenham sido praticadas no conjunto de uma educação muitas vezes bancária.

\section{VIII.1 - DESCREVENDO O CENÁRIO}

Em meados de 2008, passamos a lecionar na Escola Waldorf São Paulo. É uma escola particular, relativamente pequena, de classe média-alta, localizada no bairro Vila Olímpia na cidade de São Paulo. Por conta de uma política de bolsas e um projeto de integração social, existem alunos de outras classes econômicas - em uma porcentagem pequena, ainda que crescente. Ministramos aulas no $9^{\circ}$ ano e nas três salas do ensino médio, usualmente com quinze a vinte alunos, número também crescente - o que é bom, uma vez que a escola pode crescer mais, mas que, por outro lado, levou o corpo docente a manifestar um limite pedagógico de cerca de vinte e cinco alunos por sala.

A escola insere-se na Pedagogia Waldorf, idealizada por Rudolf Steiner. Usualmente, se identifica a metodologia da escola com uma postura mais artística, visto que a concepção de homem e conhecimento de Steiner parte de uma linha contemplativa, ligando-o a pensadores tais como Johann Wolfgang von Goethe e afastando-o da linha materialista e utilitarista que delineamos a partir de Francis Bacon. O método cognitivo de Goethe (2004) e Verdade e Ciência (1985) são obras de Steiner que indicam sua visão epistemológica. Sua perspectiva antroposófica de homem e universo é apresentada em Teosofia (2004) e A filosofia da liberdade (2000). Pedagogia, arte e moral (2008) e A arte da Educação, volumes 1 a 3 (2007; 2009; 1999), unem sua visão de homem, mundo e ciência, fornecendo uma base para sua concepção pedagógica.

Eventualmente, para quem quiser conhecer a pedagogia, o delicioso livro Filhos felizes na escola (2006) da psicóloga Helena Trevisan é ótima obra introdutória. O didático $A$ Pedagogia Waldorf (1990), de Rudolf Lanz, também. Em linhas gerais, existe uma 
preocupação com o ritmo dos alunos, biológica e espiritualmente falando, e por isso os primeiros minutos das aulas - inclusive as de ciências - se iniciam com atividades coletivas e artísticas. O horário das disciplinas, ao contrário do que usualmente acontece em várias escolas, não é organizado somente em torno de aulas simples ou duplas aleatoriamente distribuídas pela semana. Ele se organiza em épocas, isto é, períodos de três semanas onde o mesmo professor trabalha sua matéria diariamente, por cerca de 1 h30 - com um intuito de promover um mergulho mais profundo em poucas matérias por vez.

Nas aulas de ciências, especificamente, indica-se uma postura fenomenológica, apresentando experimentos antes de abstrações teóricas - o que permitiu que elaborássemos nossas aulas em uma sequência muito parecida com a do GREF (2002; 2005; 2007), realizando muitas experiências com material de baixo custo, além de aulas teóricas mais tradicionais, discussão de filmes biográficos e documentários, e até algumas aulas em que ousamos nos fantasiar de Aristóteles, Newton ou Einstein. E, é claro, os testes com a ficção científica que relataremos abaixo.

Dialogar sobre semelhanças e diferenças entre as ideias de Steiner e as do materialismo em que nos alicerçamos nos capítulos anteriores, ainda que seja uma tarefa factível, tomaria muito tempo e espaço ${ }^{76}$. Assim, prosseguiremos até o final da dissertação com a linha de raciocínio precedente, postergando uma leitura steineriana dessas atividades para uma outra oportunidade.

Quanto à diversidade cultural, de acordo com levantamentos que vimos realizando anualmente, entrevemos classes muito heterogêneas. Existem tanto alunos bons leitores quanto alunos que não gostam de ler; os gêneros apreciados incluem tanto romances policiais quanto terror; biografias a poesias; não ficção a ficção. Em relação ao gosto musical, cinematográfico e televisivo, verificamos variedade semelhante - o que talvez seja uma consequência da própria diversidade cultural da cidade de São Paulo. Durante as pesquisas, que os alunos respondem no papel e depois exteriorizam para o grupo, é difícil conter os ânimos de alguns que logo resolvem julgar o gosto distinto dos outros, confundindo diferenciação com hierarquia. O propósito de fazer a pesquisa anualmente é possibilitar que os jovens acompanhem eventuais mudanças na seleção das obras que apreciam (dado

\footnotetext{
${ }^{76}$ Academicamente começam a despontar trabalhos que relacionam Freire e Steiner, vide Bach Jr. (2007). Segundo consta em seu curriculum lattes, acessado em 10 de outubro de 2010, seu doutorado, ainda em andamento sob orientação da Profa. Dra. Tania Stoltz na Universidade Federal do Paraná, intitula-se justamente: A Pedagogia Waldorf como educação para a liberdade: reflexões a partir de um possível diálogo entre Paulo Freire e Rudolf Steiner.
} 
interessante: a ficção científica, após a realização de alguns trabalhos de leitura que propomos todo ano, passou a aparecer nessas pesquisas).

\section{VIII.2 - ATIVIDADE 1: O Projeto CiÊNCIA E LITERATURA}

O mote para pensarmos tal projeto foi a percepção de que muitos alunos não se manifestavam durante nossas aulas (podemos afirmar com tranquilidade que isso não era consequência de uma frieza em nossas relações - o número reduzido de alunos facilita a postura dialógica). Após um tempo, percebemos que, em muitas de nossas aulas, estávamos dando respostas a perguntas que eles sequer haviam se feito. Hoje notamos onde estava o equívoco: apesar de a relação ser dialógica, o conteúdo não o era, pois ele não representava situações-limite impregnadas em nossas mentes.

De qualquer forma, o que importa aqui é que daquela percepção nasceu o Projeto Ficção Científica, com o objetivo principal de instigar-lhes a fazer perguntas. Como o tamanho de nossa biblioteca particular permitia emprestar livros para vários estudantes, instituímos o seguinte: cada aluno iria ler um livro e formular dez perguntas quaisquer baseadas na narrativa. Além disso, deveria ser informada a página que inspirou cada questão. Dentre as perguntas criadas, cada aluno indicaria as duas que mais lhes intrigaram, e diria o porquê de tal escolha. Finalizando o trabalho, eles diriam se gostaram ou não da história e por quê. Como muitos não sabiam o que ler, passamos duas aulas contando resumos de algumas histórias. O resultado foi bastante heterogêneo. Muitos estudantes criaram indagações distantes dos trechos tecno-científicos dos livros; o que obviamente não quer dizer que as perguntas eram ilógicas. Vejamos poucos exemplos.

Sobre A Máquina do Tempo de H. G. Wells um jovem questionou:

Como os Elóis, que tanto temem os Morloques, algum dia fizeram deles seus 'escravos'?

E se a temperatura é mais quente do que hoje, por que as pessoas são tão brancas?

Um outro, que leu este mesmo livro, teve uma dúvida conceitual, e quis saber:

O que é a quarta dimensão? (não sabia o que é uma quarta dimensão então resolvi pesquisar para me intrigar mais).

Um aluno, que leu $O$ Guia do Mochileiro das Galáxias de D. Adams, com uma expressão de felicidade veio nos dizer que havia encontrado um erro lógico no livro: 
Como [o planeta] Magrathea é vermelho do espaço sendo que sua superfície é cinza?

Após ler Frankenstein de Mary Shelley, um outro indagou:

Como a criatura já sabia realizar certas ações quando lhe foi dado vida?

Apenas uma aluna afirmou: "as perguntas que fiz, tentei relaciona-las com a física, mesmo que só um pouco". Vejamos seu esforço. Ela leu A volta ao mundo em 80 dias de J. Verne.

Por que Phileas Fogg criou um raciocínio de uma órbita sem se preocupar com os asteróides que gravitavam?

Por que as perturbações produzidas pelo astro seriam mais difíceis de calcular do que Urano?

Ainda que compreensíveis, as questões soam confusas. Fica difícil saber se ela não entendeu aquilo que lia ou se lhe faltou didática na hora de expressar as perguntas.

Outra aluna, que leu Viagem ao redor da Lua, também de Verne, disse:

Pg. $59 \rightarrow$ Nessa parte do livro conta-se que alguns povos antigos acreditavam que a lua era um cometa. Qual é a prova, segundo Barbicane, de que essa idéia é incorreta?

Ela comenta sua questão:

A pergunta 2 trata sobre a questão da lua já ter sido considerada um cometa por povos antigos, e a prova de que essa informação não é correta, pelo simples fato da "lua não ter conservado vestígios do invólucro gasoso que sempre acompanha os cometas", essa 'prova' foi dita por Barbicane, (o presidente da excursão). É claro que hoje em dia há muitas explicações e estudos a respeito da lua, e já se sabe por diversas razões o fato da lua não ser um cometa, e quais as diferenças entre ambos!

Cremos que esses exemplos são suficientes para esboçarmos algumas análises.

Em primeiro lugar, fica evidente que, ao menos nessas perguntas selecionadas, existiu um esforço dos estudantes para entender o que liam. Inspirados em Freire, diríamos que eles realmente buscaram saber mais. Como, em alguns dias, alguns vinham nos contar empolgados algo que haviam lido, podemos supor que o escritor, nesses casos, era o sujeito mais capaz de que nos fala Vygostsky. Ou seja, em uma relação interpessoal em que existe o desejo de saber, os alunos, ao imitarem a maneira de pensar desses escritores - sem que essa imitação fosse meramente mecânica -, estavam genuinamente aprendendo alguns jogos da linguagem científica, possivelmente transpondo uma zona de desenvolvimento proximal.

Porém, não podemos deixar de apontar outra perspectiva. Ao clonar a maneira científica de pensar, eles incorporavam a ideologia subentendida nesse grafoleto, vide a 
alegria do aluno felicíssimo ao descobrir um erro em uma história; ou, a aluna que afirma: "é claro que hoje em dia há muitas explicações e estudos a respeito da lua, e já se sabe por diversas razões o fato....". Nessas frases, o sujeito impessoal traz implícito o artifício de supor uma verdade imparcial sabida por todos. Em outras palavras, a imersão nas narrativas acabou ensinando certa lógica aprisionando-os a ela, e não os libertando dela. E, como não realizamos uma problematização crítica do não-dito subentendido nas histórias, não permitimos um distanciamento ideológico. Mantendo essa postura, corremos o risco de levar os estudantes a assumirem a voz da ciência sempre que quiserem ocupar o lugar de uma instituição que, dependendo da forma que é admitida, pode ser opressora.

Algumas questões mais existenciais também apareceram. Uma aluna leu Admirável Mundo Novo de A. Huxley, e selecionou as duas questões que se seguem. Os comentários sobre as perguntas escolhidas são muito reveladores.

$\rightarrow$ Por qual razão eles querem ensinar as crianças durante o sono?

Escolhi essa pergunta porque foi algo que me chocou muito. Não gostei nem um pouco deles ensinarem as crianças através do sono-ensino. Não concordo com isso. Não acho que a criança deve acordar falando o que ouviu a noite inteira. Acho que a criança não sabe realmente do que ela está falando e do que se trata, pois ela decorou literalmente.

$\rightarrow$ "Não deixe para fazer amanhã o que se pode gozar hoje". Essa frase tem alguma ligação com atualmente? Por quê? Justifique sua resposta.

Escolhi essa pergunta, pois achei que tem realmente uma ligação com os dias atuais. Quando li essa frase, me espantei e pensei: "nossa isso cabe, acho eu, nos dias de hoje". No mundo em que vivemos é melhor realmente fazermos as coisas hoje e gozar delas do que deixar para amanhã, que talvez não consigamos fazê-las.

Nesse mundo em que você sai de casa com medo de ser assaltado, morto, levar uma bala perdida, ser atropelado... e tantas coisas mais, que devemos fazer todos os dias coisas que gostamos, pois nunca se sabe o que vai acontecer amanhã, ou depois e depois.

O primeiro pensamento que nos veio à mente quando lemos tais comentários foi uma sensação de que raramente vemos os estudantes se expressarem dessa forma em nossas aulas marcadamente conceituais, internalistas. Isso nos mostrou um lado desse projeto não premeditado, mas importante: ele é um espaço para os estudantes explicitarem o que pensam, defenderem o que acreditam. Vários fizeram isso, principalmente os que leram distopias e utopias. Para nós, isso foi muito importante, pois passamos a atentar mais a algumas facetas dos estudantes, a suas formas de pensar o mundo, a suas ideologias.

Uma outra parte do trabalho - dizer se gostou ou não do livro e o porquê disso trouxe muitas informações preciosas. Um estudante, que leu $O$ guia do..., escreveu: 
Eu escolhi o livro por indicações de amigos, quando li, percebi que é muito engraçado e irônico, e que ler pode não ser tão chato.

Um outro que leu $O$ Homem Invisível de H. G. Wells afirmou:

Gostei de ter lido esse livro. Não somente por ter gostado da história mas sim porque descobri os livros de ficção científica.

Por outro lado, outras frases levantaram questões que nos levaram a rever o projeto. A aluna que leu $O$ admirável..., citada acima, escreveu:

Não gostei muito do livro. Achei ele muito parado e me dava sono. Algumas horas interessantes outras não.

Acho que não gostei muito do livro por causa que não gosto de ficção científica.

Quanto à primeira parte da resposta, podemos dizer que a pesquisa cultural inicial foi de grande importância para compreendê-la. Esta estudante havia enumerado como filmes e livros preferidos histórias de amor e comédias românticas. Não é de se estranhar que ela tenha se impressionado com as especulações de Aldous Huxley a ponto de se revoltar com o sonoensino. Ainda assim, não podemos afirmar que a leitura foi uma experiência perdida. Certamente a distopia de Huxley deve ter servido ao seu propósito quando ela vislumbrou uma outra forma de ensino e, comparando-a com o que acreditava, achou aquilo abominável.

Quanto à segunda parte, ela nos levou a pensar um pouco mais sobre dois fatos. Primeiro: nem todo mundo gosta de ficção científica. Segundo: nem todo mundo gosta de ler. Entretanto, como certos exemplos nos mostravam que alguns alunos se deleitaram com a experiência, resolvemos continuar com o projeto, porém ampliando-o: ele passou a se chamar Projeto Ciência e Literatura, abrangendo romances policiais (desde A. Conan Doyle até Agatha Christie), peças teatrais (como Os físicos de F. Dürrenmatt; $O$ caso Oppenheimer de H. Kipphardt; e, Vida de Galileu de B. Brecht), poesia (Augusto dos Anjos, André Carneiro...), etc., desde que relacionados com a ciência. Inclusive, com o sucesso do projeto, requisitamos uma verba para a escola com o objetivo de comprar 54 livros previamente selecionados. Uma família prontamente disponibilizou o valor requisitado e, por conta de muitas viagens a sebos - onde garimpamos muitos livros mais baratos do que o orçamento inicial - hoje a biblioteca da escola possui 94 obras relacionadas ao projeto. 


\section{VIII.3 - Atividade 2: UM Conto E A Tríade Se-Então-Portanto}

Em 2009, ao abordar as Leis de Newton e inserir o conceito de força no penúltimo ano do colegial, resolvemos utilizar o conto $O$ cair da noite $e^{77}$, pois ele faz uso explícito da formulação da força gravitacional em sua história (ASIMOV, 1981, p. 18).

O conto tem mais de trinta páginas. Todavia, a estruturação das aulas facilitava nosso serviço, uma vez que passaríamos três semanas trabalhando diariamente na mesma sala. Líamos duas páginas por dia, nos primeiros dez minutos de aula. No dia seguinte, antes de nova leitura, pedíamos que alguém recapitulasse a história. Em alguns dias, finda a leitura, ocorria uma discussão espontânea sobre algum assunto narrado. Apesar de ficarmos preocupados com a duração desses debates por conta das demais atividades que havíamos preparado para a aula, não os interrompíamos levianamente.

Algo que facilitou muito a escolha dos pontos onde pausaríamos a leitura de um dia para outro foi a estrutura do conto - são muitas ações paralelas e muitos momentos de suspense. Inclusive, no último dia, abusamos dos artifícios para aumentar a tensão: sussurramos quando oportuno, criamos o clima sutilmente para que um susto acompanhasse um grito de uma personagem, etc. Quando lemos a última - e aterrorizante - linha do conto, o silêncio e a expectativa na sala eram ensurdecedores.

Após uma breve discussão sobre o final do conto, solicitamos, de tarefa, quatro atividades. $\mathbf{1}^{\text {a }}$ : baseados em trechos selecionados, reorganizá-los com base na tríade se-entãoportanto (escrevemos alguns exemplos). $\mathbf{2}^{\mathbf{a}}$ : recontar a história, numa tentativa de testar a própria memória - foram três semanas de leitura... $\mathbf{3}^{\mathbf{a}}$ : dizer se gostou ou não do conto e por quê. $4^{\mathrm{a}}$ : informar o que mudariam no conto se fossem reescrevê-lo.

Analisemos somente a primeira atividade. Uma frase que pedimos que os alunos reorganizassem por meio da tríade foi a seguinte.

[Sheerin explica para Theremon o que o Livro das Revelações dos Cultistas fala sobre o planeta Lagash].

- Exatamente - disse Sheerin com satisfação. - Os Cultistas afirmam que a cada período de duzentos e cinqüenta anos Lagash entra em uma imensa

\footnotetext{
${ }^{77}$ Sinopse: um planeta chamado Lagash possui seis sóis e, por isso, não conhece noite. Contudo, de acordo com os últimos cálculos realizados em um Observatório, uma perturbação na órbita do planeta indica a existência de um objeto que não possui luz própria girando ao redor de Lagash (essa lua não é vista por conta do excesso de luminosidade dos seis sóis). E se prevê que, em certo dia, quando cinco sóis estarão do outro lado do planeta, o único sol no céu - Beta - será eclipsado por tal lua. Essa escuridão era prevista no livro dos Cultistas, um tipo de religião do planeta. $\mathrm{O}$ conto se desenvolve em torno desse medo da chegada da Escuridão e das Estrelas. Os principais personagens são: Aton, o diretor do observatório cujo prestígio depende da confirmação do eclipse; Theremon, um jornalista que questiona os cálculos de Aton; e Sheerin, um psicólogo com várias teorias sobre o medo da escuridão e sobre o universo.
} 
caverna, de forma que todos os sóis desaparecem e uma completa escuridão envolve o mundo. Acrescentam que coisas chamadas Estrelas aparecem, privam os homens de sua alma e os transformam em animais irracionais que destroem a civilização que eles próprios criaram (ASIMOV, 1981, p. 17).

Vejamos como duas alunas reformularam a essência do trecho acima:

Se os sóis desaparecem, então as estrelas aparecem, portanto os homens viram animais irracionais.

Se as estrelas aparecem então tudo se torna escuro, portanto todos os sóis desaparecem.

De formas diferentes, elas conseguiram perceber quais orações deveriam ser concatenadas. A segunda, contudo, inverteu causa e efeito.

Outro trecho que pedimos que eles rearquitetassem foi:

[Sheerin explica a Theremon o porquê de a cidade ser queimada quando chega a Escuridão].

- Qual é o único meio de conseguir luz excluindo-se o sol?

- Como posso saber?

Os dois estavam de pé face a face, nariz contra nariz.

Sheerin disse: - O senhor queima alguma coisa. Já viu um incêndio na floresta? Já acampou alguma vez e cozinhou com fogo de lenha? O calor não é a única coisa que nos vem da queima da madeira, você sabe. Ela também fornece luz, todos sabem disso. Quando há escuridão, as pessoas querem luz e passam a procurá-la.

- E queimam madeira?

- Queimam tudo que podem. Desejam luz. Quando precisam queimar alguma coisa e não têm madeira à mão, queimam o que estiver mais perto. Querem ter luz - e cada centro habitado se desfaz em chamas! (ASIMOV, 1981, pp. 23:4).

Vejamos o que alguns alunos reescreveram.

Se o fogo é o único meio que as pessoas terão para obter luz, então elas queimarão tudo que for possível, portanto destruirão a cidade.

Se o fogo produz luz e os homens estão no escuro, então vão queimar alguma coisa, portanto vão destruir tudo.

Se o único meio de conseguir luz excluindo-se o Sol então procuramos fogo, portanto, cada centro habitado se desfaz em chamas.

Se com a queima da madeira fornece luz, então quando falta luz as pessoas querem luz, portanto elas queimam mais do que pode.

Todos utilizaram mais de três verbos e, portanto, mais de três orações. O que não anula suas lógicas, apenas nubla-as. Todos concatenam corretamente causa e efeito, mas seria possível lapidar o resultado. Porém, supomos que a culpa dessa dificuldade é nossa, uma vez 
que selecionamos um trecho muito grande, e os alunos tentaram rearranjar muitas informações no mesmo período.

Apontemos apenas mais uma frase que pedimos que eles rearranjassem.

[Beenay explica uma de suas teorias: a possibilidade de existência de planetas que possuíssem apenas um sol; e especula sobre a vida em um desses planetas].

- Certamente - continuou Beenay - existe apenas uma dificuldade: a vida seria impossível nesse planeta. Ele não teria suficiente luz e calor. E se girasse, haveria total Escuridão durante a metade de cada dia. Você não poderia esperar que a vida - fundamentalmente dependente da luz - se desenvolvesse nessas condições (ASIMOV, 1981, p. 36).

Notemos que Asimov explica de forma lógica algo que sabemos ser errado, pois nosso mundo é assim. Isso é um ingrediente que pode confundir os alunos, dificultando a reestruturação.

Se o planeta possuísse apenas um Sol, então haveria metade do dia escuro e metade iluminado, portanto seria improvável o desenvolvimento de vida nessas condições.

Se um planeta tivesse apenas um Sol, então não teria luz e calor suficiente, portanto não haveria vida com dependência de luz.

Se existe apenas uma dificuldade, então a vida seria impossível nesse planeta, não teria calor suficiente e se girasse haveria escuridão durante metade de cada dia, portanto, não poderia esperar que a vida se desenvolvesse nessas condições.

Se a vida fosse impossível nesse planeta, então é porque não haveria Sol e calor para todos, ou se girasse, haveria dia/noite, portanto não teria como haver um desenvolvimento.

Se a vida depende inteiramente de luz, então não há como viver metade de um dia com escuridão, portanto não há como haver um planeta com um só Sol.

Os dois primeiros exemplos estruturam-se com três verbos, e com causa e efeito devidamente colocados. A terceira tentativa, menos concisa que as outras, parece menos coerente já que inverte causa e consequência em meio a muitas orações. A quarta também está confusa, pois foi organizada em torno de sete verbos. Ainda assim, parece-nos que tal estudante entendeu como se dá o dia e a noite em um planeta girante. Na última tentativa, verificamos uma inversão interessante na direção da causalidade - ao invés de algo no sentido "com apenas um Sol não há vida no planeta" quem perde a possibilidade de existência é o planeta de um só Sol, e não a vida fotofílica. 
Em suma, verificamos que alguns alunos conseguiam estabelecer períodos coerentes para a maioria dos dez trechos que havíamos selecionado. Por outro lado, teve aluno que desistiu no quinto ou sexto trecho e vários outros sequer realizaram a tarefa.

Primeira conclusão: devemos selecionar melhor os trechos, e quem sabe expô-los em um grau crescente de dificuldade, para facilitar o desenvolvimento da atividade pelos estudantes. Segunda conclusão: muitos alunos conseguiram desenvolver muito bem os enunciados nos trechos referentes ao se-então; contudo, a frase iniciada pela palavra portanto parecia sempre dificultar a estruturação de seus raciocínios. Talvez fosse mais interessante iniciar somente com a estrutura se-então e, depois de algumas atividades, expandir para a construção de períodos com o portanto.

A conclusão mais importante é a que conseguimos realizar hoje, após a leitura de Freire: muitos alunos não fizeram a tarefa, outros realizaram com certo desleixo e alguns desistiram no meio dela porque, como dissemos no último capítulo, provavelmente demos a lupa a quem não queria investigar. Em outras palavras, elaboramos a atividade preocupados com o desenvolvimento cognitivo dos estudantes, mas esquecemos de nos preocupar com suas liberdades de escolha. Isto é, aplicamos a ficção científica acreditando que ela seria suficiente para cativá-los, o que não ocorreu com todos visto que a atividade não problematizava o conto para problematizar nossas mentes.

Permitam-nos expor aqui apenas mais uma atividade que ensaiamos na escola.

\section{VIII.4 - Atividade 3: Contos Criados Pelos Próprios Estudantes}

Uma outra experiência que tivemos na escola foi muito gratificante. Pouco depois do que foi narrado acima, após finalizar o assunto energia na mesma sala, quatro alunos deixaram de realizar algumas atividades e, para recuperar a nota, receberam um conjunto de exercícios para resolver - tudo bem tradicional. Entretanto, por iniciativa própria, dois deles pediram para escrever, no lugar da resolução da lista, um conto de ficção científica. Por coerência, estendemos a proposta aos outros dois estudantes que, para nossa surpresa, recusaram-na e decidiram seguir com a lista. Em vez de interpretar essa surpresa, permitamnos deixar a palavra com a "ficção" de Ursula K. Le Guin.

Quando lhe explicaram o sistema de exames, ele ficou estarrecido; não podia imaginar maior coibição ao desejo natural de aprender do que um modelo que os entulhava de informações para serem expelidas por solicitação. No começo ele se recusou a dar notas ou provas, mas isso deixou os administradores da Universidade tão preocupados que ele, não desejando ser 
descortês com seus anfitriões, cedeu. Pediu aos estudantes que escrevessem um trabalho sobre qualquer problema de física que lhes interessasse e disselhes que daria a todos a maior nota, para que os burocratas tivessem o que escrever em seus formulários e listas. Para sua surpresa, uma série de estudantes foi até ele reclamar. Queriam que ele desse os problemas, formulasse as devidas questões; não queriam pensar sobre questões, mas escrever as respostas que tinham aprendido. E alguns protestaram com veemência contra sua intenção de dar a todos a mesma nota. Como os bons alunos poderiam ser distinguidos dos negligentes? De que adiantaria então estudar tanto? Se nenhuma distinção competitiva fosse feita, dava no mesmo não se fazer nada.

- Sim, claro - respondeu Shevek, perturbado. - Se não querem fazer o trabalho, não devem fazê-lo.

E eles se foram, ainda intranqüilos, mas gentis. Eram rapazes agradáveis, de modos francos e civilizados. As leituras de Shevek em história urrasti levaram-no a decidir que de fato eles eram, embora a palavra fosse então raramente usada, aristocratas. Nos tempos de feudalismo, a aristocracia enviava seus filhos para a universidade, conferindo superioridade à instituição. Agora ocorria o inverso: a universidade conferia superioridade ao homem. Eles contaram a Shevek com orgulho que a competição para bolsas de estudo da Universidade de Ieu Eun tornava-se a cada ano mais renhida, provando o espírito democrático da instituição. Shevek comentou:

- Vocês põem outra fechadura na porta e chamam a isso de democracia.

Ele gostava de seus alunos inteligentes e gentis, mas não sentia muito afeto por nenhum deles. Faziam planos para suas carreiras de cientistas industriais ou acadêmicos e o que aprendiam com ele só significava para eles um meio de alcançar esse objetivo, o sucesso de suas carreiras. Ou eles tinham, ou então negavam a importância, qualquer outra coisa que ele porventura thes oferecesse (LE GUIN, 1978, pp. 99:100).

Extrapolamos um pouco a transcrição até chegar a uma crítica à universidade, mas acreditamos que valia a oportunidade. "Sem a competição, de que adiantaria estudar tanto?" realmente fica difícil, no meio de tanta hierarquia meritocrática, não passar a acreditar que o objetivo do estudo é se sair melhor do que os outros (para concorrer por um emprego ou o que quer que seja), em vez de enfrentar nossa própria ignorância. Fica difícil relacionar o significado da aprendizagem à condição humana.

Enfim, fato é que dois alunos escreveram contos, e dois não. A única restrição: a ficção que eles criariam deveria abordar, em algum momento, o assunto que havíamos acabado de estudar - conservação de energia.

Este primeiro conto, reproduzido na íntegra, foi elaborado por Ivan Marquesi Lerner e recebemo-lo a 27 de abril de 2009.

Os dois homens estavam sentados em duas poltronas numa sala pequena. A sala era pobremente mobiliada e não tinha janelas, além das duas poltronas tinha apenas uma mesinha no centro com alguns aperitivos e bebidas. O silêncio reinava enquanto os homens olhavam para o chão 
com seus copos cheios intocados. Um deles era ruivo e estava com um macacão de dormir apenas, e expressão permanentemente dura, o outro era mais baixo, com o cabelo grisalho e com uma expressão também preocupada. O silêncio foi rompido pelo som da porta se abrindo, de fora veio um homem novo, aparentava uns trinta anos e parecia até feliz, mas muito nervoso e eufórico, estava enfiado em um terno meio velho. Naqueles tempos eram raríssimas as ocasiões em que se necessitava de uma roupa melhor do que a roupa bege padrão que se usava na estação.

- Faltam vinte e quatro horas! - comentou eufórico.

Os outros dois o olharam irritados. O grupo estava com os nervos aos frangalhos e provavelmente não conseguiriam dormir aquela noite.

- Pelo amor de deus homem, pare com isso. Até parece que não sabe pelo que vamos passar daqui a vinte e quatro horas! Isso não é mais treinamento nem vídeo-game ou seus livros de ficção científica, isso é real! - falou o ruivo.

O jovem continuou parecendo ignorá-lo:

- Já ligaram o densificador e atingirão aproximadamente em vinte horas a densidade crítica para abrir o buraco negro! Depois levaremos mais duas horas até a entrada.

- E por que você está tão confiante? Tudo pode dar errado: a blindagem da nave pode não ser suficiente, podemos morrer pela velocidade... Não fazemos a mínima ideia do que poderá acontecer depois de entrarmos no horizonte de eventos. A chance de dar certo é tão pequena que mesmo com o computador arredondando na trilhonésima casa decimal a chance continua incalculavelmente baixa. - disse o ruivo novamente.

A essa altura o mais jovem já tinha retirado mais uma poltrona da parede e se sentado bebendo confortavelmente. Então o velho que até agora estava quieto falou:

- Mesmo com todos esses perigos eu ainda queria ir com vocês. Pena que fui afastado do projeto até mesmo antes de lançarem vocês para o espaço. Me deixaram vir para presenciar o lançamento mas até agora todas essas coisas de que vocês estão falando são como nada pra mim pois a missão é confidencial.

- Agora que toda essa diplomacia de imprensa acabou já podemos falar tranquilamente pelas próximas horas. É assim: Como você sabe, um buraco negro é uma quantidade de massa com uma densidade absurda, e como o espaço-tempo se curva com a massa, essa densidade, chamada de densidade crítica, cria um rombo no espaço-tempo, causando o buraco negro. Há suposições que hoje já são mais fundamentadas, sobre os buracos de minhoca. Esses são ligações entre dois pontos do espaço ou até de dois universos paralelos que podem ser causados por uma gravidade muito alta ocasionando na junção desses dois pontos. Nós criaremos esse buraco negro utilizando a energia que conseguimos captar do sol, e entraremos nele com uma nave que tem uma blindagem de um material suficientemente resistente e veremos o que acontecerá. Como o interior do buraco negro é uma singularidade, e a energia se conserva por uma simetria no tempo, talvez possam acontecer coisas tão imprevistas que talvez o buraco negro não se desintegre e acabe com o sol, ou talvez nós simplesmente não consigamos manter o buraco negro lá até entrarmos. O densificador manterá a massa prestes a atingir a densidade crítica e quando formos entrar o buraco negro se abrirá. Agora é melhor você sair junto com os outros para a estação extrassolar para ver o lançamento.

- Está bem. Boa sorte para vocês.

Depois de despedidas calorosas, o mais velho foi para a estação extrassolar e começaram os preparativos para o lançamento. Vinte horas depois a nave começava a acelerar para a velocidade necessária enquanto o densificador esperava para atingir a densidade crítica.

Já no caminho de volta para a Terra a estação extrassolar abre as janelas com filtros solares para ver o lançamento. A estação intrassolar se desintegraria após o mesmo, e inicia-se a contagem regressiva. Cinco, a nave atinge a velocidade necessária, quatro, o densificador inicia a densificação final, três, dois, um. Por um breve instante, na estação extrassolar, com tudo silencioso, uma voz fala: "zero". Escuridão. O sol se apaga. Toda sua energia é direcionada ao buraco negro dentro de si destruindo a estação intrassolar e restando apenas o invólucro que impede o sol de ser sugado para dentro de si mesmo. O buraco negro se desfaz e numa explosão gigantesca o sol renasce e, por um breve momento, a Terra ficará na escuridão. Esta lançada.

A estação extrassolar é impulsionada em direção à Terra pela enorme força do vento solar e começa a nova era. 
Como este aluno partiu da conservação de energia e chegou a pensar em buraconegro nós não sabemos. Se não nos falha a memória, em meio a uma aula bem tradicional sobre energia potencial gravitacional mencionamos, por conta de uma pergunta, essas fissuras cósmicas.

Antes de tecer mais comentários, convém já reproduzir o conto do outro aluno - cujo nome, por falta de uma autorização expressa, não será divulgado. Ele nos foi entregue na mesma data.

\section{O Projeto}

No ano de 2123 o Dr. Abganel e o renomado astrônomo Ryan, cujos títulos não mais importam devido ao fato que ambos e outros estudiosos encontravam-se em uma base do Ártico, a qual aparentava ser uma última colônia da raça humana. O planeta Terra havia sido abalado por uma série de fenômenos catastróficos em cadeia que foram denominados de "Cadeia Armagedom" deixando a maior parte da Terra inabitável. Em A-21 (nome da base em que se encontravam), descobriram previamente os eventos e os responsáveis da base, que depois vieram a formar uma espécie de Conselho, contataram autoridades que com pouco tempo tentam manter em sigilo a informação e começaram a evacuar alguns para o Ártico e o Antártico que segundo as previsões estariam isentos do C.A..

Por motivos desconhecidos a informação acabou nas mãos da imprensa que espalhou a notícia que gerou um caos maior do que o da crise de 2098, silenciado subitamente em questão de horas pelo C.A.. As previsões estavam incorretas e o Antártico e grande parte do Ártico foram brutalmente atingidos. A-21 passou por um período difícil por 2 meses até que Hirashi, um químico chinês conseguiu resolver os problemas e atingir uma certa estabilidade para os que sobreviveram fornecendo matéria e energia através do Sol que iluminava a região por 6 meses. Daí o problema, em 4 meses tal fonte não existiria mais e entrariam em 6 meses de escuridão.

O Conselho diante da situação juntou todos os remanescentes e procurando por uma solução começaram diversas pesquisas e estudos que tinham matéria e energia suficiente até o fim do verão, entre elas a do Dr. Abganel.

Ryan estava trabalhando em um projeto junto de outros que pretendia criar baterias de energia suficiente para o período e matéria, já que a matéria do projeto de Hirashi era de um tipo especial e não podia ser armazenada do modo convencional. Ele recebera por 17 dias, todos os dias um convite de Abganel para que participar de seu projeto, mas apesar de não estar usando seus conhecimentos astronômicos, se sentia entusiasmado pelo projeto, estava trabalhando com um dos cientistas que admirava e para completar o Dr. Abganel tinha a fama de ser "exótico". Naquele dia ele recebera o convite de manhã mas desta vez notou algo diferente dos outros 17 , desta vez ele dizia:

"Caro Ryan Kirk,

O convido novamente para participar de meu projeto, sei que talvez o recuse novamente, mas digo se antemão que há algo nele que deve lhe interessar.

PS: Buraco Negro

Abganel"

Ryan se sentiu tentado, apesar dos motivos já citados, não estava usando seu potencial, e mais ainda, se havia algo neste universo que intrigava eram os buracos negros, por isso foi consultar Abganel para ver o que se tratava. Lá foi recebido por Abganel que disse:

- Entre meu caro, vejo que desta vez se interessou pelo meu convite, sente-se. por educação:

Ryan já o conhecia mas nunca tiveram uma conversação mais do que uma simplesmente

- O Dr. Citou buracos negros em sua mensagem e é só por isso que venho aqui, peço que seja breve e racional. 
Abganel: - Por favor, me chame de Abganel, o doutor é apenas uma conseqüência de meus estudos, mas como pediu não desperdiçarei seu tempo e serei direto, sei que se interessa por buracos negros e portanto conclui que deve se interessar pelo inverso de tal fenômeno.

Ryan: - Se explique.

Abganel: - Acredito eu que seja possível criar um buraco claro ou branco, como preferir e acredito que ocorra naturalmente mas é o inverso do que conhecemos que é visível, como é oposto dele seria mais que natural que não fosse e portanto nunca relatado.

Ryan: - Faz sentido mas mesmo se conseguíssemos tal feito extremamente notável não conseguiríamos controlá-lo...

Abganel: - Mas não acha que valeria a pena tentar?

Ryan: - Sim mas...

Abganel: - Então está decidido, não acha melhor falar com os que estavam trabalhando em seu antigo projeto? Não é justo com eles que vá entrando assim em projetos meu caro.

Ryan: - ...

Abganel: - Começaremos amanhã vou falar com Peter e Saduj, meus ajudantes nos encontraremos as 8:00 no L-13 certo?

Ryan saindo diz para si mesmo: - E eu tenho escolha?

Abganel responde: - É dizem que é até meio chato eu ter bons ouvidos.

Ryan saiu envergonhado e pensa sobre a conversa que acabara de ter, e pensando no assunto, seus parceiros estavam tendo um progresso bom e haviam ainda outros projetos, portanto, sua ação de interesse pelo desconhecido ele aceitou a oferta de Abganel.

No outro dia conheceu os dois ajudantes que tinham um alto conhecimento e habilidades mecânicas inacreditáveis, além de serem extremamente dedicados e idolatrarem Abganel. Ryan, o Dr. e os ajudantes e outros elementos foram chamados durante o processo criaram o projeto que possibilitaria a criação do buraco branco, a máquina foi chamada de GBB. Por longos dias que se tornaram semanas eles trabalharam dia e noite quase sem descanso, especialmente Saduj que era de longe o maior admirador de Abganel. Até que conseguiram finalizar o GBB. Agora precisavam apresentá-lo ao Conselho. Marcada a audiência se prepararam para apresentar sua criação:

O diretor do Conselho, William: - está iniciada a primeira sessão de apresentação de projeto, peço ao responsável dele se apresente. do projeto.

Abganel: - Este seria eu, apesar de reconhecer que não sou o responsável pela totalidade

William: - Poderia relatar sobre ele?

Abganel: - É claro. Nós desenvolvemos uma máquina que pode gerar um buraco branco que geraria segundo os cálculos forneceria de forma controlada energia e matéria que possibilita...

William: - Segundo os cálculos?

Abganel: Bom, não é $100 \%$ certo, mas mes...

dizer?

William: - E você arriscaria a vida dos últimos humanos nos seus cálculos, é isto que quer

Abganel: - Há uma chance é isso que temos de considerar e estamos chegando ao fim do prazo e esta é a única solu...

William: - Sem mais o projeto está interditado, e será usado apenas como um último recurso esta fechada a audiência.

Ryan e Abganel saem inconformados apesar de saberem que havia mesmo os riscos. Ambos se retiram para descansar já que estavam exaustos devido ao tempo que se dedicaram ao engenho. No meio da noite escutam um estrondo enorme e todos da base acordam e vão verificar o que ocorreu.

Eles encontram Saduj que ligou o GBB, não agüentando ver Abganel desapontado.

Abganel: - O que você fez Saduj podemos estar condenados!

Saduj: - Ou salvos. Eu fiz a sua vontade, no fundo o senhor sabe que é sua vontade.

Ryan: - O GBB não estava programado...

Saduj: - Eu mesmo o programei, está começando está funcionando! meu caro?!

Abganel olha para Ryan e nota que ele uma expressão aterrorizante e pergunta: - O que há

Ryan: - ...

Abganel: - O que está acontecendo!?

Ryan: - Super-nova. 
Mais uma vez o assunto foi relacionado aos buracos-negros. Sabemos que os dois alunos conversaram entre si. Com certa frequência, no mês destinado à elaboração do conto, eles vieram nos questionar sobre a relação entre a conservação da energia e os buracos-negros - e pareciam realmente entretidos com o problema. O processo de criação pareceu bastante conturbado, pelo menos para nossa percepção exterior. Vale salientar que nenhum deles criou uma Space-Opera, o que esperávamos que fosse acontecer devido ao que supomos ser um senso comum sobre o que é a ficção científica.

O resultado, a nosso ver, foi excelente. Podemos verificar que o uso do léxico científico revela um esforço para enquadrá-los aos jogos da linguagem científica. Os artifícios que eles empregaram para criar o "clima" de uma ficção científica são muito interessantes. No primeiro conto, além do conteúdo, o estilo - recheado de explicações lógicas didaticamente inseridas no meio da narrativa, usualmente na fala de um especialista no assunto - lembra os escritores da Ficção Científica Hard. No segundo conto, além disso, o aluno recheou o texto de siglas. Ademais, fica claro em ambas as histórias um temor em relação ao desconhecido, em relação aos frutos de uma pesquisa que envolve as fronteiras da ciência.

Os cuidados com o suspense e a estrutura narrativa também ficam evidentes. No segundo conto, existem alguns deslizes em relação à norma culta da língua portuguesa, o que talvez indique a falta de uma releitura antes de entregar o trabalho - ambos foram entregues no último dia do prazo (não estamos defendendo que a educação escolar se limite à norma culta, mas parece-nos que o estudante se propôs a segui-la e, por falta de uma revisão cuidadosa, entregou um texto incoerente).

Salvo a relativa curta extensão dos contos, ficamos muito satisfeitos com o resultado final. No fim das contas, o único porém é o mesmo que apontamos na outra atividade faltou-nos problematizar a ideologia que eles revelaram em suas produções. Aqui talvez tivesse sido interessante realizarmos entrevistas semi-estruturadas, como o fizeram os pesquisadores portugueses Pedro Reis e Cecília Galvão (2006).

Permitam-nos apresentar apenas mais um conto, fruto de outra atividade.

Impressionados com o resultado dos dois trabalhos acima, resolvemos elaborar estratégias que pudessem fomentar a criatividade de mais estudantes. Seis meses após a atividade anterior, estávamos preparando a época de física moderna para o último ano do ensino médio. Resolvemos ousar: em vez de algo tradicional, decidimos que trabalharíamos todos os conceitos por meio de narrativas. Assim, escolhemos o livro de George Gamow (1980) em que ele narra as peripécias do sr. Tompkins em sonhos que se passam em universos estruturados sobre constantes ligeiramente diferentes das de nosso universo - alterando a 
Constante de Planck, efeitos quânticos acontecem em nossa escala de tamanho; em um universo onde a velocidade da luz é muito mais baixa, os efeitos relativísticos acontecem no dia a dia; etc. Além disso, cada conto é seguido de um outro que, sob o pretexto de uma palestra de um professor, existe uma preleção sobre os conceitos científicos abordados no conto anterior.

Pois bem, de posse desse livro, líamos um conto em um dia e, no outro, o conto seguinte de caráter explicativo. Resolvemos que não iríamos avaliar os estudantes por meio de provas mecânicas ou tarefas fiscalizadoras, mas que, ao contrário, os alunos deveriam escrever para cada assunto abordado - ou seja, a cada dois contos lidos - uma narrativa de ficção científica, investigação policial, etc. Novamente, a única restrição: o assunto estudado por meio dos contos de Gamow deveria aparecer.

O conto que se segue foi elaborado por Rafael Coelho Martinez, e nos foi entregue em 10 de dezembro de 2009.

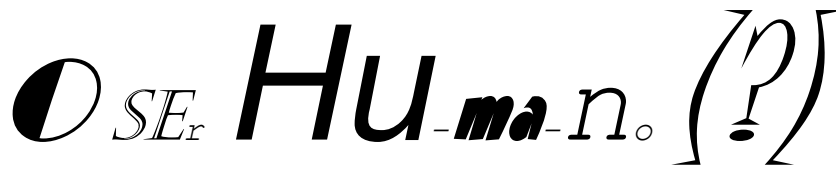

"A ciência tradicional conseguiu se espalhar por todos os ânimos. A única crença sobre a criação do mundo é, hoje em dia, a do Big Bang. Vivemos no século da racionalidade". As tecnologias dominaram o mundo, mas a ganância do homem conseguiu destruir quase tudo. Vivemos em um tempo onde não existe mais comunicação. Homens, mulheres, crianças, todos nós abolimos a fala. O único jeito de se comunicar com outro ser VIVO é por intermédio da luz. Toda essa informação, transformada em Fótons ${ }^{1}$, é enviada de um terminal localizado no pulso direito de cada indivíduo. Existe também um decodificador para transformar essas partículas em vibrações, para que a pessoa possa compreender o que foi dito.

Essa mudança dramática no modo de se comunicar foi um plano elaborado pelo Estado para obter um maior controle sob os indivíduos. Todos esses terminais estão conectados em uma rede, e assim, a comunicação pode ser filtrada.

Outro problema que aflige a nossa sociedade é a questão da alimentação. Desde 2145 que a transgenia tomou conta do mercado alimentício. Hoje, em 2190, não existem mais alimentos que remetam a natureza, todos são produzidos em laboratórios. Outra questão que nos preocupa é que desde o avanço da tecnologia, os nossos alimentos têm sido bombardeados por ondas eletromagnéticas ${ }^{2}$ provenientes de diversos aparelhos. Isto provoca uma mutação no seqüenciamento genético. A única forma de reverter este problema seria conseguir humanizar a consciência humana, mas isso já está perdido há muito tempo.

Outros problemas que perturbam a ordem pública são a escassez de água e obtenção de energia. Não podemos negar que o nosso $3^{\circ}$ Presidente após a era glacial não tentou combater essas questões. Todas as suas tentativas para obter uma energia limpa foram em vão. Não temos mais espaço para represar rios, ou mesmo para construir usinas de energia nuclear, pois o mar de prédios tomou conta do espaço físico. o que nos resta são os painéis de energia solar e essa nova tecnologia onde cada movimento do individuo 
está sendo transformado em energia para seu próprio consumo (em sua maioria para a bateria do terminal relacionado à fala).

Com relação a água, a nossa sociedade, graças ao mal uso, conseguiu gastar todas as nossas reservas para suprir suas atividades individualistas (lavagem dos carros voadores, limpeza em geral). Hoje, todas as casas têm um moderno sistema de captação de água, em caso de chuva. o que tem sido feito há alguns anos é provocar chuva de modo artificial. Partículas de vapor de água são enviadas para o céu (normalmente no meio de uma grande massa de nuvens) provocando a precipitação. Só que se imaginarmos isso para suprir necessidades de uma população mundial de 5.8 bi de habitantes, essa idéia começa a ser inútil.

Uma tecnologia que já está presente em nossa sociedade há muito tempo, mas tem se desenvolvido a passos largos é a simples questão da refração ${ }^{3}$. Coisas muito simples usam desta tecnologia, como o novo sistema coleta pessoal de água. O sistema está inativo e existe um feixe central de laser e depois receptores que recebem o sinal. Quando uma gotícula de água passa pelo laser (e pela refração desvia o curso do feixe, que não chega no segundo receptor) o sistema é acionado. Uma técnica muito simples, mas que tem modernizado nossas vidas.

Pretendo enviar esta carta para alguma parte remota do espaço. Espero que algum outro ser Hu ma no consiga, em tempos futuros, criar uma nova sociedade que não cometa os erros atuais. Espero que a paz transcenda todos os limites estabelecidos pela cultura hipócrita que estamos acostumados.

Rafael Coelho Martinez Escola Waldorf São Paulo

2190

Notas:

1. Foton é a partícula elementar mediadora da força eletromagnética. O fóton também é o quantum da radiação eletromagnética (incluindo a luz). Normalmente, a luz é formada por um grande número de fótons, tendo a sua intensidade ou brilho ligada ao número deles.

2. As ondas eletromagnéticas são ondas formadas pela combinação dos campos magnéticos e elétrico que se propagam no espaço perpendicularmente um em relação ao outro e na direção da propagação da energia.

3. Refração é a passagem da luz de um meio para outro. Chamamos índice de refração absoluto de um meio para determinada luz monocromática a razão entre a velocidade da luz no vácuo (c) e a velocidade da luz no meio considerado (v), representado pela fórmula $n=c / v$.

Uma curiosidade: o título do arquivo eletrônico que o aluno nos enviou com o conto chamava-se nova sociedade. Comparando com o título oficial acima, talvez seja correto afirmar que a preocupação do estudante era repensar a sociedade repensando o ser humano. Outra curiosidade: parece-nos evidente que a sloganização alienante e o assalto à palavra, presentes no livro 1984 de G. Orwell - que o aluno já havia lido - incomodaram-no o suficiente para que ele imaginasse um futuro distópico situado no ano 2190. Angustiado com a falta de comunicação verdadeira entre os humanos, ele filosofa sobre isso. Como dizia A. Camus, se você quiser filosofar, escreva romances.

Questões energéticas, água, alimentação... ele acertou em cheio alguns dos grandes problemas do mundo contemporâneo. Além da indignação com os rumos que a exploração da 
natureza tem tomado, verificamos que ele não desistiu da luta, pois - ainda que postergue a possibilidade de mudança para humanos futuros - encerra com uma mensagem de esperança.

No parágrafo em que ele fala da refração, vemos uma tentativa de esboçar um experimento de óptica que realizamos poucos dias antes. Mostramos um feixe LASER rebatendo em ziguezague nas paredes de um aquário, e comentamos que os limpadores de para-brisa automáticos funcionam quando uma gota de chuva com índice de refração semelhante ao do vidro do carro faz com que um feixe que caminhava em seu interior desvie seu caminho e pare de chegar a um sensor, o que aciona um motor.

Comparando com os contos anteriores, percebemos que este, escrito na forma de uma carta, possui alguns conceitos científicos inseridos no corpo do texto, e que os conceitos físicos que deveriam ser abordados foram explicados em notas de rodapé. Notas que, transcritas do site <http://pt.wikipedia.org>, evidenciam que o estudante teve de realizar uma pesquisa, ainda que tenha digerido pouco aquilo que leu. Mesmo assim, nos conceitos abordados no corpo da carta verificamos seu esforço para aplicar os jogos da linguagem científica, principalmente por conta de várias relações de causa e efeito que, imbuídas de tristeza, antecipam um desastre natural. Mas, lembremos, "a aplicação permanece um critério da compreensão" (WITTGENSTEIN, 1999, p. 74, grifo nosso). Para nós, tão importante quanto saber aplicar a retórica científica é conseguir reconhecer sua ideologia, algo que pecamos em não trabalhar naquela oportunidade.

O fato de o estudante ter aproveitado o ensejo do conto para inserir suas opiniões sobre questões científicas e tecnológicas não mencionadas em aula nos fez perceber que ensinar ciência não é disponibilizar um conhecimento externo, distante do aluno, mas justamente iniciar a partir da problematização daquilo que ele já conhece, pois é isso que lhe permitirá mudar de postura frente ao conhecimento e à vida.

Apesar de termos em mãos mais contos produzidos para essa atividade, pouparemos o leitor de outros exemplares. Mesmo porque, não estamos realizando análises profundas ou quantitativas (na época em que elaboramos as atividades acima, sequer passava pela nossa cabeça uma pretensão de acompanhar pari passu o desenvolvimento cognitivo dos alunos, e talvez o remendo saísse pior que a encomenda se tentássemos retificar essa pretensão agora, $a$ posteriori).

Vale destacar, por fim, que apesar de todos os alunos terem se empolgado com as histórias de Gamow e os contra-sensos da física moderna, nem todos realizaram seus próprios contos e outros, que criaram uma história, não a elaboraram com total afinco. 


\section{VIII.5 - 'AlÉm do Planeta SilenCioso’}

Pensando nos contos desses alunos-autores e relembrando as conversas que travamos durante os dias em que eles pensaram e repensaram para criá-los, parece-nos que eles se sentiram suficientemente instigados como sujeitos cognoscentes, tornando-se capazes "de inteligir e comunicar o inteligido" (FREIRE, 1996, p. 119).

O que esses contos sugerem é que a criação de narrativas pelos próprios alunos é uma possibilidade ímpar, talvez deixada de lado no ensino de ciências por conta de uma ilusória distância entre o conhecimento objetivo que os alunos devem aprender e suas opiniões sobre os assuntos científicos. No final das contas, se eles forem requisitados apenas a imitar e repetir mecanicamente a voz dos cientistas, se o único produto que eles puderem produzir for desprovido de genuína inquietação, a ciência terminará como instrumento de coerção. A aprendizagem do educando tem muito a crescer se aquilo que ele produzir for mais do que o eco matemático de uma linguagem distante, de um conteúdo alienígena, se ele tiver o que dizer e um motivo para isso. Se ele for sujeito do que diz. Se ele for ouvido.

Parece-nos que, ao escrever o próprio conto, cada aluno não se limitou aos conceitos que nós pesquisamos quando preparamos as aulas. Cada um realizou seu próprio tour de force pelo conhecimento, elaborando um elemento de cultura para expressar sua compreensão do mundo. A esse convite ao diálogo alguns aceitaram de bom grado, demonstrando prazer ao criar. Outros, contudo, realizaram tal atividade a contragosto, por razões burocráticas. Restanos, portanto, o desafio pedagógico de tentar revelar a acomodação a que nos submete nossa realidade opressora para que, reconhecendo-a, cada um se questione se há uma diferença entre consumir ideias e criticar/produzir ideias. De acordo com nossas experiências, as atividades envolvendo a ficção científica parecem possuir um potencial muito pouco utilizado nas escolas, pois, por meio dela, os jovens podem desenvolver suas práxis criadoras do futuro.

Em considerações como aquela da aluna que se incomodou com o sono-ensino, fica claro que as situações imaginadas pelos escritores, ainda que fictícias, possuem muito potencial pedagógico. Afinal, o estudante, como leitor real, é um interlocutor real. E seus valores, em conflito ou ressonância com o texto, abrem as portas para o processo de aprendizagem. A estética da produção do autor encontra-se com a estética da recepção do leitor, reverberando ou demolindo, em sua força catártica, a visão de mundo anterior deste. Portanto, respeitar o educando enquanto interlocutor, enquanto ser pensante e desejoso de atuar no/com o mundo é fundamental. Mais fundamental ainda é adotar uma prática pedagógica que não estacione na mera motivação inicial. 
Nossa maior falha, nesse sentido, foi fomentar apenas a aprendizagem da retórica científica sem aproveitar para sopesar a ideologia que lhe vem a tiracolo. Sem ponderar sobre as ideologias, não podemos nos reconhecer opressores-oprimidos. Esse reconhecimento é essencial para assumirmos nossas vidas, para inconformarmo-nos com a ordem social alienante que se alastra na quase totalidade do mundo e do nosso país. Essa indignação é necessária para mudarmos de postura, para construirmos 'Outros Brasis', para nos orgulharmos do lema de nossa bandeira, quem sabe na forma "nova ordem e progresso". 


\section{(IN)CONCLUSÃO}

$\boldsymbol{O U}$

\section{'MATRIX REVOLUTIONS'}

Oráculo: Tudo que tem um começo tem um fim.

Matrix Revolutions, 2003, 00h29m07s.

Arquiteto: Você arriscou um jogo muito perigoso.

Oráculo: Mudanças sempre o são.

$\ldots$

Sati: Nós veremos o Novo novamente?

Oráculo: Eu suspeito que sim. Algum dia.

Serafim: Você sempre soube?

Oráculo: Oh, não. Não sabia. Mas eu acreditei... Eu acreditei...

Idem, cena final. 
Sabendo que toda conclusão é sócio-historicamente restrita, e que tudo que começa acaba, finalizemos essa nossa crença na necessidade de mudanças estruturais escolares e sociais - de uma revolução na matriz - com a declaração de que estamos ansiosos por novas propostas que venham a enriquecer a discussão e, eventualmente, a prática da inserção da ficção científica na escola. Como dissemos no início do trabalho, infelizmente ainda há pouca produção sistemática sobre esse assunto no Brasil.

Antes de enveredarmos para o último ponto, desferirmos o último nó, recapitulemos nossa viagem ${ }^{78}$. Permitam-nos um anacronismo saudosista:

\section{REBOBINANDO O FILME}

Iniciamos nossa jornada nas estrelas, escolhendo alguns referenciais dentre inúmeras possíveis constelações. No processo, eles nos auxiliaram a enfrentar diversos mitos que nublavam nossa tentativa de vislumbrar o funcionamento escolar, e que tivemos de deitar ao solo antes de chegar a esta conclusão.

O primeiro foi uma tremenda revolução para nós mesmos - Paulo Freire e sua denúncia da estrutura massificante da sociedade, massacre refletido nos conhecimentos estáticos, especializações cada vez mais dispersivas e irreconciliáveis supostamente transferidas por nossas escolas. Comparada à educação bancária, que modela a escola, o conhecimento e o ser humano com virulenta rigidez hermética, como objetos quase mortos, estatelados, produtos de uma autoridade que nega a alteridade, nossa proposta baseou-se em outras concepções. A saber:

- O ser humano é sujeito ontologicamente inconcluso e curioso;

- Mas sua curiosidade pode ser sabotada em contextos sociais opressores.

- O saber genuíno, mesmo limitado historicamente, fornece elementos para mudar nossa visão e nossa postura frente ao mundo;

- Mas pode ser instrumento de opressão se for desumanizado.

- A escola é palco de diálogos e de desafios individuais e coletivos.

- Mas, se se resumir a conhecimentos inoperantes e fragmentados, fragmenta o homem.

\footnotetext{
${ }^{78}$ Não podemos encerrar o trabalho sem realizar uma última confissão. Após as excelentes sugestões recebidas no exame de qualificação, reformulamos quase que completamente esta dissertação (supomos que apenas cerca de 5\% do texto original tenha permanecido). Aprendemos muito nesse período, vide a trajetória que recapitularemos neste momento. Com isso, aproveitamos para agradecer novamente aos membros da banca daquele exame e ao nosso orientador que nos guiaram por novos, estimulantes, transformadores e gratificantes caminhos.
} 
Como educar não é treinar, essas concepções, na verdade, são frutos de um cuidado: queremos uma sociedade construída por seres autônomos ou autômatos?

Nessa investigação, concluímos ser premente conceber o homem como indissociável da sociedade, pois o caminho que leva à autonomia inicia-se no reconhecimento do conformismo incutido em nossas mentes pela "ordem" social que aí está. Começa na percepção de que, ignorando os modos de funcionamento da estrutura alienante, tornamo-nos oprimidos-opressores, espoliando-nos de nossa própria humanidade. Possibilitado tal reconhecimento, a boa angústia socrática que impulsiona a aprendizagem dependerá de uma postura esperançosa e perseverante, respaldada na confiança nos outros e em nós mesmos. Construída sobre todos esses cuidados, a metodologia freiriana foi a 'fundação' de nossas reflexões, e foi por meio dela que buscamos nos contrapor à violência escolar - último refúgio da incompetência social.

Mas essas conclusões só foram possíveis após reconhecermos o diálogo humilde como a essência e o motor da aprendizagem. Para tanto, tivemos de descer do palanque em que pregávamos a ciência como o único caminho para a liberdade, como a única fonte da verdade. E tal percepção de 'admiráveis mundos novos' só se tornou viável graças aos diálogos que travamos com filósofos, historiadores e sociólogos da ciência por meio dos trabalhos de Zanetic. Sem isso, continuaríamos acreditando que, pela ciência, detínhamos as chaves para a libertação dos ingênuos e ignorantes. Mas ninguém é sujeito da liberdade nem da autonomia de ninguém. Pior do que isso, naquela presunção messiânica, mal percebíamos que, supondo-nos detentores de uma verdade desconhecida de outros, tornávamos veículo da opressão, sustentávamos a verticalização. Despir-nos dessas atitudes, reconhecermo-nos oprimidos-opressores, é um processo doloroso, e que não teria se iniciado sem algumas meditações a respeito da linguagem.

Primeiro nos afastamos de uma concepção limitante que concebia a linguagem como mera etiqueta de objetos e conceitos ao contrapô-la ao pensamento do primeiro Wittgenstein. Ao passarmos a conceber a estrutura das proposições (e não as palavras isoladas) como um reflexo da estrutura da realidade, acudiu-nos o segundo Wittgenstein - com a visão de que não há uma correspondência unívoca, com a realidade sendo espelhada pela linguagem, mas de que esta adquire sua validade no contexto em que é empregada. Nesse sentido, filosofar é libertar o pensamento dos jogos da linguagem legitimados pelos paradigmas sociais. Após nos debatermos por um tempo, tentando nos libertar $d a$ linguagem, aprendemos com Bakhtin a nos libertar pela linguagem. Isto é, os enunciados estão repletos de ideologias. Algumas nós percebemos, outras sequer imaginamos que possam existir. Porém, o contexto histórico não é 
imutável; pela práxis, suas ideologias podem ser compreendidas e transformadas. Ideologias estas que se infiltram em nossas mentes desde a mais tenra infância, quando começamos a aprender a falar. Para nos convencermos disso, tivemos de adentrar brevemente nos bosques da psicologia, ainda em nossa 'viagem fantástica rumo ao cérebro'.

Nela aprendemos as críticas de Lev Vygotsky a uma psicologia que está mais preocupada em rotular do que fornecer meios de estimular o desenvolvimento; e, sua observação de que o conhecimento científico não substitui o conhecimento prévio dos aprendizes. Isso nos auxiliou profundamente a repensar nossa concepção de escola. E, com os relatos de seus experimentos, aprofundamos aquela perspectiva de Bakhtin: a intersubjetividade precede a subjetividade; a linguagem - e consequentemente o pensamento - é uma interiorização da linguagem social. Desta feita, todas as ideologias que a linguagem carrega ("Pedro é pobre, mas é esforçado") são "DNAlizadas" gradativamente a partir da infância, conforme vamos aprendendo a nos expressar. Quando falamos, vozes de outros falam pela gente. Quando raciocinamos, nossa lógica é um reflexo da lógica das instituições sociais que nos modelaram desde pequenos. O que nos remete novamente à ciência, visto que afirmar no meio de uma conversa "isso já foi provado pelos cientistas", ao invés de supostamente enriquecer o raciocínio crítico frente a algum assunto, muitas vezes serve mesmo é para dar cabo do diálogo sem que a outra pessoa tenha chance de resposta.

Com essa visão de mundo assentada em um 'nós' consciente de que o futuro é um livro ainda por escrever (visto que ser condicionado não significa ser terminantemente determinado) finalmente fomos encarar a ficção científica. Mesmo porque seus escritores também utilizam o artifício de empregar o léxico e os jogos da linguagem científica para convencernos a suspender a incredulidade, a aceitar a verossimilhança do universo que nos apresentam. Portanto, mais do que nos deliciarmos com a imaginação divertidíssima desses autores que entretecem 'as cidades e as estrelas', convém, na prática pedagógica, problematizar a ideologia que eles propagam. Assim, propusemos a ficção científica como barômetro cultural, indicador de pressões e opressões sociais, de tensões existenciais na atmosfera de uma unidade epocal.

Aprendemos com M. Elizabeth Ginway que as alegorias da ficção científica, quando interpretadas com atenção, revelam muito sobre o contexto social de seus escritores e escritoras: na relação mestre-servo entre homens e máquinas, subjazem tensões raciais; na relação eu-outro entre homens e alienígenas, camuflam-se xenofobias e questões coloniais; na relação homem-natureza, oculta-se a sujeição feminina a uma sociedade falocrática. E, pensando na educação científica, mais importante do que problematizar as alegorias e o que 
elas representam em nossas relações com os outros e com o mundo, é perceber como a dinâmica dessas relações foram e são influenciadas pela industrialização acelerada e pela urbanização desregulada. Nesse ínterim, vimos que, como símbolos da resistência às mudanças trazidas pelo "desenvolvimento", os mitos utilizados pelos escritores trazem um senso de continuidade à comunidade imaginada de nosso país. Porém, muitos mitos de identidade nacional são fictícios e podem dificultar a busca de soluções para os problemas advindos com a "modernização".

Não podemos nos apegar apenas às interpretações alegóricas, é bom frisar. Piassi, utilizando seus pólos temáticos para analisar um conto de Asimov em que um robô sonhador é assassinado aponta:

O que ocorre no final de uma história dessas é que alguns alunos acham que a destruição de uma máquina consciente é uma atitude eticamente deplorável, enquanto outros tendem a considerar o robô como uma mera máquina. Trata-se, portanto, de uma questão ética, que está, de alguma forma, presente em todas essas histórias. É interessante, nesse tipo de conto, o equilíbrio existente entre uma dimensão de alegoria (robôs e personagens como representação) e conjectura (as possibilidades imaginadas em um futuro com robôs). Do ponto de vista alegórico, é praticamente evidente a associação com a relação senhor-escravo, na qual este é considerado um objeto, uma propriedade e na qual o medo da revolta é uma constante. Mas essa interpretação não nega a possibilidade que está no plano literal - a de produzir máquinas que possuam um nível de consciência. O que fazer então? O significado alegórico nos lembra do que, na história da humanidade, foi feito. Há fases de exploração brutal, mas há lutas e conquista de reconhecimento de direitos também. Isso tudo, por outro lado, leva a uma outra questão - devemos criar máquinas conscientes? (PIASSI, 2007a, p. 8).

Ou seja, as alegorias nos auxiliam a nos conscientizarmos da dinâmica dos mitos culturais. Com isso podemos nos conscientizar de nossos próprios atos que, muitas vezes, se tornam desumanos por conta de um condicionamento cultural a que estamos submetidos em uma sociedade que, muitas vezes deprimente, nos induz a apegarmo-nos a tais mitos. Problematizá-los é uma forma de repensarmos nossas escolhas, é uma forma de reconstruirmos nossas vidas. O mundo é caótico, dinâmico, modelado pela velocidade; os produtos da ciência e da arte são ordenados. Aprendemos, com elas, leis naturais e morais - sóciohistoricamente delimitadas - e não podemos supor que elas são eternas, únicas e últimas. Reconhecemos suas limitações, ponderamos sobre suas validades, guiamos nossas atitudes e assumimos a responsabilidade por nossas escolhas.

Por isso, seguindo a metodologia freiriana, a esperança reside no 'diálogo dos mundos' e não na cacofonia de uma torre de Babel. Em uma educação não verbosa, onde tornamo-nos mais e mais desejosos de compreender-atuar no/com o mundo, aprenderemos 
muito da linguagem científica ao mobilizar-nos na postura cripto-crítica, ao engendrarmos uma voluntária odisseia hermenêutica, verdadeira navegação pelos mitos culturais presentes na ficção científica, decriptando e criando seus códigos-narrativos.

Navegadores antigos tinham uma frase gloriosa: "Navegar é preciso; viver não é preciso".

Quero para mim o espírito [d]esta frase, transformada a forma para a casar com o que eu sou: Viver não é necessário; o que é necessário é criar (PESSOA, 1999, p. 15).

Em meio a essas peregrinações e cocriações, retornamos às questões dos jogos da linguagem científica compartilhados pela ciência e pela ficção científica. Jogos que, modeladores de uma forma de pensar e, portanto, guias de uma atuação no mundo, não se apresentam como meras fantasias, mas como verdadeiras 'tangentes da realidade'. Jogos que, também repletos de mitos e ideologias, tornam-se outra fonte de atividades pedagógicas de caráter emancipador.

Resumindo. A sociedade atual é amplamente mítica. Mitos políticos, científicos, econômicos..., abstrações culturais incutidas em cantos ocultos de nossa cultura interior, escravizando nossas formas de pensar e de conceber o mundo. Nesse sentido, uma educação genuína inicia-se quando confrontamos esses simulacros a ponto de nos questionarmos: "o que estamos fazendo de nossas vidas?”. Desmitificar é aprender.

Para elucidar essa perspectiva, a analogia do educando com o detetive é muito reveladora. Não podemos, enquanto aprendizes, aprisionarmo-nos em nossas próprias mentes - precisamos dialogar inteligentemente com o mundo e as pessoas, no intuito de encontrar as respostas para nossas perguntas. De que adianta um detetive que não realiza investigações? Detetive acomodado não resolve mistérios, destarte, o que nos sustenta é o propósito, o desejo de investigar. E de que adianta investigar se não estivermos abertos a mudar nossa mente, se não buscamos desvendar os mitos que encobrem nossa visão de mundo? Um investigador continuamente vendado é um investigador que tateia no escuro.

E o que seria de Sherlock sem Watson? Se como educadores aceitarmos nossa humanidade, aprenderemos tanto com o educando quanto este conosco. Qual nossa função? Obviamente, somos os interlocutores do detetive, ajudando-o a organizar sua linha de raciocínio. Não podemos falar sem ouvir, muito menos falar continuamente sem permitir que o investigador medite sobre o problema. E mais, imaginemo-nos na cena do crime. Nossa função não é mostrar a estátua, no canto da sala, que resolve o enigma. O mundo é dinâmico, nós sequer conhecemos a solução! O que fazemos é apontar respeitosamente aquilo que 
supomos ser uma pista importante em uma negociação intersubjetiva de significados. Também não podemos supor que a simples indicação de uma ferramenta ou o uso mecânico de vários instrumentos resolverá o crime. Instrumentos não são nada sem o pensamento, sem a indagação cuidadosa e sistemática. Sem o desejo de utilizá-los.

E lembremos que há aqui uma simetria: o que dissemos sobre o detetive deve se estender para as atitudes e pensamentos de seu amigo-ajudante e o que dissemos sobre o amigo-ajudante serve para o detetive. Ninguém é inferior ou superior. A hierarquia totalitária é um assalto à responsabilidade dos submissos. Só assim detetive-ajudante e ajudante-detetive trabalharão em verdadeira união, buscando o mesmo objetivo: aprender.

Para os fãs de ficção científica, talvez fosse mais interessante outra analogia: jedispadawans e padawans-jedis lutando pela liberdade na galáxia! Mas o que importa é um ponto crucial que não pode ser ignorado: a escolha do caso a ser investigado. O mundo é repleto de problemas. Ele nos incita a tomar parte a cada instante. Logo, em primeiro lugar, não podemos massacrar a curiosidade do detetive. Não podemos mascarar ou esconder-lhe os problemas do mundo - podemos errar, mas mentir jamais. Tampouco podemos indicar o problema e a resposta ao mesmo tempo (reforçando: nós também não sabemos a resposta, e temos de cuidar para não nos colocarmos no papel do "expert" ideológico). O caso deve instigar a nós e ao detetive, deve afligir a ambos. Investigação não é invasão, mas convivência, ação no mundo e aprendizagem mútua.

Isso quer dizer que o detetive nunca irá aprender como funciona um micro-ondas? Muito pelo contrário. Ele irá aprender quando esta aprendizagem fizer sentido, portanto, quando for uma necessidade visceral aprender. O cuidado inicial, contudo, é verificar se nós, ajudantes e detetives, não estamos acorrentados aos nossos próprios pensamentos, se não estamos acomodados, se não nos dobramos sob o peso de nosso próprio conformismo, se não nos tornamos alienados-alienantes. Como vemos, existe uma sequência de crimes a serem investigados. Lembremos, esta é uma pedagogia que começa na indignação, no desassossego com os problemas do mundo e com nossa própria ignorância. Nesta dissertação, restringimonos a questões relativas a essa inquietação que retira do alheamento. Despertos os detetives adormecidos, resta-nos futuramente pensar nos crimes mais específicos.

\section{FECHANDO O CiClo}

Como antecipamos na introdução, perdoem-nos pela extensão desta dissertação, mas escrevêmo-la para nosso eu de anteontem - desnorteado em meio à neblina de muitos mitos 
ignorados. Certamente, carregamos ainda vários outros mitos inconscientes e confessamos que foi somente com o passar dos meses, conforme escrevíamos e reescrevíamos os capítulos, que muitas fichas - permitam-nos outro saudosismo - começaram a cair. Olhando para o passado, sequer conseguimos contabilizar quanta gente possivelmente maltratamos ou magoamos por conta dos construtos que assumíamos como forma inequívoca de pensar o mundo e a relação entre as pessoas.

Inicialmente, pretendíamos apresentar a ficção científica como uma forma de cativar pela ciência. Demoramos a perceber que esse cativar significava, na verdade, convencer, capturar. Seduzidos em meio a uma sociedade cada vez mais tecnológica, tornamo-nos "tecnófilos" afobados e pretendíamos apresentar o futurismo da ficção científica para propagar essa devoção. Lamentamos nossa lentidão para perceber que, assim, mais aprisionaríamos que libertaríamos. Que o papel do estudante, em tal concepção, seria mais repetir a música urbana do que reformular sua sinfonia.

Infelizmente, devido a essa compreensão tardia, as atividades que aplicamos na escola em que lecionamos não foram embasadas nas reflexões anteriores, pois foram realizadas muito antes de erigirmos tal visão de mundo. Ainda assim, elas parecem indicar que incitar a criatividade e não a mera repetição mecanizada de algoritmos é uma postura muito frutífera. Mas se tem algo que aprendemos com tais atividades é que nem todos os alunos davam asas à criatividade e assumiam a responsabilidade pela própria aprendizagem quando possibilitávamos essa postura. Isso nos fez indagar: por quê? Atualmente, desconfiamos que é porque uma atividade dialógica isolada não opera milagres em meio a uma sociedade marcadamente cruel. Não podemos nos abster de discutir frequentemente na escola as questões que nos alienam, que confinam nossa cultura, as situações-limite que governam nossas mentes. O diálogo começa na escolha dos conteúdos. Não faz sentido usar a metodologia freiriana pela metade e depois desvalidá-la por ela não funcionar.

No geral, nossa esperança reside em uma percepção:

Culturas possuem vida própria: são antes organismos que organizações (OTERO, 1987, p. 9).

$\mathrm{O}$ que nos remete aos pesquisadores com quem estabelecemos um 'contato imediato' no início deste trabalho. Alguns deles propõem a ficção científica como uma forma cultural de estimular a paixão pelo conhecimento, de cativar pela racionalidade científica, de garantir a afeição pela imaginação e pela criatividade. Concordamos com tudo isso, porém, como apontamos acima, devemos ter cuidado com o propósito dessa afeição. Alguns deles pareciam partir do pressuposto de que a ciência deve ser aprendida sem que o motivo dessa 
necessidade fosse discutido com o educando. Neste nível, aquilo que propõem parece ser mais invasão do que emancipação. A ficção científica, desse ponto de vista, seria instrumento de opressão, mero "manual de devoção da sociedade industrializada" - para utilizar as já citadas palavras de Cuartas. Mas, se considerarmos que a liberdade depende do entendimento dos mecanismos de funcionamento daquilo que nos aprisiona, talvez possamos afirmar que muitas daquelas pesquisas, ao discutirem o fazer e o quefazer científico, apontam sim no sentido de restituir a liberdade aos aprendizes. Acreditamos somente que isso poderia ser feito de forma menos velada. A nosso ver, as escolhas, as cartas devem ser postas todas na mesa, pois são as reflexões genuínas, incômodas, que levam à ação voluntária verdadeiramente educativa.

A alegria pode prescindir da razão, mas reflexão sem compreensão é vazia. Existe satisfação em meramente observar o mundo, mas essa satisfação pode ser aprofundada quando a visão da mente consegue penetrar na superfície das coisas para enxergar as conexões existentes (P. W. Atkins apud ROCCA; CURI, s/d, p. 7).

Para nós, o prazer, a afeição, a imaginação, tudo isso se mostra genuíno no fazer humanizador - aquele que busca compreender os mecanismos do mundo e atua em prol da bondade. "A filosofia não está no saber, e sim no fazer" (ROWLANDS, 2005, p. 14). Por isso a educação não pode se limitar a conceitos inoperantes, por meio dos quais agir é apenas obedecer. Mais uma vez relembrando a frase de Camus: aprender que o mundo tem três dimensões ou que o espírito tem doze categorias é desnecessário se isso não for fruto de um desejo de compreender-atuar verdadeiramente no mundo. Reflexão e ação são como os pedais de uma bicicleta em movimento, um impulsiona o outro para frente.

Isso significa que somos partidários do utilitarismo? Não. O conhecimento pelo conhecimento, por assim dizer, é uma postura válida - ruim é acomodar-se. Nós podemos e devemos sentir prazer em buscar saber cada vez mais - desde que essa postura não seja guiada por um revanchismo míope, por uma vontade de saber mais do que os outros para, de alguma forma, oprimi-los. Lembremos: libertar-se não é libertar-se $d a$ ciência, $d a$ religião, $d a$ política; mas, em conjunto, libertarmo-nos pela ciência, pela religião, pela política... Ademais, a vingança não é uma postura que deva ser incentivada pedagogicamente. Nossa luta é contra instituições, não indivíduos (Rosa Luxemburgo apud SCHWARTZ, 1992, p. 141). Nosso ponto de referência há de ser sempre o prazer de nos libertarmos dos grilhões de nossa própria ignorância, e os outros e a natureza não devem ser subjugados, pois que não há critério que prove que um indivíduo é absolutamente melhor que os demais - principalmente em uma sociedade que nos induz a agir de forma desumana constantemente (não podemos ignorar que somos seres altamente sugestionáveis). Isso não quer dizer que não há 
escapatória, pois podemos mudar. É justamente pela práxis, pelo diálogo inteligente com os outros e com o mundo que entendemos e atuamos no drama cósmico; que libertamo-nos dos pensamentos furtivos que carregamos apenas por estarmos vivos, que incorporamos por vivermos em determinado contexto histórico. Dialogar-refletir-agir-dialogar-refletir... Afinal, ações são inevitáveis. Suas consequências também.

Nesse sentido, educar não é instrumentalizar para que o aluno possa, futuramente, ter acesso a uma cultura que ele eventualmente desconheça. Dia após dia somos massacrados por nossa cultura carregada de mitos que controlam nosso raciocínio e ditam nossas atitudes, inclusive em questões científicas. Educar é elucidar essa cultura presente, revelar-lhe as nuances, desvelar-lhe as perversidades e as possibilidades. Educar é libertar do presente e não treinar para o futuro. É buscarmos, em comunhão, evidenciar as intenções por trás do que está aí, a nossa volta, e que, vez ou outra, no turbilhão acelerado da rotina moderna, deixa-nos incomodados, com um espeto na mente.

Onde entram o ensino de física e a ficção científica nesse processo? Atualmente, ciência e tecnologia são causas de muitas angústias e maravilhamentos, sentimentos muito bem traduzidos pela ficção científica. Todavia, esses sentimentos, mais que puro reflexo de questões biológicas, são condicionados por mitos culturais - mitos que podem ser desvelados de forma que se humanizem os humanos e historicize-se a história. Em outras palavras, para o aluno reconhecer as questões científicas como sendo de seu interesse, não podemos reduzi-las àquilo que ele eventualmente aprecie ou abomine, esperando que, por um efeito cascata, ele saiba cada vez mais e algum dia torne-se crítico. Devemos abordar na escola justamente aquelas questões que limitam sua (nossa) forma de pensar, para que ele, reconhecendo-as como tal, atue conscientemente: busque compreendê-las para delas libertar-se.

Pelas nossas atuações em sala de aula, acreditamos que medidas paliativas não acertam o cerne da questão: no ensino tradicional, o indivíduo, constantemente retalhado, é exilado de seu próprio querer. As medidas atenuantes, que buscam motivar este querer desiludido pelo entretenimento e o lúdico, podem colocar em movimento, mas sozinhas muito provavelmente não realizarão milagres. É preciso mais do que o prazer para reavivar o desamparado, é preciso um propósito: o de libertar-se. Afinal, o prazer não é a única coisa que faz a vida valer a pena (ERION; SMITH, 2003, p. 59). Ainda que ele seja essencial e necessário à vida, sem reconhecer a seriedade das prisões que perpetuamente nos limitam, dificilmente nossos atos serão genuínos e significativos, raramente nossas aprendizagens nortearão nossas escolhas, e provavelmente continuaremos propagando visões de hierarquias desumanizantes. 
A vida não examinada não vale a pena ser vivida (IRWIN, 2003, p. 46).

E, pior, na ilusão da liberdade reside a conivência com a maldade. Portanto, não podemos subestimar a força demolidora que nossa sociedade exerce sobre o indivíduo em formação levando-o a desistir da própria existência, a ignorar as próprias escolhas ao repetir pensamentos limitantes, mortificantes. Esse foi o cerne de nossa dissertação: muitas vezes, quando a cultura incute valores, a sociedade desabilita a vontade, a humanidade de cada indivíduo oblitera-se. Porém, pelo exercício intelectual e espiritual que foi nosso percurso nesses últimos anos, não mais agarramo-nos a certezas com tanta presunção. Se nem as perguntas são eternas, as respostas devem ser efêmeras. Isto é, nossa linha de raciocínio pode estar equivocada. Ainda assim, uma mensagem intensa reverbera diariamente em nossa mente, e é, hoje em dia, nossa crença mais forte: é possível educar sem oprimir!

Daí termos encarado com certo cuidado os trabalhos daqueles autores que defendem a ficção científica para trabalhar o lúdico, a afeição, a imaginação, etc. Mas talvez toda essa digressão seja apenas fruto do encontro de jogos de linguagem com origens em filosofias diferentes, mas que, por fim, apontem na mesma direção. Darko Suvin (1984, p. 97) diz não acreditar na originalidade individual. O prazer e a criatividade estão limitados pelos condicionamentos sociais, conforme os indivíduos aclimatam-se ao espírito, ao "clima da época". Nesse sentido, tanto as pesquisas que pretendem motivar pelo prazer quanto nossa preocupação emancipadora apontam as mesmas conclusões. O que estamos fazendo é tentar encaixar essa outra visão em nossa perspectiva, acarretando que esse prazer pelo conhecimento é um segundo passo, subordinado à necessária emancipação das anestesias culturais. Mas não descartamos a hipótese de que essas visões sejam concomitantes, e talvez estejamos apenas nos perdendo em pretextos similares ao tentar descobrir o que vem primeiro, ao conjeturar o que é o ovo e o que é a galinha.

No fim, nossa posição é simples: somos 'filhos da esperança,79, desejamos o nascimento do novo em meio à opressão. Uma supernova que não apenas inverta as dicotomias, mas subverta-as. E, como sonhar nunca é demais, gostaríamos de estar vivos para acompanhar o deletar do que Freire delatou, permitindo às mulheres, aos homens e ao mundo uma...

'Vida longa e próspera!'

\footnotetext{
${ }^{79}$ Esse filme, do diretor Alfonso Cuarón, é bastante simbólico. Mais uma ficção distópica que, ao assustar, educa. Em um mundo envelhecido onde, por conta de problemas de fertilidade, não nasce uma criança há 18 anos, uma grávida inesperada se vê em perigo em meio a uma guerra.
} 


\section{BIBLIOGRAFIA}

ABRAMCZUK, André Ambrósio. O mito da ciência moderna. Proposta da análise da física como base de ideologia totalitária. São Paulo: Cortez Editora/Autores Associados, 1981.

ADAMS, Douglas. O guia do mochileiro das galáxias. Rio de Janeiro: Sextante, 2004. O restaurante no fim do universo. Rio de Janeiro: Sextante, 2004b.

ALLEN, L. David. No mundo da Ficção Científica. São Paulo: Summus Editorial, Original em língua inglesa de 1974. Edição em língua portuguesa sem data.

ALTHUSSER, Louis. Aparelhos ideológicos de estado. 10ª ed. Rio de Janeiro: Edições Graal, 1985.

ALVES, Rubem A. Filosofia da Ciência - introdução ao jogo e suas regras. ( $1^{\mathrm{a}}$ ed.: 1981). $21^{a}$ ed. São Paulo: Brasiliense S. A., 1995.

ANDRADE, Carlos Drummond de. Antologia Poética. Rio de Janeiro: J. Olympio, 1983.

ANDRADE, Mário. Macunaíma. 30ª ed. Belo Horizonte-Rio de Janeiro: Vila Rica, 1997.

ANJOS, Augusto dos. Eu e outras poesias. São Paulo: Martins Fontes, 1994.

ASIMOV, Isaac. A Fundação e a Terra. Rio de Janeiro: Record, 1986. Eu, robô. Ediouro, s/d.

FUNDAÇÃO - Trilogia: Fundação; Fundação e Império; Segunda Fundação. São Paulo: Hemus editora, 1982.

. No mundo da Ficção Científica. Rio de Janeiro: Francisco Alves, 1984.

. O cair da noite. In: ASIMOV, I. O cair da noite. São Paulo: Hemus, 1981.

. Os ventos da mudança. São Paulo: Hemus, s/d.

- Viagem Fantástica II: Rumo ao Cérebro. São Paulo: Best Seller, s/d. Edição original em inglês de 1987.

BACH Jr., Jonas. Educação Ecológica por Meio da Estética na Pedagogia Waldorf. 2007. 241p. Dissertação (Mestrado) - Setor de Educação, Universidade Federal do Paraná, Curitiba, 2007.

BACON, Francis. Novum Organum. São Paulo: Nova Cultural, 1999.

BAKHTIN, Mikhail M. (V. N. Volochínov). Marxismo e filosofia da linguagem: problemas fundamentais do método sociológico da linguagem. $12^{\mathrm{a}}$ ed. São Paulo: Hucitec, 2006.

BALLARD, J. G. Crash! São Paulo: Marco Zero, 1988.

BARRELO Jr, Nelson. Argumentação no discurso oral e escrito dos alunos de ensino médio em uma sequência didática de física moderna. Dissertação (Mestrado - PósGraduação em Educação. Área de Concentração: ensino de Ciências e Matemática) Faculdade de Educação da Universidade de São Paulo. Orientação: Anna Maria Pessoa de Carvalho. São Paulo, 2010. 
BARROS, Diana L. P. Contribuições de Bakhtin às teorias do texto e do discurso. In: FARACO, Carlos A.; TEZZA, Cristovão; CASTRO, Gilberto de (orgs.). Diálogos com Bakhtin. Paraná: Ed. da UFPR, 1996.

BORRÁS, Francisco José García. Bienvenido Mister Cine a la Enseñanza de las Ciencias. Revista Eureka sobre Enseñanza y Divulgación de las Ciencias (2008a), Vol. 6, No 1 , pp. 79-91.

. Cuando Los Mundos Chocan. Revista Eureka sobre Enseñanza y Divulgación de las Ciencias (2006), Vol. 3, $\mathrm{N}^{\circ}$ 2, pp. 268-286.

. House: otra forma de acercar el trabajo científico a nuestros alumnos. Revista Eureka sobre Enseñanza y Divulgación de las Ciencias (2008b), Vol. 5, № 2, pp. 212228.

. La serie C.S.I. como metáfora de algunas facetas del trabajo científico. Revista Eureka sobre Enseñanza y Divulgación de las Ciencias (2005a), Vol. 2, No 3, pp. 374387.

Star Trek: un viaje a las leyes de la dinámica. Revista Eureka sobre Enseñanza y Divulgación de las Ciencias (2005b), Vol. 2, No 1, pp. 79-90.

BRECHT, Bertolt. Poemas 1913-1956. São Paulo, Ed. 34, 2000.

. Teatro Completo Vol. 6 - Os fuzis da Senhora Carrar; Vida de Galileu; Mãe Coragem e seus filhos. Rio de Janeiro: Paz e Terra, 1991.

BRONOWSKI, Jacob. O senso comum da ciência. Belo Horizonte, Ed. Itatiaia; São Paulo, Ed. da Universidade de São Paulo, 1977.

BRUNER, Jerome S. Introdução. In: VYGOTSKY, Lev Semyonovich. Pensamento e linguagem. $2^{\mathrm{a}}$ ed. São Paulo: Martins Fontes, 1998.

BUNGE, Mário. Filosofia da Física. Lisboa: Edições 70, 1973.

Física e Filosofia. São Paulo: Perspectiva, 2000.

CANDOTTI, Ennio. Prefácio. In: MARTINS, André Ferrer P. (org.). Física ainda é cultura? São Paulo: Livraria da Física, 2009.

CAPECCHI, Maria Cândida Varoni de Morais; CARVALHO, Anna Maria Pessoa de. Argumentação em uma aula de conhecimento físico com crianças na faixa de oito a dez anos. Investigações em Ensino de Ciências, Porto Alegre, BR, v.5, n.3, 2000.

; SILVA, Dirceu da. Relação entre o discurso do professor e a argumentação dos alunos em uma aula de física. ENSAIO - Pesquisa em Educação em Ciências. Volume 02 / Número 2 - Dezembro 2002.

CARNEIRO, André. Introdução ao estudo da "science-fiction". São Paulo: Conselho Estadual de Cultura - Comissão de Literatura, 1967.

Pássaros florescem. São Paulo: Editora Scipione, 1988.

CARROL, Lewis. Alice no país das maravilhas. Porto Alegre: L\&PM, 1998.

CAUSO, Roberto S. Ficção científica, Fantasia e Horror no Brasil. 1875 a 1950. Belo Horizonte: Editora UFMG, 2003.

CAVELOS, Jeanne. A ciência de Star Wars (Guerra nas Estrelas). São Paulo: Market Books, 1999.

CHALMERS, Alan F. O que é ciência afinal? 1ª ed. São Paulo, Brasiliense, 1983. 
CID, Gabriel; COIMBRA, Carlos A. Q. (orgs.). Ciência em foco: o olhar pelo cinema. Rio de Janeiro: Garamond, 2008.

CIRNE, Moacy. Quadrinhos. Ficção Científica. Ideologia. In: Revista de Cultura Vozes. Ano 66, Vol. LXVI, jun./jul. 1972, n 5 - Ficção Científica: o discurso da era tecnológica.

CLARKE, Arthur C. A cidade e as estrelas. São Paulo: Abril Cultural, 1984.

COMTE, Auguste. Curso de filosofia positiva; Discurso preliminar sobre o conjunto do positivismo; Catecismo positivista. (Coleção Os pensadores). São Paulo: Nova Cultural, 1988.

COSTA, Jurandir Freire. Um sujeito sem qualidades. In: Jornal de Resenhas $\mathrm{N}^{\circ}$ 4. São Paulo: Discurso Editorial, agosto 2009. pp. 12-3.

CRICHTON, Michael. Estado de Medo. Rio de Janeiro: Rocco, 2005.

CUARTAS, Carlos Eduardo de Jesús Sierra. Fortalezas epistemológicas e axiológicas de la ciencia ficción: um potosí pedagógico mal aprovechado en la enseñanza y divulgación de las ciencias. Revista Eureka sobre Enseñanza y Divulgación de las Ciencias (2007), Vol. 4, No 1, pp. 87-105.

DELIZOICOV, Demétrio. Concepção Problematizadora do Ensino de Ciências na Educação Formal (Relato e análise de uma prática educacional na Guiné-Bissau). Dissertação de Mestrado em Ensino de Ciências - Instituto de Física e Faculdade de Educação, Universidade de São Paulo, São Paulo, 1982.

DELIZOICOV, Demétrio; ANGOTTI, José André; PERNAMBUCO, Marta Maria. Ensino de Ciências: fundamentos e métodos. $2^{\mathrm{a}}$ ed. São Paulo: Cortez, 2007.

D'OLIVEIRA, Armando Mora. Wittgenstein - Vida e Obra. In WITTGENSTEIN, Ludwig J. J. Wittgenstein. Investigações Filosóficas. Coleção Os Pensadores. São Paulo: Nova Cultural, 1999.

DÜRRENMATT, F. Os físicos. São Paulo: Brasiliense, 1966.

ECO, Umberto. Sobre os espelhos e outros ensaios. Rio de Janeiro: Nova Fronteira, 1989.

ERION, Gerald J.; SMITH, Barry. Ceticismo, Moralidade e Matrix. In: IRWIN, William. Matrix: Bem-vindo ao deserto do real. Coletânea de William Irwin. São Paulo: Madras, 2003.

FERREIRA, Ricardo Alves; ANDRADE, Thiago Santos de. Cinema e ensino de física. XVIII Simpósio Nacional de Ensino de Física. 26 a 30/jan/2009. Vitória, Espírito Santo.

FEYERABEND, Paul. Contra o Método. São Paulo: Fundação Editora da Unesp, 2007.

FIDELI, Finisia. A revolução feminista da FC. In: CULT - Revista Brasileira de Literatura. N. $6-\mathrm{jan} / 1998$.

FIKER, Raul. Ficção científica: ficção, ciência ou uma épica da época? Porto Alegre: L\&PM, 1985.

FREIRE, Paulo. Ação cultural para a liberdade e outros escritos. $5^{\text {a }}$ ed. Rio de Janeiro: Paz e Terra, 1981.

. A importância do ato de ler: em três artigos que se completam. $41^{\mathrm{a}}$ ed. São Paulo: Cortez, 2001. 
Extensão ou comunicação? 10ª ed. Rio de Janeiro: Paz e Terra, 1992.

Educação como prática da liberdade. $8^{a}$ ed. Rio de Janeiro: Paz e Terra, 1978.

Pedagogia da autonomia: saberes necessários à prática educativa. $41^{\text {a }}$ reimpressão. São Paulo: Paz e Terra, 1996.

Pedagogia do Oprimido. 46ª ed. Rio de Janeiro: Paz e Terra, 2005.

FREITAS, Maria Teresa de Assunção. Bakhtin e a psicologia. In: FARACO, Carlos A.; TEZZA, Cristovão; CASTRO, Gilberto de (orgs.). Diálogos com Bakhtin. Paraná: Ed. da UFPR, 1996.

. Vygotsky e Bakhtin - Psicologia e Educação: um intertexto. $4^{\text {a }}$ ed. São Paulo: Ática e EDUFJF, 2002.

GAMOW, George. O incrível mundo da Física Moderna. São Paulo: IBRASA, 1980.

GEHLEN, Simoni T.; AUTH, Milton A.; AULER, Décio; PANSERA-DE-ARAÚJO, Maria C.; MALDANER, Otavio A. Freire e Vigotski no contexto da Educação em Ciências: aproximações e distanciamentos. Revista Eletrônica Ensaio - Pesquisa em Educação em Ciências, Vol. 10, No 2 (2008). Disponível em: <http://www.portal.fae.ufmg.br/>. Acesso em 28 jan. 2010.

GINWAY, M. Elizabeth. Ficção científica brasileira: mitos culturais e nacionalidade no país do futuro. São Paulo: Devir, 2005.

GOMES-MALUF, Marcilene Cristina; SOUZA, Aguinaldo Robinson de. A ficção científica e o ensino de ciências: o imaginário como formador do real e do racional. Ciência \& Educação, v. 14, n. 2, p. 271-282, 2008.

GÓMEZ, M ${ }^{\mathrm{a}}$ Begoña Carretero. Un viaje al interior de la lectura com Julio Verne. Revista Eureka sobre Enseñanza y Divulgación de las Ciencias (2008), Vol. 5, No 3, pp. pp. 302-313.

GREF - Grupo de Reelaboração do Ensino de Física. Física 1: Mecânica. $7^{\mathrm{a}}$ ed. 1. reimp. São Paulo, Ed. da Universidade de São Paulo, 2002.

. Física 2: Física térmica/Óptica. $5^{\text {a }}$ ed. 2. reimpr. São Paulo, Ed. da Universidade de São Paulo, 2005.

. Física 3: Eletromagnetismo. $5^{\text {a }}$ ed. 4. reimpr. São Paulo, Ed. da Universidade de São Paulo, 2007.

GRESH, Lois H.; WEINBERG, Robert. A ciência dos super-heróis. Rio de Janeiro: Ediouro, 2005.

HUME, David. Investigação acerca do entendimento humano. São Paulo: Nova Cultural, 1999.

HUXLEY, Aldous Leonard. Admirável Mundo Novo. $7^{\text {a }}$ ed. Porto Alegre: Globo, 1980.

INFANTE, Ulisses. Curso de gramática aplicada aos textos. $4^{\mathrm{a}}$ ed. São Paulo: Scipione, 1996.

IRWIN, William (Coord.). Guerra nas estrelas e a filosofia: mais poderoso do que você imagina. Coletânea de Kevin S. Decker e Jason T. Eberl. São Paulo: Madras, 2005.

. Lost e filosofia: a ilha tem suas razões. Coletânea de Sharon M. Kaye. São Paulo: Madras, 2008. 
Matrix: Bem-vindo ao deserto do real. Coletânea de William Irwin. São Paulo: Madras, 2003.

Super-heróis e a filosofia: verdade, justiça e o caminho socrático. Coletânea de Tom Morris e Matt Morris. São Paulo: Madras, 2005b.

. Watchmen e a filosofia: um teste de Rorschach. Coletânea de Mark D. White. São Paulo: Madras, 2009.

. X-men e a filosofia: visão espantosa e argumento assombroso no $\mathrm{X}$-verso mutante. Coletânea de Rebecca Housel e J. Jeremy Wisnewski. São Paulo: Madras, 2009b.

JANIK, Allan; TOULMIN, Stephen. A Viena de Wittgenstein. Rio de Janeiro: Campus, 1991.

JOHNSON, Richard. Notes on the schooling of the English working class 1780-1850. In. Roger Dale et al (editors). Schooling and Capitalism. London: Routledge \& Kegan Paul, 1976.

JOHN-STEINER, Vera; SOUBERMAN, Ellen. Posfácio. In. VYGOTSKY, Lev Semyonovich. A formação social da mente: o desenvolvimento dos processos psicológicos superiores. 5a ed. São Paulo: Martins Fontes, 1994.

JONES, Jan-Erik. "Tamanho não importa": a Força como poder causal do Jedi. In.: IRWIN, William (Coord.). Guerra nas estrelas e a filosofia: mais poderoso do que você imagina. Coletânea de Kevin S. Decker e Jason T. Eberl. São Paulo: Madras, 2005.

KIPPHARDT, Heimar. O caso Oppenheimer. São Paulo: Brasiliente, 1966.

KRAUSS, Lawrence M. A física de Jornada nas Estrelas - Star Trek. São Paulo: MAKRON Books, 1996.

KUHN, Thomas S. A estrutura das revoluções científicas. São Paulo: Perspectiva, 1975.

LANZ, Rudolf. A Pedagogia Waldorf: caminho para um ensino mais humano. $5^{\text {a }}$ ed. São Paulo: Antroposófica, 1990.

LARANJEIRAS, Cássio Costa. Concepção de conhecimento e a dimensão cultural da ciência. In: MARTINS, André Ferrer P. (org.). Física ainda é cultura? São Paulo: Livraria da Física, 2009.

LE GUIN. Ursula. Os despossuídos: uma utopia ambígua. Rio de Janeiro: Nova Fronteira, 1978.

LEODORO, Marcos Pires. Ciência e cultura material: contribuições à educação científica. In: MARTINS, André Ferrer P. (org.). Física ainda é cultura? São Paulo: Livraria da Física, 2009.

LEWIS, C. S. Além do Planeta Silencioso. Rio de Janeiro: Edições GRD, 1958.

LODI-RIBEIRO, Gerson. Outros Brasis. São Paulo: Selo Unicórnio Azul, 2006.

LUCHETTI, Marco Aurélio. A Ficção Científica nos Quadrinhos. São Paulo: GRD, 1991.

MACHADO, Carlos Alberto. Filmes de ficção científica como mediadores de conceitos relativos ao meio ambiente. Ciência \& Educação, v. 14, n. 2, p. 283-294, 2008. 
MACHADO, Irene A. Os gêneros e a ciência dialógica do texto. In: FARACO, Carlos A.; TEZZA, Cristovão; CASTRO, Gilberto de (orgs.). Diálogos com Bakhtin. Paraná: Ed. da UFPR, 1996.

MAIAKÓVSKI, Vladímir. Vida e obra. $2^{\text {a }}$ ed. São Paulo: Martin Claret, 2008.

MARTINS, André Ferrer P. Sobre rupturas (e continuidades...). In: MARTINS, André Ferrer P. (org.). Física ainda é cultura? São Paulo: Livraria da Física, 2009.

MARX, Karl. Teses sobre Feuerbach. In: MARX, Karl; ENGELS, Friedrich. A ideologia alemã $(I-F e u e r b a c h) .11^{a}$ ed. São Paulo: Hucitec, 1999.

MARX, Karl; ENGELS, Friedrich. A ideologia alemã (I - Feuerbach). $11^{\text {a }}$ ed. São Paulo: Hucitec, 1999.

MATTOS, Cristiano Rodrigues de. O ABC da Ciência. In: GARCIA, N.M.D. et al (orgs). A Pesquisa em Ensino de Física e a Sala de Aula: Articulações Necessárias. São Paulo, Editora da Sociedade Brasileira de Física, 2010.

MENDONÇA, Lêda Glicério. A literatura de ficção científica como estratégia de ensino: discussão da ética profissional e do saber-fazer da ciência em sala de aula. Revista Ciências \& Ideias. N.1, Vol. 1- OUTUBRO/MARÇO 2009-2010.

MENEZES, Luis Carlos de. Ensino de física: reforma ou revolução? In: MARTINS, André Ferrer P. (org.). Física ainda é cultura? São Paulo: Livraria da Física, 2009.

MIRÓ. Poema sem título. In: Poemas. Edição da Associação Comunitária Monte Azul. São Paulo, s/d.

MONT'AlVÃO Jr., Arnaldo Pinheiro. As definições de ficção científica da crítica brasileira contemporânea. ESTUDOS LINGUÍSTICOS, São Paulo, 38 (3): 381-393, set.-dez. 2009.

MONTEIRO, Jeronymo. Tangentes da Realidade. São Paulo: Livraria 4 artes, 1969.

MOORE, Alan; GIBBONS, Dave. Watchmen. São Paulo: Ed. Abril, 1999.

MORAES, João Carlos Quartim de. "City” e as Limitações Ideológicas do Science-Fiction. Revista Civilização Brasileira. Ano I, n 7, maio 1966, pp. 173-188.

MORANU, Jeremias. Dossiê Brasil Sideral. In: CULT - Revista Brasileira de Literatura. N. $6-\mathrm{jan} / 1998$.

NÁDER, Alexandre Antônio Gíli. Física ainda - e sempre - é cultura. In: MARTINS, André Ferrer P. (org.). Física ainda é cultura? São Paulo: Livraria da Física, 2009.

NEVES, Marcos Cesar Danhoni; CARDOSO, Fabiano César; SAKAI, Fábio Sussumu, VERONEZE, Paulo Robert; ANDRADE, Acácio; BERNABÉ, Hilton Souza. Science fiction in physics teaching: improvement of science education and History of Science via informal strategies of teaching. Revista Ciências Exatas e Naturais, Ano 1, n 2, Jan/Jun 2000. pp. 91-101.

NIETZSCHE, Friedrich. Escritos sobre Educação. Rio de Janeiro: Ed. PUC-Rio; São Paulo: Loyola, 2003.

NISHITANI, Eduardo Yoshikazu; SILVA, Marcelo de Souza. Filmes de ficção científica nas escolas: instrumentos de sensibilização à ética planetária. II Fórum Ambiental da Alta Paulista. Tupã. 2006. 
NIXON, D. M. A Possibilidade de Matrix. In: IRWIN, William. Matrix: Bem-vindo ao deserto do real. Coletânea de William Irwin. São Paulo: Madras, 2003.

NOVAES, Adauto. A invenção das crenças. In: Projeto Cultura e Pensamento do Ministério da Cultura. Ciclo Mutações - a invenção das crenças. 2010. Programa em pdf disponível em: <http://www.sescsp.org.br/>. Acesso em 22/07/2010.

OLIVEIRA, Adalberto Anderlini; ZANETIC, João. Critérios para analisar e levar para a escola a ficção científica. In: ENCONTRO DE PESQUISA EM ENSINO DE FÍSICA, 9., 2008, Curitiba.

OLIVEIRA, Bernardo Jefferson. Cinema e imaginário científico. História, Ciências, Saúde - Manguinhos, Rio de Janeiro, v. 13 (suplemento), p. 133-50, outubro 2006. (org). História da Ciência no Cinema. Belo Horizonte: Argvmentvm, 2005. (org). História da Ciência no Cinema 2. Belo Horizonte: Argvmentvm, 2007.

OLIVEIRA, Luciano Denardin de. Aprendendo Física com o Homem-Aranha: Utilizando cenas do filme para discutir conceitos de Física no Ensino Médio. Física na Escola, v. 7, n. 2, 2006.

ORWELL, George. 1984. 17ª ed. São Paulo: Ed. Nacional, 1984.

OTERO, Léo Godoy. Introdução a uma história da ficção científica. São Paulo: Lua Nova, 1987.

PALACIOS, Sergio L. El cine de ciencia ficción como herramienta didáctica en la enseñanza de la física. In: I Jornadas de Innovación docente de la EUITIO (E.U. de Ingeniería Técnica en Informática de Oviedo). Oviedo. 19 e 20/out/2005. pp. 17-21. Texto em pdf disponível em <fisicacf.blogspot.com>. Acesso em 27/07/2010.

. El cine y la literatura de ciencia ficción como herramientas didácticas en la enseñanza de la física: una experiencia en el aula. Revista Eureka sobre Enseñanza y Divulgación de las Ciencias (2007), Vol. 4, № 1, pp. 106-122.

PEASE, Anastasia. Teaching Ethics with Science Fiction: A Case Study Syllabus. Union College, 2009. Arquivo em pdf disponível em <www.union.edu〉. Acesso em: 27/07/2010.

PEDROCHI, Franciana; MAEDA, Iris Antonio; ZAN, Kleto Michel; PHILIPPSEN, Gisele Strieder; SIMONETTI, Gustavo Max Dearo; ANDERSON, Ernani; SATO, Francielle; LIMA, David Clístenes Furoni de; CAMARGO, Sabrina; ANDRADE, Marcelo Freitas de; OLIVEIRA, Tatiane Cristina de; SANCHES, Mônica Bordim; NEVES, Marcos Cesar Danhoni. O uso de filmes de ficção científica: heróis e monstros no ensino de física. Arq. Apadec, 5(2): jul. dez.,2001.

PESSOA, Fernando. O eu profundo e os outros eus. Rio de Janeiro: Nova Fronteira, 1999.

Poesia 1902 - 1917. São Paulo: Companhia das Letras, 2006.

PIASSI, Luís P. C. Contatos: A ficção científica no ensino de ciências em um contexto sócio cultural. 2007. 453p. Tese (Doutorado) - Faculdade de Educação, Universidade de São Paulo, São Paulo, 2007.

PIASSI, Luís P. C.; PIETROCOLA, Maurício. De Olho no Futuro: Ficção Científica para Debater Questões Sociopolíticas de Ciência e Tecnologia em Sala de Aula. Ciência \& Ensino, vol. 1, número especial, novembro de 2007a. 
. Ficção científica e ensino de ciências: para além do método de 'encontrar erros em filmes'. Educação e Pesquisa, São Paulo, v.35, n.3, p. 525-540, set./dez. 2009.

. Ficção Científica no Ensino de Física: utilizando um Romance para Desenvolver Conceitos. XVI Simpósio Nacional de Ensino de Física. Rio de Janeiro: CEFET-RJ, 2005.

. Possibilidade dos Filmes de Ficção Científica como Recurso Didático em Aulas de Física: a Construção de um Instrumento de Análise. X Encontro de Pesquisa em Ensino de Física: Londrina, 2006.

Primeiro Contato: Ficção Científica para Abordar os Limites do Conhecido em Sala de Aula. XVII Simpósio Nacional de Ensino de Física: São Luiz, 2007b.

Quem Conta um Conto Aumenta um Ponto Também em Física: Contos de Ficção Científica em Sala de Aula. XVII Simpósio Nacional de Ensino de Física: São Luiz, 2007c.

. Questões Socio-Políticas de Ciência através da Ficção Científica: um Exemplo com "Contato". XI Encontro de Pesquisa em Ensino de Física: Curitiba, 2008.

PIASSI, Luís P. C.; SANTOS, Emerson I.; VIEIRA, Rui M. B. Ambientes Urbanos do Futuro: Abordando Questões Sócio-Ambientais em Sala de Aula através da Ficção Científica. Encontro Nacional de Ensino de Ciências da Saúde e do Ambiente: UNIPLI, Niterói/RJ, 2008.

POPPER, Karl. A lógica da pesquisa científica. São Paulo: Pensamento-Cultrix, 2006.

RABKIN, Eric. The Fantastic in Literature. New Jersey: Princenton University, 1977.

RAHAM, Gary. Teaching science fact with science fiction. Portsmouth (New Hampshire, USA): Teacher Ideas Press, 2004.

REGAZZONI, Simone. A filosofia de Lost. Rio de Janeiro: Best Seller, 2009.

REIS, Pedro; GALVÃO, Cecília. O diagnóstico de concepções sobre os cientistas através da análise e discussão de histórias de ficção científica redigidas pelos alunos. Revista Electrónica de Enseñanza de las Ciencias Vol. 5, № 2 (2006).

RETAMOSA, Carmen Guerra. Náufragos, amantes y aventureros en el aula. Revista Eureka sobre Enseñanza y Divulgación de las Ciencias (2005), Vol. 2, № 2, pp. 173 182.

ROCCA, Rosana Amici Della; CURI, Denise. Química: módulo 6. Apostila da Secretaria de Estado da Educação de São Paulo. MARCONDES, Maria Eunice Ribeiro; GIORDAN, Marcelo (Orgs.). São Paulo: Dreampix Comunicação, s/d.

ROWLANDS, Mark. Scifi=scifilo: a filosofia explicada pelos filmes de ficção científica. Rio de Janeiro: Relume, 2005.

RUY, Mateus Cazelato. O conceito de jogos de linguagem nas Investigações Filosóficas de Wittgenstein. In: SEMINÁRIO DE PESQUISA EM CIÊNCIAS HUMANAS, 7., 2008, Londrina. Anais... Londrina: Eduel, 2008. Disponível na Internet via WWW. URL: http://www2.uel.br/eventos/sepech/anais_capa.htm. Arquivo capturado em 11 de janeiro de 2010.

SCAVONE, Rubens Teixeira. O diálogo dos mundos. São Paulo: Clube do livro, 1965. 
SCHICK Jr., Theodore. Destino, Liberdade e Pré-Conhecimento. In: IRWIN, William. Matrix: Bem-vindo ao deserto do real. Coletânea de William Irwin. São Paulo: Madras, 2003.

SCHOEREDER, Gilberto. Ficção Científica. Rio de Janeiro: Francisco Alves, 1986.

SCHWARTZ, Joseph. O Momento Criativo - Mito e Alienação na Ciência Moderna. São Paulo: Best Seller, 1992.

SHELLEY, Mary. Frankenstein. São Paulo: Martin Claret, 2005.

SILVA, Alexander Meireles da. O admirável mundo novo da República Velha: o nascimento da ficção científica brasileira no começo do século XX. Rio de Janeiro: UFRJ, Faculdade de Letras, 2008. Tese de Doutorado em Literatura Comparada. 193 p.

SILVA, Luciene de Fátima; FERREIRA, Rodolfo Aquiles Fortunato; MENDONÇA, Cláudio Pires de; ANDRADE, José Maurício de. A física nos filmes de ficção científica: uma proposta de motivação para o estudo de física. XVI Simpósio Nacional de Ensino de Física. CEFET-RJ, Rio de Janeiro, 2005.

SIMON, Anne. A verdadeira ciência por trás do Arquivo X. São Paulo: Mercuryo, 2000.

SODRÉ, Muniz. A ficção do tempo: análise da narrativa de science fiction. Petrópolis: Vozes, 1973.

STEINER, Rudolf. A arte da educação - I: o estudo geral do homem, uma base para a pedagogia. $4^{\text {a }}$ ed. São Paulo: Antroposófica, 2007.

. A arte da educação - II: metodologia e didática. $2^{\text {a }}$ ed. (2003). São Paulo: Antroposófica, reimpressão 2009.

. A arte da educação - III: discussões pedagógicas. São Paulo: Antroposófica, 1999.

. A filosofia da liberdade: fundamentos para um filosofia moderna. $4^{\mathrm{a}}$ ed. São Paulo: Antroposófica, 2000.

- O método cognitivo de Goethe: linhas básicas para uma gnosiologia da cosmovisão goethiana. $2^{\mathrm{a}}$ ed. São Paulo: Antroposófica, 2004.

Pedagogia, arte e moral. $1^{\text {a }}$ ed. São Paulo: João de Barro, 2008.

. Teosofia: introdução ao conhecimento supra-sensível do mundo e do destino humano. $7^{\text {a }}$ ed. São Paulo: Antroposófica, 2004.

. Verdade e ciência: prelúdio a uma "Filosofia da Liberdade". São Paulo: Antroposófica, 1985.

STEPHENS, William O. Estoicismo nas estrelas: Yoda, o Imperador, e a Força. In: IRWIN, William (Coord.). Guerra nas estrelas e a filosofia: mais poderoso do que você imagina. Coletânea de Kevin S. Decker e Jason T. Eberl. São Paulo: Madras, 2005.

SUVIN, Darko. Metamorfosis de la ciencia ficción: sobre la poética y la história de um género literario. Cidade do México: Fondo de Cultura Económica, 1984.

TAVARES, Bráulio. O que é ficção científica. $2^{\mathrm{a}}$ ed. Coleção Primeiros Passos, 169. São Paulo: Brasiliense, 1992. 
TREVISAN, Helena Maria Ferreira; LIMA, Patrícia T. de Oliveira (col.); MASCARENHAS, Ana Angélica A. Filhos felizes na escola - Pedagogia Waldorf, o ensino pela arte. São Paulo: Trevisan Editora Universitária, 2006.

VERNE, Jules. Twenty Thousand Leagues under the Sea. London: Penguin Books, 1994. Viagem ao redor da Lua. São Paulo: Artes Gráficas Bisordi, 1972.

VYGOTSKY, Lev Semyonovich. [Michael Cole et al. (orgs)]. A formação social da mente: o desenvolvimento dos processos psicológicos superiores. $5^{\mathrm{a}}$ ed. São Paulo: Martins Fontes, 1994.

. Pensamento e linguagem. $2^{\text {a }}$ ed. São Paulo: Martins Fontes, 1998.

WELLS, Herbert George. A máquina do tempo. Rio de Janeiro: Francisco Alves, 1991. O homem invisível. Rio de Janeiro: Francisco Alves, 1985.

WITTGENSTEIN, Ludwig J. J. Investigações Filosóficas. Coleção Os Pensadores. São Paulo: Nova Cultural, 1999.

WUKMIR, Jorge (Seleção dos trabalhos). Ciência e mitos. Rio de Janeiro: Ed. Fundação Getúlio Vargas, 1975.

YAGUELLO, Marina. Introdução. In. BAKHTIN, Mikhail M. (V. N. Volochínov). Marxismo e filosofia da linguagem : problemas fundamentais do método sociológico da linguagem. 12a ed. São Paulo: Hucitec, 2006.

YEFFETH, Glenn (org.). A Pílula Vermelha: Questões de Ciência, Filosofia e Religião em Matrix. São Paulo: PubliFolha. 2003.

ZAMIATIN, Eugene. Nós. Rio de Janeiro: Anima, 1983.

ZANETIC, João. Física ainda é cultura! In: MARTINS, André Ferrer P. (org.). Física ainda é cultura? São Paulo: Livraria da Física, 2009.

. Física e Cultura. Ciência e Cultura. Ano 57 - número 3 - julho/agosto/setembro de 2005.

. Física também é cultura. Tese (Doutorado em Educação) - Faculdade de Educação, Universidade de São Paulo, São Paulo, 1989.

. Notas de aula de Evolução dos Conceitos da Física. São Paulo; Instituto de Física da Universidade de São Paulo, 2006.

ZIZEK, Slavoj. Matrix: ou os Dois Lados da Perversão. In: IRWIN, William. Matrix: Bem-vindo ao deserto do real. Coletânea de William Irwin. São Paulo: Madras, 2003. 


\section{FILMES, MÚSICAS E SÉRIES}

2001 - UMA ODISSÉIA NO ESPAÇO. Direção: Stanley Kubrick. Roteiro: Arthur C. Clarke e Stanley Kubrick. Produção: Stanley Kubrick. Intérpretes: Keir Dullea, Gary Lockwood e outros. MGM/Polaris, 1968. 1 DVD (149 min).

ANIMATRIX. Produzido por: Larry e Andy Wachowski. Warner Bros. Pictures \& Village Roadshow Films. [Vídeolar S/A], 2003. 1 DVD (94 min).

ANTUNES, Arnaldo; BRITTO, Sérgio; FROMER, Marcelo. Comida. In: TITÃS. Jesus não tem dente no país dos banguelas. WEA, 1987. 1 CD. Faixa 2.

BATTLESTAR GALLACTICA: Season Four. Direção: Michael Rymer, Anthony Hemingway e outros. Roteiro: Ronald Dowl Moore, e outros. Produção: Ronald Dowl Moore e outros. Intérpretes: Edward James Olmos, Mary McDonnell e outros. Universal Pictures, 2008. 4 DVDs (490 min).

BLADE RUNNER - O Caçador de Andróides. Direção: Ridley Scott. Roteiro: Hampton Fancher e David Peoples. Produção: Brian Kelly e Hampton Fancher. Intérpretes: Harrison Ford, Rutger Hauer e outros. Warner Bros, 1982. 1 DVD (116 min).

BUARQUE, Chico. A Banda. In: Chico Buarque de Holanda. RGE, 1966, 1 CD. Faixa 1.

CAZUZA; FREJAT, Roberto. Ideologia. In: CAZUZA. Ideologia. PolyGram, 1988, 1 CD. Faixa 1.

CONTATOS IMEDIATOS DO TERCEIRO GRAU. Direção e Roteiro: Steven Spielberg. Produção: Julia Phillips e Michael Phillips. Intérpretes: Richard Dreyfuss, François Truffaut e outros. Distribuição: Columbia Pictures/Sony Pictures Releasing, 1977. 1 DVD (132 min).

E.T. - O Extraterrestre. Direção: Steven Spielberg. Roteiro: Melissa Mathison. Produção: Steven Spielberg e Kathleen Kennedy. Intérpretes: Henry Thomas, Peter Coyote, Drew Barrymore e outros. Distribuição: Universal Pictures, 1982. 1 DVD (115 min).

FILHOS DA ESPERANÇA. Direção: Alfonso Cuarón. Roteiro: Alfonso Cuarón e Timothy J. Sexton. Produção: Marc Abraham, Eric Newman e outros. Intérpretes: Clive Owen, Julianne Moore e outros. Universal Pictures, 2006. 1 DVD (109 min).

GIL, Gilberto; ANTUNES, Arnaldo. A ciência em si. In: GIL, Gilberto. Quanta. Warner Music, 1997, 2 CD. Faixa 14.

MATRIX. Direção e Roteiro: Larry e Andy Wachowski. Produção: Joel Silver. Intérpretes: Keanu Reeves, Laurence Fishburne e outros. Warner Bros. Pictures \& Village Roadshow Films. [Vídeolar S/A], 1999. 1 DVD (136 min).

MATRIX RELOADED. Direção e Roteiro: Larry e Andy Wachowski. Produção: Joel Silver. Intérpretes: Keanu Reeves, Laurence Fishburne e outros. Warner Bros. Pictures \& Village Roadshow Films. [Vídeolar S/A], 2003. 1 DVD (138 min).

MATRIX REVOLUTIONS. Direção e Roteiro: Larry e Andy Wachowski. Produção: Joel Silver. Intérpretes: Keanu Reeves, Laurence Fishburne e outros. Warner Bros Pictures \& Village Roadshow Films [Vídeolar S/A], 2003. 1DVD (129 min).

METROPOLIS. Direção: Fritz Lang. Roteiro: Thea Von Harbou e Fritz Lang. Produção: Erich Pommer. Intérpretes: Alfred Abel, Brigitte Helm e outros. Distribuição: UFA (Alemanha) e Paramount Pictures (EUA), 1927. (153 min). 
O ENIGMA DE KASPER HAUSER Direção: Werner Herzog. Intérpretes: Bruno S., Brigitte Mira, Walter Ladengast e outros. Distribuição: Versátil Home Video, 1974. 1 DVD (109 min).

O HOMEM COM DOIS CÉREBROS. Direção: Carl Reiner. Roteiro: George Gipe e Steve Martin. Intérpretes: Steve Martin, Kathleen Turner e outros. Warner Bros, 1983. 1DVD (93min).

RAMALHO, Zé. Admirável Gado Novo. In: Zé Ramalho 2. Epic (CBS - Sony Music), 1980, 1 CD. Faixa 2.

RUSSO, Renato. Música Urbana 2. In: Legião Urbana. Dois. EMI Music, 1986, 1 CD. Faixa 9.

THE WALL. Direção: Alan Parker. Roteiro: Roger Waters. Produção: Alan Marshall. Intérpretes: Bob Geldof, Christine Hargreaves e outros. Metro-Goldwyn Mayer, 1982. 1 DVD (99 min).

VERTIGO. Direção: Alfred Hitchcock. Roteiro: Alec Coppel, Samuel A. Taylor e BoileauNarcejac. Produção: Alfred Hitchcock. Intérpretes: James Stewart, Kim Novak e outros. Paramount Pictures (EUA), 1958. (128 min).

YUKA, Marcelo. Minha alma (A paz que eu não quero). In: O Rappa. Lado B Lado A. Warner Music, 1999, 1 CD., Faixa 06. 